\title{
A Precipitation-Runoff Model for the Blackstone River Basin, Massachusetts and Rhode Island
}

By Jeffrey R. Barbaro and Phillip J. Zarriello

Prepared in cooperation with the

Rhode Island Water Resources Board

Scientific Investigations Report 2006-5213 


\title{
U.S. Department of the Interior \\ DIRK KEMPTHORNE, Secretary
}

\section{U.S. Geological Survey \\ P. Patrick Leahy, Acting Director}

U.S. Geological Survey, Reston, Virginia: 2007

\author{
For sale by U.S. Geological Survey, Information Services \\ Box 25286, Denver Federal Center \\ Denver, CO 80225 \\ For more information about the USGS and its products: \\ Telephone: 1-888-ASK-USGS \\ World Wide Web: http://www.usgs.gov/
}

\author{
Any use of trade, product, or firm names in this publication is for descriptive purposes only and does not imply \\ endorsement by the U.S. Government. \\ Although this report is in the public domain, permission must be secured from the individual copyright owners to \\ reproduce any copyrighted materials contained within this report. \\ Suggested citation: \\ Barbaro, J.R., and Zarriello, P.J., 2007, A precipitation-runoff model for the Blackstone River Basin, Massachusetts \\ and Rhode Island: U.S. Geological Survey Scientific Investigations Report 2006-5213, 95 p.
}




\section{Contents}

Abstract

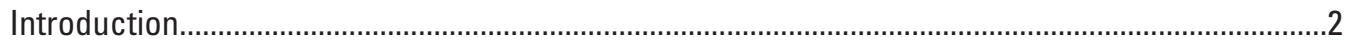

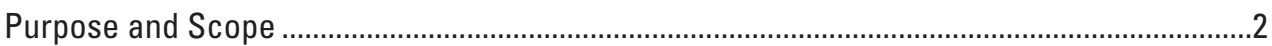

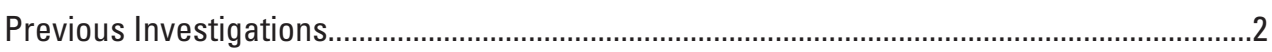

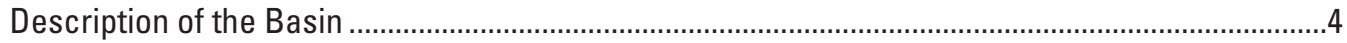

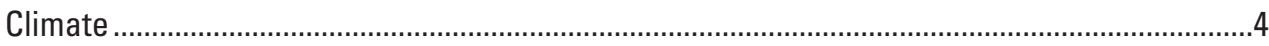

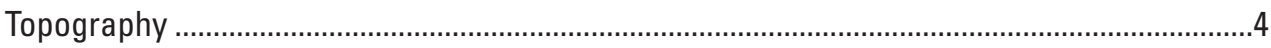

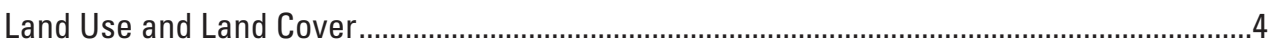

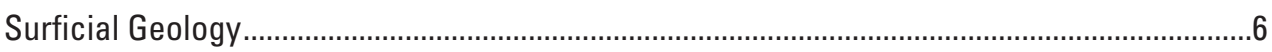

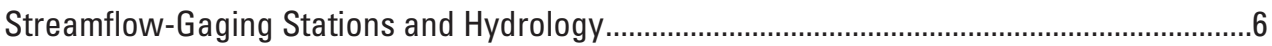

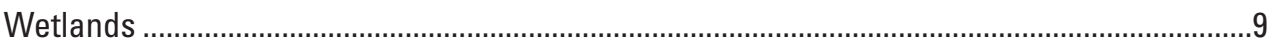

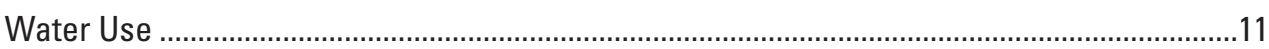

Precipitation-Runoff Model for the Blackstone River Basin ...........................................................11

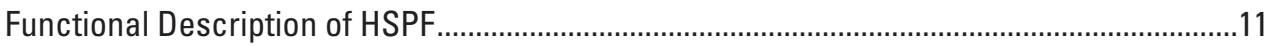

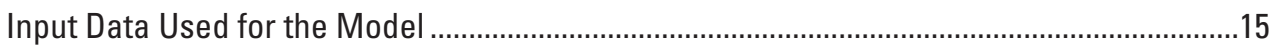

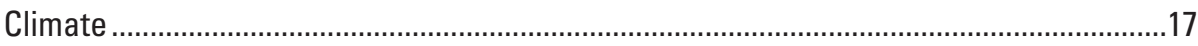

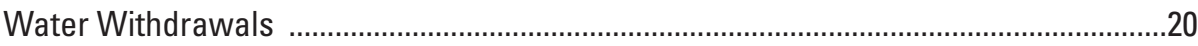

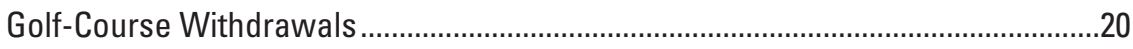

Streamflow Depletion by Ground-Water Withdrawals .........................................25

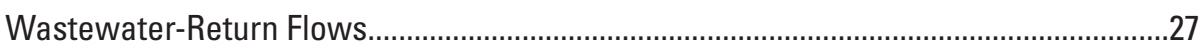

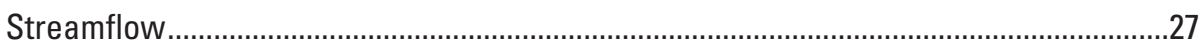

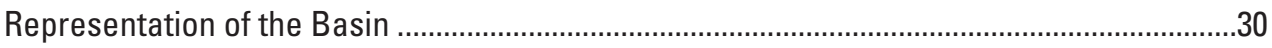

Data Layer Processing and Basin Simplification .............................................................31

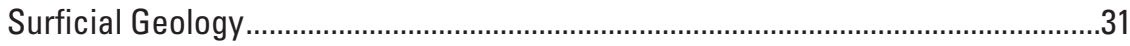

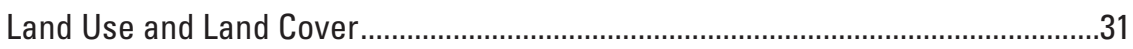

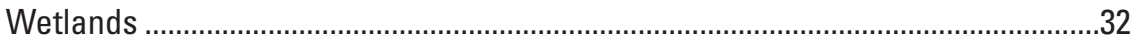

Public Water and Public Sewer Systems …………………...................................32

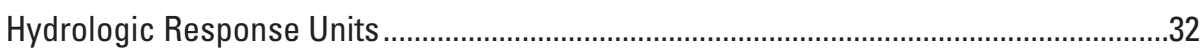

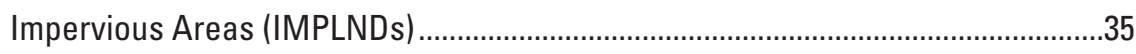

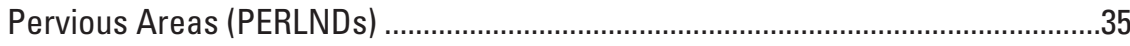

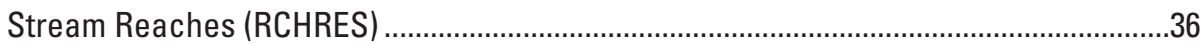

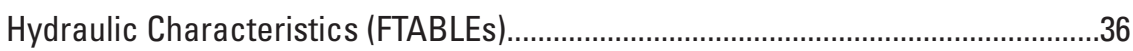

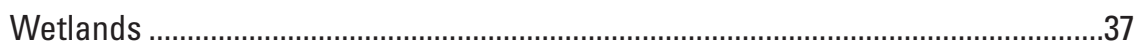

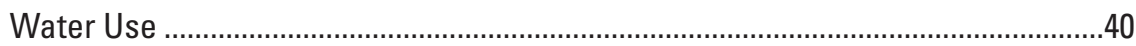

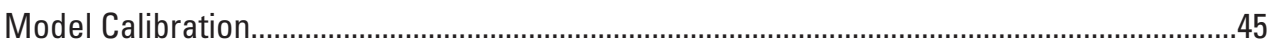

Annual and Monthly Mean Discharge ........................................................................47

Daily Mean Discharge ........................................................................................52

Simulated Hydrologic Response Unit Water Budgets...................................................52

Summary of Anthropogenic Water Use in Basin............................................................61

Sensitivity of Model Results to Changes in Values of Parameters ................................66

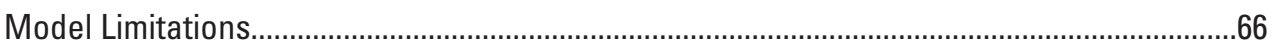

Summary

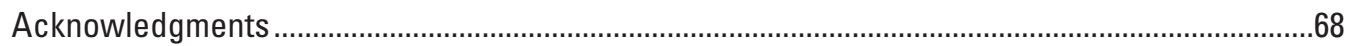

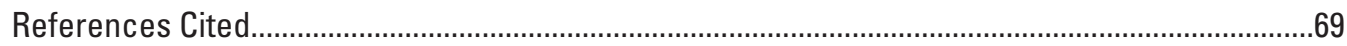

Appendix 1. Hydrological Simulation Program-FORTRAN User Control File Input for

Pervious and Impervious Area Parameters........................................................................73 


\section{Figures}

1-6. Maps Showing-

1. The Blackstone River Basin, towns, and climatological stations used to simulate streamflow, Massachusetts and Rhode Island .......................................................

2. Land use in the Blackstone River Basin ............................................................. 5

3. Surficial geology in the Blackstone River Basin ...................................................

4. Streamflow-gaging stations in the Blackstone River Basin and

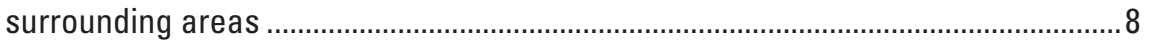

5. Wetlands in the Blackstone River Basin ............................................................ 10

6. Distribution of public water and public sewer systems in the Blackstone River Basin. 14

7. Schematic diagram of inflows and outflows to a Hydrological Simulation ProgramFORTRAN stream reach.

8-9. Maps Showing-

8. Model reaches, subbasin boundaries, and the boundary between climatological zones for the Hydrological Simulation Program-FORTRAN (HSPF) model for the Blackstone River Basin.

9. Locations of water withdrawals, transfers, and wastewater returns in the Blackstone River Basin.

10. Graph showing daily withdrawal rate at King's Grant Water Company Well 1, North

Attleboro, Massachusetts, 1996-2001, and calculated streamflow depletion.................26

11. Diagram showing areas of hydrologic response units, wetlands, and open water as percentages of drainage area....................................................................................3

12. Map showing water-supply reservoirs in the Blackstone River Basin ..........................42

13-24. Graphs Showing-

13. Relation between simulated and observed or computed annual mean discharge at streamflow-gaging stations $A$, Quinsigamond River at North Grafton, Mass. (QU1A, 01110000); B, Blackstone River at Millbury, Mass. (BL2B, 01109730); $C$, Nipmuc River near Harrisville, R.I. (NI1A, 01111300); D, Branch River at Forestdale, R.I. (BR2A, 01111500); E, Blackstone River at Woonsocket, R.I. (BL9A, 01112500); and F, Blackstone River at Pawtucket, R.I. (BL13, 01113895) .....50

14. Relation between simulated and observed or computed monthly mean discharge at streamflow-gaging stations A, Quinsigamond River at North Grafton, Mass. (QU1A, 01110000); B, Blackstone River at Millbury, Mass. (BL2B, 01109730); C, Nipmuc River near Harrisville, R.I. (NI1A, 01111300); D, Branch River at Forestdale, R.I. (BR2A, 01111500); E, Blackstone River at Woonsocket, R.I. (BL9A, 01112500); and F, Blackstone River at Pawtucket, R.I. (BL13, 01113895). 51

15. Daily precipitation at Worcester Regional Airport, Worcester, Mass. (KORH), and T.F. Green Regional Airport, Warwick, R.I. (KPVD), and simulated and observed or computed daily mean discharge at streamflow-gaging stations $A$, Quinsigamond River at North Grafton, Mass. (QU1A, 01110000); $B$, Blackstone River at Millbury, Mass. (BL2B, 01109730); C, Nipmuc River near Harrisville, R.I. (NI1A, 01111300); $D$, Branch River at Forestdale, R.I. (BR2A, 01111500); E, Blackstone River at Woonsocket, RI (BL9A, 01112500); and F, Blackstone River at Pawtucket, R.I. (BL13, 01113895)...

16. Relations between simulated and observed or computed daily mean discharge at streamflow-gaging stations $A$, Quinsigamond River at North Grafton, Mass. (QU1A, 01110000); B, Blackstone River at Millbury, Mass. (BL2B, 01109730); C. Nipmuc River near Harrisville, R.I. (NI1A, 01111300); D, Branch River at Forestdale, R.I. (BR2A, 01111500); E, Blackstone River at Woonsocket, R.I. (BL9A, 01112500); and F, Blackstone River at Pawtucket, R.I. (BL13, 01113895) .....56 
13-24. Graphs Showing - Continued

17. Flow-duration curves for simulated and observed or computed daily mean discharges at streamflow-gaging stations $A$, Quinsigamond River at North Grafton, Mass. (QU1A, 01110000); B, Blackstone River at Millbury, Mass. (BL2B, 01109730); C, Nipmuc River near Harrisville, R.I. (NI1A, 01111300); $D$, Branch River at Forestdale, R.I. (BR2A, 01111500); E, Blackstone River at Woonsocket, R.I. (BL9A, 01112500); and F, Blackstone River at Pawtucket, R.I. (BL13, 01113895) .

18. Mean annual water budget by component for 1997-2001 for each hydrologic response unit simulated by the Hydrological Simulation ProgramFORTRAN model of the Blackstone River Basin, in inches $A$, per acre; and $B$, over the entire basin. 58

19. A wet month (March 2001) water budget for each hydrologic response unit simulated by the Hydrological Simulation Program-FORTRAN model of the Blackstone River Basin, in inches $A$, per acre for moisture supply, total runoff to streams, and total losses to evapotranspiration; $B$, per acre for individual components of runoff to streams and losses to evapotranspiration and sewers; and $C$, over the entire basin for individual components of runoff to streams and losses to evapotranspiration and sewers.

20. A dry month (September 1998) water budget for each hydrologic response unit simulated by the Hydrological Simulation Program-FORTRAN model of the Blackstone River Basin, in inches $A$, per acre for moisture supply, total runoff to streams and total losses to evapotranspiration; $B$, per acre for individual components of runoff to streams and losses to evapotranspiration and sewers; and $C$, over the entire basin for individual components of runoff to streams and osses to evapotranspiration and sewers

21. The mean monthly water budget for 1997-2001 for PERLND 3 (forest overlying till) simulated by the Hydrological Simulation Program-FORTRAN model of the Blackstone River Basin model, in inches $A$, per acre for moisture supply, total runoff to streams and total losses to evapotranspiration; and $B$, per acre for individual components of runoff to streams and losses to evapotranspiration......62

22. The mean monthly water budget for 1997-2001 for PERLND 11 (forest overlying sand and gravel) simulated by the Hydrological Simulation Program-FORTRAN model of the Blackstone River Basin, in inches $A$, per acre for moisture supply, total runoff to streams and total losses to evapotranspiration; and $B$, per acre for individual components of runoff to streams and losses to evapotranspiration......63

23. The mean monthly water budget for 1997-2001 for PERLND 4 (medium- to lowdensity residential areas with no import or export of water overlying till) simulated by the Hydrological Simulation Program-FORTRAN model of the Blackstone River Basin, in inches $A$, per acre for moisture supply, total runoff to streams and total losses to evapotranspiration; and $B$, per acre for individual components of runoff to streams and losses to evapotranspiration and sewers.

24. The mean monthly water budget for 1997-2001 for PERLND 1 (commercialindustrial-transportation areas) simulated by the Hydrological Simulation Program-FORTRAN model of the Blackstone River Basin, in inches $A$, per acre for moisture supply, total runoff to streams, and total losses to evapotranspiration; and $B$, per acre for individual components of runoff to streams and losses to evapotranspiration and sewers 


\section{Tables}

1. Streamflow-gaging stations in the Blackstone River Basin, Massachusetts and Rhode Island.

2. Summary of water use by town in the Blackstone River Basin, Massachusetts and Rhode Island.

3. Organization and description of Dataset Numbers in the Watershed Data Management file for the Hydrological Simulation Program-FORTRAN model of the Blackstone River Basin, Massachusetts and Rhode Island

4. Constituent attributes (IDCONs) for the Watershed Data Management file of the Hydrological Simulation Program-FORTRAN model of the Blackstone River Basin, Massachusetts and Rhode Island.

5. Municipal, commercial/industrial, and golf-course withdrawals in the Blackstone River Basin, Massachusetts and Rhode Island...

6. Wastewater-return flows in the Blackstone River Basin, Massachusetts and Rhode Island....

7. Summary of relations between daily mean streamflow at the partial-record streamflow-gaging stations and at the continuous-record stations used to compute continuous streamflow records at the partial-record stations for 1997-2001, Blackstone River Basin, Massachusetts and Rhode Island ...

8. Residential densities used in the Hydrological Simulation Program-FORTRAN model of the Blackstone River Basin, Massachusetts and Rhode Island

9. Definitions and areas of hydrologic response units (HRUs), wetlands, and open water used to represent the Blackstone River Basin, Massachusetts and Rhode Island

10. Effective impervious area by developed land-use type for the Hydrological Simulation Program-FORTRAN model of the Blackstone River Basin,

Massachusetts and Rhode Island

11. Descriptions of stream reaches in the Hydrological Simulation ProgramFORTRAN model of the Blackstone River Basin, Massachusetts and Rhode Island

12. Summary of monthly model-fit statistics for flows simulated by the Hydrological Simulation Program-FORTRAN model and observed or computed flows at 15 streamflow-gaging stations in the Blackstone River Basin, Massachusetts and Rhode Island, January 1997 through December 2001

13. Summary of daily model-fit statistics for flows simulated by the Hydrological Simulation Program-Fortran model and observed or computed flows at 15 streamflow-gaging stations in the Blackstone River Basin, Massachusetts and Rhode Island, January 1997 through December 2001

14. Summary of model-fit statistics computed by the HSPEXP program for flows simulated by the Hydrological Simulation Program-FORTRAN model and observed or computed flows at 15 streamflow-gaging stations in the Blackstone River Basin, Massachusetts and Rhode Island, January 1997 through December 2001......49 


\section{Conversion Factors}

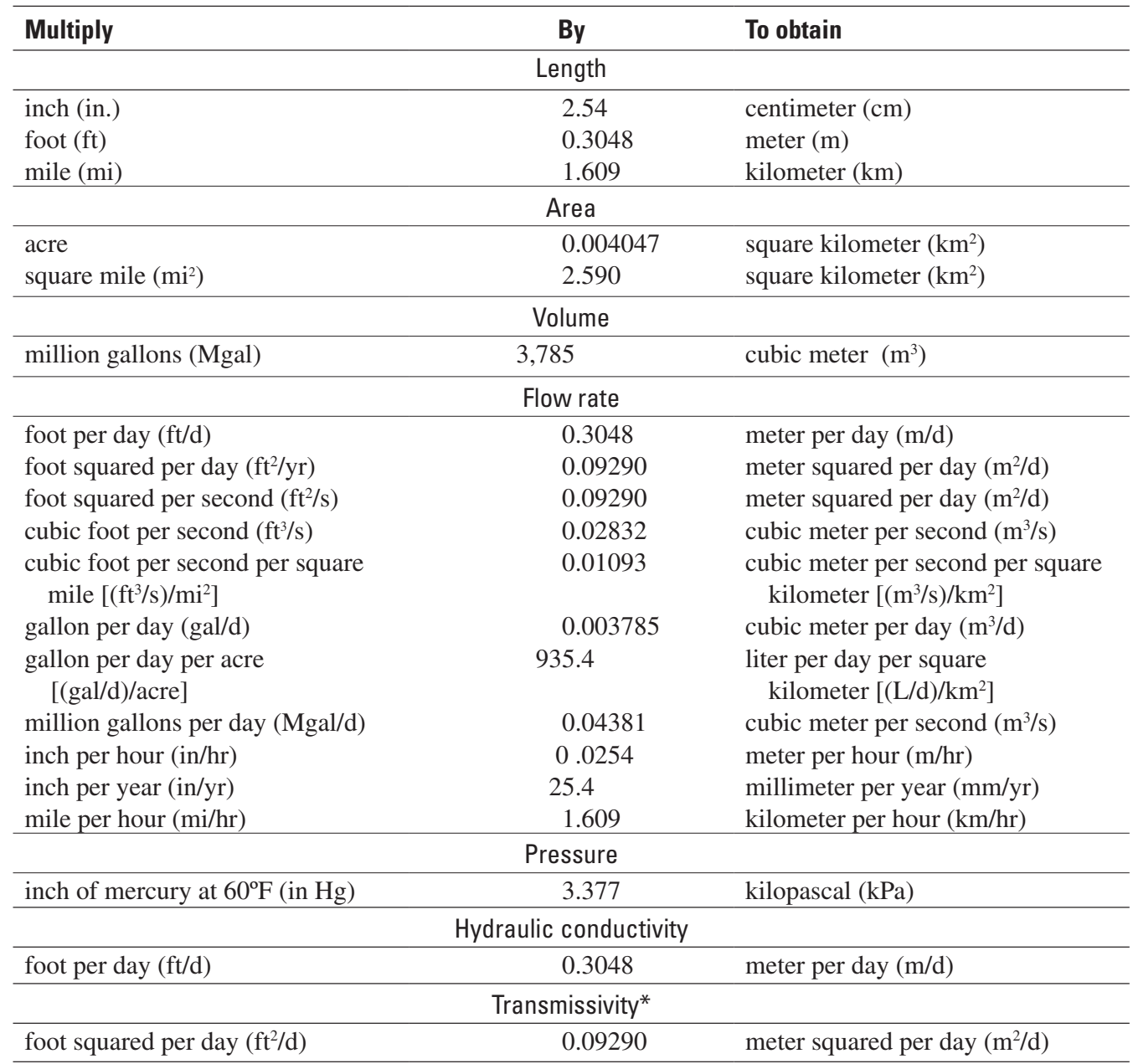

Temperature in degrees Celsius $\left({ }^{\circ} \mathrm{C}\right)$ may be converted to degrees Fahrenheit $\left({ }^{\circ} \mathrm{F}\right)$ as follows:

$$
{ }^{\circ} \mathrm{F}=\left(1.8 \times^{\circ} \mathrm{C}\right)+32
$$

Temperature in degrees Fahrenheit $\left({ }^{\circ} \mathrm{F}\right)$ may be converted to degrees Celsius $\left({ }^{\circ} \mathrm{C}\right)$ as follows:

$$
{ }^{\circ} \mathrm{C}=\left({ }^{\circ} \mathrm{F}-32\right) / 1.8
$$

Vertical coordinate information is referenced to the North American Vertical Datum of 1988 (NAVD 88).

Horizontal coordinate information is referenced to the North American Datum of 1983 (NAD 83), unless otherwise noted.

*Transmissivity: The standard unit for transmissivity is cubic foot per day per square foot times foot of aquifer thickness $\left[\left(\mathrm{ft}^{3} / \mathrm{d}\right) / \mathrm{ft}^{2}\right] \mathrm{ft}$. In this report, the mathematically reduced form, foot squared per day $\left(\mathrm{ft}^{2} / \mathrm{d}\right)$, is used for convenience. 


\section{Acronyms and Abbreviations}

BL2B Streamflow-gaging station on the Blackstone River at Millbury, Mass. (01109730)

BR2A Streamflow-gaging station on the Branch River at Forestdale, R.I. (01111500)

BL9A Streamflow-gaging station on the Blackstone River at Woonsocket, R.I. (01112500)

BL13 Streamflow-gaging station on the Blackstone River at Pawtucket, R.I. (01113895)

CGAP Channel Geometry Analysis software Program

DSN

Data Set Number associated with the Watershed Data Management database

FEMA Federal Emergency Management Agency

FTABLE Function table that defines the relation between depth, storage and discharge of water in a reach

GENFTBL GENerate FTaBLe software program

GENSCN GENerate SCeNarios software program

HRU Hydrologic response unit

HSPF Hydrologic Simulation Program-FORTRAN

HSPEXP Expert system for the HSPF model

IDCONS Constituent identification attribute associated with the Watershed Data Management database

IDLOCN Location identification attribute associated with the Watershed Data Management database

IDSCEN Scenario identification attribute associated with the Watershed Data Management database

IMPLND HSPF impervious-area land element

KORH Climatological station at Worcester Regional Airport, Worcester, Mass.

KPVD Climatological station at T.F. Green Regional Airport, Warwick, R.I.

LULC Land Use Land Cover

MFACT Multiplier used to adjust time-series data read from the Watershed Data Management database

MASSGIS Massachusetts Geographic Information System

MADEP Massachusetts Department of Environmental Protection

MOVE.1 Maintenance of Variance Extension, Type 1

NI1A Streamflow-gaging station on the Nipmuc River near Harrisville, R.I. (01111300)

PERLND HSPF pervious-area land element

PET Potential Evapotranspiration

PEST Parameter estimation software program

QU1A Streamflow-gaging station on the Quinsigamond River at North Grafton, Mass. (01110000)

RCHRES HSPF stream or reservoir reach

RIDEM Rhode Island Department of Environmental Management

RIWRB Rhode Island Water Resources Board

RIGIS Rhode Island Geographic Information System

STRMDEPL Analytical program to compute streamflow depletion from a pumped well

UCI HSPF user control input file

USGS U.S. Geological Survey

WDM Watershed Data Management database

WDMUtil Watershed Data Management Utility software

WMA Water Management Act 


\section{Acronyms for HSPF Model Parameters}

AGWO

AGWRC

AGWETP

CEPE

DEEPFR

IFWO

IGWI

INFILT

INTFW

IRC

IVOL

KVARY

LZET

LZETP

LZLI

LZSN

MON-IRC

MON-INTERCEP

MON-INTERFLW

MON-LZET

MON-UZSN

OUTDGT

OVOL

PERO

SURI

SURO

SUPY

UZET

UZSN
Active ground-water outflow from pervious areas

Active ground-water recession constant

Active ground-water evapotranspiration rate

Evapotranspiration losses from interception storage

Fraction of ground water that enters a deep flow system

Interflow outflow from pervious areas

Deep ground-water discharge

Infiltration rate

Interflow inflow parameter

Interflow recession constant

Inflow volume to a reach

Parameter that modifies the linearity of the active groundwater recession constant

Evapotranspiration losses from lower-zone storage

Lower-zone evapotranspiration parameter

Lower-zone lateral input

Lower-zone nominal storage

Monthly interflow recession constant

Monthly interception storage

Monthly interflow controls rate of flow from surface storage

Monthly lower zone evapotranspiration rate

Monthly upper zone nominal storage

Volume time series specified for a reach

Outflow volume from a reach

Total runoff from pervious areas

Surface-water runoff from impervious areas

Surface-water runoff from pervious areas

Moisture supply to pervious and impervious areas

Evapotranspiration losses from upper-zone storage

Upper zone nominal storage 



\title{
A Precipitation-Runoff Model for the Blackstone River Basin, Massachusetts and Rhode Island
}

\author{
By Jeffrey R. Barbaro and Phillip J. Zarriello
}

\section{Abstract}

A Hydrological Simulation Program-FORTRAN (HSPF) precipitation-runoff model of the Blackstone River Basin was developed and calibrated to study the effects of changing land- and water-use patterns on water resources. The $474.5 \mathrm{mi}^{2}$ Blackstone River Basin in southeastern Massachusetts and northern Rhode Island is experiencing rapid population and commercial growth throughout much of its area. This growth and the corresponding changes in land-use patterns are increasing stress on water resources and raising concerns about the future availability of water to meet residential and commercial needs. Increased withdrawals and wastewaterreturn flows also could adversely affect aquatic habitat, water quality, and the recreational value of the streams in the basin.

The Blackstone River Basin was represented by 19 hydrologic response units (HRUs): 17 types of pervious areas (PERLNDs) established from combinations of surficial geology, land-use categories, and the distribution of public water and public sewer systems, and two types of impervious areas (IMPLNDs). Wetlands were combined with open water and simulated as stream reaches that receive runoff from surrounding pervious and impervious areas. This approach was taken to achieve greater flexibility in calibrating evapotranspiration losses from wetlands during the growing season. The basin was segmented into 50 reaches (RCHRES) to represent junctions at tributaries, major lakes and reservoirs, and drainage areas to streamflow-gaging stations. Climatological, streamflow, waterwithdrawal, and wastewater-return data were collected during the study to develop the HSPF model. Climatological data collected at Worcester Regional Airport in Worcester, Massachusetts and T.F. Green Airport in Warwick, Rhode Island, were used for model calibration. A total of 15 streamflow-gaging stations were used in the calibration. Streamflow was measured at eight continuous-record streamflow-gaging stations that are part of the U.S. Geological Survey cooperative streamflowgaging network, and at seven partial-record stations installed in 2004 for this study. Because the model-calibration period preceded data collection at the partial-record stations, a continuous streamflow record was estimated at these stations by correlation with flows at nearby continuous-record stations to provide additional streamflow data for model calibration. Water-use information was compiled for 1996-2001 and included municipal and commercial/industrial withdrawals, private residential withdrawals, golf-course withdrawals, municipal wastewaterreturn flows, and on-site septic effluent return flows. Streamflow depletion was computed for all time-varying ground-water withdrawals prior to simulation. Water-use data were included in the model to represent the net effect of water use on simulated hydrographs. Consequently, the calibrated values of the hydrologic parameters better represent the hydrologic response of the basin to precipitation.

The model was calibrated for 1997-2001 to coincide with the land-use and water-use data compiled for the study. Four long-term stations (Nipmuc River near Harrisville, Rhode Island; Quinsigamond River at North Grafton, Massachusetts; Branch River at Forestdale, Rhode Island; and Blackstone River at Woonsocket, Rhode Island) that monitor flow at 3.3, 5.4, 19, and 88 percent of the total basin area, respectively, provided the primary model-calibration points. Hydrographs, scatter plots, and flow-duration curves of observed and simulated discharges, along with various model-fit statistics, indicated that the model performed well over a range of hydrologic conditions. For example, the total runoff volume for the calibration period simulated at the Nipmuc River near Harrisville, Rhode Island; Quinsigamond River at North Grafton, Massachusetts; Branch River at Forestdale, Rhode Island; and Blackstone River at Woonsocket, Rhode Island streamflowgaging stations differed from the observed runoff volume by $-8.6,3.9,-4.7$, and -5.3 percent, respectively. The errors between the observed and simulated mean daily streamflows for the calibration period were less than 10 percent at 12 of the 15 stations in the basin. The Nash-Sutcliffe coefficient for daily mean flows, a goodness-of-fit measure that represents the proportion of the variance in the observed flow explained by the model, ranged from 0.61 to 0.78 at the primary calibration stations. The simulated mean annual runoff from the basin was 23.1 inches for 1997-2001, of which about 44 percent was from forested areas overlying till, and about 11 percent was from forested areas overlying sand and gravel. The simulated mean annual evapotranspiration loss was 19.5 inches from the basin, of which about 63 percent was from forested areas. 


\section{Introduction}

The Blackstone River flows through a densely populated area of south-central Massachusetts and northern Rhode Island (fig. 1). The Blackstone River Basin is experiencing rapid population and commercial growth and changing land-use patterns throughout much of its area. The population in 36 of the 39 towns in the basin increased between 1990 and 2000 (U.S. Census Bureau, 2005). Five towns in the Massachusetts part of the basin had growth rates of more than 30 percent (U.S. Census Bureau, 2005). The majority of the growth was lowdensity residential development outside the established city centers. Residential, commercial, and industrial growth and transfers of water across basin boundaries are increasing the demand on water resources in the basin and raising concerns about the future availability of water to meet the needs of residents. As communities increase withdrawals to meet growing water-supply demands, streamflows decrease, potentially adversely affecting aquatic habitat, water quality, and the recreational value of streams in the basin.

Residents of the Blackstone River Basin use ground water and surface water for their drinking-water supplies. Watersupply wells generally tap thin (less than 100-ft thick) aquifers that are in direct hydraulic connection with the Blackstone River or its tributaries, ponds, and wetlands. As is the case with many river basins in New England, aquifers in the Blackstone River Basin are discontinuous, with the most productive parts of the aquifers following river channels (Johnston and Dickerman, 1974a and 1974b; Izbicki, 2000). In most instances, ground-water discharging to streams is the source of summer streamflow. Ground-water withdrawals decrease discharge to streams and can exacerbate low flows during dry periods in the summer. Surface-water withdrawals from streams have a direct and immediate effect on streamflow. Return flows from wastewater-treatment plants also affect streamflow in parts of the basin. Treated wastewater is a significant source of streamflow in the Blackstone River during the summer; these return flows reduce the effect of streamflow depletion on the main stem caused by withdrawals elsewhere in the basin. Land-use change that accompanies population growth also has the potential to affect the hydrology of the watershed, particularly by reducing recharge to the aquifer in developed, impermeable areas.

Local communities and state agencies have increasing concerns that water supplies in the basin may be unable to provide enough water to meet future demands. A corresponding environmental concern is that ground-water and surfacewater withdrawals associated with growth are exacerbating low-flow and water-quality problems in some parts of the Blackstone River Basin. Current (2006) demands on water resources and projected growth in the basin have created a need for increased understanding of the hydrology of the basin. In many areas, stresses to the hydrologically linked ground-water and surface-water systems extend across aquifer, town, and state boundaries, simultaneously affecting water- resource management and development plans for multiple communities. To address these concerns, the U.S. Geological Survey (USGS), in cooperation with the Rhode Island Water Resources Board (RIWRB), developed a surface-water model for the Blackstone River Basin. A Hydrological Simulation Program-FORTRAN (HSPF) precipitation-runoff model was developed and calibrated to study the effects of water use and land use on streamflow and the effects of water-management practices on regional water availability. Although the study emphasizes the Rhode Island part of the Blackstone River Basin, the entire basin was modeled.

\section{Purpose and Scope}

This report describes the development and calibration of the HSPF model for the Blackstone River Basin. It includes information on the climate, topography, surficial geology, and hydrology of the basin, as well as the land use and water use for 1997-2001 (the model-calibration period). The report also describes the external data used in the model, the methods used to process the data for inclusion in HSPF and estimate missing periods of record, and the methods used to estimate residential water use and wastewater disposal in the basin.

\section{Previous Investigations}

Water resources in the Blackstone River Basin have been studied extensively over the years by State and Federal agencies and other organizations, but many of these reports are not widely available. The most recent comprehensive study of water quality in the Blackstone River and its major tributaries, the Blackstone River Initiative, was conducted by the U.S. Environmental Protection Agency (USEPA), the Massachusetts Department of Environmental Protection (MADEP), and Rhode Island Department of Environmental Management (RIDEM) during the early 1990s (Wright and others, 2001). This study included water-quality sampling during wet and dry weather and sampling of sediments and wastewater effluent. Recent water-quality information for many streams and lakes in the basin was summarized by Weinstein and others (2001).

Several comprehensive water-use and management studies have been conducted in the last 20 years by the USGS and state agencies. Studies have documented water use in the major basins in Rhode Island (Craft and others, 1990); the town of Cumberland, Rhode Island (Horn and others, 1994); and the lower Blackstone River Basin including all of the basin area in Rhode Island (Barlow, 2003). Other wateruse information has been compiled in reports by the Rhode Island Department of Administration-Division of Planning (Rhode Island Department of Administration-Division of Planning, 1988 and 1991) and the Massachusetts Department of Environmental Management (Massachusetts Department of Environmental Management, 1985 and 1991). 


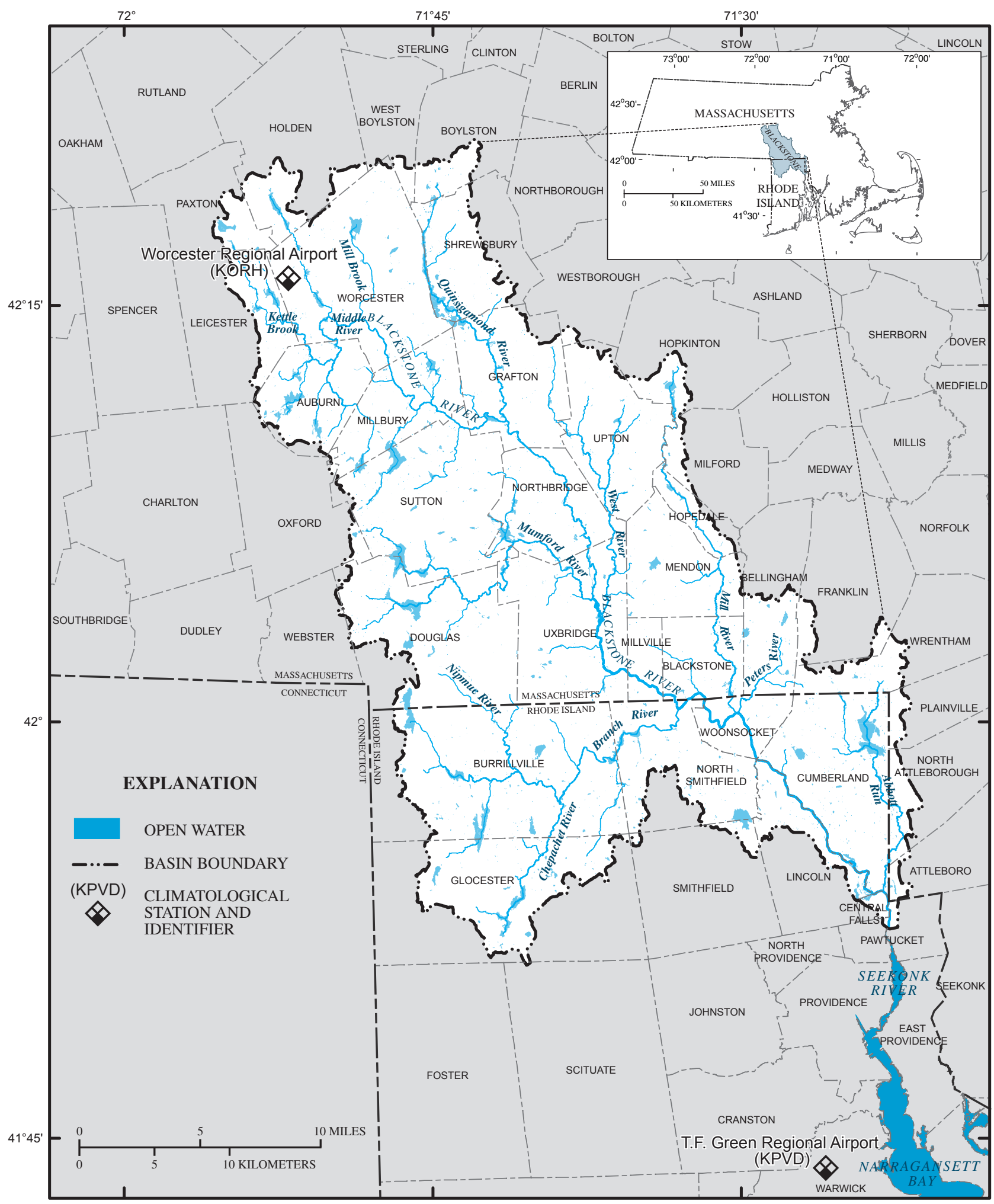

Base from U.S. Geological Survey, 1:24,000, 1995

Massachusetts state plane projection, NAD83

Figure 1. The Blackstone River Basin, towns, and climatological stations used to simulate streamflow, Massachusetts and Rhode Island. 
Studies of the ground-water and surface-water hydrology of the basin also have been conducted by the USGS and state agencies. These studies provide information on precipitation, recharge, streamflow, drainage-basin boundaries, aquifer properties, aquifer yields, and water quality. Study areas varied in size and most did not encompass the entire basin. Water resources in Massachusetts were investigated by Krejmas and Wandle (1982), Walker and Krejmas (1986), and Izbicki (2000), and in Rhode Island by Lang (1961), Johnson (1962), Johnston and Dickerman (1974a, 1974b, and 1974c), and Friesz (2004). Frimpter (1974) investigated ground-water management in the entire Blackstone River Basin. Flow characteristics of streams in the Massachusetts part of the basin were investigated by Wandle and Phipps (1984). The study described in this report is the first application of a precipitation-runoff model to investigate streamflow and water-management alternatives in the Blackstone River Basin.

\section{Description of the Basin}

The Blackstone River flows for 46 miles (mi) from its headwaters in Worcester, Massachusetts, the third largest city in New England, to the head of Narragansett Bay at Providence, Rhode Island, the second largest city (fig. 1). The Blackstone River Basin encompasses an area of 474.5 square miles $\left(\mathrm{mi}^{2}\right)$. Approximately 71 percent of the basin is in south-central Massachusetts and 29 percent is in northern Rhode Island (fig. 1). The Blackstone River begins below the confluence of the Middle River and Mill Brook in Worcester, Massachusetts and ends in Pawtucket, Rhode Island, at which point it becomes the tidal Seekonk River at the head of Narragansett Bay. The Blackstone River is the second largest source of freshwater to Narragansett Bay. The major tributaries, the Quinsigamond River, West River, Mumford River, Branch River, Mill River, Peters River, and Abbott Run, contribute roughly one-half of the total flow in the Blackstone River during low-flow conditions.

\section{Climate}

The climate in the basin is humid. Precipitation for 19602004 averaged 46.4 inches per year (in/yr) in the northern part of the basin (Worcester Regional Airport, Worcester, Mass., station 1999923) and $44.7 \mathrm{in} / \mathrm{yr}$ in the southern part of the basin (T.F. Green Airport, Warwick, R.I., station 376698). Worcester Regional Airport (also referred to as KORH) is located just west of the city of Worcester and T.F. Green Airport (also referred to as KPVD) is approximately $10 \mathrm{mi}$ south of the basin outlet (fig. 1). Average monthly precipitation is fairly uniform throughout the year. At T.F. Green Airport, average long-term monthly precipitation ranged from 2.94 inches (in.) in July to 4.24 inches in December. At the Worcester Regional airport, average long-term monthly precipitation ranged from 3.13 inches in February to 4.28 inches in September.
The average annual air temperature for 1960-2004 ranged from $47.0^{\circ} \mathrm{F}$ in the northern part of the basin to $50.8^{\circ} \mathrm{F}$ in the southern part of the basin. Average monthly temperatures for this period ranged from $23.4^{\circ} \mathrm{F}$ to $28.5^{\circ} \mathrm{F}$ in January and $69.5^{\circ} \mathrm{F}$ to $72.7^{\circ} \mathrm{F}$ in July in the northern and southern parts of the basin, respectively.

\section{Topography}

The regional slope of the basin is to the southeast, with altitudes ranging from about $1,390 \mathrm{ft}$ above sea level in the hilly region north and west of Worcester to $4 \mathrm{ft}$ above sea level where the Blackstone River enters Narragansett Bay at Pawtucket. The mean altitude in the basin is about $460 \mathrm{ft}$ above sea level. The western part of the basin is in the Central Highlands region and eastern part is in the Eastern Lowlands region (Denny, 1982). The topography of the northern and western parts of the basin is rolling with numerous steep, rocky hills. The southern part of the basin has less relief with relatively large areas of flatter ground. Slopes calculated from the USGS National Elevation Dataset (U.S. Geological Survey, 2005) ranged from 0 to approximately 50 percent, with an average slope of about 6 percent. The average slope of the Blackstone River Basin is among the steepest of comparably sized coastal basins in New England. The steep topography contributed to the early, widespread development of water power in the basin, which is commonly considered to be the birthplace of the industrial revolution in the United States (National Park Service, 2005).

\section{Land Use and Land Cover}

The Blackstone River Basin is predominantly forested (50.7 percent). The next largest land-use and land-cover (LULC) category is residential (21.3 percent), of which 14.7 percent is medium- to low-density residential and 6.6 percent is high-density residential, followed by open, non-residential (10.7 percent), forested and non-forested wetlands ( 7.7 percent), and commercial-industrial-transportation (5.8 percent). The remaining 3.8 percent of the basin is classified as open water. The methods used to develop these general categories from the more-detailed Massachusetts and Rhode Island LULC data layers are described in the "Representation of the Basin" section of the report.

Land use in the basin varies geographically (fig. 2). The northern and southeastern parts of the basin have substantial urban development, and the eastern side of the basin, near the Route 495 corridor, is generally more developed and populated than the western side. The western part of the basin below Worcester is relatively undeveloped with about 70 percent of the land classified as forest. Medium- to lowdensity development is distributed fairly uniformly across the basin. 


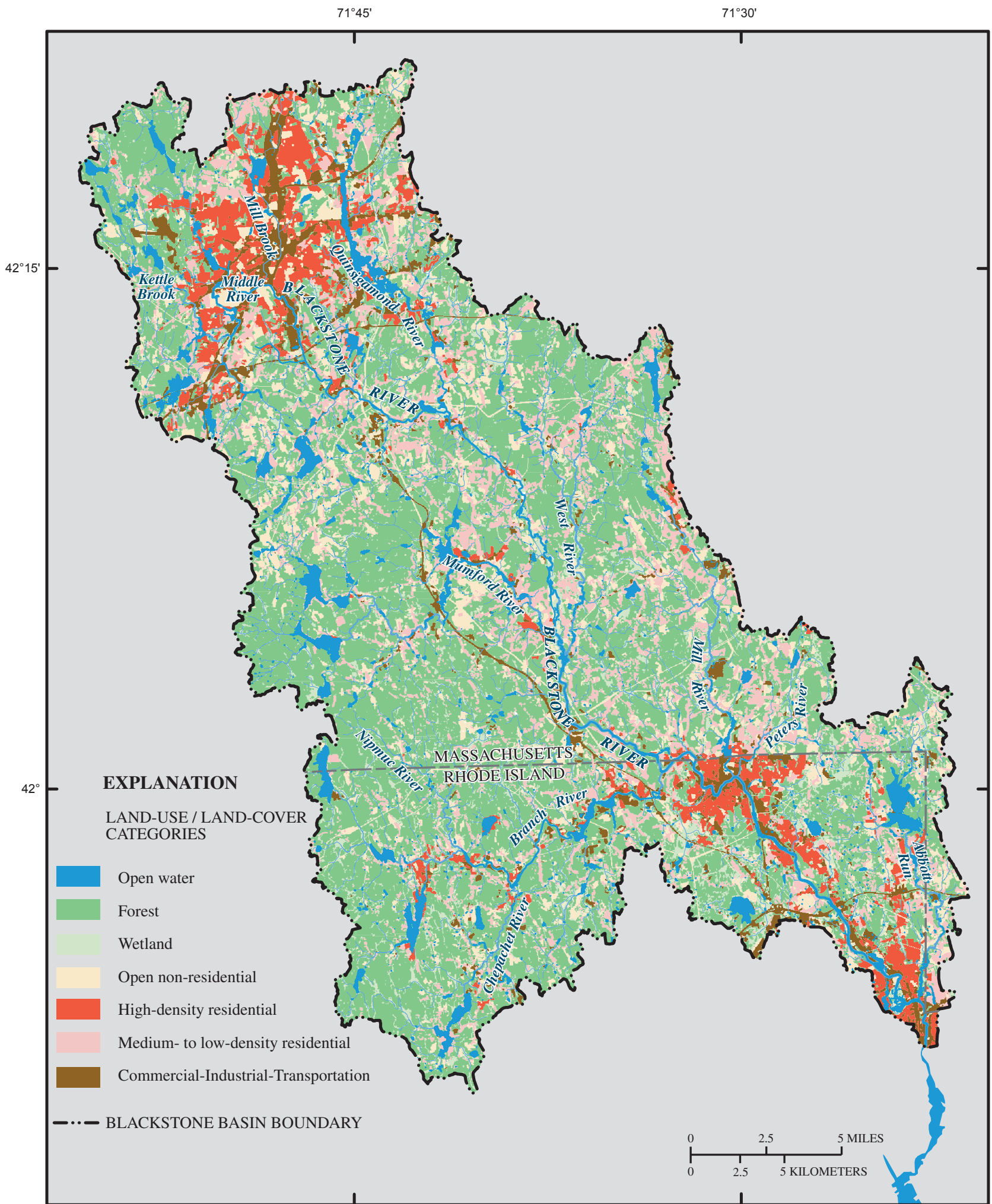

Base from U.S. Geological Survey, 1:24,000, 1995 Massachusetts state plane projection, NAD83

Figure 2. Land use in the Blackstone River Basin. 


\section{Surficial Geology}

Till and stratified glacial deposits that consist mainly of sand and gravel cover most of the basin (fig. 3). Till, which covers about 71 percent of the basin, is present mainly in upland areas (fig. 3). In southern New England, tills consist of unsorted material ranging in size from clay to boulders. Because the composition and degree of compaction vary widely, the permeability also varies widely. The horizontal hydraulic conductivity of tills derived from crystalline rocks has been found to range over approximately 4 orders of magnitude, from 0.004 feet per day (ft/d) for compact tills to $96 \mathrm{ft} / \mathrm{d}$ for loose, sandy tills (Melvin and others, 1992a). However, tills are compact and silty in most areas, so the lower end of this range is more representative of the hydraulic properties of tills in the basin (Randall and others, 1988). Tills are typically less than $15 \mathrm{ft}$ thick. Bedrock outcrops are prevalent in some upland areas but are not areally extensive in the basin.

Stream valleys are typically underlain by stratified glacial deposits. These stratified glacial deposits, which cover the remaining 29 percent of the basin, form the major aquifers in the basin. The sand and gravel aquifers in the lower part of the basin range from 10 to more than $120 \mathrm{ft}$ thick and have horizontal hydraulic conductivities from 10 to $480 \mathrm{ft} / \mathrm{d}$ and transmissivities up to 40,000 feet squared per day $\left(\mathrm{ft}^{2} / \mathrm{d}\right)$ (Johnston and Dickerman, 1974a,b). Many of these aquifers have been developed for water supply. Recently deposited fine-grained alluvial sediments also are present locally in the stream valleys.

\section{Streamflow-Gaging Stations and Hydrology}

The USGS currently (2006) operates eight continuousrecord streamflow-gaging stations in the basin as part of the ongoing cooperative stream-gaging network (fig. 4; table 1). Seven additional streamflow-gaging stations (also referred to as project stations) were installed between October 2003 and January 2004 for this study (fig. 4). Flows in the urbanized and densely populated headwaters of the basin are measured at stations on Kettle Brook at Auburn, Mass. (station no. 01109439), the Quinsigamond River at North Grafton, Mass. (station no. 01110000), and the Blackstone River at Millbury, Mass. (station no. 01109730). Flows in these drainage areas are influenced by the relatively large amount of impervious area (10 percent), the presence of an extensive storm- and sanitary-sewer system that includes an area of combined sewers in downtown Worcester, and reservoir management associated with the Worcester water-supply system. Blackstone River flows at the Millbury station also are strongly influenced by return flows from the Upper Blackstone Water
Pollution Abatement District (UBWPAD) treatment plant, $2.5 \mathrm{mi}$ upstream. Mean annual discharge at the Millbury station for the period of record (2002-2004 water years ${ }^{1}$ ) was 175 cubic feet per second $\left(\mathrm{ft}^{3} / \mathrm{s}\right)$. The highest peak discharge at this station was 3,450 ft $3 / \mathrm{s}$ in April 2004 and the lowest daily mean discharge was $28 \mathrm{ft}^{3} / \mathrm{s}$ in August 2002 and October 2003 (Socolow and others, 2005).

Flows in the major tributaries in the central part of the basin are measured at streamflow-gaging stations on the Mumford River at Uxbridge, Mass. (station no. 01111050); the Branch River at Forestdale, R.I. (station no. 01111500); the West River at Uxbridge, Mass. (station no. 01111200); the Peters River at Woonsocket, R.I. (station no. 01112382); and the Mill River at Woonsocket, R.I. (station no. 01112268) (fig. 4). Flows in all four drainage areas are affected to varying degrees by water-supply withdrawals, wastewater-return flows and reservoir management. In particular, peak flows in the West River are affected by regulation at the West Hill Dam for flood control, and low flows in the Mill River may be affected by periodic withdrawals from Harris Pond to supplement the City of Woonsocket water supply during peak demand. The drainage area to the station on the Blackstone River at Woonsocket, R.I. (station no. 01112500), below these major tributaries, is $416 \mathrm{mi}^{2}$ or approximately 88 percent of the basin area. This station has been in operation since 1929 , providing a long-term record of streamflow in the basin. The mean annual discharge at the Woonsocket station for the period of record was $775 \mathrm{ft}^{3} / \mathrm{s}$, with a maximum peak discharge of 32,900 ft $3 / \mathrm{s}$ in August 1955, and a minimum daily mean discharge of $21 \mathrm{ft}^{3} / \mathrm{s}$ in August 1934 (Socolow and others, 2005).

Flows in the drainage area between the Woonsocket station and the mouth of the basin are measured at the stations on Abbott Run at Valley Falls, R.I. (station no. 01113760) and the Blackstone River at Pawtucket, R.I. (station no. 01113895). Similar to the Worcester area, this part of the basin is relatively urban, with a higher population density, more impervious area, and a greater proportion of the drainage area served by public water and sewers than other parts of the basin. Water supplies for the cities of Woonsocket (withdrawn from Crookfall Brook and Mill River) and Pawtucket (withdrawn from Abbott Run) are obtained from this part of the basin. Streamflow in the Abbott Run subbasin is affected by surface-water and ground-water withdrawals and reservoir management for the city of Pawtucket water supply. The drainage area to the station on the Blackstone River at Pawtucket is $474 \mathrm{mi}^{2}$, representing nearly 100 percent of the basin area. The mean annual discharge at the Pawtucket streamflow-gaging station for the period of record (2004 water year) was $852 \mathrm{ft}^{3} / \mathrm{s}$. Flow at this station is highly correlated to flow at the Woonsocket station.

\footnotetext{
${ }^{1}$ The water year begins on October 1 and ends on September 30 of the following year. For example, water year 2005 began October 1, 2004 and ended September 30, 2005.
} 


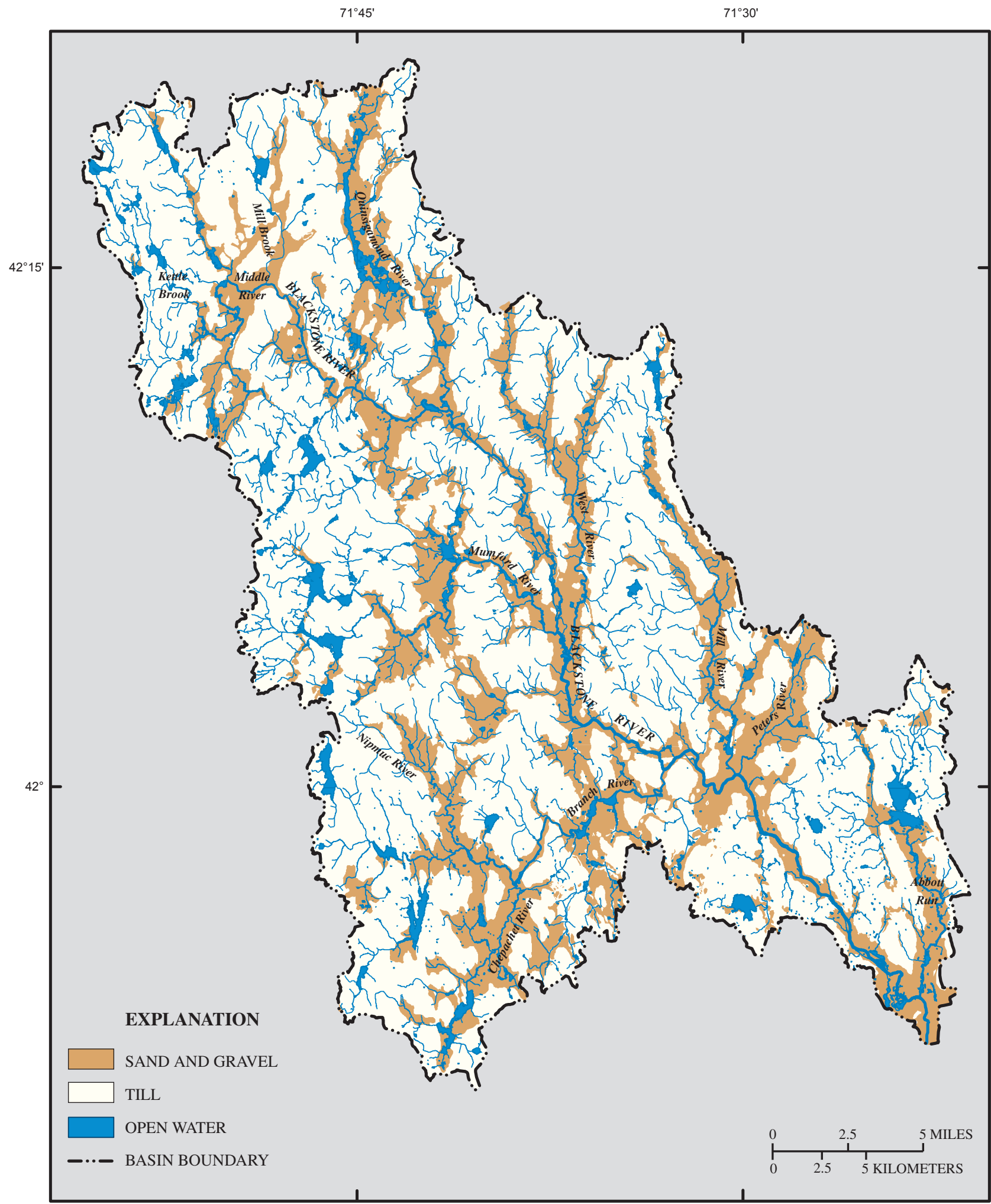

Base from U.S. Geological Survey, 1:24,000, 1995 Massachusetts state plane projection, NAD83

Figure 3. Surficial geology in the Blackstone River Basin. 


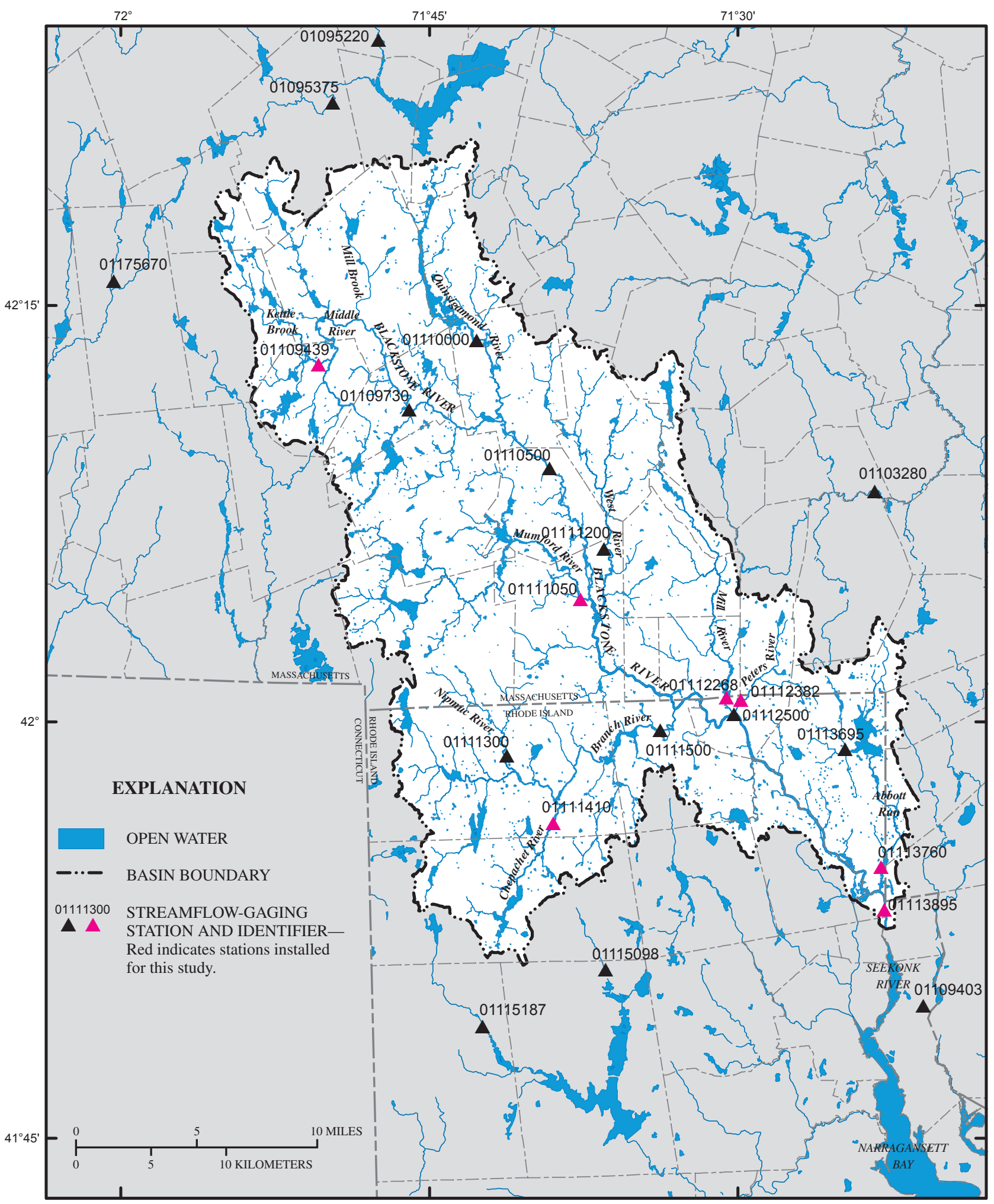

Base from U.S. Geological Survey, 1:24,000, 1995 Massachusetts state plane projection, NAD83

Figure 4. Streamflow-gaging stations in the Blackstone River Basin and surrounding areas. 
Table 1. Streamflow-gaging stations in the Blackstone River Basin, Massachusetts and Rhode Island.

[USGS, U.S. Geological Survey; period of record represents the streamflow data available at the time of model development; $\mathrm{ft}^{3} / \mathrm{s}$, cubic feet per second; $\mathrm{mi}^{2}$, square miles; Mass., Massachusetts; R.I., Rhode Island]

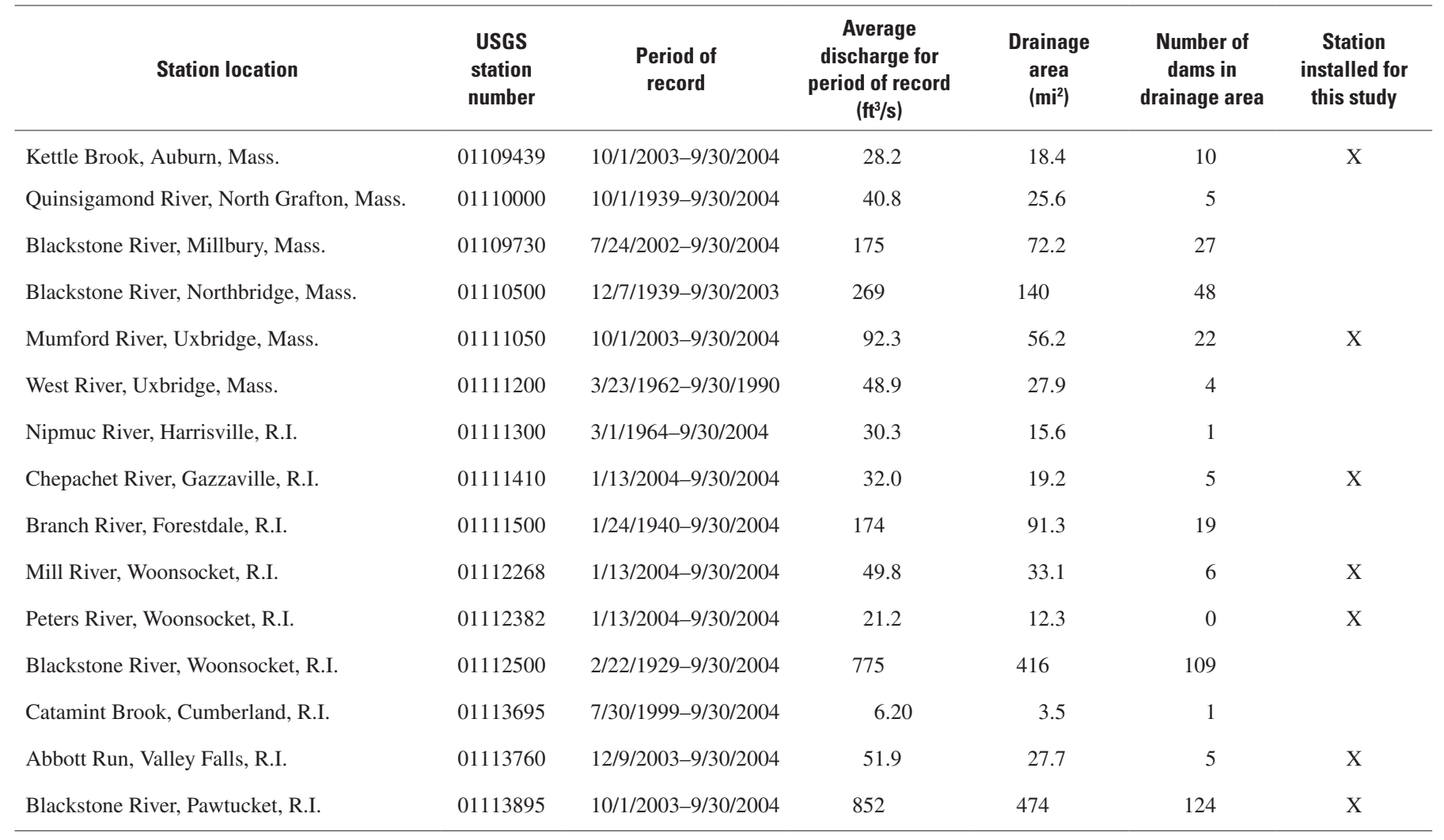

The average slope of the Blackstone River between Worcester and the mouth of the basin is about 7 feet per mile (ft/mi). Approximately 125 dams with heights greater than $6 \mathrm{ft}$ (Federal Emergency Management Agency, 1994) and wetlands in the stream valleys create flat-water conditions throughout the basin. A majority of the dams are relatively low-profile "run-ofriver" structures that do not produce large ponded areas. Larger dams with flow-control structures are present on the recreational, flood-control, and water-supply reservoirs. There also are five facilities that generate hydroelectric power (Riverdale Mills, Thundermist, Synergics, Elizabeth Webbing, and Central Falls) and one thermoelectric power-generation facility (Ocean State Power) on the Blackstone River. The hydroelectric facilities attempt to keep inflow and outflow rates equal to maintain aquatic habitat and water quality, and are thus considered run-of-river facilities (Barlow, 2003). As such, these facilities are not considered explicitly in the HSPF model. Withdrawals from the Ocean State Power facility are 100 percent consumed by evaporation, and hourly withdrawals from this facility are included in the model.

\section{Wetlands}

Combined forested and non-forested wetlands compose about 7.7 percent of the basin area (23,395 acres). Approximately 71 percent of the wetlands are forested (fig. 5).

Wetlands are fairly evenly distributed throughout the basin, mainly as discontinuous areas bordering stream channels. More extensive wetlands are present along the Blackstone River above the confluence with the West River in Uxbridge, and in the southeastern part of the basin. Fewer wetlands are in the headwaters of the basin in Worcester and adjacent developed areas. Wetlands in proximity to stream channels are an important aspect of the hydrology of the basin because they reduce peak flows and increase evapotranspiration losses (Zarriello and Bent, 2004). 


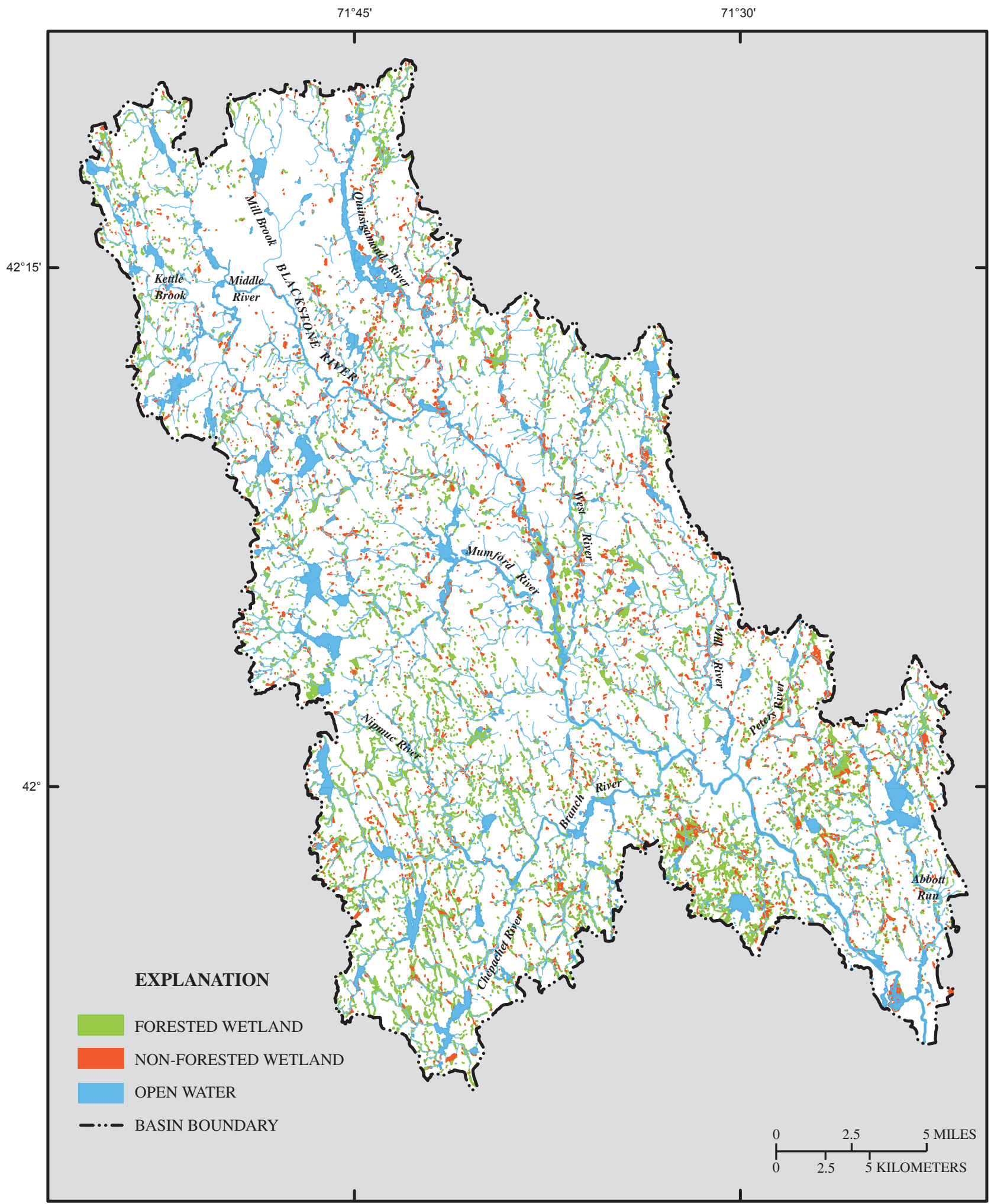

Base from U.S. Geological Survey, 1:24,000, 1995

Digital wetland data from MassGIS, 2004; RIGIS, 1993 Massachusetts state plane projection, NAD83

Figure 5. Wetlands in the Blackstone River Basin. 


\section{Water Use}

In 2000, approximately 467,000 residents lived in the Blackstone River Basin (U.S. Census Bureau, 2004a,b). A summary of municipal water use for the towns in the basin is provided in table 2 . There are 27 major public-water suppliers in the basin, of which 18 are in Massachusetts and 9 are in Rhode Island. Water suppliers may rely upon their own sources, purchase water from other suppliers, or use a combination of sources. For towns near the basin boundary, water from outside the basin may be conveyed across the basin boundary to a given distribution area. Similarly, wastewater in public sewer systems may be conveyed outside the basin for disposal. The distribution of public water and public sewer systems is shown in figure 6 .

Both surface water and ground water are used for water supply. Woonsocket, R.I., and Worcester, Mass., use surface water as the sole source, whereas Cumberland, R.I., and Pawtucket, R.I., use a combination of surface water and ground water. Worcester also imports water from the Nashua River Basin to supplement its water supply. Other communities rely primarily on ground water obtained from municipal wells completed in sand and gravel aquifers. Residents in areas not served by public water systems obtain water from private wells completed in either the bedrock or sand and gravel aquifers.

Water is used to meet domestic, commercial, industrial, and agricultural needs. For 1995-1999, the largest aggregate withdrawal in the lower Blackstone River Basin $\left(198 \mathrm{mi}^{2}\right)$ was for domestic supply (50 percent), followed by industrial (20 percent), commercial (20 percent), and irrigation (1 percent), which includes agricultural and golf-course irrigation (Barlow, 2003). The remaining 9 percent of water use was not accounted for in supplier's billing records (non-account water use). Data show that domestic water use is highest during the summer months due to lawn and garden watering and other seasonal uses. Similar water-use statistics for the entire basin are not available, but patterns are likely similar. Water-withdrawal information compiled for the entire basin for this study indicates that total municipal and commercial/industrial water withdrawals averaged about 66 million gallons per day (Mgal/d) for 1997-2001.

Wastewater disposal takes place at National Pollution Discharge Elimination System (NPDES) permitted outfalls and private septic systems. The Blackstone River Basin receives wastewater-return flows from 10 municipal wastewater-treatment facilities. In the lower Blackstone River Basin, 68 percent of the total wastewater disposal for 19951999 was municipal wastewater disposed at treatment-facility outfalls (Barlow, 2003). The remaining 32 percent was selfdisposed, of which 25 percent was disposed at commercial and industrial NPDES outfalls and 75 percent was disposed at private septic systems. Similar wastewater-disposal statistics for the entire basin are not available, but disposal patterns are likely similar. Water-return information compiled for the entire basin for this study indicates that total return flows from wastewater-treatment facilities and commercial and industrial NPDES outfalls averaged about $54 \mathrm{Mgal} / \mathrm{d}$ for 1997-2001.

\section{Precipitation-Runoff Model for the Blackstone River Basin}

Streamflow in the Blackstone River Basin was simulated with HSPF, version 12 (Bicknell and others, 2000). HSPF was chosen because it produces detailed simulations of streamflow, which is a primary subject of the study, and because HSPF has been successfully used to study watermanagement alternatives in other basins in New England (Zarriello and Bent, 2004; Zarriello and Ries, 2000). The software code for HSPF is publicly available, free, and has been rigorously tested by developers and users. The HSPF model of the Blackstone River Basin was developed by (1) developing a conceptual model to represent the hydrology of the basin, (2) compiling and processing the necessary input data and constructing the model, (3) calibrating the model to improve the simulation accuracy, and (4) evaluating the performance of the calibrated model.

\section{Functional Description of HSPF}

HSPF is a mathematical model designed to simulate the hydrology and water quality of a river basin; however, only the hydrologic-simulation capability of HSPF was used in this study. Runoff from a basin is quantified by the continuous simulation of hydrologic response to climatic and human stresses on the basis of the principle of conservation of water mass - that is, inflow equals outflow plus or minus changes in storage. In HSPF, a basin is represented by a group of hydrologically similar areas that are referred to as hydrologic response units (HRUs) that drain into a network of reaches (RCHRESs) consisting of streams, lakes, or reservoirs. The drainage area around each RCHRES is referred to as a subbasin. For each HRU and RCHRES, the model computes a water budget (inflows, outflows, and changes in storage) for each time step. A complete description of the processes involved in computing water budgets and required input model parameters is given in the "HSPF User's Manual" (Bicknell and others, 2000). In the following discussion, model features such as parameters, computed time series, control files, and model block names are denoted by capital letters.

HRUs reflect areas of similar land use, surficial geology, and other factors deemed important to produce a similar hydrologic response to precipitation and potential evapotranspiration. HRUs are divided into pervious-area land segments (PERLNDs) and impervious-area land segments (IMPLNDs). These land segments are represented by zones, which define storages, and processes, which move water between the zones. PERLNDs and IMPLNDs have zones that retain precipitation at the surface as interception storage or snowpack storage. All water that is not evaporated produces surface runoff from IMPLNDs. By contrast, PERLNDs allow excess precipitation to infiltrate into the subsurface, where storages and processes are represented by upper, lower, and ground-water zones. 


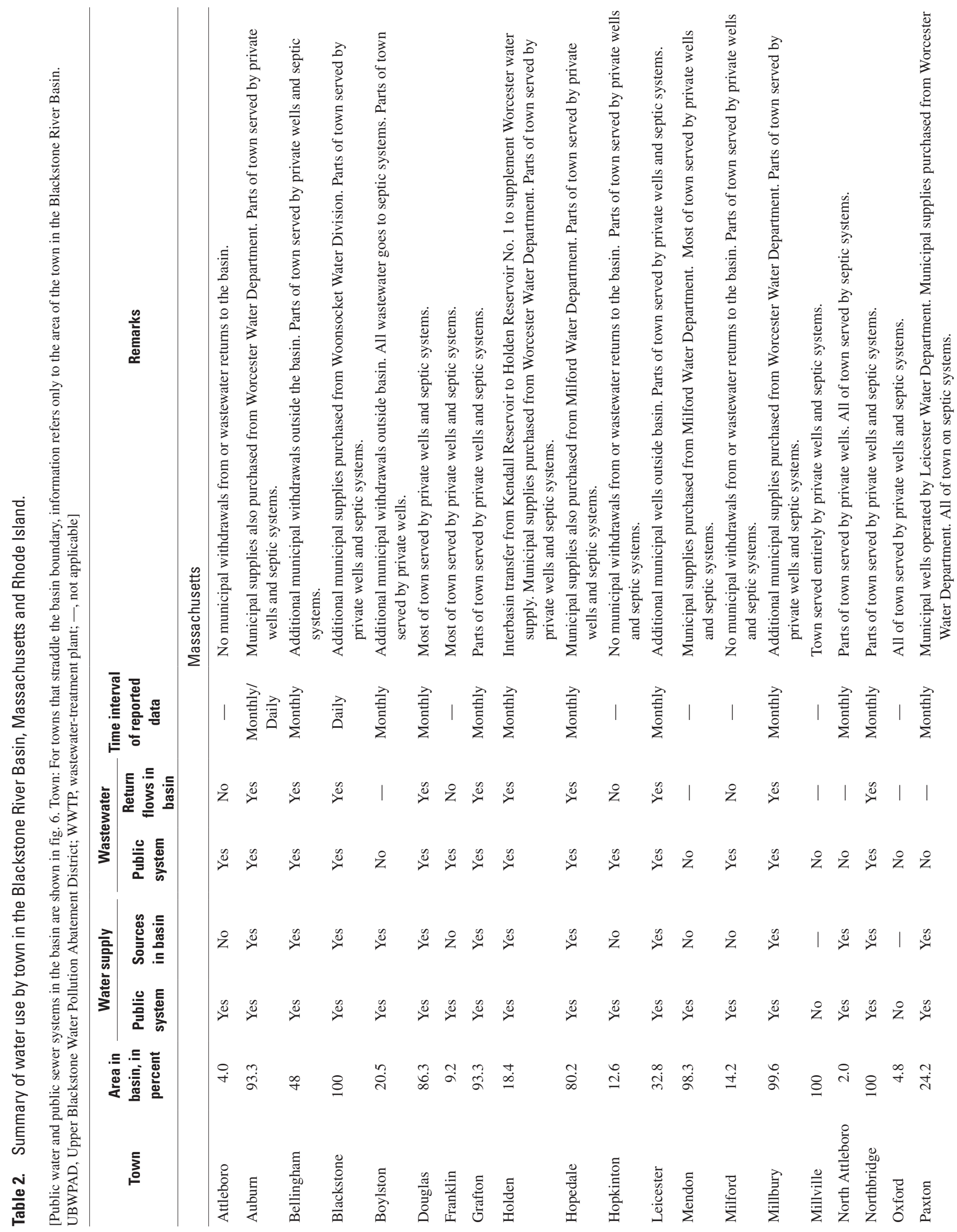




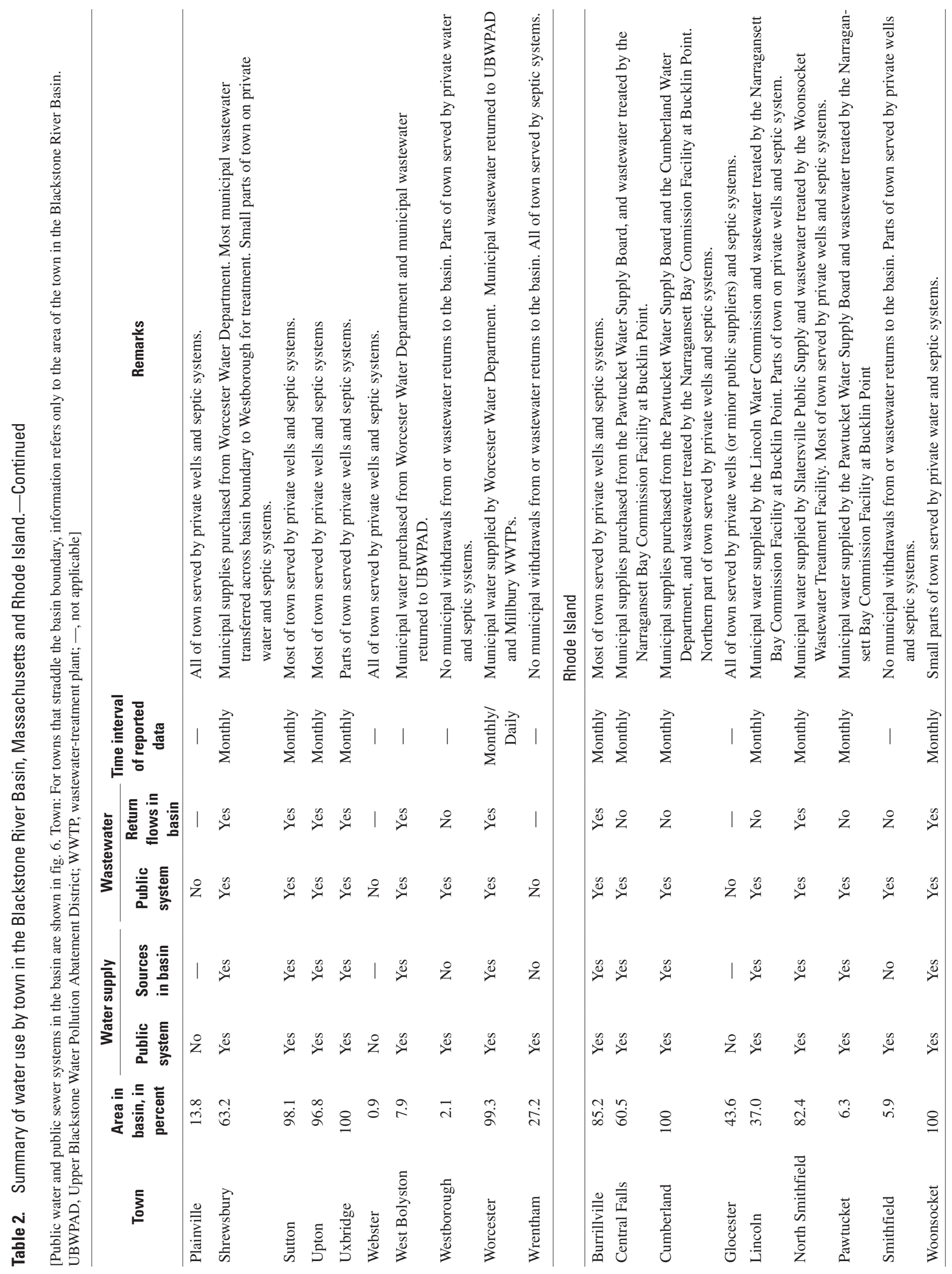




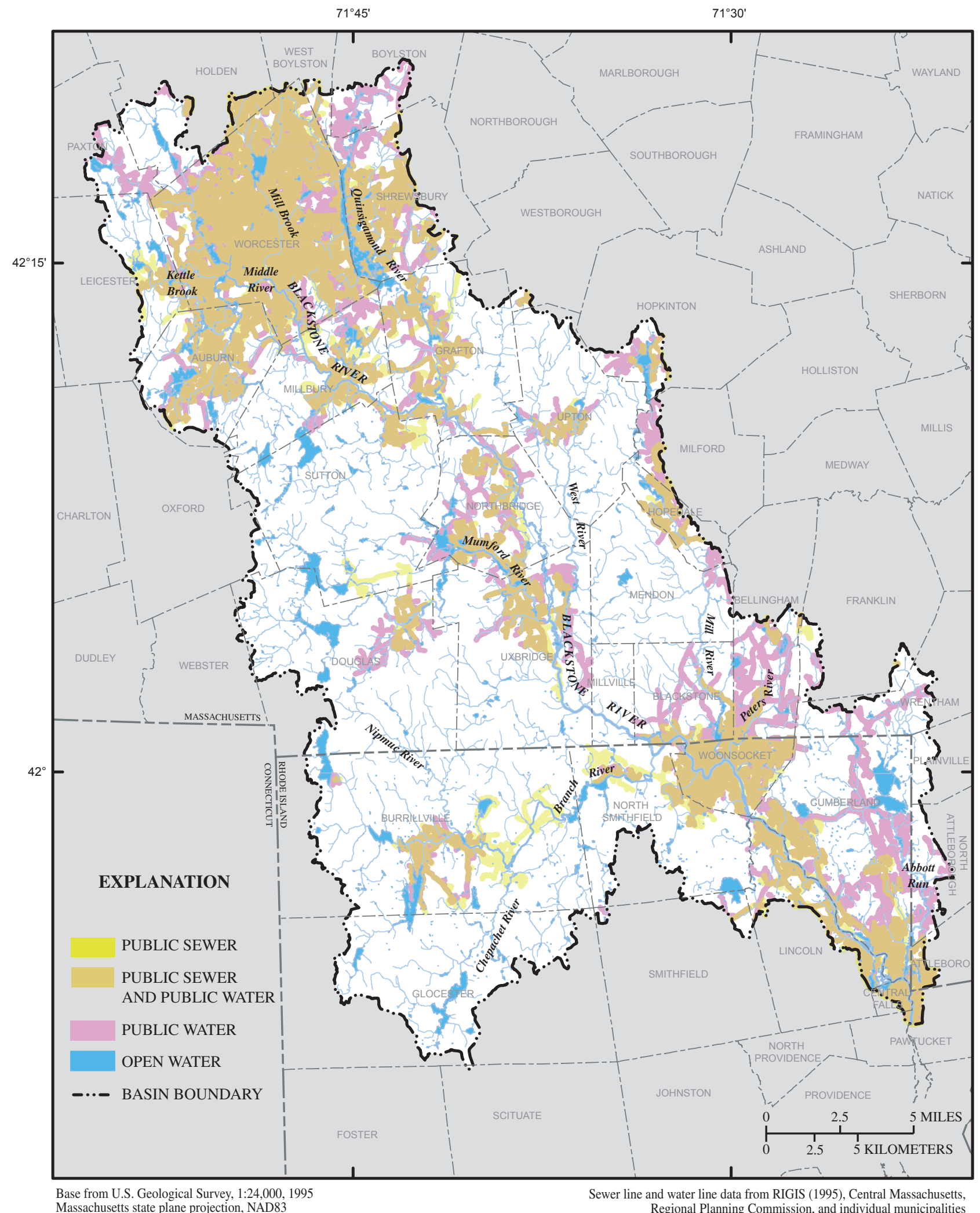

Figure 6. Distribution of public water and public sewer systems in the Blackstone River Basin. 
Processes that control the rate of infiltration and change in subsurface storage make simulation of PERLNDs considerably more complex than simulation of IMPLNDs. In the model simulation, surface runoff from PERLNDs and IMPLNDs, and subsurface discharge from PERLNDs are typically directed into reaches; however, water can be directed elsewhere if desired.

RCHRESs are model elements that represent a length of stream channel or reservoir. The downstream end of each RCHRES is referred to as a node. Nodes are typically placed to define channel segments with similar physical properties, such as reach segments with similar slope and width, junctions of tributary streams, lakes and reservoirs, and locations of data-collection sites. Nodes can be placed at other locations where estimates of streamflow are desired, such as upstream and downstream from municipal well fields, water diversions, or discharges of contaminants. The hydraulic characteristics used for kinematic wave routing of water in a RCHRES are defined by its storage-discharge properties specified in a function table (FTABLE) of the model input. The FTABLE characterizes the hydraulic properties of the reach by defining the relation between depth, storage, and discharge.

HSPF requires two primary input files for its operation, the User Control Input (UCI) file and the Watershed Data Management (WDM) file. The UCI file directs the modelprocess algorithms and sets user-specified input parameters. The three primary model elements, PERLNDs, IMPLNDs, and RCHRESs, are organized by blocks in the UCI file. Within each block are modules and submodules that define the movement of water and changes in storage between zones. Some modules are mandatory for simulations and others are optional. For example, the PERLND block requires the PWATER module to simulate the movement of water, but the SNOW module is optional for simulating snowpack buildup and melt. The SCHEMATIC or NETWORK blocks are used to represent the physical layout of the basin. The area of each IMPLND and PERLND that drains to a RCHRES (also referred to as a reach) is defined in this section of the model to formulate subbasins. The SCHEMATIC or NETWORK blocks also are used to define the linkage of one RCHRES to another. The MASSLINK section associated with a SCHEMATIC block or NETWORK block controls the linkage of flow components between model elements. Typically, this linkage involves routing (1) surface runoff from PERLNDs and IMPLNDs to reaches, (2) interflow and base flow from PERLNDs to reaches, and (3) streamflow from reach to reach. A number of other blocks are required for administrative functions, such as controlling the operational sequence of the program, directing the model to external sources of data, writing outputted time-series data, and defining the linkage between model elements. Blocks also are available for data manipulation, displaying and reporting model results, and other optional model features.
The inflows to and outflows from a stream reach, as defined for the Blackstone River Basin model, are illustrated in figure 7. Surface runoff can discharge to a reach from impervious surfaces (SURI) and pervious surfaces (SURO). Infiltrated water can discharge to the reach through the subsurface as interflow (IFWO), which is analogous to a fast-responding shallow subsurface flow, or from active ground water (AGWO), which is analogous to a slow-responding base-flow component, or, optionally, exit from an HRU as a deep ground-water flow that discharges outside of the basin (IGWI). Inflow to a reach also can come from upstream reaches (IVOL), direct precipitation, and other user-specified point sources such as treated wastewater.

Volumetric outflow from a reach can be directed through five outflow exits (or gates). As illustrated in figure 7, up to three outflow exits were designated for each reach in the Blackstone River Basin model. Water from the time series of total municipal and commercial/industrial withdrawals was directed through the first outflow exit (OVOL 1) in reaches with this type of withdrawal. Water from the time series of cumulative residential withdrawals from private wells in areas with public sewers in the reach was directed through the second outflow exit (OVOL 2) in reaches with this type of withdrawal. Time series directed through exits 1 and 2 are read from the EXTERNAL SOURCES block of the UCI file from arrays OUTDGT 1 and OUTDGT 2, respectively. Water was routed downstream through the third outflow exit (OVOL 3) in reaches with both types of withdrawals; in reaches with no withdrawals, a single outflow exit representing outflow to the downstream reach was specified.

\section{Input Data Used for the Model}

The WDM file is a binary file that efficiently stores large amounts of data. The WDM file stores input time-series data required for simulations and output time-series data generated by the model. The EXTERNAL SOURCES block of the UCI file reads data from the WDM file, and model generated timeseries are passed to the WDM file through the EXTERNAL TARGETS block of the UCI file. Output time series can be generated for any component in the simulation process defined in the "Time Series Catalog" section of the user's manual, but streamflow time series are the primary output. Time-series data in the WDM file can be accessed, displayed, transformed, and plotted by use of software programs such as ANNIE, (Flynn and others, 1995), GenScn (Kittle and others, 1998), or WDMUtil (U.S. Environmental Protection Agency, 2004).

Dataset numbers (DSNs) and attribute information must exist in the WDM file to pass time-series data between the WDM file and the model. The WDM file is organized by DSNs and relational attribute information. The organization of the WDM file developed for the Blackstone River Basin model is summarized in table 3. The first 100 DSNs are used to store measured climatological and streamflow time series. 


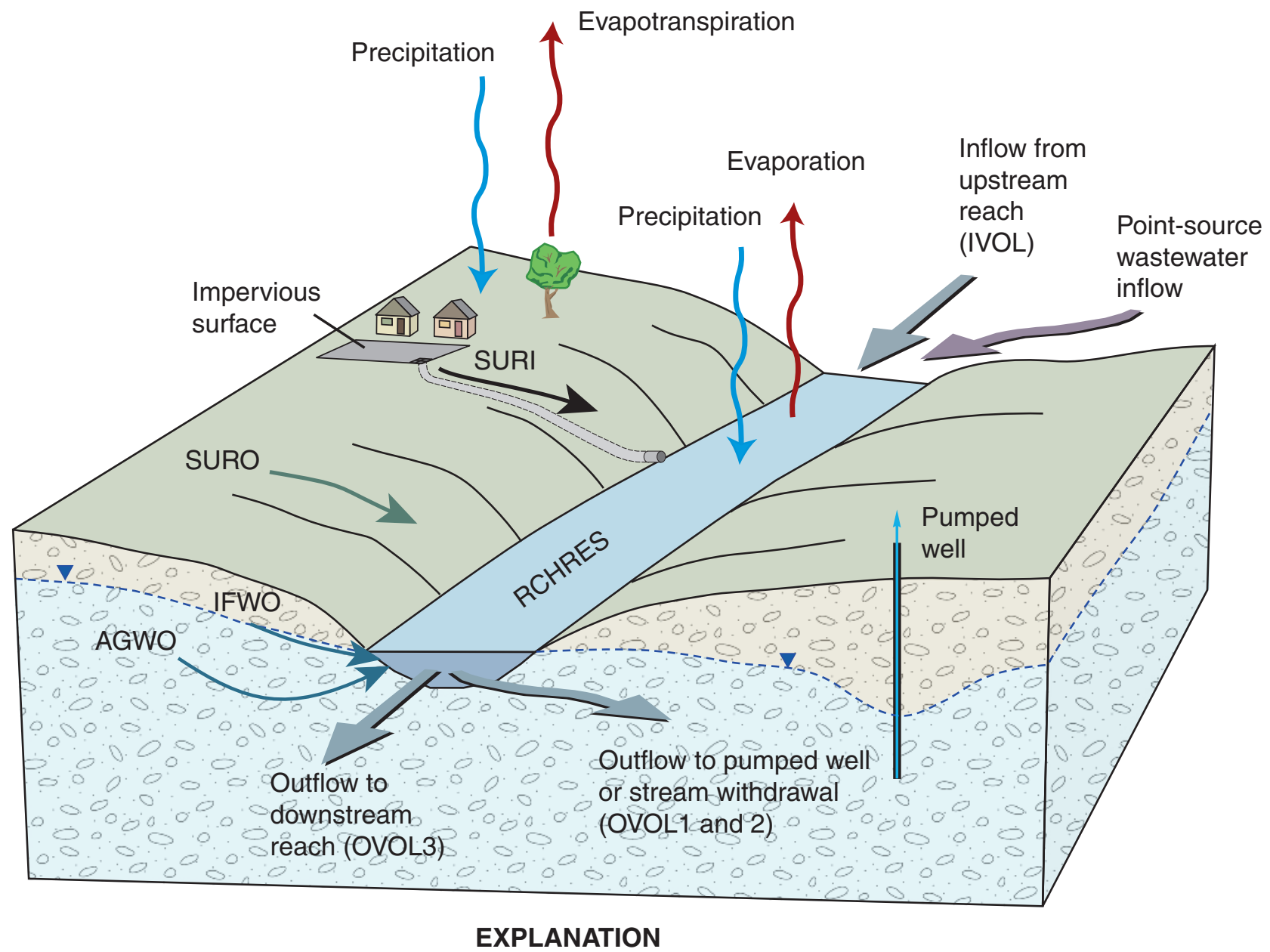

SURI-Surface runoff from impervious areas

SURO-Surface runoff from pervious areas

IFWO-Interflow (subsurface flow that responds rapidly to precipitation)

AGWO-Active ground-water flow (base flow)
RCHRES-Stream reach or reservoir segment

IVOL-Inflow volume

OVOLx-Outflow volume through individual exits $(x=1-5)$ SURI-Surface runoff from impervious areas

SURO-Surface runoff from pervious areas

Figure 7. Inflows and outflows to a Hydrological Simulation Program-FORTRAN (HSPF) stream reach. (Modified from Zarriello and Bent, 2004.)

Datasets with numbers larger than 100 are used to store input withdrawal and return flow time series and model-generated streamflow time series, and are generally organized by reach. Attributes describe the data type, time step, location, and other important features of the data. The data type used in GenScn is defined by the constituent attributes IDCONS, which are defined for the Blackstone River Basin in table 4. The methods used to develop the climatological, withdrawal, return flow, and streamflow data time series for the HSPF model are described in the following sections. 
Table 3. Organization and description of Dataset Numbers (DSNs) in the Watershed Data Management (WDM) file for the Hydrological Simulation Program-FORTRAN (HSPF) model of the Blackstone River Basin, Massachusetts and Rhode Island.

\begin{tabular}{|c|c|}
\hline DSN & Purpose \\
\hline $1-100$ & $\begin{array}{l}\text { Measured and computed climatic and streamflow data (DSN } 6 \text { is a constant used with a multiplier to compute residential } \\
\text { withdrawals) }\end{array}$ \\
\hline $101-150$ & Total withdrawals from a stream reach \\
\hline $200-250$ & Simulated hourly streamflow output by reach \\
\hline $301-350$ & Total withdrawals satisfied by streamflow for a reach \\
\hline $401-450$ & Total wastewater returns to a reach \\
\hline $501-549$ & Simulated daily streamflow output by reach \\
\hline $1000-1009$ & Miscellaneous withdrawals and return flows computed from other time series \\
\hline 2010-2509 & $\begin{array}{l}\text { Individual surface-water withdrawals, constant-rate ground-water withdrawals, and stream depletion from time-varying } \\
\text { ground-water withdrawals, where }\end{array}$ \\
\hline $\mathrm{x} 01 \mathrm{x}-\mathrm{x} 50 \mathrm{x}$ & second and third digits identify reach number, and \\
\hline $\mathrm{xxx} 0-\mathrm{xxx} 9$ & last digit identifies individual withdrawal points (QU1A has additional withdrawals designated 9110, 9111, and 9112) \\
\hline 3010-3509 & Individual wastewater return flows, where \\
\hline $\mathrm{x} 01 \mathrm{x}-\mathrm{x} 50 \mathrm{x}$ & second and third digits identify reach number, and \\
\hline $\mathrm{xxx} 0-\mathrm{xxx} 9$ & last digit identifies individual return points \\
\hline 4001-4016 & Simulated deep ground-water discharge \\
\hline 5000-5149 & $\begin{array}{l}\text { Output of simulated flow components by drainage area for the Expert System for the Calibration of the Hydrological } \\
\text { Simulation Program-FORTRAN (HSPEXP) program }\end{array}$ \\
\hline
\end{tabular}

\section{Climate}

Climatological data were obtained from the Northeast Regional Climate Center (NRCC). Data from T.F. Green Airport in Warwick, R.I. (KPVD, station no. 376698) and Worcester Regional Airport in Worcester, Mass. (KORH, station no. 99923), shown in figure 1, were used as input to the HSPF model. These two stations are the only first-order (stations that collect data in addition to precipitation and daily air temperatures) National Weather Service stations near the basin. The northwestern part of the basin was assigned the climatological data from the Worcester station and the southeastern part of the basin was assigned the climatological data from the Warwick station. The boundary between the two zones was set to coincide with the subbasin boundaries (fig. 8). The position of the climatological boundary was determined by calculating long-term precipitation and temperature statistics for seven nearby climatological stations, and comparing them to statistics from the Worcester and Warwick stations. Although there was considerable spatial scatter, a NW-SE trend was evident in the data, and the climate boundary was set at the approximate geographic midpoint between the two stations.

Climatological data stored in the WDM file include precipitation, potential evapotranspiration, air temperature, dewpoint temperature, solar radiation, and wind speed. Precipitation and potential evapotranspiration are required by HSPF to simulate the movement of water, and the remaining parameters are required to simulate the accumulation and melting of snow and ice. All these climatological data, with the exception of solar radiation, were obtained in hourly time steps for January 1, 1960 to December 31, 2004. NRCC provides daily solar radiation (Langleys) computed from other climatological variables. WDMUtil was used to disaggregate the daily solar-radiation values to the hourly values needed for the snow calculations. The Jensen-Haise method (Jensen and Haise, 1963; Rosenberry and others, 2004) was used to calculate daily potential evapotranspiration. To remove seasonal bias in potential evapotranspiration losses, the monthly variable coefficients used in the Jensen-Haise computation were adjusted from default values during model calibration. WDMUtil was used to disaggregate the daily potential evapotranspiration values to the hourly values needed for the simulations.

Data gaps in the precipitation, air temperature, dew-point temperature, and wind speed records were estimated by calculating the mean of the measured values bracketing the missing interval. About 25 percent and 14 percent of the data from 1960-2004 were missing at Worcester and Warwick, respectively. Most of the missing data (about 75 percent at Warwick and 98 percent at Worcester) were prior to 1980. The longest continuous interval of missing data for each station was 48 hours. 
Table 4. Constituent attributes (IDCONs) for the Watershed Data Management (WDM) file of the Hydrological Simulation Program-FORTRAN (HSPF) model of the Blackstone River Basin, Massachusetts and Rhode Island.

$\left[\mathrm{ft}^{3} / \mathrm{s}\right.$, cubic feet per second; mi/hr, miles per hour; ${ }^{\circ} \mathrm{F}$, degrees Fahrenheit; PERLND, pervious land segment; IMPLND, impervious land segment; HSPEXP, expert system for the calibration of the Hydrological Simulation Program-FORTRAN model]

\begin{tabular}{|c|c|}
\hline IDCONS & Explanation (units) \\
\hline FLOW & Measured streamflow $\left(\mathrm{ft}^{3} / \mathrm{s}\right)$ \\
\hline SIMQ & Simulated streamflow, hourly and daily $\left(\mathrm{ft}^{3} / \mathrm{s}\right)$ \\
\hline \multicolumn{2}{|r|}{ Climatological data } \\
\hline TEMP & Measured air temperature, hourly $\left({ }^{\circ} \mathrm{F}\right)$ \\
\hline MINTEMP & Minimum air temperature, daily $\left({ }^{\circ} \mathrm{F}\right)$ \\
\hline MAXTEMP & Maximum air temperature, daily $\left({ }^{\circ} \mathrm{F}\right)$ \\
\hline DEWP & Measured dew-point temperature, hourly $\left({ }^{\circ} \mathrm{F}\right)$ \\
\hline WIND & Measured wind speed, hourly (mi/hr) \\
\hline PREC & Measured precipitation, hourly (inches) \\
\hline DEVT & Computed potential evapotranspiration, daily (inches) \\
\hline PET & Computed potential evapotranspiration, hourly (inches) \\
\hline SOLR_DA & Computed solar radiation, daily (Langleys) \\
\hline SOLR & Computed solar radiation, hourly (Langleys) \\
\hline \multicolumn{2}{|r|}{ Water-use data } \\
\hline IMP/EXP & Constant used to calculate residential imports to and exports from reach \\
\hline TWITH & Total withdrawal from reach, hourly $\left(\mathrm{ft}^{3} / \mathrm{s}\right)$ \\
\hline WSPW & Total withdrawal satisfied by streamflow from reach, hourly $\left(\mathrm{ft}^{3} / \mathrm{s}\right)$ \\
\hline TRET & Total return to reach, hourly $\left(\mathrm{ft}^{3} / \mathrm{s}\right)$ \\
\hline SW-WTHDW & Individual surface-water withdrawal, daily $\left(\mathrm{ft}^{3} / \mathrm{s}\right)$ \\
\hline GW-WTHDW & Individual ground-water withdrawal (constant rate), daily ( $\left.\mathrm{ft}^{3} / \mathrm{s}\right)$ \\
\hline STRMDEPL & Individual stream depletion for time-varying ground-water withdrawal, daily $\left(\mathrm{ft}^{3} / \mathrm{s}\right)$ \\
\hline GC-WTHDR & Individual golf-course withdrawal, daily $\left(\mathrm{ft}^{3} / \mathrm{s}\right)$ \\
\hline RETURN & Individual wastewater return flow, daily $\left(\mathrm{ft}^{3} / \mathrm{s}\right)$ \\
\hline \multicolumn{2}{|r|}{$\begin{array}{l}\text { Flow or storage components from PERLNDs and IMPLNDs by drainage area to } \\
\text { streamflow-gaging stations for HSPEXP computations }\end{array}$} \\
\hline PERO & Total runoff (inches) \\
\hline SURO & Surface runoff (inches) \\
\hline IFWO & Interflow (inches) \\
\hline AGWO & Active ground-water flow (inches) \\
\hline UZSX & Upper-zone storage (inches) \\
\hline LZSX & Lower-zone storage (inches) \\
\hline PETX & Potential evapotranspiration (inches) \\
\hline SAET & Actual evapotranspiration (inches) \\
\hline SNOP & Total content of snowpack, water equivalent (inches) \\
\hline SNOM & Water yielded by snowpack to land surface (inches) \\
\hline
\end{tabular}




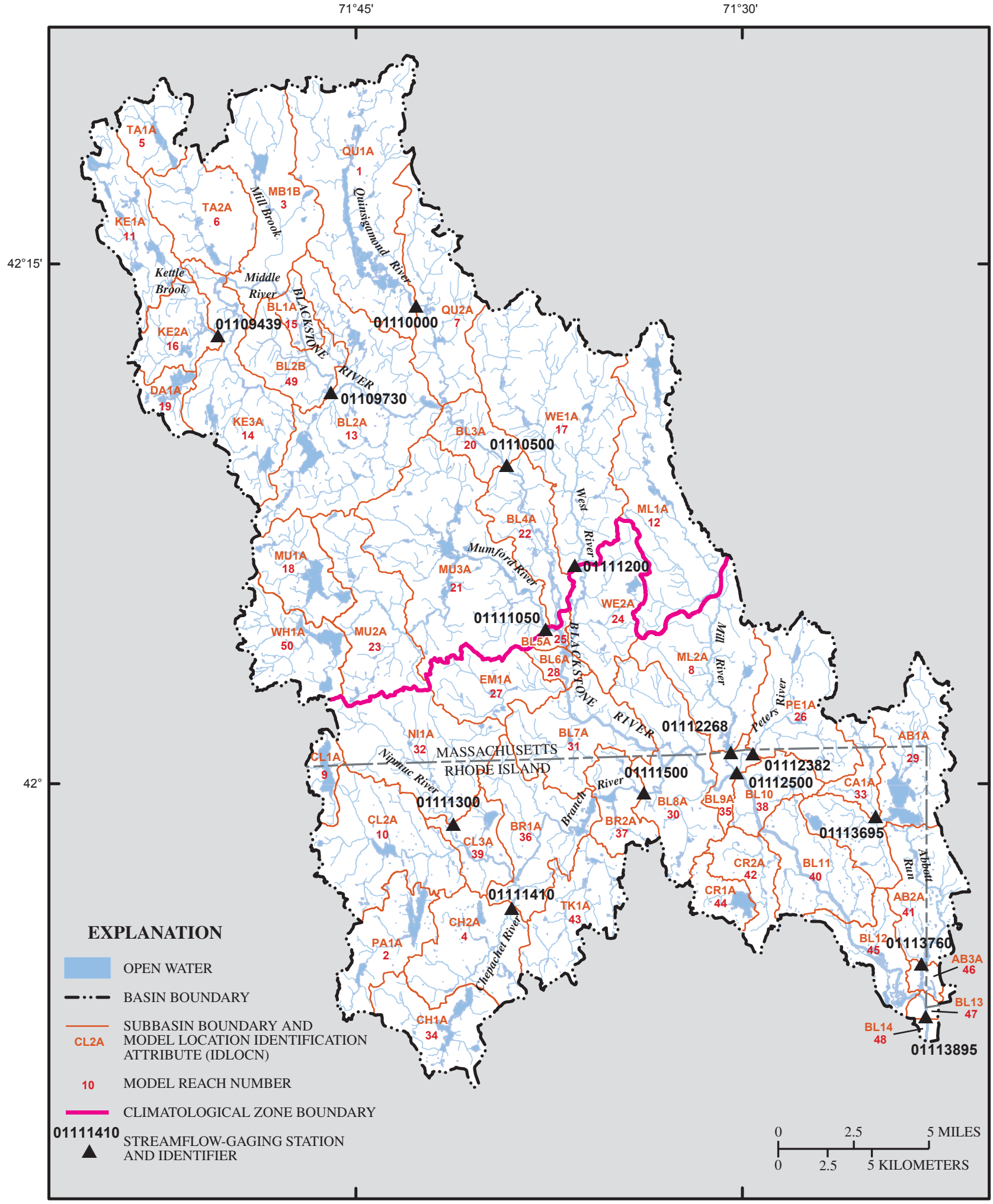

Base from U.S. Geological Survey, 1:24,000, 1995 Massachusetts state plane projection, NAD83

Figure 8. Model reaches, subbasin boundaries, and the boundary between climatological zones for the Hydrological Simulation Program-FORTRAN (HSPF) model for the Blackstone River Basin. 


\section{Water Withdrawals}

The water withdrawals simulated in the model include (1) the ground-water and surface-water withdrawals for municipal water supply and commercial/industrial uses, (2) ground-water and surface-water withdrawals for golfcourse irrigation, and (3) ground-water withdrawals from private wells in residential areas with public sewers. The municipal and commercial/industrial withdrawals are described in greater detail below. Golf-course withdrawals are discussed in the following section. A discussion of how the residential withdrawals are treated in the model in areas both with and without public sewers is provided in the "Representation of the Basin" section of the report.

Detailed ground-water and surface-water withdrawal data for municipal and commercial/industrial withdrawals were collected for 1996-2001 from a variety of sources. These sources include a water-use database (NEWUDS) populated by Barlow (2003) for the Blackstone River Basin, Annual Statistical Reports filed by public-water suppliers and provided by the MADEP, the Water Management Act database provided by the MADEP, and Water Supply System Management Plans filed by water suppliers in Rhode Island and provided by the RIWRB, or, in some cases, the water suppliers themselves. The 129 municipal and commercial/industrial withdrawals included in the model (including 18 withdrawals for golf-course irrigation that are described in detail in the following section) are shown in figure 9 and summarized in table 5. Of these withdrawals, 17 were from surface water and the remaining 112 were from ground water. Of the ground-water withdrawals, 96 were from the sand and gravel aquifer and 16 were from bedrock.

The information available from each source differed considerably and therefore required various degrees of processing to format the data for input into the model. Withdrawals from municipal wells in Massachusetts typically were reported as monthly totals; however, in some cases daily withdrawals were reported. Periods of missing record due to unavailability of withdrawal records or equipment problems were most frequent for municipal withdrawals in Rhode Island and commercial/industrial withdrawals. At five locations in Rhode Island (table 5, shaded rows), measured withdrawals were not available, and the population served by the supplier (Barlow, 2003) was used to estimate constant withdrawal rates for the calibration period. Values bracketing the period of missing record or average withdrawals for the period of missing record calculated from other years were used to estimate gaps in withdrawal records. Sixteen municipal and commercial/ industrial withdrawals in the model had periods of missing record requiring estimation.

Withdrawals reported as monthly totals were disaggregated to daily withdrawals before values were stored as a time series in the WDM file. Daily withdrawals from surface-water sources and ground-water sources in towns with a blend of surface-water and ground-water supplies were obtained by dividing by the number of days in the month. By contrast, daily withdrawals from wells in towns with only ground-water supplies were disaggregated by use of smoothed daily withdrawal records from wells in the town of Blackstone, Mass. The town of Blackstone, which obtains water from four wells adjacent to the Mill River, measured withdrawals on a daily basis for the entire calibration period. The total daily withdrawals from these wells averaged $0.74 \mathrm{Mgal} / \mathrm{d}$ for 1996-2001. Daily fluctuations in these withdrawals were considered to reflect day-to-day water-supply demands in other towns in response to variable climatological conditions. Town of Blackstone records were not used to estimate daily withdrawals from towns that use both ground-water and surface-water supplies, however, because in systems such as these, short-term increases in demand can be met from reservoir storage rather than increased well withdrawals.

The approach developed by Zarriello and Ries (2000) was used to smooth the town of Blackstone daily withdrawal record 1996-2001. To smooth the daily record, operationally related fluctuations in withdrawal rates were first removed by applying a 15-day moving average centered on the $8^{\text {th }}$ day of the interval to the raw data. The smoothing period was determined empirically to retain reasonably large variability in the daily values while reducing the large operational fluctuations. Daily withdrawals were then computed for 71 wells where only monthly withdrawals were available by (1) computing monthly mean withdrawals from the smoothed town of Blackstone daily withdrawals, (2) computing the ratio between the smoothed daily withdrawals and monthly mean withdrawals for each day for the town of Blackstone wells, (3) computing the average daily withdrawals by month for towns where only monthly withdrawals are available, and (4) multiplying the average daily withdrawals by the daily ratios computed from the town of Blackstone data (Zarriello and Ries, 2000).

\section{Golf-Course Withdrawals}

Irrigation withdrawals were calculated for the 18 golf courses in the basin (table 5). For most courses, information such as the number of irrigated acres, the source of irrigation water (for example, ground-water or surface-water withdrawals), and the volumes of water used for irrigation was not available. However, withdrawal data and the number of irrigated acres were available for six courses from the Massachusetts Water Management Act database. These measured withdrawals, which were reported as total annual volumes of water, were used to calibrate a procedure that was used to compute daily irrigation withdrawals at the golf courses in the basin. In the HSPF model, withdrawals for golf-course irrigation were assumed to be 100 percent consumed.

To compute daily irrigation withdrawals at the golf courses in the basin, a daily irrigation demand was determined from antecedent climatic conditions. The use of climatological data (precipitation and potential evapotranspiration) to determine an irrigation demand is consistent with the approach used by Zarriello and Bent (2004) in the Usquepaug-Queen Basin. In that study, a logistic-regression equation was developed from measured irrigation data. 


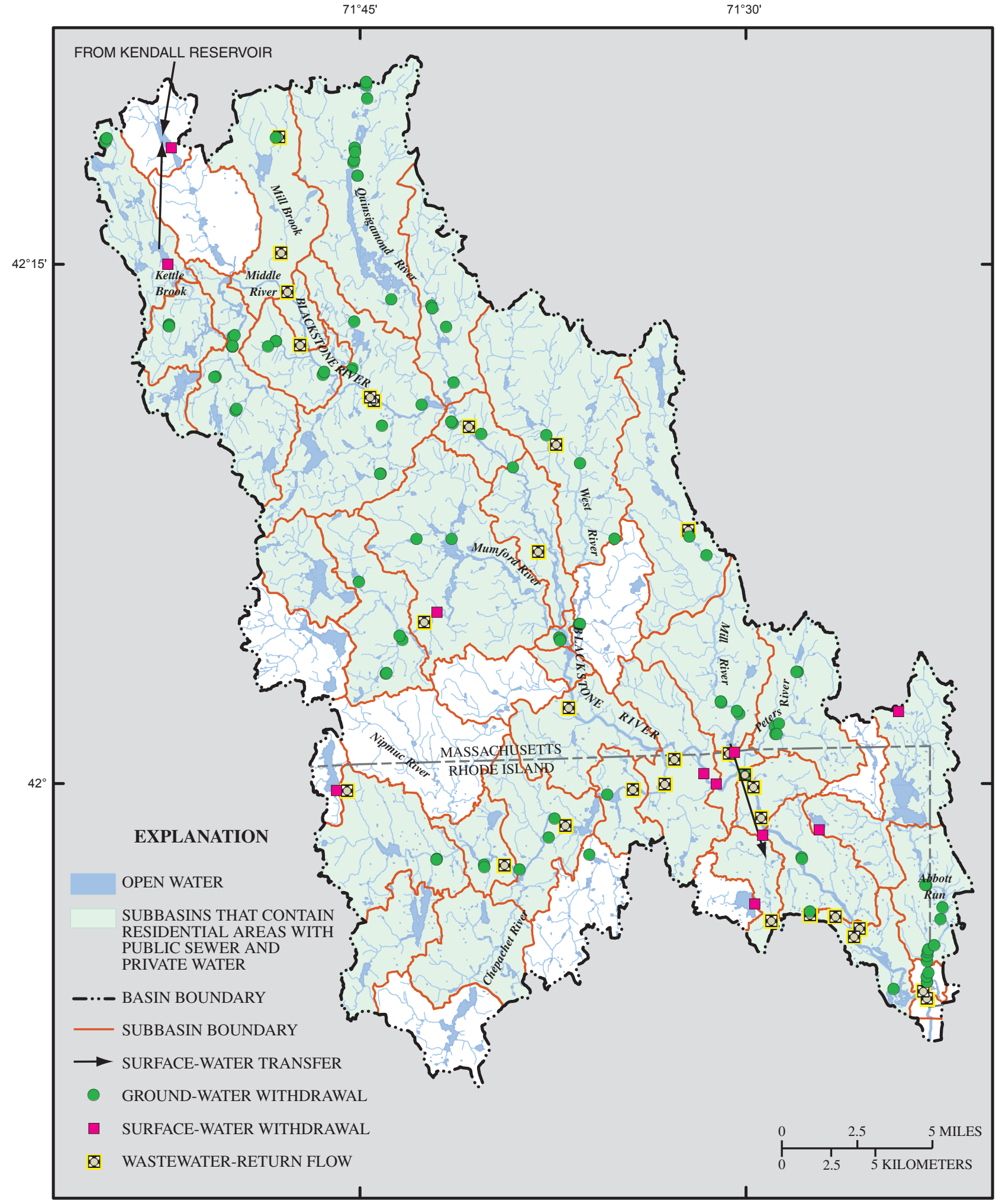

Base from U.S. Geological Survey, 1:24,000, 1995

Massachusetts state plane projection, NAD83

Figure 9. Locations of water withdrawals, transfers, and wastewater returns in the Blackstone River Basin. 
Table 5. Municipal, commercial/industrial, and golf-course withdrawals in the Blackstone River Basin, Massachusetts and Rhode Island.

[Aquifer refers to the geologic unit from which ground water was withdrawn. Distance to stream refers to the distance used to compute streamflow depletion for time-varying ground-water withdrawals. Shading indicates that streamflow depletion was not computed because only a constant ground-water withdrawal rate was available. WDM, watershed data management; DSN, dataset number; ft, feet; Mgal/d, million gallons per day; s\&g, sand and gravel aquifer; b, bedrock aquifer; - , not applicable because the withdrawal was from surface water; NA, not available]

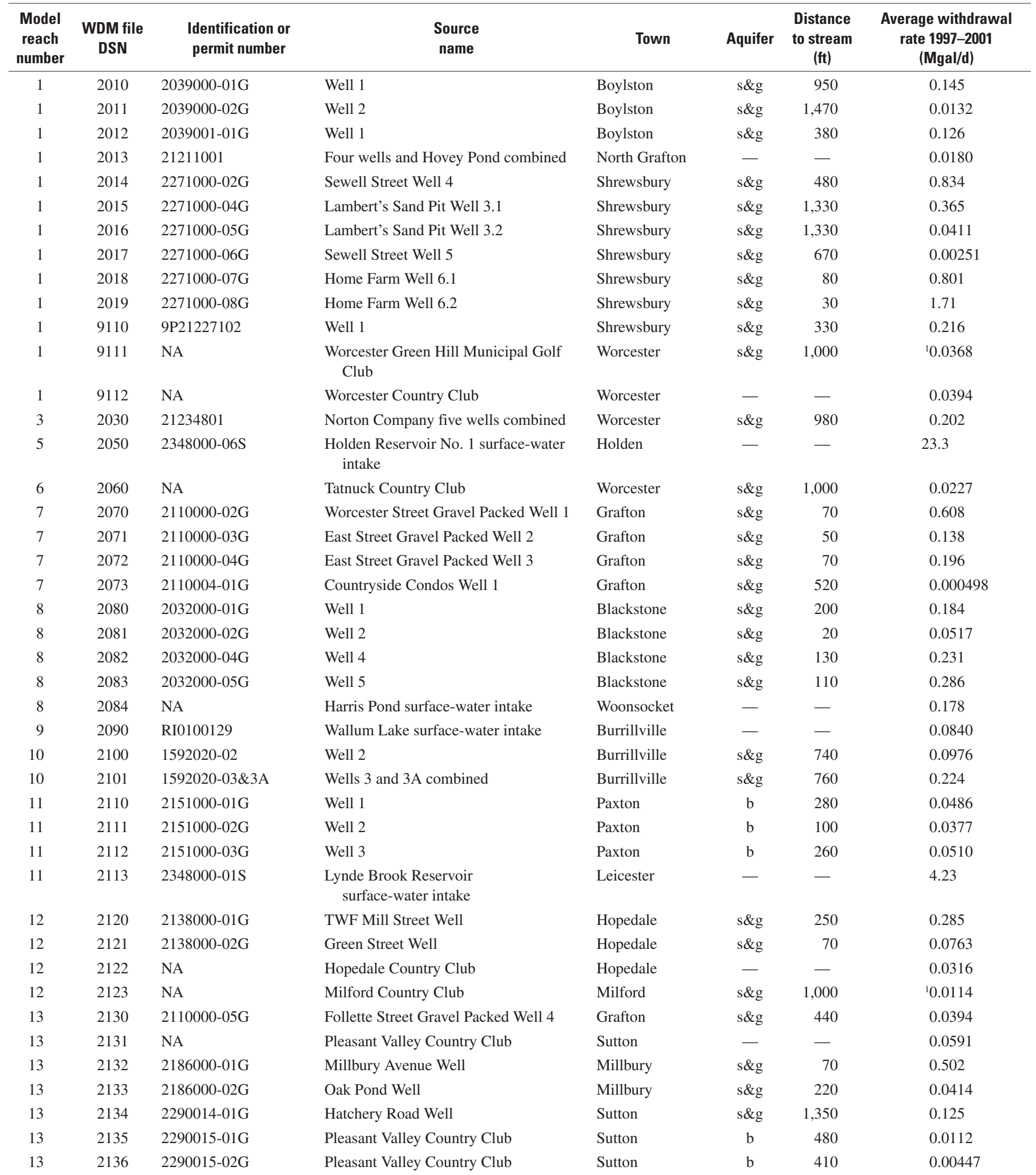


Table 5. Municipal, commercial/industrial, and golf-course withdrawals in the Blackstone River Basin, Massachusetts and Rhode Island.-Continued

[Aquifer refers to the geologic unit from which ground water was withdrawn. Distance to stream refers to the distance used to compute streamflow depletion for time-varying ground-water withdrawals. Shading indicates that streamflow depletion was not computed because only a constant ground-water withdrawal rate was available. WDM, watershed data management; DSN, dataset number; ft, feet; Mgal/d, million gallons per day; s\&g, sand and gravel aquifer; b, bedrock aquifer; - , not applicable because the withdrawal was from surface water; NA, not available]

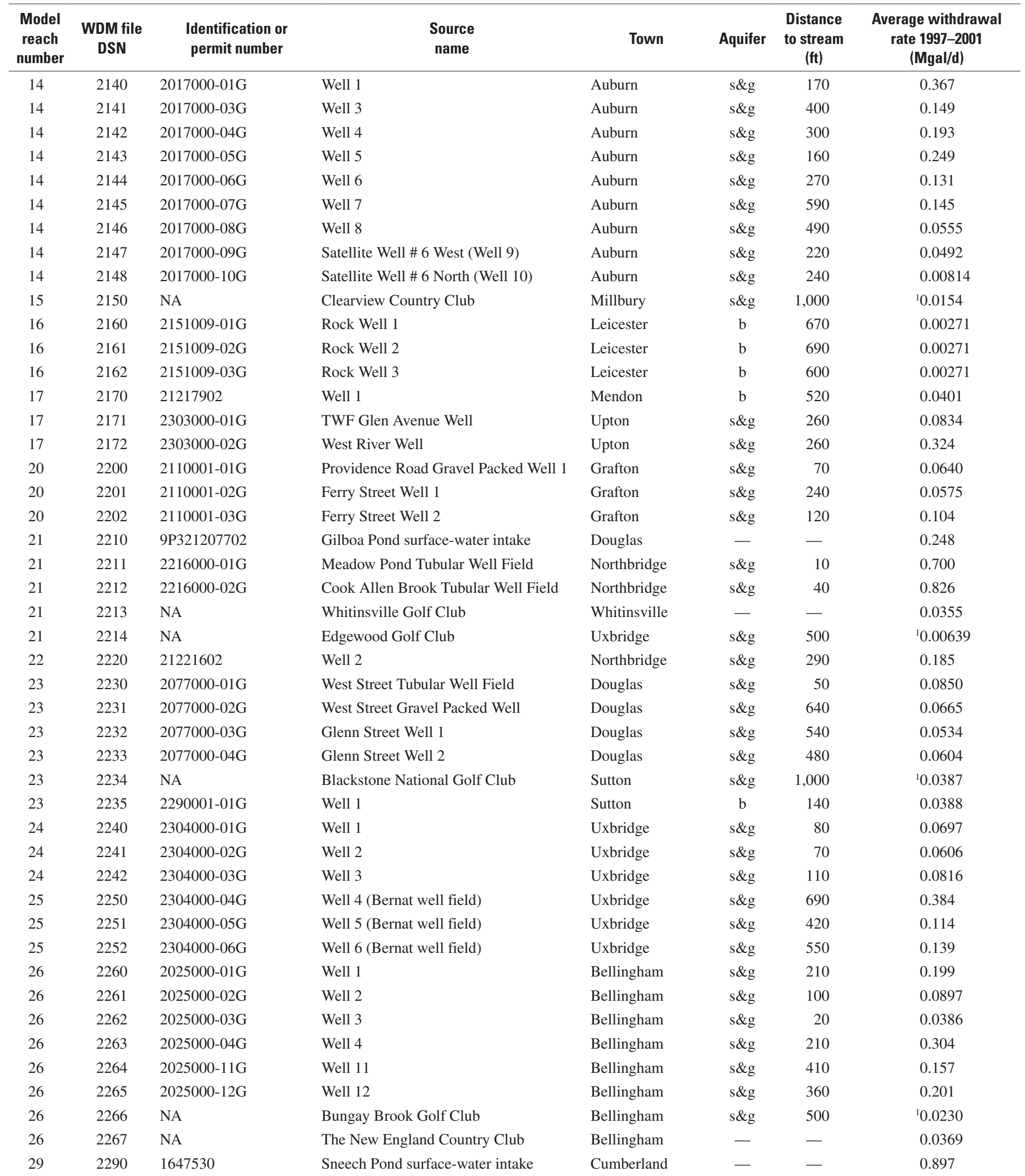


Table 5. Municipal, commercial/industrial, and golf-course withdrawals in the Blackstone River Basin, Massachusetts and Rhode Island.-Continued

[Aquifer refers to the geologic unit from which ground water was withdrawn. Distance to stream refers to the distance used to compute streamflow depletion for time-varying ground-water withdrawals. Shading indicates that streamflow depletion was not computed because only a constant ground-water withdrawal rate was available. WDM, watershed data management; DSN, dataset number; ft, feet; Mgal/d, million gallons per day; s\&g, sand and gravel aquifer; b, bedrock aquifer; - , not applicable because the withdrawal was from surface water; NA, not available]

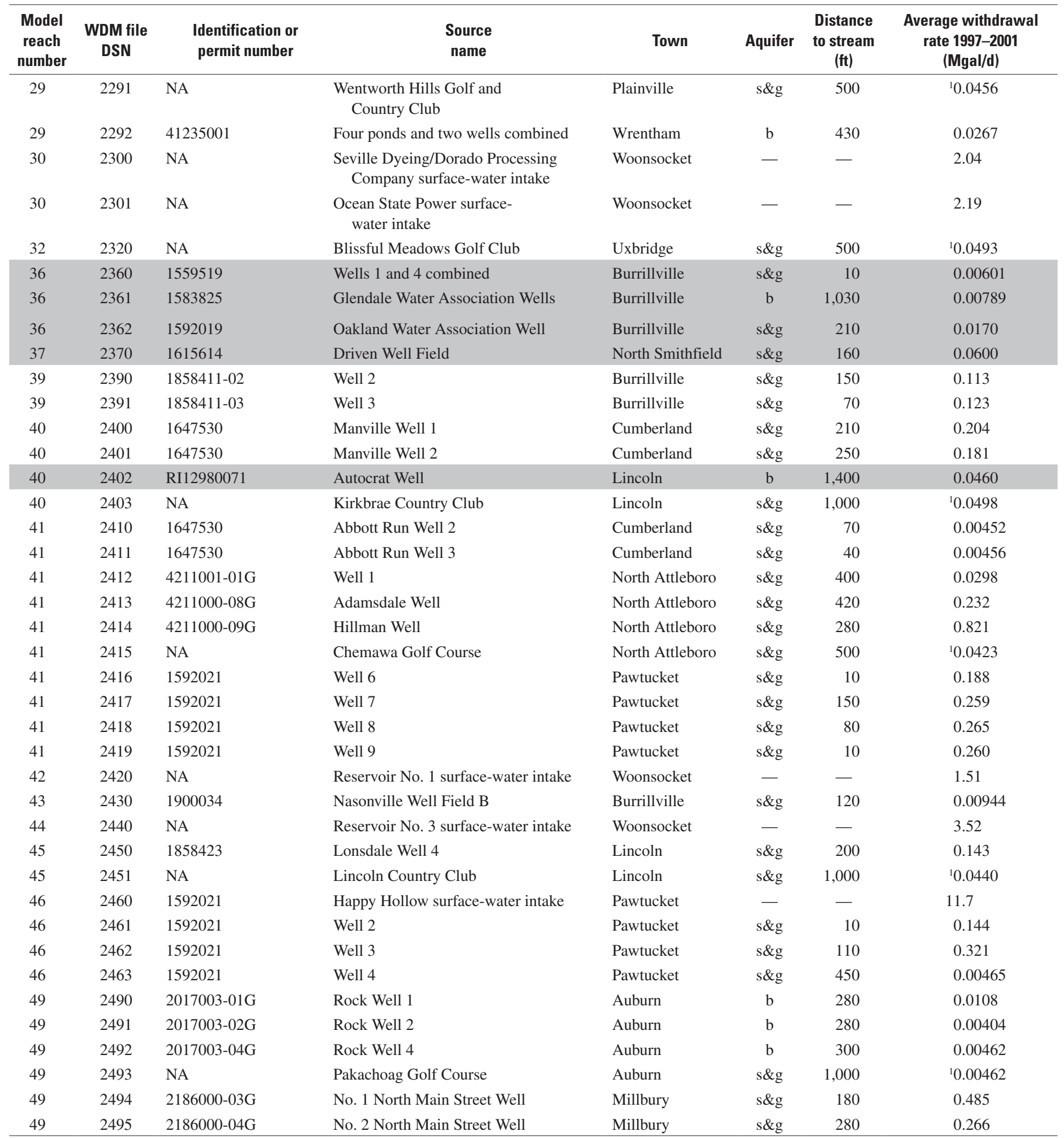

${ }^{1}$ Measured withdrawals not available. Withdrawals estimated as described in text. 
It was found that the total potential evapotranspiration in the previous 2 days, total potential evapotranspiration in the previous 20 days, and the total precipitation in the previous 10 days were the most significant explanatory variables for determining the probability of golf-course irrigation taking place on a specific day. To determine irrigation demand in the Blackstone River Basin, the Worcester climatic data were used for golf courses in the northern part of the basin, and the Warwick climatic data were used for the courses in the southern part of the basin.

To determine the irrigation demand, the climatologic variables were first adjusted to match the total annual volumes of water used for irrigation during 1996-2001 at the six courses with reported data. It was assumed that irrigation only took place from April and November (210 days). A reasonable combination was found to be 50 percent (an empirical adjustment factor) of the daily irrigation demand, where the irrigation demand was computed as the difference between the total precipitation in the previous 5 days and the total potential evapotranspiration in the previous 2 days. If the total precipitation in the previous 5 days exceeded the total potential evapotranspiration in the previous 2 days, irrigation was not applied. If, on the other hand, potential evapotranspiration exceeded precipitation, 50 percent of the difference was applied as irrigation for that day. The agreement between computed and observed annual irrigation volumes was improved further by adjusting the amount of irrigated acreage at each course. This was done because the year-to-year variability was reasonably represented, but the annual irrigation volumes were systematically too high or two low. The best-fit irrigated acreages were then used to calculate a ratio of irrigated acreage to golf-course size, represented by total yardage, for the six courses used in the calibration. This ratio was then applied to the other courses to determine the amount of irrigated acreage based on the size of the course. To develop time series for inclusion in the HSPF model, it was assumed that irrigation was applied at a constant rate for 24 hours on each day when irrigation took place.

This approach yielded temporally variable irrigation controlled by climate. For example, there were typically some long (2-3 week) stretches during the summer when there was no irrigation because of wet conditions. Although approximate, using climatic data to estimate periods of irrigation is more realistic than applying irrigation uniformly on a daily basis throughout the irrigation season. Because data were available to calibrate annual water use, this approach provided a reasonable estimate of total annual water use at each golf course. The median percent differences between observed and calculated annual volumes for the 6-year period for the six courses used in the calibration ranged from -2.0 percent to 24.2 percent. The total annual water use determined with the approach also is in reasonably good agreement with total use determined with irrigation water-use coefficients $(0.015 \mathrm{Mgal} / \mathrm{d} /$ irrigated acre and $0.012 \mathrm{Mgal} / \mathrm{d} / 1,000$ yards) developed by Barlow (2003) from an analysis of 70 golf courses in Massachusetts.

To prepare the golf-course withdrawal time-series records for inclusion in the HSPF model, it was necessary to determine whether withdrawals were directly from surface water or from ground water. Ground-water withdrawals were processed with the STRMDEPL program (described in the following section), and surface-water withdrawals were not modified. Water was obtained from unknown sources at five courses, from ground-water sources (typically from a mix of holding ponds and wells) at eight courses, and from surfacewater sources (typically from instream ponds or directly from larger rivers) at the remaining five courses. Because most of the courses are in upland areas where surface-water sources capable of providing adequate water are scarce, the source of water was assumed to be ground water at the 5 courses that had no information, resulting in calculation of stream depletion at 13 of 18 golf courses. Because the distances between the ground-water wells and the nearest streams typically were not known, an assumed distance of $500 \mathrm{ft}$ for courses in areas underlain by sand and gravel deposits and 1,000 ft for courses in areas underlain by till were used in the STRMDEPL program. A greater distance was used in till areas because these courses often are in upland areas where distances to the nearest stream are greater. All other STRMDEPL parameters were identical to those used for water-supply withdrawals.

\section{Streamflow Depletion by Ground-Water Withdrawals}

Streamflow depletion was determined for all time-varying ground-water withdrawals by use of the program STRMDEPL (Barlow, 2000). STRMDEPL produces a daily time series of the total streamflow depletion computed from the reported withdrawal record. Time series of streamflow depletion were computed from external to the HSPF program before the simulations were conducted. Streamflow-depletion time series for individual wells are included in the WDM file as DSN file numbers 2010 through 2495, 9110, 9111, and 9112 (table 5).

Total streamflow depletion has two components: captured (or intercepted) discharge, which is ground water that would have discharged to the stream had the well not been pumped, and induced infiltration, which is streamflow drawn out of the channel to the aquifer. Thus, the total volume of streamflow depletion under long-term, steady-state conditions is very close to the total volume pumped from the well; the main effect of STRMDEPL is to dampen the magnitude and timing of the time-varying pumping rate, which results from the diffusivity of the aquifer $(\mathrm{T} / \mathrm{S}$, where $\mathrm{T}$ is the transmissivity and $\mathrm{S}$ the storativity or specific yield) and the distance of the well from the stream. An example of streamflow depletion computed from daily withdrawals at King's Grant Water Company Well 1, $400 \mathrm{ft}$ from Abbott Run in North Attleboro, Mass., is shown in figure 10. STRMDEPL is based on several simplifying assumptions, including that the aquifer is homogeneous, isotropic and semi-infinite in areal extent, that both the stream and the well fully penetrate the aquifer, and that the stage of the stream remains constant with time. To simulate long-term operation and produce initial streamflow depletion similar to the pumping rate at the start of the calibration period, wells were allowed to pump for 5,000 days prior to the analysis. 


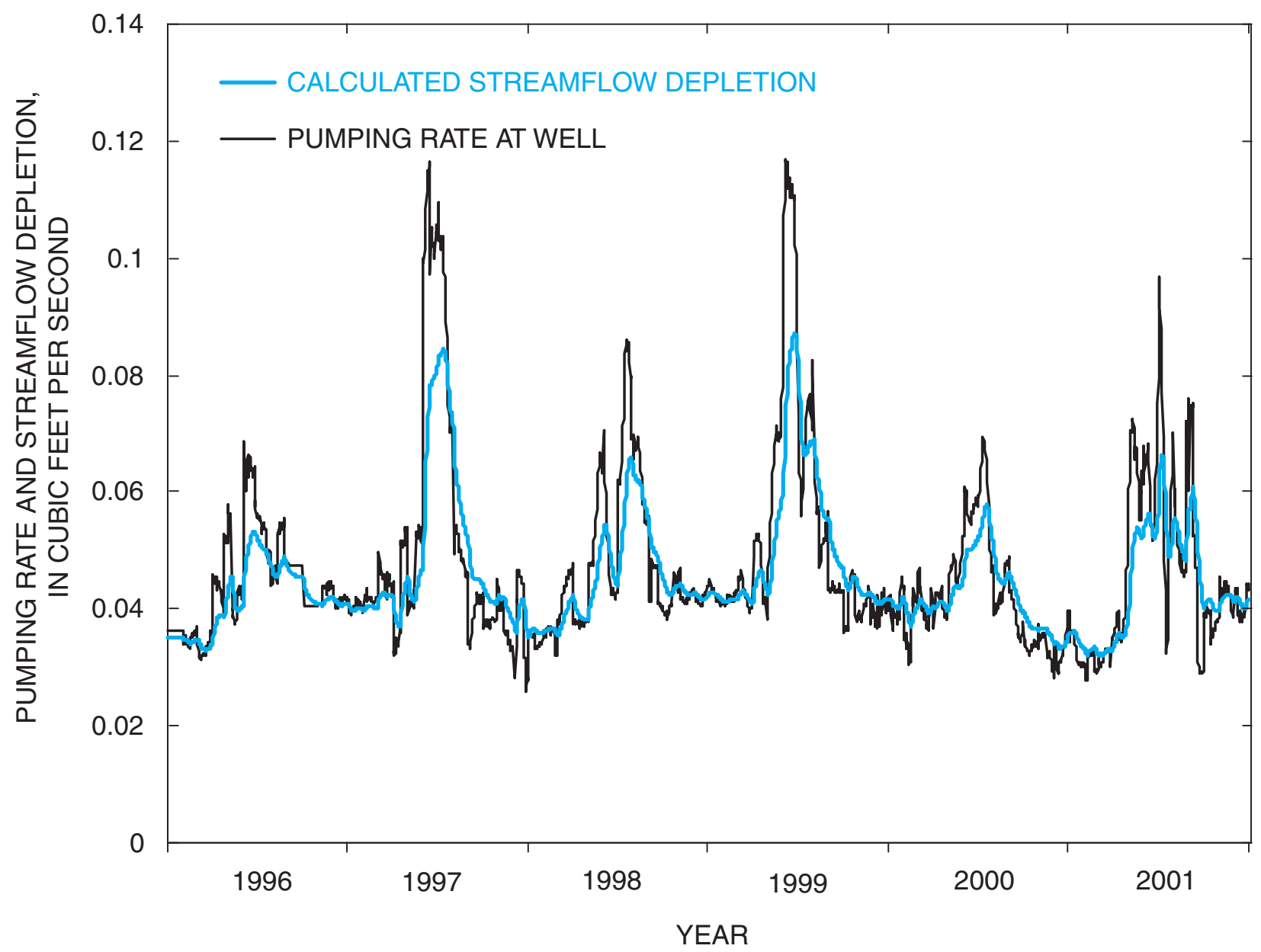

Figure 10. Daily withdrawal rate at King's Grant Water Company Well 1, North Attleboro, Massachusetts, 1996-2001, and calculated streamflow depletion.

STRMDEPL provides a direct measure of streamflow depletion caused by ground-water withdrawals. Therefore, although the actual locations of individual wells were used to calculate streamflow depletion, the withdrawals that result from the calculation are taken directly from the stream reach in the HSPF model. Streamflow depletion was computed for withdrawals from wells completed in bedrock and sand and gravel aquifers. Lithologic information was not readily available for most wells, so the surficial-geology data layer was used to determine whether the well was in an area underlain by till-mantled bedrock or unconsolidated sand and gravel deposits.

Most of the high-capacity wells are in sand and gravel aquifers near streams and induce infiltration from streams to improve yields. The median distance of the sand and gravel wells to the nearest stream was $255 \mathrm{ft}$ (table 5). Because sitespecific aquifer-thickness and lithologic data were not available for most of the wells in the model, a diffusivity value of $12,700 \mathrm{ft}^{2} / \mathrm{d}$ was used for all withdrawals in the sand and gravel aquifer, regardless of location. This value is based on a median transmissivity of $3,175 \mathrm{ft}^{2} / \mathrm{d}$ for the sand and gravel aquifer (from an analysis of 378 wells in the lower Blackstone River
Basin (P.E. Church, U.S. Geological Survey, written commun., 2005 ), and a specific yield of 0.25 . Streams underlain by sandand-gravel aquifers tend to have coarse streambed materials that do not limit the flux of water across the bed. The streambank leakance term was assigned a value of 0 , indicating that the bed of the stream has the same hydraulic properties as the aquifer, which is equivalent to assuming that low-permeability streambed deposits that may impede flow are not present.

Ground-water/surface-water interactions and aquifer properties are less well understood in upland areas underlain by till and bedrock than in the areas underlain by sand and gravel aquifers. Fourteen bedrock water-supply wells in the basin have time-variable withdrawals. Most are in upland areas where the rock is covered by till. Reported well depths range from 40 to $700 \mathrm{ft}$, but the depths are not known for most wells. The median distance of the bedrock wells included to the nearest stream was $420 \mathrm{ft}$ (table 5). Because fractured bedrock aquifers in Rhode Island and Massachusetts have very low storage, it may be reasonable to assume that streamflow responds instantaneously to time-variable pumping. However, upland streams typically are underlain by lower-permeability till deposits that will dampen time-variable pumping rates. 
Thus, STRMDEPL was run with a streambank leakance term that represents the thickness and hydraulic properties of this lower-permeability till. In applying STRMDEPL, it was assumed that shallow bedrock is sufficiently fractured to behave as a porous medium, and that the contributing area is sufficiently small to fall within the subbasin (that is, recharge from the unconsolidated overburden storage supplements small bedrock storage). Because the size and density of bedrock fractures decrease within the top $200 \mathrm{ft}$ (Randall and others, 1988), a thickness of $200 \mathrm{ft}$ was used to calculate the aquifer transmissivity. A diffusivity value of $1 \times 10^{6} \mathrm{ft}^{2} / \mathrm{d}$ was used for all wells in till-mantled bedrock areas. This value is based on a hydraulic conductivity (K) of $0.5 \mathrm{ft} / \mathrm{d}$, a thickness (b) of $200 \mathrm{ft}$, and a specific yield of $1 \times 10^{-4}$. A streambank leakance $\left(\mathrm{Kb}^{\prime} / \mathrm{K}^{\prime}\right)$ value of $500 \mathrm{ft}$ was used for all withdrawals, where b' is the thickness of the till streambank, and $\mathrm{K}^{\prime}$ is the hydraulic conductivity of the till. This value is based on a till thickness of $10 \mathrm{ft}$ and a till hydraulic conductivity of $0.01 \mathrm{ft} / \mathrm{d}$. Till thicknesses range from 10 to $30 \mathrm{ft}$ in southeastern New England, with locally thicker regions near drumlins and thinner regions near bedrock outcrops (Randall and others, 1988; Melvin and others, 1992a,b). The hydraulic conductivity of till can range over 4 orders of magnitude in New England; a value of $0.01 \mathrm{ft} / \mathrm{d}$ is representative of lower, compacted lodgement till (Randall and others, 1988).

\section{Wastewater-Return Flows}

Detailed wastewater return-flow information was collected for 1996-2001 from a variety of sources including NPDES databases maintained by the USEPA and RIDEM, the water-use database compiled by Barlow (2003), and directly from the treatment facilities. The return flows contained in the model include (1) municipal wastewater-return flows from the 10 municipal wastewater-treatment plants in the basin, (2) commercial and industrial return flows from permitted facilities, (3) filter-backwash return flows from municipal water-treatment plants, and (4) return flows of septic effluent from residential areas with public-water supplies and private sewers (septic systems). Municipal and commercial/industrial return flows are described in greater detail below. A discussion of how the septic-effluent discharges are treated in the model is provided in the "Representation of the Basin" section of the report.

The 29 municipal and commercial/industrial wastewaterreturn flows included in the model are shown in figure 9 and table 6. Approximately 15 additional commercial sites with discharge permits were excluded from the model because the sites were inactive during the calibration period, return-flow information could not be located, or the permits were for stormwater discharge only. The time intervals and amount of missing data varied considerably, and thus required various degrees of processing. Return flows from municipal wastewater-treatment plants were generally reported as daily or monthly totals. Return flows from commercial sites were reported as monthly, quarterly, or annual totals, and were missing more data than were municipal sites. Values bracketing the period of missing record, or average return flows for the period of missing record calculated from adjacent years were used to populate the data gaps. Wastewater return-flow records at 16 sites contained periods of missing record requiring estimation. To format the return flow data for input to the WDM file, annual, quarterly, and monthly returns were disaggregated to daily values by assuming a constant daily return flow and dividing by the number of days in the reported period. All daily values were disaggregated further to hourly values by assuming a constant hourly rate within a given day.

\section{Streamflow}

The stations in the Blackstone River Basin that have measured streamflow for the calibration period include Quinsigamond River at North Grafton, Mass. (station no. 01110000); Blackstone River at Northbridge, Mass. (station no. 01110500); West River at Uxbridge, Mass. (station no. 01111200); Nipmuc River near Harrisville, R.I. (station no. 01111300); Branch River at Forestdale, R.I. (station no. 01111500); and Blackstone River at Woonsocket, R.I. (station no. 01112500) (fig. 4). At the West River at Uxbridge, Mass. station, stage data were collected but mean daily discharges were not published by the USGS for 1997-2001, so discharge for this period was computed in 2004 to obtain additional data for model calibration. Records at the Quinsigamond River, Nipmuc River, Branch River, and Blackstone River at Woonsocket stations are rated as good (95 percent of daily discharges are within 10 percent of the true value).

Records at the Blackstone River at Northbridge also are rated as good; however, the rating curve below about $300 \mathrm{ft}^{3} / \mathrm{s}$ is considered poor because of variable backwater conditions created by downstream flow regulation. Flows are typically below $300 \mathrm{ft}^{3} / \mathrm{s}$ in the summer and fall. Observed flow data are in DSN numbers 30 through 92 in the WDM file.

At the remaining stations in the Blackstone River Basin (the 7 project stations and the Blackstone River at Millbury, Mass. station, also referred to as partial-record stations), record-extension techniques were used to compute streamflow for 1997-2001. These techniques involve correlating the measured streamflow at the project stations (continuous record collected mainly during the 2004 water year) with streamflow from nearby stations (also referred to as continuous-record stations) that have a measured streamflow record for 1997-2001, which include stations in the Blackstone River Basin and seven other stations in surrounding drainage basins. The stations used in the analysis are shown in figure 4. Streamflow at the Kettle Brook at Auburn, Mass. (station no. 01109439); Mumford River at Uxbridge, Mass. (station no. 01111050); Chepachet River at Gazzaville, R.I. (station no. 01111410); Mill River at Woonsocket, R.I. (station no. 01112268); Peters River at Woonsocket, R.I. (station no. 01112382); Abbott Run at Valley Falls, R.I. (station no. 01113760); and Blackstone River at Pawtucket, R.I. (station no. 01113895) stations was estimated for 1997-2001 by using a mathematical procedure known as Maintenance of Variance Extension, type 1 (MOVE.1) (Hirsch, 1982). 
Table 6. Wastewater-return flows in the Blackstone River Basin, Massachusetts and Rhode Island.

[WDM, watershed data management; DSN, dataset number; Mgal/d, million gallons per day]

\begin{tabular}{|c|c|c|c|c|c|}
\hline $\begin{array}{l}\text { Model } \\
\text { reach } \\
\text { number }\end{array}$ & $\begin{array}{l}\text { WDM file } \\
\text { DSN }\end{array}$ & $\begin{array}{l}\text { Identification or } \\
\text { permit number }\end{array}$ & Source name & Town & $\begin{array}{c}\text { Average return rate } \\
\text { 1997-2001 } \\
\text { (Mgal/d) }\end{array}$ \\
\hline 3 & 3030 & MA0000817 & Norton Company & Worcester & 0.148 \\
\hline 3 & 3031 & MA0102997 & Worcester Combined Sewer Overflow Plant & Worcester & 1.06 \\
\hline 3 & 3032 & MA0001112 & Wyman Gordon & Worcester & 0.350 \\
\hline 10 & 3100 & RI0100129 & Eleanor Slater Hospital, Zambarano Unit & Burrillville & 0.0688 \\
\hline 12 & 3120 & MA0102202 & Hopedale Wastewater-Treatment Plant & Hopedale & 0.389 \\
\hline 13 & 3130 & MAG250969 & Lewcott Corporation & MIllbury & 0.0098 \\
\hline 13 & 3131 & MA0100650 & Millbury Wastewater-Treatment Plant & Millbury & 1.06 \\
\hline 15 & 3150 & MA0102369 & $\begin{array}{l}\text { Upper Blackstone Water Pollution } \\
\text { Abatement District }\end{array}$ & Millbury & 35.4 \\
\hline 17 & 3170 & MA0100196 & Upton Wastewater-Treatment Plant & Upton & 0.180 \\
\hline 20 & 3200 & MA0101311 & Grafton Wastewater-Treatment Plant & Grafton & 1.52 \\
\hline 21 & 3210 & MA0101095 & Douglas Wastewater-Treatment Plant & Douglas & 0.180 \\
\hline 22 & 3220 & MA0100722 & Northbridge Wastewater-Treatment Plant & Northbridge & 1.30 \\
\hline 30 & 3300 & RI0000566 & Atlantic Thermoplastics Company, Incorporated & North Smithfield & 0.00115 \\
\hline 30 & 3301 & RI0000485 & Blackstone Smithfield Corporation & North Smithfield & 0.00313 \\
\hline 31 & 3310 & MA0102440 & Uxbridge Wastewater-Treatment Facility & Uxbridge & 0.712 \\
\hline 35 & 3350 & RI0021466 & CNC International & Woonsocket & 0.0499 \\
\hline 36 & 3360 & RI0000116 & Turex Incorporated & Burrillville & 0.00595 \\
\hline 37 & 3370 & RI0000019 & Philips Components & North Smithfield & 0.00297 \\
\hline 38 & 3380 & RI0021393 & ACS Industries Incorporated & Woonsocket & 0.204 \\
\hline 38 & 3381 & RI0100111 & Woonsocket Wastewater-Treatment Facility & Woonsocket & 9.06 \\
\hline 38 & 3382 & RI0001627 & Woonsocket Water Division (filter backwash) & Woonsocket & 0.963 \\
\hline 39 & 3390 & RI0100455 & Burrillville Wastewater-Treatment Facility & Burrillville & 0.804 \\
\hline 42 & 3420 & RI0000124 & A.T. Cross, Outfall 001 & Lincoln & 0.0906 \\
\hline 45 & 3450 & RI0020451 & Air Products and Chemicals Incorporated & Cumberland & 0.130 \\
\hline 45 & 3451 & RI0020141 & Okonite Company & Cumberland & 0.114 \\
\hline 45 & 3452 & RI0021865 & Fleet National Bank & Lincoln & 0.000123 \\
\hline 45 & 3453 & RI0023132 & Blackstone Valley Electric Company & Lincoln & 0.00360 \\
\hline 46 & 3460 & RI0001589 & Pawtucket Water Supply Board (filter backwash) & Cumberland & 0.277 \\
\hline 47 & 3470 & RI0001180 & Osram Sylvania & Central Falls & 0.325 \\
\hline
\end{tabular}

The MOVE. 1 procedure transfers the statistical characteristics of the continuous-record station, such as distribution shape, seasonality, and amount of serial correlation, to the project station. To apply this method, the logarithms of daily mean streamflow at the project stations were compared with the same-day daily mean streamflow at the selected continuousrecord stations for the common period of record, generally the 2004 water year. Continuous-record stations were selected based on (1) the correlation and linearity of the log-transformed data and (2) visual inspection of the agreement between the measured and computed 2004 water-year hydrographs. The continuous-record stations and methods used to estimate streamflow are summarized in table 7.

Scatter plots show that the relations between logarithms of streamflow at the project and continuous-record stations are linear for all project stations except Abbott Run at Valley Falls, R.I., and Mill River at Woonsocket, R.I. At these stations, two distinct linear segments were present on one or more of the scatter plots of the log-transformed daily mean streamflow, so a model in which a unique MOVE.1 equation was applied to each straight-line segment (referred to in this study as a two-slope model) was used (table 7). After the MOVE. 1 procedure was applied to the common 2004 data, daily mean streamflows for 1997-2001 were computed for each project station from the streamflow data collected at each of the selected continuous-record stations. If flow at a project station correlated equally well with more than one continuousrecord station (for example, Kettle Brook at Auburn, Mass., in table 7), all of the highly correlated continuous-record stations were used to estimate flow, rather than arbitrarily select one station from the group. In these cases, the daily mean streamflow at each project station was computed by a weighed average of the daily mean streamflows calculated for each continuous-record station, where each continuous-record station streamflow was weighted on the basis of the mean square error between the computed streamflow and the measured streamflow at the project streamflow-gaging station. 


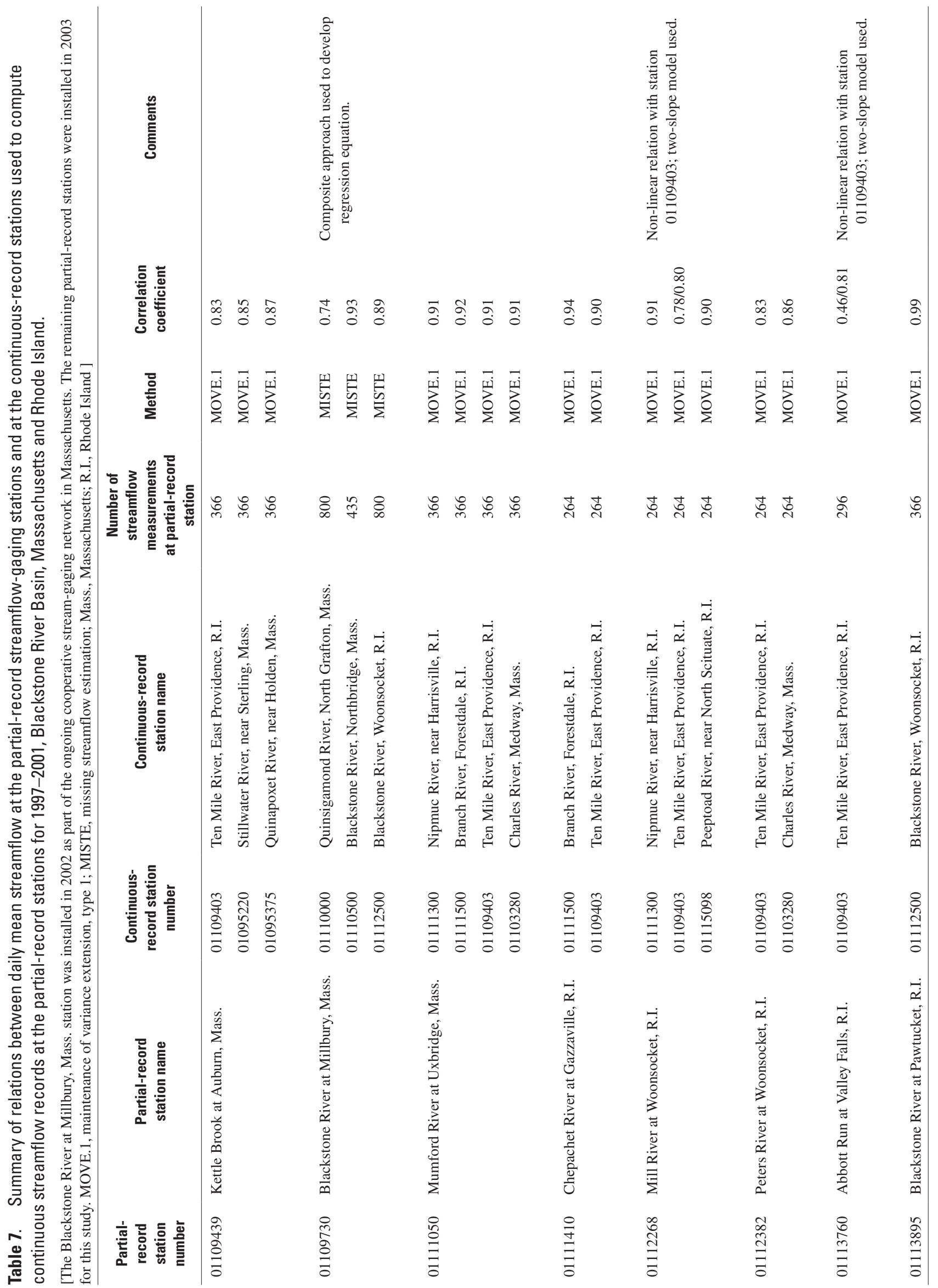


Streamflow was computed for the Blackstone River at Millbury, Mass. (station no. 01109730) station by use of the MIssing STreamflow Estimation (MISTE) program contained in the USGS Automated Data Processing System (ADAPS) database. MISTE is a multi-variant regression procedure developed to compute periods of missing data from the relation of flows to user-selected index stations for common periods of streamflow-data collection. MISTE allows lag periods and multiple index stations to be incorporated into the regression to improve the agreement between computed and observed flows.

Streamflow at the Millbury, Mass. station is strongly affected by wastewater-return flows and the amount of upstream urban land use, so a composite approach involving empirical adjustments to the computed record was needed to develop a reasonable estimate of streamflow. MISTE was used initially to compute flows from log-transformed data from the Blackstone River at Woonsocket, R.I. station with a 1-day lag (hereafter referred to as the Woonsocket equation). A 1-day lag in the Woonsocket streamflow data was tested in the regression analysis because the site is $28 \mathrm{mi}$ downstream from the Millbury station. Estimates of streamflow at the Blackstone River at Millbury, Mass. station also were obtained from the Blackstone River at Northbridge, Mass. station only with no lag (hereafter referred to as the Northbridge equation), and the Northbridge and Quinsigamond River at North Grafton, Mass. stations combined with no lag (hereafter referred to as the Northbridge-Quinsigamond equation). Visual inspection of the computed streamflow at Millbury during the period when the Northbridge streamflow-gaging station was concurrently operated (July 25, 2002 through September 30, 2003) indicated that both equations (Northbridge and NorthbridgeQuinsigamond) appreciably overestimated low flows. This is believed to be caused by the poor rating at the Northbridge station during low flows because of variable backwater conditions. The Northbridge-Quinsigamond equation provided a better estimate of peak flows than the Woonsocket equation because the Northbridge and Quinsigamond stations are closer to the Millbury station and are less dampened than the flows at the Woonsocket station. Neither equation (Woonsocket or Northbridge-Quinsigamond) captured the flashiness of the streamflow at the Millbury station, which is believed to result from the presence of the city of Worcester above the station.

Combining the Woonsocket and the Northbridge-

Quinsigamond equations provided a better estimate of streamflow at the Millbury station than either of these equations alone. The combined estimation entailed using an empirically adjusted peak flow from the Northbridge-Quinsigamond equation and non-peak flows from the Woonsocket equation. The peak flows from the Northbridge-Quinsigamond equation were adjusted by a factor determined from the median difference between the estimated and observed flow from the common period of record. The differences between the estimated and observed flows generally were greatest during the observed peak; the estimated peak flows were underpredicted by a median difference of 61 percent. If flows on a given day exceeded the flow 2 days previously by 50 percent, and if that day's flow was at the end of a rising hydrograph, the peak flow for that day was estimated by the Northbridge-Quinsigamond equation multiplied by an adjustment factor 1.61. Flow on the following day was estimated by the Northbridge-Quinsigamond equation. For all other days, the flow at the Millbury station was estimated by the Woonsocket equation. The root mean square error calculated from estimated and observed flows from the Woonsocket equation, the Northbridge-Quinsigamond equation, and the combined equation, was 76, 60, and $50 \mathrm{ft}^{3} / \mathrm{s}$, respectively.

The accuracy of these record-extension techniques is determined by the degree of correlation between the daily mean streamflows at the partial-record (project stations and Blackstone River at Millbury, Mass. station) and continuousrecord streamflow-gaging stations, the accuracy of the continuous-discharge records, and the range of measured flows at the project streamflow-gaging stations (Zarriello and Bent, 2004). Because of the short period of record at the partialrecord stations, a wide range of flow conditions was not measured and estimates of daily mean streamflows at both high and low flows are less accurate. In addition, flow regulation may affect specific ranges of flows in the partial- and continuous-record stations, leading to additional error in the computed record. Because each of these factors introduces uncertainty, computed streamflow records at the partial-record stations are considered estimates. Based on visual inspection of computed and measured hydrographs for the 2004 water year and the correlation coefficients shown in table 7, the computed streamflow record for 1997-2001 is qualitatively considered very good at the Blackstone River at Pawtucket, R.I. station, good at the Blackstone River at Millbury, Mass., Mumford River at Uxbridge, Mass., and Chepachet River at Gazzaville, R.I. stations, and fair at the Kettle Brook at Auburn, Mass., Peters River at Woonsocket, R.I., Mill River at Woonsocket, R.I., and Abbott Run at Valley Falls, R.I. stations.

\section{Representation of the Basin}

The physical and spatial representation of the basin is defined by the combination of HRUs (PERLNDs and IMPLNDs), their contributing area to a reach, and the linkage of one stream reach to another. The process of defining HRUs, their linkage to reaches, and the linkage of reaches to each other often is referred to as the discretization of a basin. A geographicinformation system (GIS) was used to discretize the Blackstone River Basin. Basin and subbasin boundaries in the model study area were obtained from available USGS, Massachusetts Geographic Information System (MassGIS), and Rhode Island Geographic Information System (RIGIS) sources (Massachusetts Geographic Information System, 2003 and Rhode Island Geographic Information System, 2003) or digitized from 1:24,000-scale USGS topographic maps when necessary. The data layers used in the discretization process include surfi- 
cial geology, land use, wetlands, and the distribution of public water supply and public sewer systems.

\section{Data Layer Processing and Basin Simplification}

Processing of digital data layers used for HRU development and the simplifications to the representation of the basin in the model are described in this section. Spatial data from Massachusetts and Rhode Island were generally reclassified to produce consistent basinwide data layers, and then simplified to obtain categories that were considered important to the basin hydrology and HRU development.

\section{Surficial Geology}

The surficial-geology data layers from MassGIS and RIGIS were simplified from four types of material (sand and gravel, alluvium, till, and bedrock) into two types (sand and gravel and till) on the basis of permeability and storage characteristics. Bedrock outcrops and alluvial deposits are not areally extensive in the basin, and therefore, were not considered explicitly for HRU development. Consequently, areas underlain by bedrock were combined with till, and areas underlain by alluvium were combined with sand and gravel.

\section{Land Use and Land Cover}

LULC information was obtained from the MassGIS and RIGIS Web sites. The MassGIS data layer represents land use in 1999 and has 37 land-use classifications interpreted from 1:25,000 aerial photography (Massachusetts Geographic Information System, 2003). The minimum mapping unit (resolution) used was 1 acre. The Rhode Island data layer represents land use in 1995 and has 34 land-use classifications, with a minimum resolution of 0.5 acre (Rhode Island Geographic Information System, 2003). To produce consistent LULC categories for the entire basin, the Massachusetts and Rhode Island data layers were reclassified to a common classification system and then combined to produce a data layer for the basin. This data layer was then intersected with a basinwide wetlands data layer developed from Massachusetts and Rhode Island wetland data layers to produce a composite cover consisting of 20 LULC categories. To represent land use in the model, the 20 LULC categories were simplified further into 7 LULC categories: (1) commercial-industrial-transportation, (2) high-density residential, (3) medium- to low-density residential, (4) open non-residential, (5) forest, (6) forested and non-forested wetlands, and (7) open water (fig. 2).

The simplified LULC data indicates that 50.7 percent of the basin is forested, excluding forested wetlands which are accounted for in the wetlands category. If forested wetlands are included in the forest category, 56 percent of the basin is forested. An additional 10.7 percent of the basin is classified as open, non-residential land. This mixed category includes developed recreational spaces, urban open spaces, cemeteries, orchards and nurseries, and other agricultural lands such as hay fields and cropland. Wetlands, including both forested and non-forested, compose 7.7 percent of the basin area. Approximately 5.8 percent of the basin is classified as commercialindustrial-transportation. This mixed category includes all roads and transportation facilities, manufacturing and warehouse facilities, landfills, wastewater-treatment plants, junkyards, and quarries. About 3.8 percent of the basin is classified as open water, which includes ponds, reservoirs, and the larger river channels.

The remaining 21.3 percent of the basin is classified as residential, of which 14.7 percent is medium- to low-density residential and 6.6 percent is high-density residential. To obtain these percentages, the Massachusetts and Rhode Island residential land-use categories were reclassified to a common system consisting of four categories: (1) high-density residential $(<1 / 8$-acre lots, multifamily), (2) medium-high density residential (1/8to $1 / 4$-acre lots), (3) medium-density residential (1/4- to 1-acre lots), and (4) low-density residential (>1-acre lots) (table 8). Each of these categories was assigned an average household density per acre based on lot size, and an average population

Table 8. Residential densities used in the Hydrological Simulation Program-FORTRAN (HSPF) model of the Blackstone River Basin, Massachusetts and Rhode Island.

[HRU, Hydrologic Response Unit; <, less than; >, greater than]

\begin{tabular}{|c|c|c|c|c|c|c|}
\hline $\begin{array}{c}\text { Reclassified residential catego- } \\
\text { ries from state } \\
\text { land-use data layers }\end{array}$ & $\begin{array}{l}\text { Number of } \\
\text { households } \\
\text { per acre }\end{array}$ & $\begin{array}{l}\text { Population } \\
\text { per acre }\end{array}$ & $\begin{array}{l}\text { Consolidated } \\
\text { residential categories } \\
\text { for HRU development }\end{array}$ & $\begin{array}{l}\text { Percentage of } \\
\text { consolidated } \\
\text { residential area }\end{array}$ & $\begin{array}{l}\text { Weighted } \\
\text { number of } \\
\text { households } \\
\text { per acre }\end{array}$ & $\begin{array}{c}\text { Weighted } \\
\text { population } \\
\text { per acre }\end{array}$ \\
\hline $\begin{array}{l}\text { High-density residential } \\
\qquad(<1 / 8 \text {-acre lots })\end{array}$ & 8 & 20 & High-density residential & 24.1 & 5.7 & 14.3 \\
\hline $\begin{array}{l}\text { Medium-high density residential } \\
\text { (1/4- to } 1 / 8 \text {-acre lots) }\end{array}$ & 5 & 12.5 & & 75.9 & & \\
\hline $\begin{array}{l}\text { Medium-density residential } \\
\text { (1/4- to } 1 \text {-acre lots) }\end{array}$ & 2.5 & 6.3 & $\begin{array}{l}\text { Medium- to low- } \\
\text { density residential }\end{array}$ & 49.8 & 1.5 & 3.7 \\
\hline $\begin{array}{l}\text { Low-density residential } \\
\quad(>1 \text {-acre lots })\end{array}$ & 0.5 & 1.3 & & 50.2 & & \\
\hline
\end{tabular}


density per acre using an average of 2.5 people per household obtained from 2000 census data (U.S. Census Bureau, 2005). These categories were then consolidated again by adding high density and medium-high density together and medium-density and low-density together, forming the two residential landuse categories, high-density residential and medium- to low-density residential, used in HRU development (table 8). Grouped in this manner, medium- to low-density residential areas represent single-family households on lots with areas equal to or larger than $1 / 4$ acre.

An average household density per acre for each of these final residential land-use categories was then calculated as a weighted average of the household densities in the reclassified state residential categories that were grouped together to form these categories. For instance, the final high-density residential area consists of 24.1 percent high-density residential and 75.9 percent medium-high density residential land use, so the household density of the medium-high density residential land use was given greater weight. Based on this analysis, the high-density residential areas and medium- to low-density residential areas contain an average of 5.7 households per acre and 1.5 households per acre, respectively. Based on 2.5 people per household on average, these housing densities equate to 14.3 people per acre in high-density residential areas and 3.7 people per acre in medium- to low-density residential areas. The total estimated population in the basin resulting from these residential population densities and corresponding land areas was 453,300. The total population in the basin in 2000 determined from U.S. census block data was 467,200 (U.S. Census Bureau, 2004a,b). The difference between these population estimates is 3 percent, and the close agreement indicates that residential land use and population are reasonably well represented in the model.

\section{Wetlands}

Wetland areas were obtained from MassGIS and RIGIS for the Massachusetts and Rhode Island parts of the basin, respectively. Wetlands in Rhode Island were interpreted from 1988 aerial photography to 1/4-acre polygon resolution (Rhode Island Geographic Information System, 2003). Wetlands in Massachusetts were interpreted from 1992 aerial photography using a classification scheme consisting of 28 wetland categories (Massachusetts Geographic Information System, 2003). The two data layers were simplified into forested and non-forested wetlands and then combined to produce a consistent wetlands data layer for the basin. Wetlands were simplified further for model development by combining forested and non-forested wetlands into a single land-use type.

\section{Public Water and Public Sewer Systems}

To represent water use in the model, a data layer showing the distribution of public water and public sewer systems was compiled (fig. 6). In this report, public systems refer to municipal distribution and collection systems associated with major water suppliers and regional wastewater-treatment plants, respectively. In Rhode Island, sewer-line and water-line data were obtained from RIGIS (Rhode Island Geographic Information System, 2003) and from individual towns (Burrillville, North Smithfield, and Woonsocket). In Massachusetts, data were obtained from the Central Massachusetts Regional Planning Commission and individual towns. A basinwide map of sewer lines was then generated by digitizing the individual sewer maps provided by the towns as necessary, and then combining all digital data from Rhode Island and Massachusetts on a single data layer. The same procedure was used to develop a basin-scale map of water lines. These maps generally represent the extent of public sewer and public water systems in the basin for 1995-2003. Polygon data layers of sewer and water areas were then generated from the sewer-line and water-line data layers by creating a 1,000-ft buffer zone (500 ft per side) around each line. Finally, a combined data layer was developed for the entire basin by combining the sewer-area and water-area data layers with the basin polygon. The resulting data layer was coded so that the entire basin area was represented by one of four possible water-sewer infrastructure combinations. These combinations are: (1) areas with private water (private wells) and private sewers (on-site septic systems) (code 1), (2) areas with private water and public sewers (code 2), (3) areas with public water and private sewers (code 3), and (4) areas with public water and public sewers (municipal water-supply distribution and wastewater-collection systems) (code 4).

When the combined public-water and public-sewer data layer was intersected with the reclassified land-use data layer, the areal extent of the four possible water-sewer infrastructure combinations listed above for each residential land-use category was determined. The areas of these infrastructure combinations were computed for both the medium- to low-density residential areas and the high-density residential areas and used to develop PERLNDs. In the model, water is exported from residential areas with private-water supplies and public sewers (code 2), and imported to residential areas with publicwater supplies and private sewers (code 3 ). There is assumed to be no net transfer of water in residential areas with the other two infrastructure combinations (codes 1 and 4).

\section{Hydrologic Response Units}

Fifty-six unique HRUs were created by combining the simplified surficial-geology, land-use, and public water and public sewer system data layers. These combinations were grouped further on the basis of size (areas less than about 0.3 percent of the total basin area were grouped into HRUs with the most similar characteristics) and hydrologic importance. For example, in areas classified as commercial-industrial-transportation that likely have disturbed near-surface soils and may contain fill, surficial geology was deemed to be relatively unimportant; thus, all areas classified as commercial-industrial-transportation land use were combined to form a single HRU. Similar reasoning was used to group the water-sewer categories for various HRUs. Combining HRUs 
in this manner yielded a more-manageable 17 PERLNDs and 2 IMPLNDs (fig. 11). Following the approach used by Zarriello and Ries (2000) to simulate flows in the Ipswich River Basin in northeastern Massachusetts, wetlands and open water were treated as storage components rather than PERLNDs. Consequently, they were simulated as "virtual" RCHRESs, as described below. A general description of the 17 PERLND and 2 IMPLND types used in the Blackstone River Basin HSPF model and their total areas in the basin are given in table 9. The areas of wetlands and open water also are given in table 9. The area of each HRU in each subbasin was determined by intersecting the HRU data layer with the subbasin (reach) delineations.

Two identical sets of HRUs were defined in the UCI file: one set (PERLNDs 1 through 17 and IMPLNDs 30 and 31) was defined for the HRUs in the northern part of the basin that use data from the Worcester, Mass. climatological station, and a second set with numbers increased by a factor of 100 (PERLNDs 101 through 117 and IMPLNDs 130 and 131) was defined for HRUs in the southern part of the basin that use data from the Warwick, R.I. climatological station. A single parameter value was used for like HRUs (for example, PERLNDs 1 and 101) in each set. PERLND numbers 1

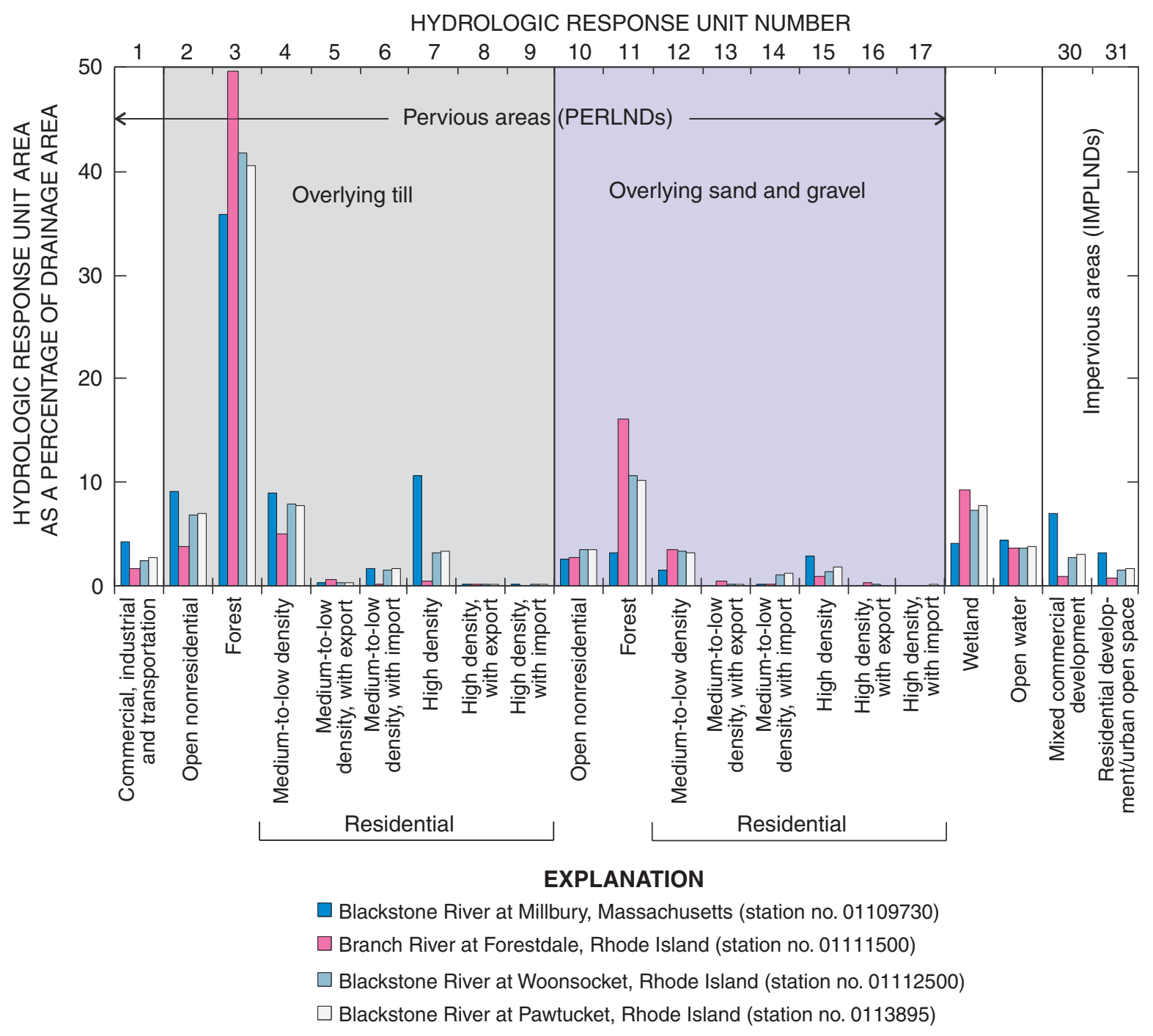

Figure 11. Areas of hydrologic response units (HRUs), wetlands, and open water as percentages of drainage area. 


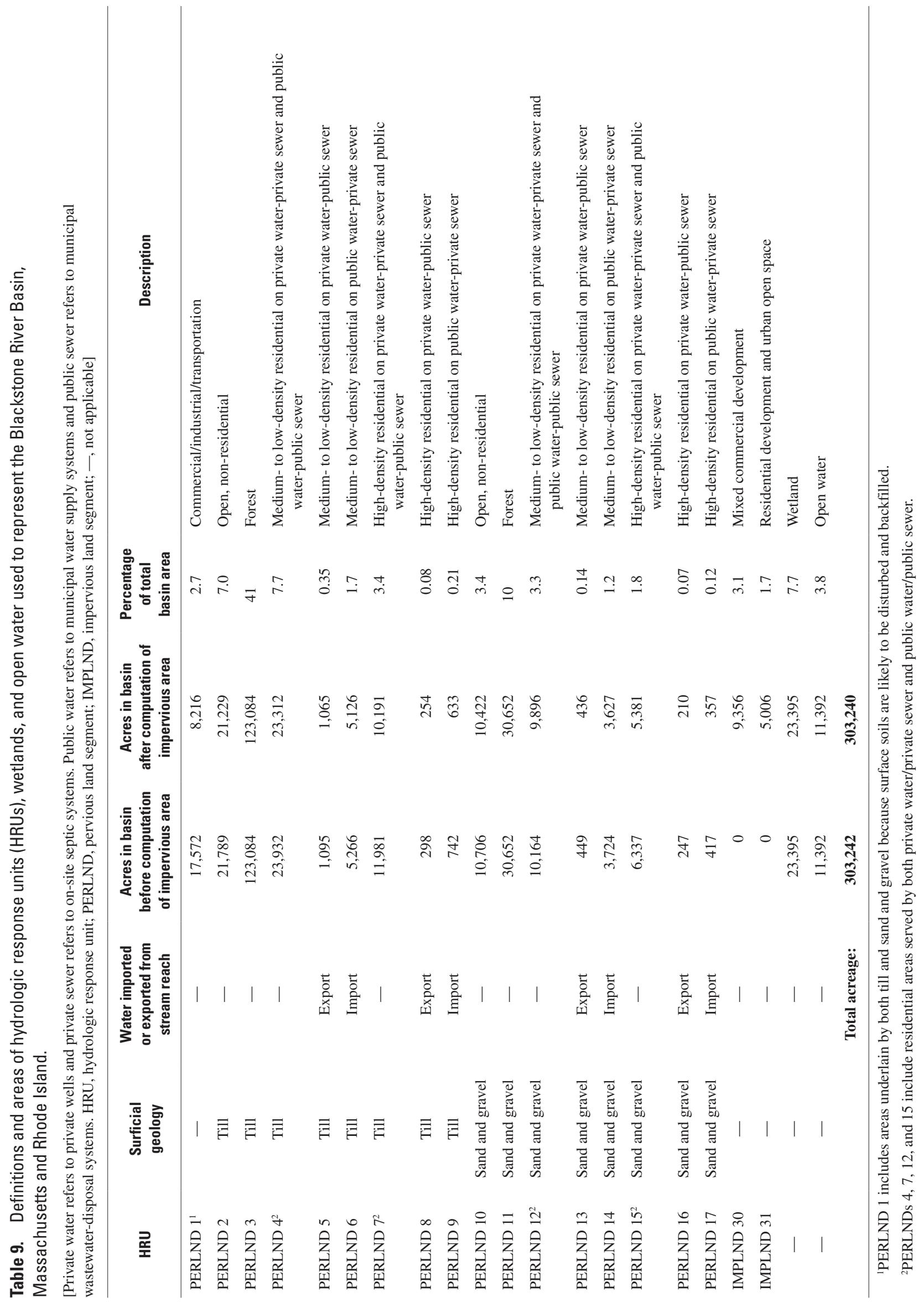


through 17 and IMPLND numbers 30 and 31 are used hereafter to represent both sets of HRUs.

\section{Impervious Areas (IMPLNDs)}

Impervious areas that drain directly to streams (hydrologically effective impervious areas) are simulated in HSPF as IMPLNDs. Impervious areas that drain to pervious areas (hydrologically ineffective impervious areas) are incorporated into the PERLNDs. Initial estimates of effective impervious area were determined as a percentage of the areas of the developed land-use classes in the composite land-use data layer consisting of 20 LULC categories created from the original state data layers to preserve the information content of these categories. The groupings used to compute the effective impervious areas differed slightly from the groupings used to define the land-use categories in the model.

The initial percentages of impervious area for various developed land-use types were obtained from similar land-use types reported by Alley and Veenhuis (1983) (data not shown). The final percentages used to compute effective impervious area were obtained primarily by visual inspection of the overall responsiveness of the hydrograph to precipitation in the developed parts of the basin, and also by calibration of small summer storms that are considered to generate runoff mostly from effective impervious surfaces (table 10) (Zar- riello and Ries, 2000). Two IMPLND types were used in the model: mixed commercial development (IMPLND 30) and residential development and urban open space (IMPLND 31). Hydrologically, these two IMPLNDs are similar, but they were given unique HRUs for possible future water-quality applications. About 31 percent of the basin is classified as developed, but the effective impervious area was estimated to be about 5 percent of the basin area (table 9). The estimated total effective impervious area as a percentage of basin area ranged from about 10 percent in the relatively developed drainage areas to about 2 percent in the undeveloped areas. For example, the total effective impervious area as a percentage of the total drainage area is 10.1 percent in the drainage area to the Blackstone River at Millbury, Mass. streamflow-gaging station (station no. 01109730), 9.3 percent in drainage area to the Quinsigamond River at North Grafton, Mass. station (station no. 01110000), 1.7 percent in the drainage area to the Branch River at Forestdale, R.I. station (station no. 01111500), and 4.3 percent in drainage area to the Blackstone River at Woonsocket, R.I. station (station no. 01112500).

\section{Pervious Areas (PERLNDs)}

Pervious surfaces that allow infiltration and impervious areas that drain to pervious areas are represented in HSPF as PERLNDs. Forests are the dominant PERLND type throughout the watershed (table 9); commercial and residential land

Table 10. Effective impervious area by developed land-use type for the Hydrological Simulation Program-FORTRAN (HSPF) model of the Blackstone River Basin, Massachusetts and Rhode Island.

$[<$, less than; $>$, greater than $]$

\begin{tabular}{|c|c|c|c|}
\hline Land-use classification & $\begin{array}{l}\text { Area in } \\
\text { basin } \\
\text { (acres) }\end{array}$ & $\begin{array}{l}\text { Percentage of area } \\
\text { that is effective } \\
\text { impervious }\end{array}$ & $\begin{array}{l}\text { Effective } \\
\text { impervious area } \\
\text { (acres) }\end{array}$ \\
\hline $\begin{array}{l}\text { Commercial development: } \\
\text { Sales and service facilities } \\
\text { Industrial manufacturing, design, and assembly facilities } \\
\text { Transportation }\end{array}$ & 14,619 & 64 & 9,356 \\
\hline High-density residential development $(<1 / 8$-acre lots) & 4,819 & 18 & 867 \\
\hline Medium-high density residential development (1/4- to $1 / 8$-acre lots) & 15,203 & 14 & 2,128 \\
\hline $\begin{array}{l}\text { Medium-density development: } \\
\text { Medium-density residential (1- to } 1 / 4 \text {-acre lots) } \\
\text { Water and wastewater-treatment facilities, active landfills, and junkyards } \\
\text { Developed recreational }\end{array}$ & 26,874 & 5 & 1,344 \\
\hline $\begin{array}{l}\text { Low-density development: } \\
\text { Low-density residential (> 1-acre lots) } \\
\text { Urban open space }\end{array}$ & 33,360 & 2 & 667 \\
\hline Total: & 94,876 & & 14,363 \\
\hline
\end{tabular}


uses are more extensive in the developed north and southeastern parts of the basin (fig. 2).

Pervious areas in the basin are represented by eight PERLNDs overlying till, eight PERLNDs overlying sand and gravel, and one PERLND overlying both surficial-geology types combined (table 9). Two HRUs represent open, non-residential space (PERLND 2 overlying till and PERLND 10 overlying sand and gravel), two HRUs represent forested areas (PERLND 3 overlying till; PERLND 11 overlying sand and gravel), six HRUs represent medium- to low-density development with different water-supply and wastewater-disposal combinations (PERLNDs 4, 5, and 6 overlying till and PERLNDs 12,13, and 14 overlying sand and gravel), and the remaining six HRUs represent high-density development with the same water-supply and wastewater-disposal combinations as for medium- to low-density development (PERLNDs 7, 8, and 9 overlying till; PERLNDs 15,16, and 17 overlying sand and gravel). The residential HRUs are discussed in greater detail below. Areas classified as commercial-industrial-transportation overlying both till and sand and gravel were combined to form a single HRU (PERLND 1).

Open, non-residential land composes about 10.4 percent of the watershed, with 7.0 percent in areas underlain by till (PERLND 2) and 3.4 percent in areas underlain by sand and gravel (PERLND 10). Because this category combines a mixture of different land-uses (developed recreational spaces, urban open spaces, cemeteries, orchards and nurseries, and other agricultural lands such as hay fields and cropland), both developed and undeveloped areas are represented by these HRUs. The developed areas contain both effective and ineffective impervious surfaces, while the undeveloped areas do not. Consequently, about 40 percent of the total initial area of these HRUs (developed recreational space and urban open space) was treated as developed land and used in the calculation of effective impervious area. Calibrated evapotranspiration, infiltration, soil-water storage parameter values were similar to values for medium- to low-density residential HRUs for similar types of surficial geology (appendix 1).

Forest overlying till (PERLND 3), which represents about 41 percent of the total area in the basin, is the dominant HRU in the watershed followed by forest overlying sand and gravel (PERLND 11), which represents about 10 percent of the total area (table 9). Forests compose up to 75 percent of the area in subbasins in the relatively undeveloped western part of the basin and as little as 13 percent in subbasins in urban areas. Forests compose 39 percent of the drainage area to the Blackstone River at Millbury, Mass. streamflow-gaging station (station no. 01109730), 66 percent of the drainage area to the Branch River at Forestdale, R.I. station (station no. 01111500), and 52 percent of the drainage area to the Blackstone River at Woonsocket, R.I. station (station no. 01112500).

Residential areas of similar density were divided into three HRUs for each type of surficial geology to account for differences in the water and sewer infrastructure serving these areas. Residential areas on public water and on-site septic systems were considered to produce a net inflow (or import) of water to the area-PERLNDs 6 (till) and 14 (sand and gravel) represent medium- to low-density residential areas, and PERLNDs 9 (till) and 17 (sand and gravel) represent high-density residential areas. Residential areas on private wells and public sewer systems were considered to produce a net outflow (or export) of water from the area-PERLNDs 5 (till) and 13 (sand and gravel) represent medium- to low-density residential areas, and PERLNDs 8 (till) and 16 (sand and gravel) represent high-density residential areas. The water imported to or exported from these residential areas is not linked to any specific source or treatment facility. Thus, the location of the public water-supply sources or treatment facilities is inconsequential to these transfers.

Residential areas with the other two water supply and disposal combinations, private wells and septic systems and public water and public sewer systems, were considered to produce no net transfer of water from the area. PERLNDs 4 (till) and 12 (sand and gravel) represent medium- to low-density residential areas, and PERLNDs 7 (till) and 15 (sand and gravel) represent high-density residential areas. In areas where water is self-supplied and wastewater is self-disposed, water is cycled (withdrawn and returned) locally. In areas where residences and businesses are connected to both public water and public sewer systems, there is no net import or export of water from the area. Because of the lack of import and export, the model was simplified by combining the residential areas with these water-sewer infrastructure combinations to form PERLNDs 4, 7, 12, and 15 (table 9).

\section{Stream Reaches (RCHRES)}

The Blackstone River and its main tributaries were segmented into 50 reaches (fig. 8; table 11). Segmentation was based on hydrologic characteristics, the availability of streamflow data, and to a lesser extent, the size of the drainage area and water- and land-use characteristics. Fourteen reaches were established along the main stem of the Blackstone River, and 36 reaches were established on the tributaries. Most tributaries were subdivided into multiple reaches. For example, Abbott Run was represented by 3 reaches, the Branch River and its main tributaries by 10 reaches, Kettle Brook and the Mumford River by 4 reaches each, and the Quinsigamond River, Mill River, and West River by 2 reaches each.

The linkage of reaches to one another is specified in the SCHEMATIC block. In most cases, the linkages are obvious (as shown in fig. 8), with a single reach flowing into the adjacent downstream reach. Where the confluence does not coincide with a reach junction (node), the linkages between some tributaries and the main stem are less obvious. An example is reach 37 on the lower Branch River, which together with reach 31 , flows into reach 30 . Other locations where multiple reaches are linked are shown in table 11.

\section{Hydraulic Characteristics (FTABLEs)}

Stage-storage-discharge characteristics (FTABLEs) were developed for the outflow gate used to route water from each of 
the 50 reaches. These characteristics are usually defined by the hydraulic properties at the downstream end of the reach, but the discharge-volume relation is a function of the properties of the entire reach. FTABLEs were developed to represent lake or reservoir (hereafter referred to as reservoir FTABLEs) depthstorage-discharge relations in the 14 reaches dominated by large surface-water bodies (table 11). FTABLEs representing stream reaches were developed for the remaining 36 reaches.

For most of the stream reaches in the model, the channelgeometry analysis program (CGAP) by Regan and Schaffranek (1985) was used to define the relations among depth, surface area, and volume. A supplemental program, GENFTBL, reads the channel-geometry output from CGAP to calculate the stage-storage-discharge relation by solving Manning's equation for open-channel flow. CGAP requires cross-sectional channel geometry, which was obtained from discharge-measurement notes at each of the streamflow-gaging stations in the basin and from field data collected for Federal Emergency Management Agency (FEMA) flood-insurance reports. For reaches in which channel-geometry measurements were not available, measurements from nearby streams with similar hydraulic characteristics were used in the CGAP and GENFTBL programs or channel-geometry and flood plain information from topographic maps of the area was used in the program XSECT (AquaTerra Consultants, 1998, written commun.) to develop FTABLEs. XSECT differs from CGAP in that the channel cross section is assumed to be trapezoidal. Both GENFTBL and XSECT require Manning's roughness coefficients to calculate flow velocity; these coefficients were estimated from guidelines by Coon (1998) and Arcement and Schneider (1989). In reaches with streamflow-gaging stations, calculated stage-discharge relations were compared with measured discharges, and the stage-storage-discharge relations in the FTABLE were adjusted, if necessary, to improve the representation of the hydraulic characteristics of the reach.

Stream lengths and slopes were determined from geospatial data describing stream centerlines and altitudes. The numerous dams in the basin have a substantial effect on the hydraulic characteristics of the stream reaches; where dams are prevalent, the elevation difference in a reach is represented by a series of flat-water impoundments separated by abrupt hydraulic drops. Because altitude drops at dams do not contribute to the energy slope of a reach, the total hydraulic height of the dams in a reach was subtracted when calculating the slope. As an example of the effect of dams on slope, the altitude of the main stem of the Blackstone River (represented by reaches BL1A-BL13), drops from $402 \mathrm{ft}$ to $20 \mathrm{ft}$, for a total $382 \mathrm{ft}$, and there are 16 dams in these reaches with a total hydraulic drop of $207 \mathrm{ft}$, or 54 percent of the total elevation drop.

For reservoirs, various methods were used to define the stage-storage-discharge relations. Reservoir capacity data were available for 7 of 14 reservoirs simulated in the model. For the remaining reservoirs, stage-storage relations were estimated by use of bathymetry data (Massachusetts Department of Fisheries and Wildlife, 2004) or the topography of the stream valley near the reservoir along with the dam height. Similar bathymetry data were not available for Rhode Island water bodies. Most of the storage volume of a reservoir does not play a role in precipitation-runoff relations under normal climatic conditions; however, to allow for possible future use of the model for water-quality simulations, when reservoir volumes may be more relevant, the full storage volumes of the reservoirs were included in most of the FTABLEs.

On the basis of visual inspection and other documentation, reservoir outlet structures included spillways of various designs equipped with flashboards, weirs, or low-level gates. The stage-storage-discharge relations were developed to represent the observed outlet structure as realistically as possible. Data on the size, shape, and altitude of the outlet structures were used where available; otherwise, approximations based on visual inspection were made to develop the FTABLEs. Weir rating curves were available for Lynde Brook and Kettle Brook No. 1 reservoirs (reach 11) and Holden Reservoir No. 2 (reach 5). For all other reservoirs, flow was calculated with a broad-crested weir-flow equation (Crowe and others, 2001) or an orifice-flow equation (Fread, 1993). Reservoir management activities, such as adding or removing flashboards or changing gate settings, were not considered for the base calibration.

\section{Wetlands}

Wetlands and open water, which account for 11.5 percent of the basin area, represent an important storage component of the watershed. To account for this storage, wetlands and open water were combined and simulated as "virtual" reaches. Representing wetlands as reaches that exchange water with the atmosphere through precipitation and evapotranspiration and receive inflows from adjacent PERLNDs and IMPLNDs, rather than as PERLNDs where evapotranspiration losses are limited to precipitation falling directly on the wetlands, was found to be an effective means of simulating wetlands in the Ipswich River Basin in Massachusetts (Zarriello and Ries, 2000). The amount of evapotranspiration loss in wetlands is typically much larger than the direct precipitation on the wetlands because additional water is available from surface and subsurface flows from surrounding uplands. When wetlands are simulated as PERLNDs, evapotranspiration loss is limited to the difference between precipitation falling directly on the wetland and runoff from the wetland, which can result in oversimulation of observed flows. All PERLNDS and IMPLNDS were assumed to drain into the virtual reaches before draining into the stream and reservoir reaches.

Virtual reaches were developed for all subbasins. They represent the combined storage of all wetlands and open water in the reach. To account for the area of wetlands and open water in a reach, the surface area in the virtual reaches was set equal to the combined area of wetlands and open water. This resulted in an accurate total surface area for each subbasin. However, surface areas were decreased at the lowest flows (below approximately $1.0 \mathrm{ft}^{3} / \mathrm{s}$ ) to account for decreases in free-water surface in wetlands and open water during dry periods and prevent excessive evapotranspiration loss during these periods. To compensate for the presence of the virtual reaches, precipitation and evapotranspiration were not simulated on the regular channel 


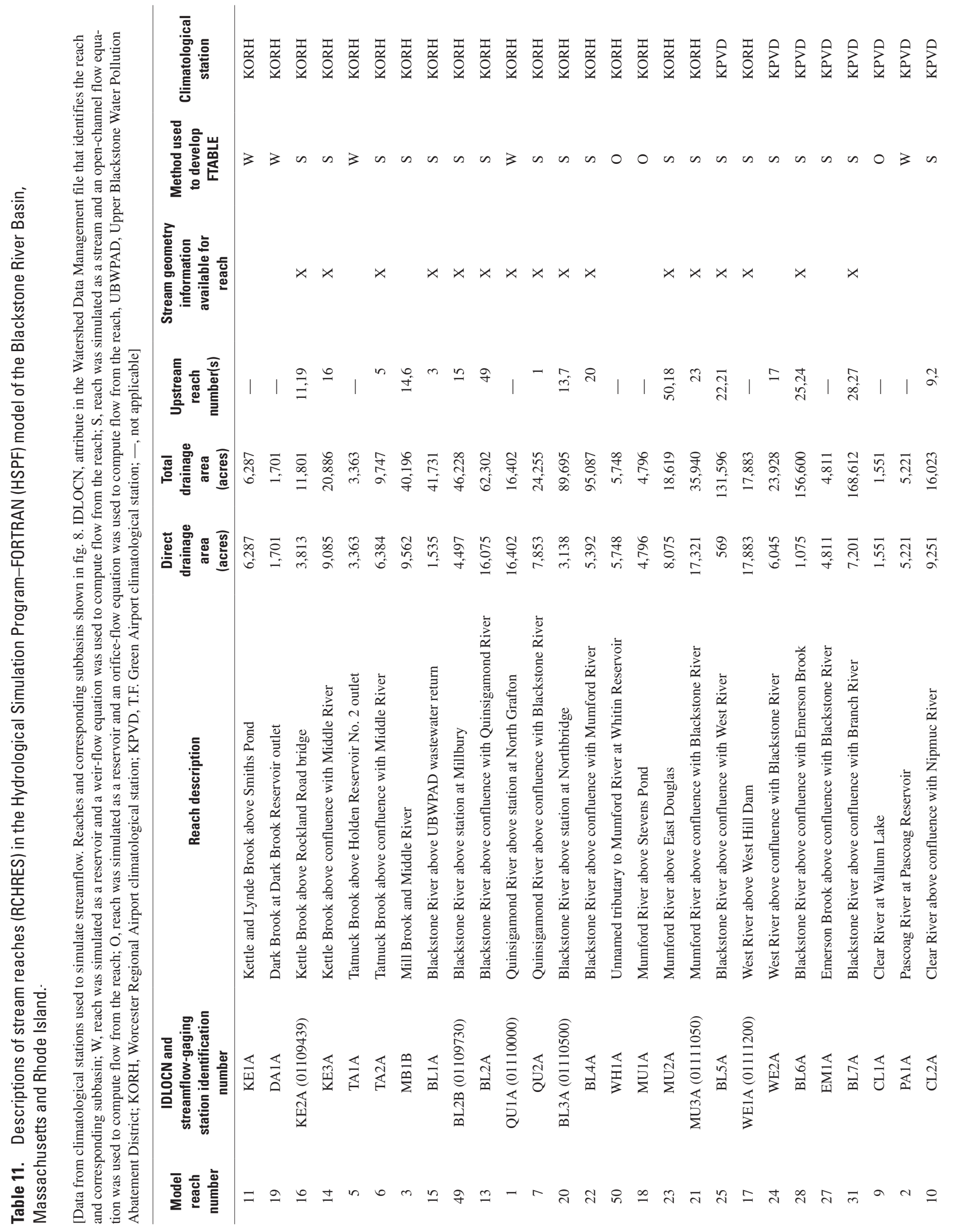




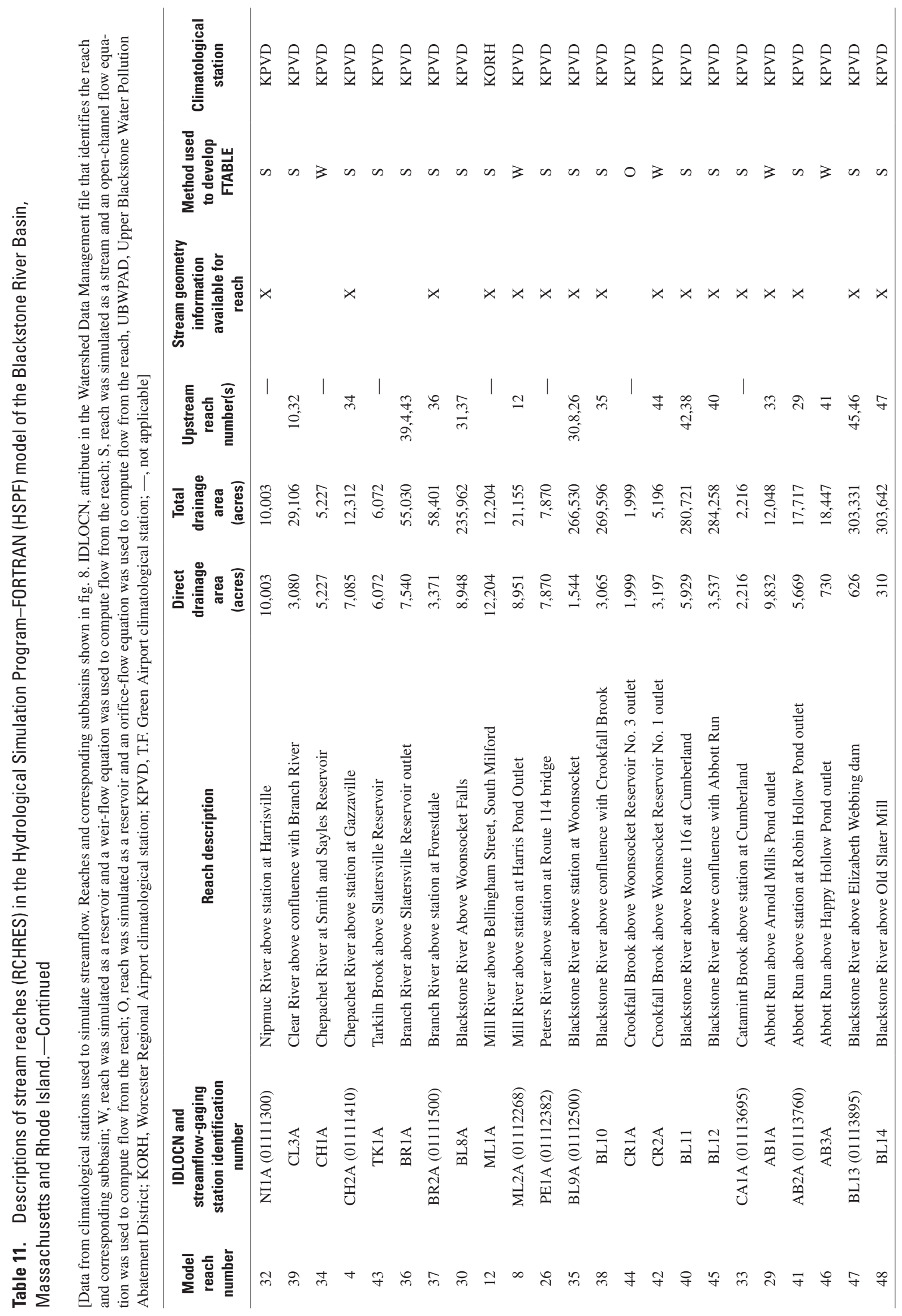


and reservoir reaches because this would have added surface area, and corresponding atmospheric exchanges, to the model.

Storage-discharge characteristics for the virtual reaches were similar to those developed by Zarriello and Ries (2000) for the Ipswich River Basin. Further empirical adjustments were made to about 20 virtual-reach FTABLEs by matching the simulated and observed hydrographs. Simulating wetlands as reaches yielded good agreement between simulated and observed hydrographs; however, the storage-discharge characteristics and interactions between ground water and surface water are not well defined for virtual reaches. Also, simulating wetlands as reaches with a variable area introduces a structural error in the model, because the drainage area that exchanges water with the atmosphere decreases during dry periods (Zarriello and Ries, 2000). Future investigations that involve HSPF simulation would benefit from measuring ground-water levels in wetlands so that the wetlands module in HSPF (version 12) could be used to simulate the hydrology of wetlands in a less empirical manner.

Approximately one-third of the virtual-reach FTABLEs were adjusted empirically during calibration. These changes typically involved changing the functional relation between storage and discharge (that is, the rate of change of discharge for a given change in storage) for specific flow ranges to improve the model fit.

\section{Water Use}

Certain aspects of the complex water use in the basin were simplified for inclusion in the HSPF model. For example, in most cases, transfers of water across the basin boundary and between towns and water suppliers in the basin are not explicitly represented in the model. Rather, all major water-supply withdrawals from ground-water and surface-water sources that are distributed through public water systems and the wastewater-return flows through municipal wastewater-treatment plants are represented in the model as individual withdrawal and return time series in the individual reaches (or subbasins) where they are located; the difference between total withdrawals and total return flows represents the net overall import or export of water for the basin. The model does not explicitly simulate leakage (unaccounted for water) from municipal water-supply systems, which is estimated to be 10 to 15 percent of the water withdrawn for municipal water supply (Barlow, 2003); however, most of this water is likely accounted for in the HSPF model by the difference between reported water-supply withdrawals and wastewater-return flows. Withdrawals from minor suppliers (such as housing developments, apartment complexes, and nursing homes), private wells that are returned locally to on-site septic systems (that is, supplies not connected to a distribution system), and permitted wells with reported withdrawals below about $1 \mathrm{Mgal} / \mathrm{yr}(0.0027 \mathrm{Mgal} / \mathrm{d})$ also were not included in the model. Further simplifications include omitting agricultural withdrawals, with the exception of golf-course withdrawals, and consumptive losses associated with residential withdrawals and minor public suppliers. Agricultural water use was omitted because total agricultural water use is less than 1 percent of the total water use in the basin, and withdrawals are widely dispersed as numerous small withdrawals throughout the basin. An analysis of 1997 county-level farm statistics indicates that total agricultural water use from irrigation of crops and nursery plants and livestock consumption averages about $0.44 \mathrm{Mgal} / \mathrm{d}$ for the entire basin, or about $0.0013 \mathrm{Mgal} / \mathrm{d}$ per square mile in Rhode Island and $0.00078 \mathrm{Mgal} / \mathrm{d}$ per square mile in Massachusetts (U.S. Department of Agriculture, 1999a,b).

Thirty-six of the reaches in the model contain municipal and commercial/industrial withdrawals, and 20 reaches contain municipal and commercial/industrial wastewater-return flows (fig. 9). Thirty-five reaches contain withdrawals from residential areas with private wells and public sewers (fig. 9). Septic-effluent returns are associated with specific HRUs and thus are distributed throughout the basin. Withdrawals, returns, and transfers are specified in the EXTERNAL SOURCES block of the UCI file.

In HSPF, outflows from different exits must be satisfied in successive order. For example, the time-dependent volumeoutflow demands for municipal and commercial/industrial withdrawals (exit 1) must be satisfied before water is routed downstream (exit 2). In reaches where there are only municipal and commercial/industrial withdrawals ( 9 of 50 reaches) or residential withdrawals ( 8 of 50 reaches), the withdrawals are taken from the first exit and the remaining flow is routed downstream through the second exit. In reaches where there are both municipal and commercial/industrial withdrawals and residential withdrawals ( 27 of 50 reaches), the withdrawals are taken from the first and second exits, respectively, and the remaining flow is routed downstream through the third exit. The first outflow exit is used to route water downstream in reaches where no withdrawals occur (6 of 50 reaches). In reach 14 (lower Kettle Brook), a fourth exit is specified to direct flow through a flood-control structure (Kettle Brook diversion tunnel) that links Kettle Brook to the Blackstone River in reach 49.

Municipal and Commercial/Industrial Withdrawals. Time series for each of the 129 municipal and commercial/ industrial withdrawals in the basin were grouped by reach. When a reach contained multiple withdrawals (table 5), they were summed to obtain a total streamflow-depletion rate (demand) for that reach and stored in DSNs 101 to 150 (table 3), corresponding to reaches 1 through 50 respectively. These demands were routed through the first outflow exit (OVOL 1) from the reach (fig. 7).

The water-supply systems for Worcester, Mass., Woonsocket, R.I., and Pawtucket, R.I. are large and generally consist of multiple surface-water sources with intrabasin transfers of surface water. The Worcester and Woonsocket systems consist of multiple surface-water sources, and the Pawtucket system consists of both surface-water and groundwater sources. The representations of these relatively complex systems in the HSPF model are described below.

The water-supply system for the city of Worcester and surrounding communities is composed of seven surfacewater reservoirs in the Blackstone River basin (fig. 12), and an additional three reservoirs in the Nashua River Basin. The reservoirs are in the towns of Holden, Leicester, and Paxton, 
Mass. Worcester also has access to, but rarely uses, the Wachusett Reservoir, Quabbin Aqueduct Shaft 3, and ground-water sources for emergency supply. All the active reservoirs in the system feed Holden Reservoir No. 1, where water is withdrawn to the adjacent filtration plant for distribution. Water flows by gravity through the Kettle Brook reservoir system to Lynde Brook Reservoir, and then is piped to Holden Reservoir No. 1. Flows through the Kettle Brook system are controlled by gates, but the gate settings and associated flow rates are not available. The flow from Lynde Brook to Holden Reservoir No. 1 is metered (table 5; DSN 2113). Holden Reservoir No. 1 also receives metered flow from Kendall Reservoir in the Nashua River Basin and Holden Reservoir No. 2, which is on Tatnuck Brook immediately downstream from Holden Reservoir No. 1. Spills from Kettle Brook No. 1, Lynde Brook, and Holden No. 2 reservoirs are lost from the water-supply system.

To represent this system in the HSPF model, the four Kettle Brook reservoirs and the Lynde Brook Reservoir were enclosed within a single subbasin (KE1A, reach 11) so that the individual flows between the reservoirs did not need to be explicitly defined, and the storage volumes could be combined in the reach FTABLE (fig. 8). Similarly, Holden Reservoirs No. 1 and 2 were enclosed within reach 5 so that the transfer of water from Reservoir No. 2 to Reservoir No. 1 could be omitted and their storages combined. The water diverted from Lynde Brook Reservoir to Holden Reservoir No. 1 was represented as a withdrawal from reach 11 (table 5; DSN 2113) and a return flow to reach 5 (table 5; DSN 2113) in the EXTERNAL SOURCES block of the UCI file. The transfer of water from Kendall Reservoir also was represented as a return flow to reach 5 (DSN 405). The removal of water from Holden Reservoir No. 1 to the filtration plant was represented as a withdrawal from reach 5 (DSN 2050). Thus, reach 5 receives water from two external sources and loses water to one external output demand.

During calibration, it was determined that the output demand from reach 5 was not being satisfied by the two external sources of water plus runoff from precipitation on the subbasin. The deficit was mainly during the winter months. To provide sufficient water to meet the demand, a time series of supplemental water (DSN 1009) was developed by calculating the deficit between the sum of the inputs from the Lynde Brook and Kendall Reservoirs and the withdrawal to the filtration plant for each day of the calibration period, and then reducing the deficit by a smoothed time series of simulated runoff from the reach under unstressed conditions. The daily time series of simulated runoff under unstressed conditions was smoothed by use of a 90-day moving average to reduce the effect of short-term variability in runoff on the time series of supplemental water. The resulting time series of supplemental water (DSN 1009) was added to reach 5 as an additional return flow. For 1997-2001, the average supplemental flow needed to satisfy the demand was $4.4 \mathrm{Mgal} / \mathrm{d}$, which is 19 percent of the average flow rate of $23.3 \mathrm{Mgal} / \mathrm{d}$ to the filtration plant. Considering the reported flows from Kendall Reservoir (9.3 Mgal/d) and the supplemental flow (4.4 Mgal/d), an average of $13.7 \mathrm{Mgal} / \mathrm{d}$ was imported from the Nashua River Basin for these simulations. Walker and Krejmas (1986) stated that 45 percent of the Worcester water supply was obtained from the Nashua River Basin, but cited no source for this information. They reported $11 \mathrm{Mgal} / \mathrm{d}$ diverted from the Nashua River Basin in 1978 when total water-supply withdrawals were $25.0 \mathrm{Mgal} / \mathrm{d}$. The ratio for the current study is 59 percent (13.7 Mgal/d of $23.3 \mathrm{Mgal} / \mathrm{d}$ ), which may indicate that reported diversions from Lynde Brook Reservoir also were low during the winter months and contributed to the imbalance. The reported summer diversions from Lynde Brook Reservoir are near the maximum rate of $6 \mathrm{Mgal} / \mathrm{d}$ (Phillip Guerin, Worcester Sewer Department, oral commun., 2005).

The water-supply system for the city of Woonsocket is composed of three surface-water reservoirs (fig. 12). Two reservoirs, No. 1 and No. 3, are on Crookfall Brook in Smithfield and North Smithfield, R.I. The third reservoir, Harris Pond, is on the Mill River in Blackstone, Mass. Water is withdrawn from Reservoir No. 1 to the adjacent filtration plant for distribution. Harris Pond is used as a supplementary supply, mainly during the dry summer months. Outflow from Harris Pond is transferred to a pump station and then to Reservoir No. 1. A record of these transfers is available (table 5; DSN 2084). Spills from Harris Pond enter the Blackstone River and are lost from the water-supply system. Reservoir No. 3 is in the headwaters of the Crookfall Brook watershed. Outflow from this reservoir is controlled by two low-level gated outlet pipes. Water is released to Crookfall Brook on an as-needed basis to meet water-supply demands in Reservoir No. 1. Gate settings and associated flow rates from Reservoir No. 3 for 1997-2001 were not available. Thus, Reservoir No. 1 receives water from precipitation on its watershed, Harris Pond, and Reservoir No. 3. Spills from Reservoir No. 1 enter the Blackstone River and are lost from the water-supply system. The reported withdrawals from Reservoir No. 1 to the public-water distribution system (DSN 1009) were assumed to represent the combined withdrawals from the entire reservoir system, including unmeasured flows from Reservoir No. 3.

To represent this system in the HSPF model, each of the three reservoirs is contained within a different subbasin (Harris Pond, reach 8; Reservoir No. 1, reach 42; and Reservoir No. 3, reach 44) (fig. 8). Although only a combined withdrawal record was available for Reservoirs No. 1 and No. 3, they were kept separate for possible future simulations of this water-supply system. The transfer of water from Harris Pond to Reservoir No. 1 was represented in the model as a withdrawal from reach 8 (table 5; DSN 2084) and a return flow to reach 42 (table 5; DSN 2084). The removal of water from Reservoir No. 1 was represented as a withdrawal from reach 42 and a withdrawal from reach 44. The total withdrawal was split between the two reaches because it was determined during calibration that the output demand from reach 42 could not be met during the summer when the entire withdrawal was taken from this reach (that is, insufficient water was flowing from Reservoir No. 3 in reach 44 despite repeated adjustments to the FTABLE). Therefore, the percentages of the total withdrawal (DSN 1009) needed to meet the output demand were determined empirically to be 


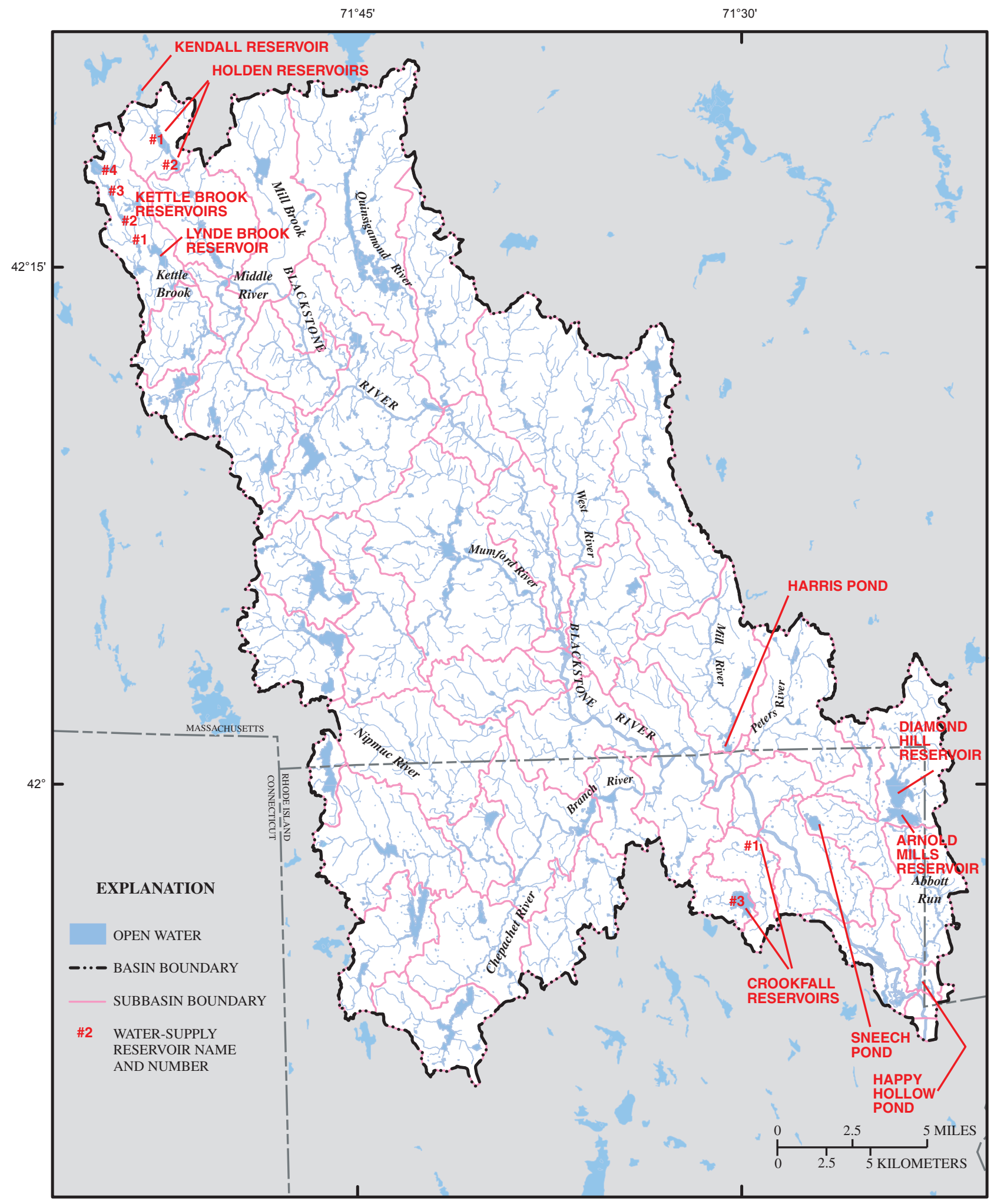

Base from U.S. Geological Survey, 1:24,000, 1995

Massachusetts state plane projection, NAD83

Figure 12. Water-supply reservoirs in the Blackstone River Basin. 
30 percent from reach 42 (table 5; DSN 2420) and 70 percent from reach 44 (table 5; DSN 2440).

The water-supply system for the cities of Pawtucket and Central Falls and part of the Town of Cumberland consists of two surface-water reservoirs (Diamond Hill and Arnold Mills) in the headwaters of Abbott Run, and eight wells along Abbott Run downstream from the reservoirs that are used to supplement the surface-water supply (fig. 12). The intake for the Pawtucket Water Treatment Plant is located at the south end of Happy Hollow Pond, near the confluence of Abbott Run and the Blackstone River (fig. 12). Outflow from the reservoirs is controlled by gates. Flow rates to Abbott Run are regulated on an as-needed basis to meet water-supply demands at Happy Hollow Pond, but gate settings and associated flow rates are not available. To represent this system in the HSPF model, the two reservoirs were enclosed within a single subbasin (AB1A, reach 29) so that the individual flows between the reservoirs did not need to be explicitly defined, and the storage volumes could be combined in the reach FTABLE (fig. 8). The reach of Abbott Run downstream from the reservoirs, which includes ground-water withdrawals, was represented by reach 41, and Happy Hollow Pond, which includes the intake for the watertreatment plant and additional ground-water withdrawals, was represented by reach 46 (fig. 8). The removal of surface water from Happy Hollow Pond was represented by a withdrawal from reach 46 (table 5; DSN 2460), and the removal of ground water was represented by individual withdrawals from reaches 41 and 46 (table 5). Downstream releases of water from the reservoirs were treated as unregulated flows from reach 29 ; the flow rate was controlled by the volume-discharge relation specified in the reach FTABLE. It was not necessary to specify any intrabasin transfers to represent this water-supply system in the model.

Withdrawals in Residential Areas with Public Sewers. Time series for residential withdrawals were estimated from population-density and water-use data. The quantity of water exported from residential areas with private wells and public sewers per reach was calculated by multiplying the population density by an average rate of water use of 71 gallons per day (gal/d) per person (Korzendorfer and Horn, 1995), resulting in export rates of 1,016 gal/d per acre for high-density residential areas, and $265 \mathrm{gal} / \mathrm{d}$ per acre for medium- to low-density residential areas. These export rates were then multiplied by the total area of the appropriate residential density in each subbasin and added together to obtain a total rate of export from the reach. Values were converted to cubic feet per second and read into the model as external withdrawal time series in the EXTERNAL SOURCES block of the UCI file. Total residential withdrawals were routed through the second outflow exit (fig. 7; OVOL 2). Because only 1,965 acres of pervious residential land have private wells and public sewers in the basin (table 9), the quantity of this type of exported water is small; nonetheless, water exported from residential areas was included in the model to represent residential water use in the basin as realistically as possible.
Municipal and Commercial/Industrial WastewaterReturn Flows and Interbasin Transfers. Wastewater is returned to the reach in which the outfall is located as an inflow time series (fig. 7; IVOL) specified in the EXTERNAL SOURCES block. When a reach contained multiple return flows (table 6), they were summed to obtain a total return-flow rate for that reach and stored in DSNs 401 to 450 (table 3), corresponding to reaches 1 through 50 respectively. Interbasin transfers and transfers between subbasins also are represented as inflows to a reach, where necessary.

Wastewater returned to the stream network through treatment-plant outfalls originates from a variety of sources: domestic wastewater from residential and institutional sources, non-domestic wastewater from commercial and industrial sources, storm water from combined sewers, and ground water and storm water from infiltration and inflow (I/I). In the context of a sanitary-sewer system, infiltration refers to ground water that enters the system through leaks in pipes, connections, and manhole walls, and inflow refers to storm water that inadvertently enters the system through interconnections with roof and foundation drains, sump pumps, and manhole covers. Combined sewers (CSs) refer to systems in which storm and sanitary sewers are combined and a portion of the storm runoff is intentionally diverted to the treatment plant. In these systems, combined sewer overflows (CSOs) also may occur during heavy rainfall and snowmelt events. Precipitation on the sewered areas in the basin is the source of I/I and CS return flow. Thus, because wastewater returns are added to reaches as external sources of water in HSPF, I/I and CS contributions to wastewater-return flows represent excess water (that is, water added to the model as both precipitation and wastewater-return flow).

HSPF is not designed to simulate the movement of water in sewer systems in urban areas; however the model has the flexibility to account for the effects of I/I and CS return flow in a simplified manner. To account for infiltration, the parameter DEEPFR was used to represent empirically the flow of ground water into public sewer systems in the basin. DEEPFR is the fraction of infiltrating water lost to deep aquifers, with the remaining fraction assigned to active ground-water storage that contributes base flow to stream reaches. DEEPFR can be used to represent any loss from the ground-water flow system (typically lateral flow from deeper aquifers to adjacent basins or flow under a streamflow-gaging station) that occurs and reduces outflow from ground-water storage (U.S. Environmental Protection Agency, 2000). DEEPFR is one of three mechanisms, along with evapotranspiration and discharge to streams, for removing water from a pervious land segment. In this study, all residential and commercial-industrial-transportation areas that intersect with a public sewer system (table 9; PERLNDs $1,4,5,7,8,12,13,15$, and 16) were assigned non-zero values for DEEPFR to represent infiltration.

Final DEEPFR values of 0.35 for commercial-industrial-transportation areas (PERLND 1), 0.45 for high-density residential areas (PERLNDs 7, 8, 15, and 16), and 0.28 for medium- to low-density residential areas (PERLNDs 4, 5, 
12, and 13) were used to empirically represent the differing sewer-line densities in these land-use categories. Values were adjusted during calibration to obtain a total sewer infiltration loss of about $17 \mathrm{Mgal} / \mathrm{d}$ for the entire basin, which is equal to 34 percent of the total wastewater-return flow of $50.6 \mathrm{Mgal} / \mathrm{d}$ in the basin for 1997-2001. However, roughly 15 percent of the sewered areas in the basin (predominantly the sewered areas in Cumberland and Lincoln, R.I.) discharge to facilities outside the basin, so total wastewater-return flow is closer to $60 \mathrm{Mgal} / \mathrm{d}$ for the basin, and infiltration losses computed with the DEEPFR parameter are closer to 28 percent of the total return flow. DEEPFR losses are stored in the inactive groundwater inflow (IGWI) time series. Although DEEPFR provides only a rough approximation of the spatial and temporal distribution of infiltration losses in the basin, accounting for these losses is more realistic than leaving excess water in the basin, which could skew parameter values.

The sewer system in the Worcester area is the largest (fig. 6) and most complex in the basin and thus required special attention in the model to enable simulation of streamflow from the headwaters of the basin. The total sewered population in the UBWPAD service area was estimated to be 160,900 in 2000 (Camp, Dresser, and McKee, 2001). Return flow from the UBWPAD treatment plant averaged about $35.4 \mathrm{Mgal} / \mathrm{d}$ $\left(55 \mathrm{ft}^{3} / \mathrm{s}\right)$ during the calibration period (table 6$)$, which constituted approximately 20 percent of the summer low flow at the mouth of the basin. A small amount of this flow (about 1.3 Mgal/d) originated from outside the basin in Rutland, Mass.; however, for simplicity this flow was not removed from the total UBWPAD return flow in the analysis that follows. The Regional Wastewater Treatment Facilities Plan, conducted for UBWPAD by Camp, Dresser, and McKee, indicates that the average annual wastewater flow for 1993-1998 was $37.4 \mathrm{Mgal} / \mathrm{d}$, of which $19.6 \mathrm{Mgal} / \mathrm{d}$ was sanitary sewage, $14.0 \mathrm{Mgal} / \mathrm{d}$ was infiltration, and $3.8 \mathrm{Mgal} / \mathrm{d}$ was inflow (Camp, Dresser, and McKee, 2001). The average dry-day wastewater-return flow from UBWPAD for the period was $33.6 \mathrm{Mgal} / \mathrm{d}$. The average inflow rate was calculated as the difference between the total flow and the dry-day flow, and the average infiltration rate was calculated as the difference between the sanitary flow and the dry-day flow. It should be noted that, for this study, measured inflow to UBWPAD was assumed to represent stormwater composed of both the intentional CS return flows and the unintentional stormwater inflows, and is referred to as "inflow plus CS return flow." These calculations indicate that for 1993-98, the total amount of water derived from precipitation on the sewered area (infiltration and inflow plus CS return flow) was about 48 percent of the average wastewater flow to UBWPAD. For 1997-2001, conditions were drier than for 1993-98. Assuming that the lower flows to UBWPAD for 1997-2001 (35.4 Mgal/d) were caused by less infiltration and inflow plus CS return flow (that is, the sanitary-sewage flow rate was unchanged), the total contribution from infiltration and inflow plus CS return flow would be about $15.8 \mathrm{Mgal} / \mathrm{d}$ (35.4 Mgal/d minus 19.6 Mgal/d), of which about $12.4 \mathrm{Mgal} / \mathrm{d}$ was infiltration and the remaining 3.4 Mgal/d was inflow plus CS return flow.

Stormwater from combined sewers that is included in the wastewater flow to UBWPAD was addressed by removing impervious area from the model. The sewer system in the city of Worcester contains approximately 2,500 acres of combined sewers (P. Moosey, Worcester Sewer Department, oral commun., 2005). Wastewater and stormwater flows from the combined-sewer area are directed to the Quinsigamond Avenue CSO treatment facility. Under normal conditions, this facility operates as a pumping station, transferring water to the UBWPAD facility; however, during extremely wet periods when the capacity of the UBWPAD facility has been reached, flow from the combined-sewer area is bypassed to the CSO facility, where it is treated and released to the Blackstone River. A time series of the intermittent releases from the CSO facility during the calibration period is included as an inflow to reach 3 (table 6; DSN 3031). The average flow rate from the CSO facility was $1.1 \mathrm{Mgal} / \mathrm{d}$ for 1997-2001. Because the precipitation that falls on the CS area is accounted for in the CSO and UBWPAD return flows to the model, 1,800 acres of impervious area were removed: 1,200 acres were removed from reach 3, which encompasses most of downtown Worcester, and 600 acres were removed from reach 6 (fig. 8). The CS area removed from the model was reduced from the reported area of 2,500 acres to achieve streamflow reductions consistent with inflows reported in the Regional Wastewater Treatment Facilities Plan (Camp, Dresser, and McKee, 2001) and releases from the CSO plant.

The effect of removing impervious area was determined by computing the average simulated surface-runoff rate from the impervious area for 1997-2001. Removing 1,800 acres of impervious area reduced runoff by $4.9 \mathrm{Mgal} / \mathrm{d}\left(7.6 \mathrm{ft}^{3} / \mathrm{s}\right)$ for 1997-2001. The effect of using the DEEPFR parameter to represent ground-water infiltration to sewers was determined by observing simulated changes in the mean annual flows at the Blackstone River at Millbury, Mass. station. Infiltration losses computed with the DEEPFR parameter reduced the simulated mean annual streamflow by $3.5 \mathrm{Mgal} / \mathrm{d}\left(5.2 \mathrm{ft}^{3} / \mathrm{s}\right)$. Together, these simulated losses of $8.4 \mathrm{Mgal} / \mathrm{d}$ are about 50 percent of the estimated $16.9 \mathrm{Mgal} / \mathrm{d}$ contribution from infiltration and inflow plus CS return flows to UBWPAD (15.8 Mgal/d) and releases from the CSO facility (1.1 Mgal/d) for 1997-2001. The average infiltration loss of $3.5 \mathrm{Mgal} / \mathrm{d}$ computed with the DEEPFR parameter was less than the actual average infiltration loss of $12.4 \mathrm{Mgal} / \mathrm{d}$ for 1997-2001. On the other hand, the average stormwater loss of $4.9 \mathrm{Mgal} / \mathrm{d}$ computed by removing impervious area was in good agreement with the actual average stormwater loss of $4.5 \mathrm{Mgal} / \mathrm{d}$ (3.4 Mgal/d from inflow plus CS return flow to UBWPAD plus $1.1 \mathrm{Mgal} / \mathrm{d}$ from releases from the CSO facility) for 1997-2001. The disparity in infiltration rates is assumed to reflect uncertainty in the reported relative contributions of ground-water infiltration and stormwater runoff to UBWPAD, as well as the use of DEEPFR to represent ground-water infiltration to sewers. 
Septic-Effluent Returns in Residential Areas with Public Water. The quantity of septic effluent imported to residential areas served by public water systems was calculated by multiplying the population density by the average rate of water use of $67 \mathrm{gal} / \mathrm{d}$ per person (Korzendorfer and Horn, 1995), resulting in import rates of $959 \mathrm{gal} / \mathrm{d}$ per acre for high-density residential areas and $251 \mathrm{gal} / \mathrm{d}$ per acre and medium- to low-density residential areas. These import rates were converted to inches per hour per acre $(0.00147 \mathrm{in} / \mathrm{hr} / \mathrm{acre}$ for high-density residential area and $0.000384 \mathrm{in} / \mathrm{hr} / \mathrm{acre}$ for medium- to low-density residential areas), and added to the applicable HRUs (PERLNDs 6, 9, 14, and 17) as inflow to lower-zone storage (LZLI) using an external time series in the EXTERNAL SOURCES block of the UCI file. Applying water to lower-zone storage is appropriate because septic leach fields typically are installed in this part of the soil horizon. In HSPF, water in the lower soil zone is not available to runoff or discharge as interflow or base flow. Rather, this storage zone holds water that is removed to the atmosphere through evapotranspiration. Adding septic effluent to lower-zone storage decreases the storage available in this zone for infiltrating precipitation. Consequently, more infiltrated precipitation reaches active ground-water storage, which is available to discharge as base flow, in areas receiving septic effluent relative to similar areas not receiving effluent.

The estimated import rate from septic systems is $12.9 \mathrm{in} / \mathrm{yr}$ in high-density residential areas and $3.4 \mathrm{in} / \mathrm{yr}$ in medium- to low-density residential areas. These rates represent about 31 and 8 percent of the average annual precipitation of $42 \mathrm{in} / \mathrm{yr}$ on these areas, respectively. Pervious residential areas on public water and private sewers compose about 3 percent $(9,743$ acres) of the basin, of which the majority (8,753 acres) is medium- to low-density development. Thus, the widely distributed septic effluent constitutes a relatively small percentage (about 6 percent) of the total wastewaterreturn flow in the basin. Total return flow of septic effluent averaged 3.1 Mgal $/ \mathrm{d}$ for the entire basin.

\section{Model Calibration}

The Blackstone River Basin model was calibrated for January 1, 1997 to December 31, 2001 using an hourly time step and climatological data from the KORH (Worcester, Mass.) and KPVD (Warwick, R.I.) climatological stations. The precipitation during the calibration period of 1997-2001 was slightly lower than the long-term average precipitation (1960-2004). Precipitation for the calibration period averaged $39.4 \mathrm{in} / \mathrm{yr}$ in the northern part of the basin and $43.1 \mathrm{in} / \mathrm{yr}$ in the southern part of the basin. Of these years, 1998 was the wettest and 2001 was the driest. The 1997-2001 period was used for calibration because land-use data from 1995 (R.I.) and 1999 (Mass.) were used to define the PERLNDs, and considerable water-use data were available from Barlow (2003). Water-use data were available for years more recent than 2001, but because land use is changing rapidly in the basin, a calibration period centered on
1999 (the Mass. data layer represents land use in 71 percent of the basin) was believed to best represent the basin. Initially, 1996 was to be included in the calibration, but it was determined that the reliability of the precipitation records at KORH and KPVD was poor for that year because of changes in data-collection methods. Consequently, the model was run from 1996 onward to allow the initial values for the less-dynamic soil and ground-water storages (upper-zone storage (UZS), lowerzone storage (LZS), active ground-water storage (AGWS), and the initial index to ground-water slope (GWVS) to approach dynamic equilibrium, but 1996 was not used to determine the goodness-of-fit between simulated and observed flows. Wateruse data are needed to calibrate the model parameters. The inclusion of the major stresses in the basin ensures that the net effect of the stresses on simulated hydrographs is represented. Consequently, the calibrated values of the hydrologic parameters better represent the hydrologic response of the basin to precipitation (Zarriello and Ries, 2000).

Simulations for model validation were not conducted because of limited data availability and the intended uses of the model. Water-use information was obtained for 1997-2001 to coincide with the available digital land-use information, and all 5 years of data were used for parameter calibration to represent variability in climatic conditions to the fullest extent possible. Validation would require breaking up the data into shorter periods for calibration and validation, thus reducing the reliability of parameter calibration. The model fit to observed flows during this period provides the best validation of the calibrated model parameters over the widest range of climatic conditions. This approach was deemed appropriate because the model was primarily developed to evaluate relative changes in streamflow that take place in response to predetermined landand water-use conditions in the basin, and to compute flow frequency probabilities for these conditions from long-term climatological data.

The model was calibrated in accordance with guidelines by Donigian and others (1984) and Lumb and others (1994). Calibration entailed first adjusting the parameter values to fit the model output to total and seasonal water budgets, and then adjusting values to improve the model fit for daily flows while maintaining the total and seasonal water budgets. Generally, annual and seasonal flows are affected most by the parameters LZSN (lower-zone nominal storage parameter), LZETP (lower-zone evapotranspiration parameter), DEEPFR (fraction of ground water that enters a deep flow system), UZSN (upper-zone nominal storage parameter), KVARY (ground-water recession parameter that determines the degree of nonlinearity of the recession rate), and AGWRC (active ground-water recession constant). Storm flows are affected most by INFILT (infiltration parameter), INTFW (coefficient that determines the amount of water that enters the ground from surface storage and becomes interflow) and IRC (interflow recession constant). The model was calibrated by first adjusting parameter values as a group for PERLNDs overlying sand and gravel and PERLNDs overlying till. Once reasonable simulation results were obtained, judgments based on hydro- 
logic experience were used to make further adjustments to parameter values for individual PERLNDs representing different land-use types in each of these geologic groups. Parameters representing snow accumulation and melt processes were given less consideration because the primary purpose of the model is to simulate the effects of changes in water demand and land-use on low flows. The snow accumulation and melt routines were included primarily to adjust precipitation data to compensate for inefficiencies in precipitation measurements during cold periods when precipitation was in the form of snow. SNOW section parameters were obtained mostly from other HSPF studies (U. S. Environmental Protection Agency, 2000).

Values for some parameters, such as the slopes and mean altitudes of HRUs, were determined from spatial data. However, most parameters could not be measured directly and were initially assigned values similar to those used for comparable HRUs in the Ipswich River Basin model (Zarriello and Ries, 2000) or values developed from other applications of HSPF across North America (U.S. Environmental Protection Agency, 2000). The iterative process described above then was used to adjust these values to minimize the difference between simulated and observed flows displayed as hydrographs, scatter plots, and flow-duration curves, and reduce the errors in the model-fit statistics. The PERLND parameters that affect the rate of ground-water and interflow recession (AGWRC, KVARY, IRC, and INTFW) and the amount of discharge as base flow and interflow (INFILT, LZSN, UZSN, and LZETP) were adjusted most extensively to calibrate the model. These parameters are discussed in greater detail in the "Sensitivity to Model Parameters" section of the report. Simulation results were insensitive to most of the remaining parameters; consequently, values for these parameters were not adjusted from initial values during the calibration. Parameter values for the calibrated model are given in the partial listing of the UCI file in appendix 1.

Streamflow data from the 15 streamflow-gaging stations in the basin (fig. 4) provided the model-calibration points; however, long-term stations with measured streamflow for the calibration period (Quinsigamond River at North Grafton, Mass. [station no. 01110000]; Branch River at Forestdale, R.I. [station no. 01111500]; Nipmuc River near Harrisville, R.I. [station no. 01111300]; and Blackstone River at Woonsocket, R.I. [station no. 01112500]) provided the primary data for determining calibrated parameter values. In addition to the availability of streamflow measurements during the calibration period, these stations were chosen because the flows are relatively unaffected by regulation, and the drainage areas differ with respect to the amount of development. For example, the drainage area to the Quinsigamond River at North Grafton, Mass. station is relatively developed, whereas the drainage area to the Branch River at Forestdale, R.I. station is dominated by undeveloped, forested land use. Parameter values obtained by fitting the model to data from these four stations best represent the hydrologic response of the basin. Agreement between simulated and observed flows was taken into consideration at the other stations in the basin, but, in general, standards for model performance were relaxed slightly at these stations because observed flows were computed and(or) strongly affected by regulation. Model calibration at these locations was achieved mainly by FTABLE adjustment. It should be noted that all streamflow measurements, whether measured directly during the calibration period or computed by use of record-extension techniques, are referred to as "observed" streamflow in the following discussion of model performance.

The quality of the model fit was examined by mathematical summary statistics provided by utilities in the programs GenScn, HSPEXP, and PEST (Doherty, 2003). The timeseries-compare utility in GenScn provides fit statistics computed from daily and monthly discharge values. The statistics reported here include the simulated and observed mean-flow rates, the mean error, the percent mean error, the root mean square error (RMSE), and the coefficient of determination $\left(r^{2}\right)$ for monthly and daily flows during the calibration period (tables 12 and 13). The mean error is defined as the absolute difference between the mean observed and mean simulated flow rates. The percent mean error is defined as the ratio of the mean error to the mean observed flow rate expressed as a percentage. The RMSE and mean error express the difference between the observed and simulated streamflow in original $\left(\mathrm{ft}^{3} / \mathrm{s}\right)$ units. Tables 12 and 13 show that percent mean errors ranged from -1.6 percent at the Blackstone River at Pawtucket, R.I. station to 16 percent at the Mill River at Woonsocket, R.I. station. Love and Donigian (2002) indicate that HSPF model fits for streamflow are considered very good when errors are less than 10 percent, good when errors are between 10 and 15 percent, and fair when errors are between 15 and 25 percent. The errors in mean monthly and daily flows for the calibration period were within 10 percent at 12 stations, within 10 to 15 percent at 2 stations, and within 15 to 25 percent at 1 station (tables 12 and 13).

The series-compare utility in PEST provided other fit statistics computed from daily mean discharge and total monthly runoff values. These statistics include the NashSutcliffe coefficient $\left(R^{2}\right)$, and the index of agreement (tables 12 and 13). The coefficient of determination, NashSutcliffe coefficient, and index of agreement are common goodness-of-fit measures of the performance of watershed models. All three statistics provide a measure of the amount of the variance in the observed values explained by the simulated values. The Nash-Sutcliffe coefficient and index of agreement, however, provide a more rigorous evaluation of the fit quality than does $r^{2}$ because they are sensitive to differences between the observed and simulated means and variances, whereas $r^{2}$ measures differences between means only and is insensitive to the magnitude of the differences between observed and simulated values (Legates and McCabe, 1999). For example, the widely used Nash-Sutcliffe coefficient, which ranges from minus infinity to 1.0 , is defined as 


$$
R^{2}=1.0-\frac{\sum_{i=1}^{N}\left(O_{i}-S_{i}\right)^{2}}{\sum_{i=1}^{N}\left(O_{i}-\bar{O}\right)^{2}}
$$

Where $S_{i}$ and $O_{i}$ are the model-simulated and observed values, respectively, at time $i, N$ is the number of values for the time period of the evaluation, and $O$ is the observed mean for the entire time period of the evaluation. When $R^{2}$ equals zero, the observed mean is as good a predictor of observed values as the model (that is, the simulated values) (Legates and McCabe, 1999). The Nash-Sutcliffe coefficient for daily mean flows ranged from 0.22 at the West River at Uxbridge, Mass. station to 0.78 at the Blackstone River at Woonsocket, R.I. station (table 13). Results for the index of agreement, which ranges from 0.0 to 1.0 with higher values indicating a better fit, were consistent with results for the Nash-Sutcliffe coefficient, with values ranging from 0.76 at the West River at Uxbridge, Mass. station to 0.94 at the Blackstone River at Woonsocket, R.I. and Pawtucket, R.I. stations (table 13). Overall, the statistics shown in tables 12 and 13 indicate that the agreement between simulated and observed values was poorest at the West River at Uxbridge, Mass. station, possibly due to the regulation of peak flows at the West Hill Dam that is not accounted for in the model. Agreement was best at the Blackstone River at Woonsocket, R.I. and Blackstone River at Pawtucket, R.I. stations.

The HSPEXP program provides model-fit information in terms of the error between various measures of simulated and observed values (table 14). These measures include error during the calibration period in the total and seasonal runoff volumes, flows above the 10th percentile (high flows) and below the 50th percentile (low flows), and the base-flow recession constant, which is the difference in the ratio of the current day's discharge to the previous day's discharge for simulated and observed flows. Errors also are computed for storm-runoff volumes and peak discharges for selected summer storms. These statistics were designed to work with the "expert" advice feature of HSPEXP. In general, errors in the total runoff volumes, low-flow recession constant, high and low flows, and summer storm volumes are within the criteria for acceptable model performance defined by Donigian and others (1984), whereas errors in the storm peaks and seasonal volumes are outside these criteria at most stations (table 14).

Overall, the statistics indicate that the model performs relatively well at the four stations on the Blackstone River and tributaries such as the Mumford River, the Chepachet River, the Peters River, and Abbott Run (tables 12 through 14); however, as discussed in the "Streamflow" section of the report, errors in observed streamflow may be substantial at the stations where streamflow was computed by correlation with surrounding stations. Also, measurement error and flow regulation may result in differences between the measured streamflow record and the natural watershed response at the stations where streamflow measurements were made during the calibration period. Thus, model-fit statistics may reflect the quality of the observed data as well as model performance, particularly at the stations with estimated data. It also should be noted that model-fit statistics reported as a percentage can be a poor indicator of the quality of the fit for low flows because a small absolute difference between the observed and simulated value can appear as a large percentage difference. Visual inspection of the hydrographs, flow-duration curves, and scatter plots of simulated and observed streamflows at varying time scales provide additional information to evaluate model performance.

\section{Annual and Monthly Mean Discharge}

Scatter plots of observed and simulated annual mean discharges for 1997-2001 at selected streamflow-gaging stations are shown in figure 13. Observed annual mean discharges at the stations shown in figure 13 ranged from $30 \mathrm{ft}^{3} / \mathrm{s}$ (Quinsigamond River at North Grafton, Mass., 2001) to $1,020 \mathrm{ft}^{3} / \mathrm{s}$ (Blackstone River at Pawtucket, R.I., 1998). These plots show that the simulated and observed annual mean discharges are generally close to the lines of equality at the three Blackstone River stations (fig. 13B, E, and F), the Branch River at Forestdale, R.I. station (fig. 13D), and the Nipmuc River near Harrisville, R.I. station (fig. 13C). The agreement is not as good at the Quinsigamond River at North Grafton, Mass. station (fig. 13A). Annual mean discharge at the Quinsigamond River at North Grafton, Mass. and Blackstone River at Pawtucket, R.I. stations is oversimulated on average by 6.0 percent and 1.5 percent, respectively, during the calibration period. Annual mean discharge at the Blackstone River at Millbury, Mass., Nipmuc River near Harrisville, R.I., Branch River at Forestdale, R.I., and Blackstone River at Woonsocket, R.I. is undersimulated on average by 2.0 percent, 9.1 percent, 4.7 percent, and 5.0 percent, respectively, during the calibration period. These errors are calculated as the mean of the percent differences for each year in the calibration period. The maximum single-year difference was an oversimulation of 36 percent in 1999 at the Quinsigamond River at North Grafton, Mass. station. The minimum single-year difference was an undersimulation of 0.4 percent in 2000 at the Blackstone River at Woonsocket, R.I. station. Annual mean discharges were most consistently undersimulated during 2001, when undersimulation at all six stations ranged from 19 percent at the Nipmuc River near Harrisville, R.I. station to 4.4 percent at the Blackstone River at Millbury, Mass. station.

Scatter plots of observed and simulated monthly mean discharges for 1997-2001 at selected streamflow-gaging stations are shown in figure 14 . Observed monthly mean discharges at the stations shown in figure 14 ranged from $0.1 \mathrm{ft}^{3} / \mathrm{s}$ (Quinsigamond River at North Grafton, Mass., August 1999) to 2,320 $\mathrm{ft}^{3} / \mathrm{s}$ (Blackstone River at Woonsocket, R.I., March 2001). These plots show that the simulated and observed mean monthly discharges are generally close to the lines of equality over much of the observed range of flows, including months with the lowest flows. Correlation coefficients ranged from 0.91 (Nipmuc River near Harrisville, R.I. 

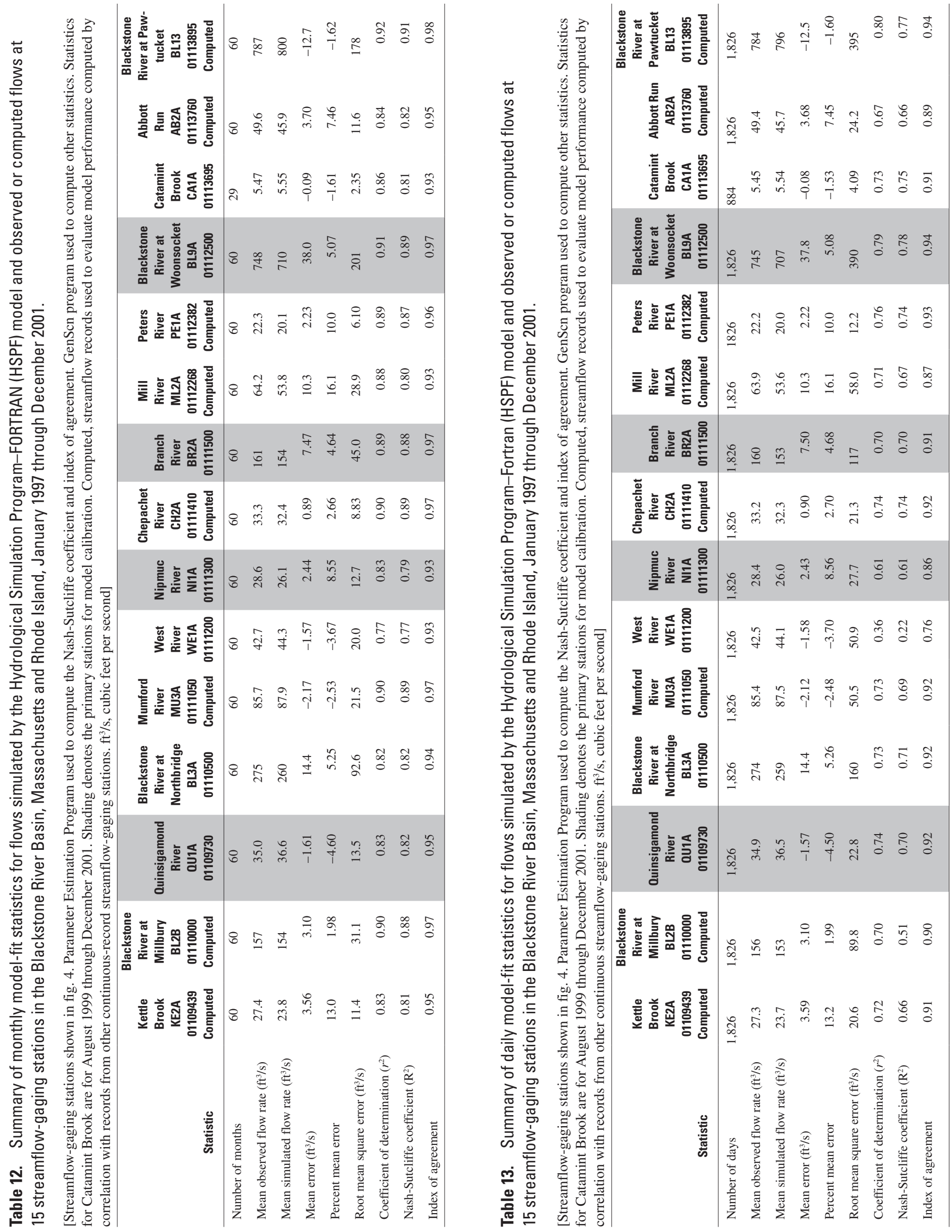


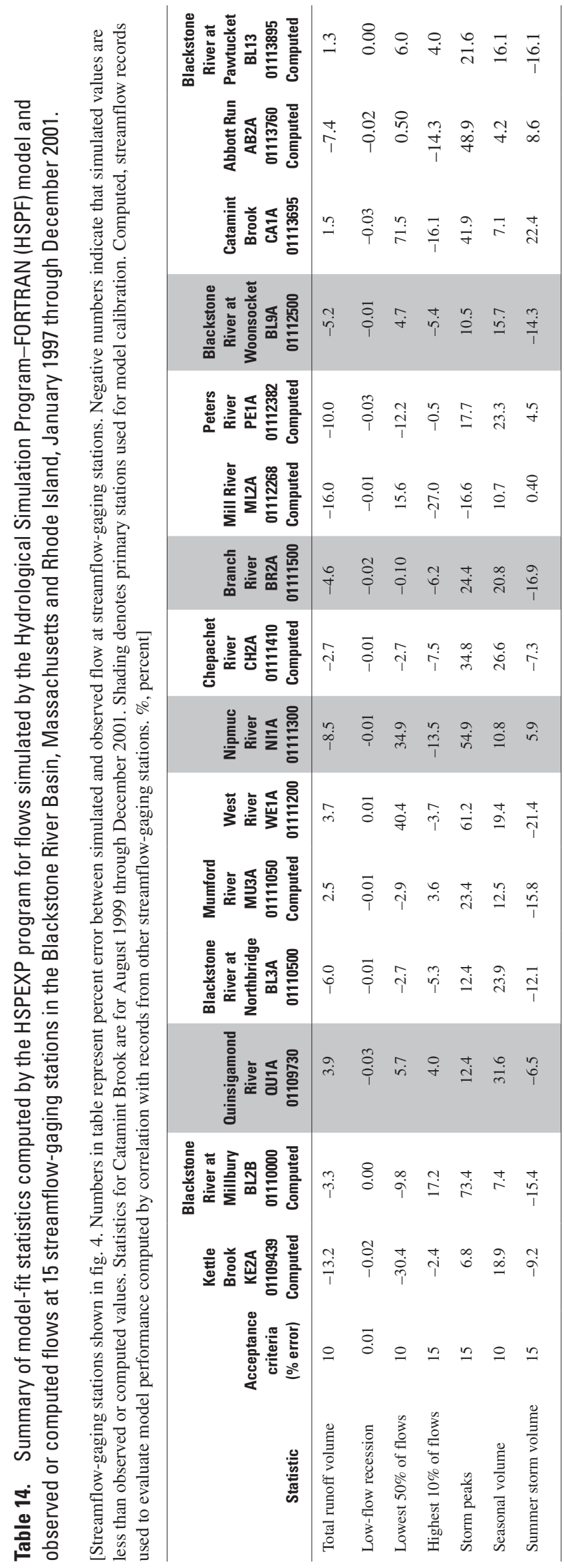




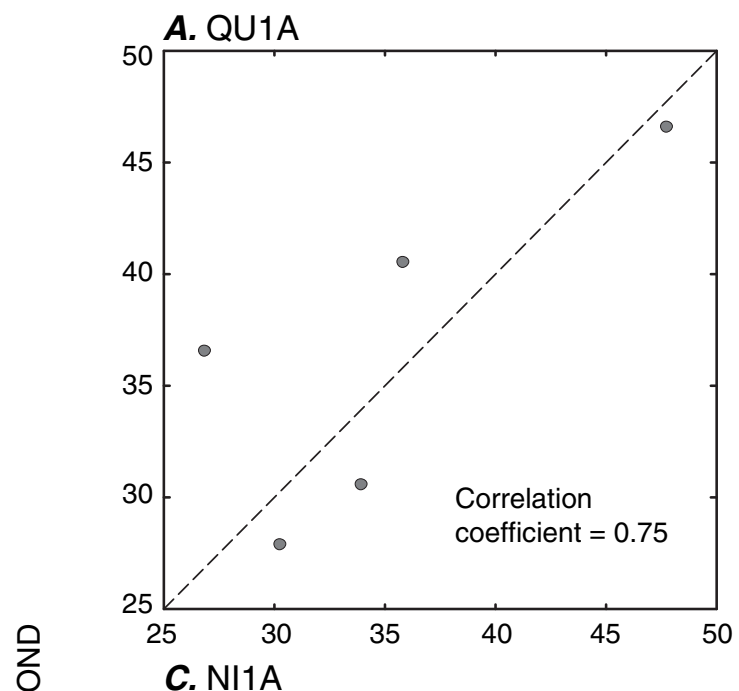

B. BL2B

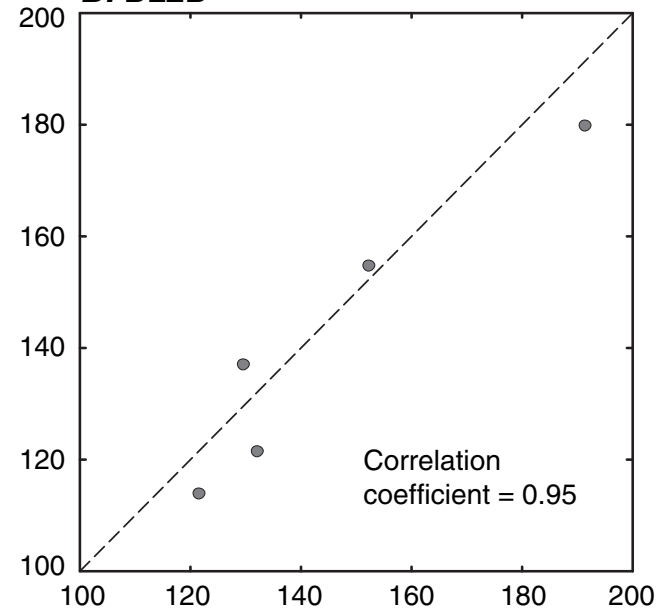

D. BR2A
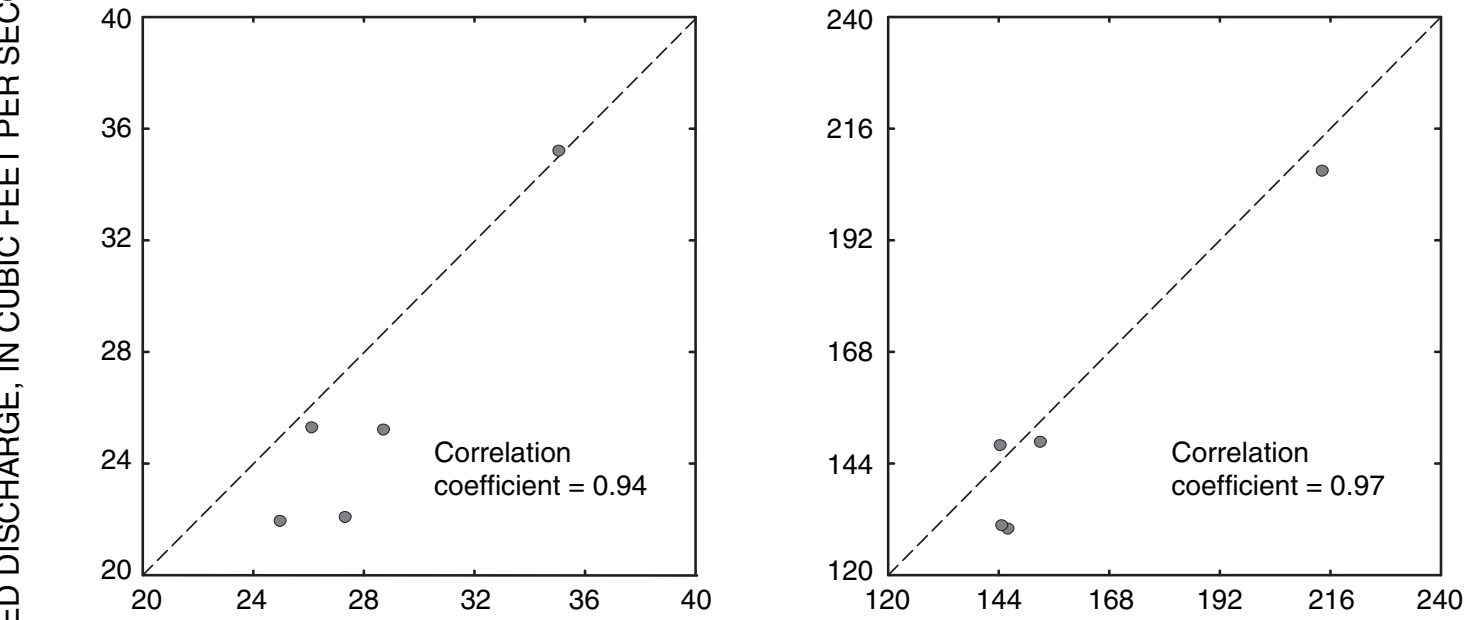

E. BL9A

F. BL13

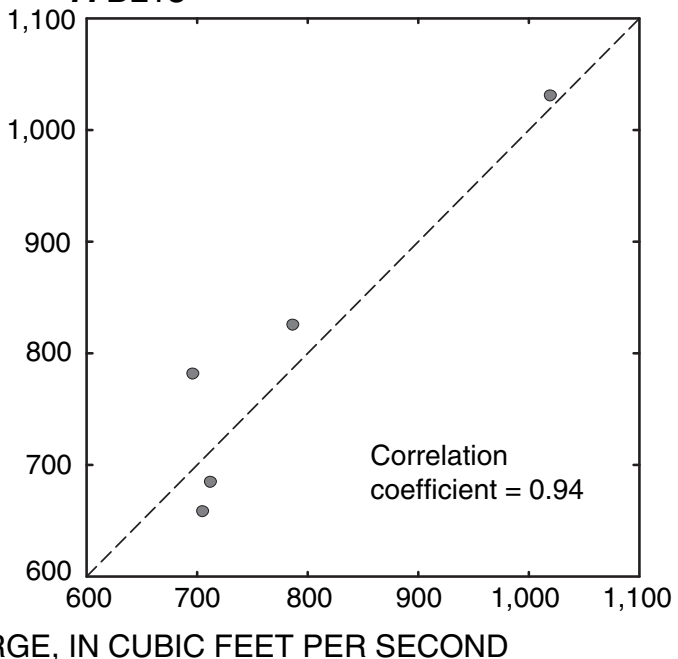

Figure 13. Relation between simulated and observed or computed annual mean discharge at streamflowgaging stations $A$, Quinsigamond River at North Grafton, Mass. (QU1A, 01110000); B, Blackstone River at Millbury, Mass. (BL2B, 01109730); C, Nipmuc River near Harrisville, R.I. (NI1A, 01111300); D, Branch River at Forestdale, R.I. (BR2A, 01111500); E, Blackstone River at Woonsocket, R.I. (BL9A, 01112500); and F, Blackstone River at Pawtucket, R.I. (BL13, 01113895). Dashed line shows the 1-to-1 relation between simulated and observed or computed discharge. 


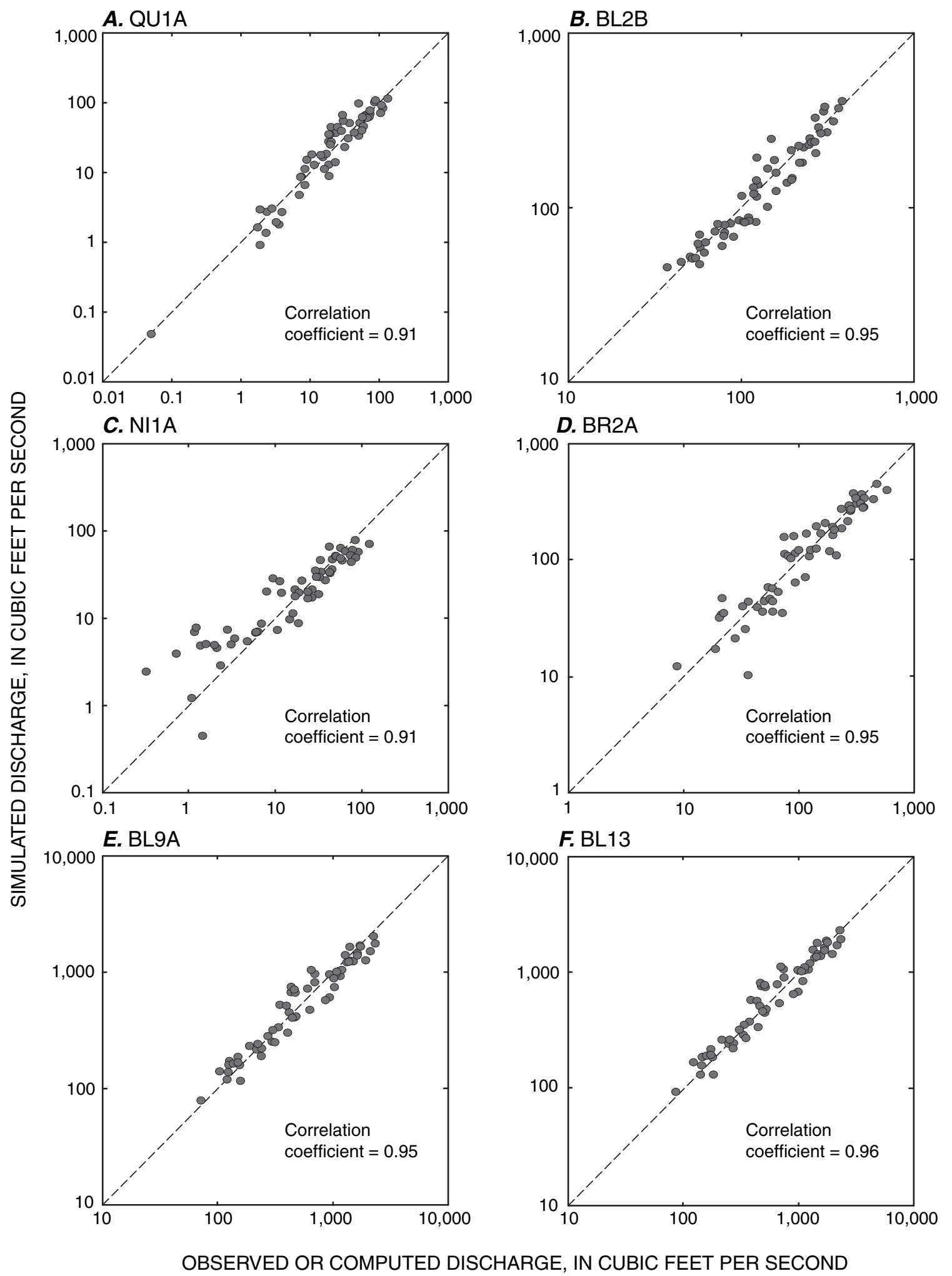

Figure 14. Relation between simulated and observed or computed monthly mean discharge at streamflowgaging stations $A$, Quinsigamond River at North Grafton, Mass. (QU1A, 01110000); $B$, Blackstone River at Millbury, Mass. (BL2B, 01109730); C, Nipmuc River near Harrisville, R.I. (NI1A, 01111300); D, Branch River at Forestdale, R.I. (BR2A, 01111500); E, Blackstone River at Woonsocket, R.I. (BL9A, 01112500); and F, Blackstone River at Pawtucket, R.I. (BL13, 01113895). Dashed line shows the 1-to-1 relation between simulated and observed or computed discharge. 
station) to 0.96 (Blackstone River at Pawtucket, R.I. station). Flows are slightly undersimulated for the months with the highest flows at most of these stations. Because the study focus is on the effects of development and land-use change on low flows, the agreement between observed and simulated discharge during the wet months was considered adequate. Monthly mean discharge was oversimulated on average by 8.8 percent at the Quinsigamond River at North Grafton, Mass. station, 57 percent at the Nipmuc River near Harrisville, R.I. station, 3.3 percent at the Branch River at Forestdale, R.I. station, 3.7 percent at the Blackstone River at Woonsocket, R.I. station, and 7.6 percent at the Blackstone River at Pawtucket, R.I. station for the calibration period. Monthly mean discharge at the Blackstone River at Millbury, Mass. station was undersimulated on average by 1.8 percent for the calibration period. These errors are calculated as the mean of the percent differences for each month in the calibration period. The NashSutcliffe coefficients indicate that the model accounted for 79 percent (Nipmuc River near Harrisville, R.I.) or better of the variation in the observed monthly mean discharge at these six stations (table 12).

\section{Daily Mean Discharge}

Hydrographs of observed and simulated daily mean discharges indicate that the model performed well over a range of flows of about three orders of magnitude (fig. 15). Observed daily mean discharges at the stations shown in figure 15 ranged from $0.03 \mathrm{ft}^{3} / \mathrm{s}$ (September 12, 2001) at the Quinsigamond River at North Grafton, Mass. station to $8,320 \mathrm{ft}^{3} / \mathrm{s}$ (March 23, 2001) at the Blackstone River at Pawtucket, R.I. station. The Nash-Sutcliffe coefficient indicated that the model explained 51 percent (Blackstone River at Millbury, Mass.) to 78 percent (Blackstone River at Woonsocket, R.I.) of the variation in the observed daily mean discharge at these stations (table 13).

The range in the magnitude of model errors for the 15 stations in the basin is the result of attempting to achieve a reasonable calibration across the basin (table 13); improvements in model error at a given location often worsened the model performance at other locations. In general, there were more discrepancies between observed and simulated daily mean discharge at stations that were simulated with climatological data from KPVD. For example, the difference between simulated and observed flows during the latter part of 2001 is relatively large at all stations with drainage areas in the southern part of the basin. This appears to indicate that the KPVD precipitation record, which is measured $10 \mathrm{mi}$ south of the basin, is not always representative of day-to-day precipitation in the southern part of the basin. In other instances, further adjustments to the model were not made because of uncertainty in the measured data. For example, the spring recession in 1999 was oversimulated at the Branch River at Forestdale, R.I. station, but this discrepancy could be the result of flow regulation in the basin. Overall, however, there is good agreement between simulated and observed spring hydrograph recessions at all stations for 1997-2001, indicating that the storage processes in the basin are reasonably well represented in the model.

Scatter plots generally show good agreement between observed and simulated daily mean discharges over the observed range of flow (fig. 16). Correlation coefficients ranged from 0.78 (Nipmuc River near Harrisville, R.I. station) to 0.89 (Blackstone River at Pawtucket, R.I. station). At the Nipmuc River near Harrisville, R.I. station, the model consistently oversimulated low flows (fig. 16C). Possible explanations include (1) underflow (ground-water flow through the aquifer) that bypasses the streamflow-gaging station, thus causing the model to oversimulate low flows, (2) more seasonal evapotranspiration losses from storage in wetlands than is represented by the model, or (3) some combination of these factors.

Flow-duration curves show the percentage of time a specified discharge is equaled or exceeded (fig. 17). These plots represent the combined effects of climate, surficial geology, topography, and hydrologic conditions such as anthropogenic stresses on the distribution of the magnitude of flow through time (Searcy, 1959). Overall, the flow-duration curves of simulated daily mean discharge closely match the observed discharge (fig. 17). The largest discrepancies are at the extreme high and low flows. At extreme low flows (discharges that are exceeded about 98 percent of the time), the flow-duration curve for simulated discharges lies above the curve for observed discharges at all stations, but the oversimulation of low flows was very small at the Quinsigamond River at North Grafton, Mass., Branch River at Forestdale, R.I., Blackstone River at Woonsocket, R.I., and Blackstone River at Pawtucket, R.I. stations. Low-flow discrepancies were larger at the Nipmuc River near Harrisville, R.I. station (for flows exceeded 50 percent of the time) and the Blackstone River at Millbury, Mass. station (for flows exceeded 90 percent of the time) (fig. 17). As discussed above, these discrepancies may partially result from errors associated with the measured streamflow record at the Nipmuc River near Harrisville, R.I. station, and the computed streamflow record at the Blackstone River at Millbury, Mass. station. At extreme high flows (discharges that are exceeded only about 0.2 percent of the time), the model undersimulated flow at the Nipmuc River near Harrisville, R.I. station and Branch River at Forestdale, R.I. station, and oversimulated flow at the Blackstone River at Millbury, Mass. and Pawtucket, R.I. stations (fig. 17).

\section{Simulated Hydrologic Response Unit Water Budgets}

Parameter values assigned primarily to the pervious land segments determine the predominant pathways and rates of flow to streams, and the magnitudes of losses of water by evapotranspiration. For example, discharge to streams from HRUs in areas 
underlain by sand and gravel is dominated by active groundwater flow mainly because the parameter that controls the infiltration rate (INFILT) is set to a high value (appendix 1), which allows more available moisture to reach subsurface flow and storage components. Hydrologic budgets computed from the major discharge and evapotranspiration components illustrate the hydrologic response characteristics of each HRU and the relative influence of the various HRUs in the Blackstone River Basin model. The major discharge components from PERLNDs to streams are active ground-water flow (AGWO), interflow (IFWO), and surface runoff (SURO), and the major evapotranspiration components are losses from lower-zone storage (LZET), upper-zone storage (UZET), and interception storage (CEPE). Total discharge is represented by the sum of the discharge components. Total evapotranspiration is represented by the sum of the evapotranspiration components. All discharge to streams from IMPLNDs is from surface runoff. The moisturesupply (SUPY) parameter represents total moisture supply to an HRU. Deep ground-water discharge (IGWI) was specified by use of the DEEPFR parameter from PERLNDs 1, 4, 5, 7, 8, $12,13,15$, and 16 to account for the presence of sewers receiving ground-water infiltration. Water was added to lower-zone storage in PERLNDs 6, 9, 14, and 17 by use of the lower-zone lateral input (LZLI) parameter to account for septic effluent from residential areas on public water systems.

Discharge and evapotranspiration components computed for the HRUs in the model were compiled for the mean annual water budget for 1997-2001 (fig. 18), March 2001, a wet month (fig. 19), September 1998, a dry month (fig. 20), and mean monthly budgets for 1997-2001 for four of the largest PERLNDs in the basin (figs. 21 through 24). The four PERLNDs in figures 21 through 24 represent forest overlying till (PERLND 3), forest overlying sand and gravel (PERLND 11), commercial-industrial-transportation (PERLND 1), and medium- to low-density residential overlying till (PERLND 4), respectively. Discharge (flow) components are shown as positive quantities, and evapotranspiration components are shown as negative quantities. Values for the HRUs shown in figures 18 through 24 are averages of the values from the individual HRUs in the northern (KORH climatological data) and southern (KPVD climatological data) parts of the basin.

The mean annual water budgets show that the underlying geologic material (sand and gravel or till) strongly affects the hydrologic response of the PERLND; budgets are similar for PERLNDs overlying till and for PERLNDs overlying sand and gravel, but the two groups are distinctly different from each other (fig. 18). Discharge per unit area to streams from PERLNDs overlying sand and gravel averaged about 93 percent from active ground-water flow, about 7 percent from interflow, and less than 0.1 percent from surface runoff (fig. 18A). Discharge per unit area to streams from PERLNDs overlying till averaged about 34 percent from active groundwater flow, about 56 percent from interflow, and 10 percent from surface runoff. Discharge per unit area to streams from commercial-industrial-transportation areas (PERLND 1) was dominated by interflow ( 55 percent) with approximately equal contributions from surface runoff and active ground-water flow (28 and 17 percent, respectively) (fig. 18A).

Simulated losses by sewer infiltration (water lost from the basin by use of the DEEPFR parameter) per unit area in PERLNDs overlying sand and gravel (PERLNDs 12, 13, 15, and 16) averaged about 51 percent of the total discharge to streams. Simulated losses to sewer infiltration per unit area in PERLNDs overlying till (PERLNDs 4, 5, 7, and 8) averaged about 13 percent of the total discharge to streams. Simulated losses to sewer infiltration per unit area in commercialindustrial-transportation areas (PERLND 1) averaged about 8.8 percent of total discharge to streams. PERLNDs $1,4,5$, $7,8,12,13,15$, and 16 cover 16.7 percent of the basin area (table 9). The total loss from these PERLNDs over the entire basin averaged $17.0 \mathrm{Mgal} / \mathrm{d}$.

The relative magnitudes of the discharge components indicate that PERLNDs underlain by till and the commercialindustrial-transportation PERLND will produce larger storm flows (more discharge from interflow [IFWO] and surface runoff [SURO]) and smaller low flows (less discharge from active ground-water flow [AGWO]) than PERLNDs underlain by sand and gravel. There is less variability in losses from the major evapotranspiration components than discharge components among the PERLNDs. Evapotranspiration losses per unit area were mainly from lower-zone storage in PERLNDs overlying by sand and gravel, and were more equally distributed between upper-zone and lower-zone storage in PERLNDs overlying till (fig. 18A). Losses from interception storage were similar and relatively minor in all PERLNDs.

The simulated mean annual runoff from the basin (excluding wetland and open-water areas) was 23.1 in. for 1997-2001, of which about 44 percent (10.1 in.) was from forested areas overlying till, and about 11 percent (2.5 in.) was from forest overlying sand and gravel (fig. 18b). Overall, PERLNDs overlying till accounted for 67 percent of discharge to streams, PERLNDs overlying sand and gravel accounted for 21 percent, IMPLNDs accounted for 9 percent, and commercial-industrialtransportation areas for the remaining 3 percent. Forested areas accounted for about 63 percent (12.2 in.) of the mean annual ET loss (19.5 in.) from the basin during this period. Thus, because of the large amount of forested acreage in the basin and associated large fluxes of water, the hydrologic response of forested areas overlying till strongly affects the basin water budget.

The water budget for the wet month (March 2001) (fig. 19) is fairly similar to the mean annual water budget (fig. 18). Discharge per unit area from PERLNDs overlying sand and gravel was dominated by active ground-water flow, whereas discharge per unit area from PERLNDs overlying till was more evenly distributed among the flow components, with interflow being the dominant component. However, there was less total discharge to streams from areas underlain by sand and gravel because more water was entering ground-water storage (fig. 19A). In contrast to the mean annual water budget, only 

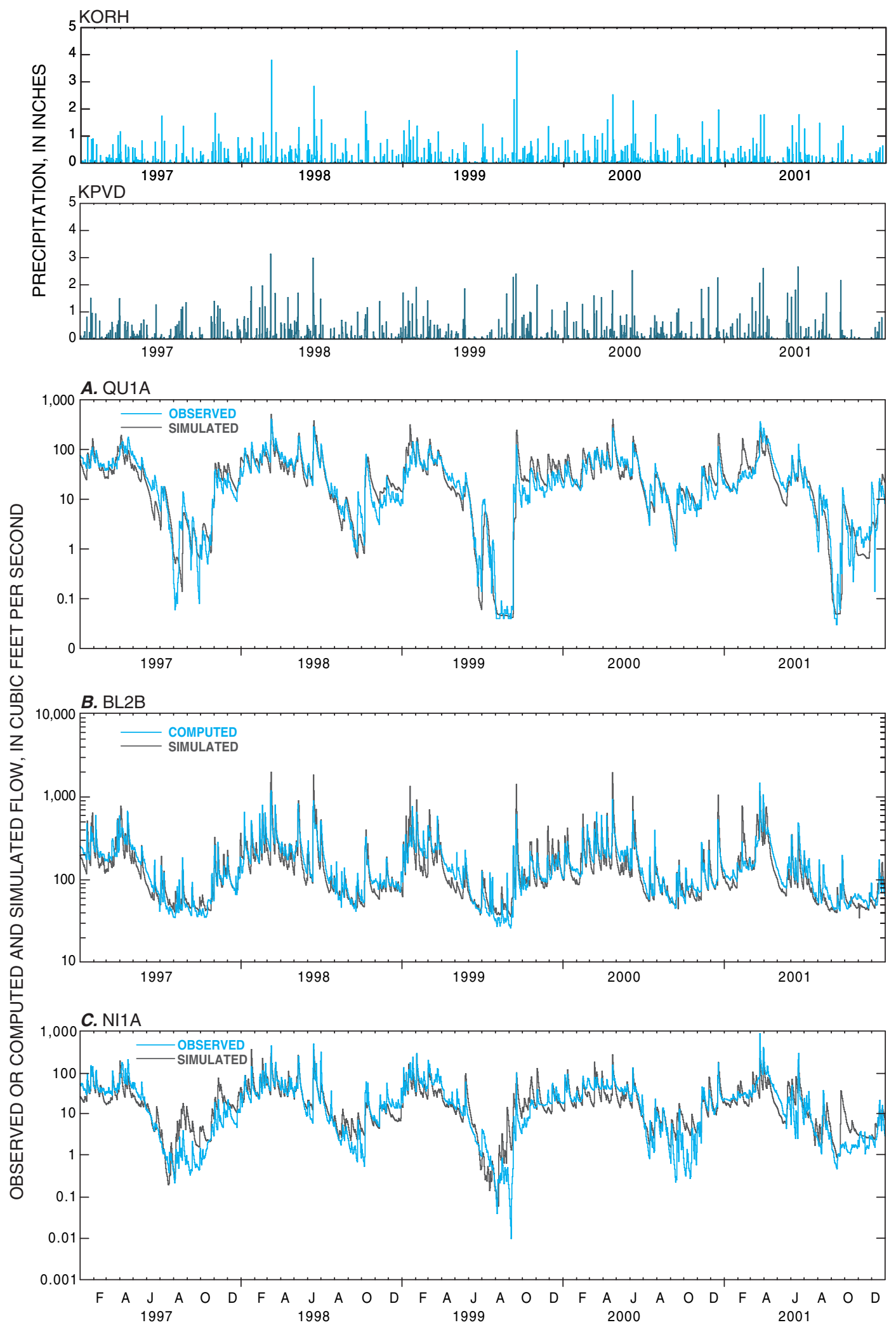

Figure 15. Daily precipitation at Worcester Regional Airport, Worcester, Mass. (KORH), and T.F. Green Regional Airport, Warwick, R.I. (KPVD), and simulated and observed or computed daily mean discharge at streamflow-gaging stations $A$, Quinsigamond River at North Grafton, Mass. (QU1A, 01110000);

B, Blackstone River at Millbury, Mass. (BL2B, 01109730); C, Nipmuc River near Harrisville, R.I. (NI1A, 01111300); D, Branch River at Forestdale, R.I. (BR2A, 01111500); E, Blackstone River at Woonsocket, RI (BL9A, 01112500); and F, Blackstone River at Pawtucket, R.I. (BL13, 01113895). 

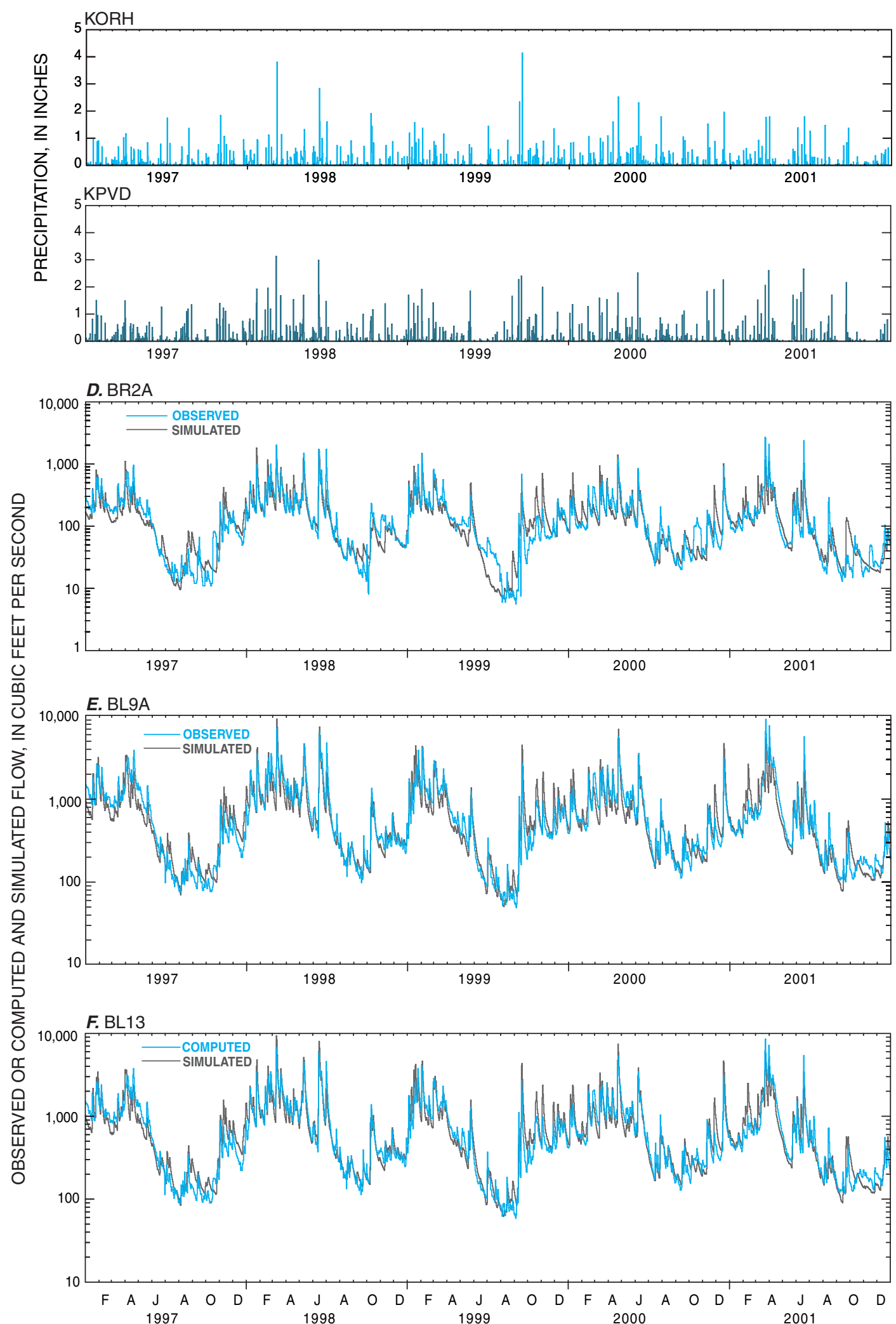

Figure 15. Daily precipitation at Worcester Regional Airport, Worcester, Mass. (KORH), and T.F. Green Regional Airport, Warwick, R.I. (KPVD), and simulated and observed or computed daily mean discharge at streamflow-gaging stations $A$, Quinsigamond River at North Grafton, Mass. (QU1A, 01110000); B, Blackstone River at Millbury, Mass. (BL2B, 01109730); $C$, Nipmuc River near Harrisville, R.I. (NI1A, 01111300); D, Branch River at Forestdale, R.I. (BR2A, 01111500); E, Blackstone River at Woonsocket, RI (BL9A, 01112500); and F, Blackstone River at Pawtucket, R.I. (BL13, 01113895).—Continued 
A. QU1A
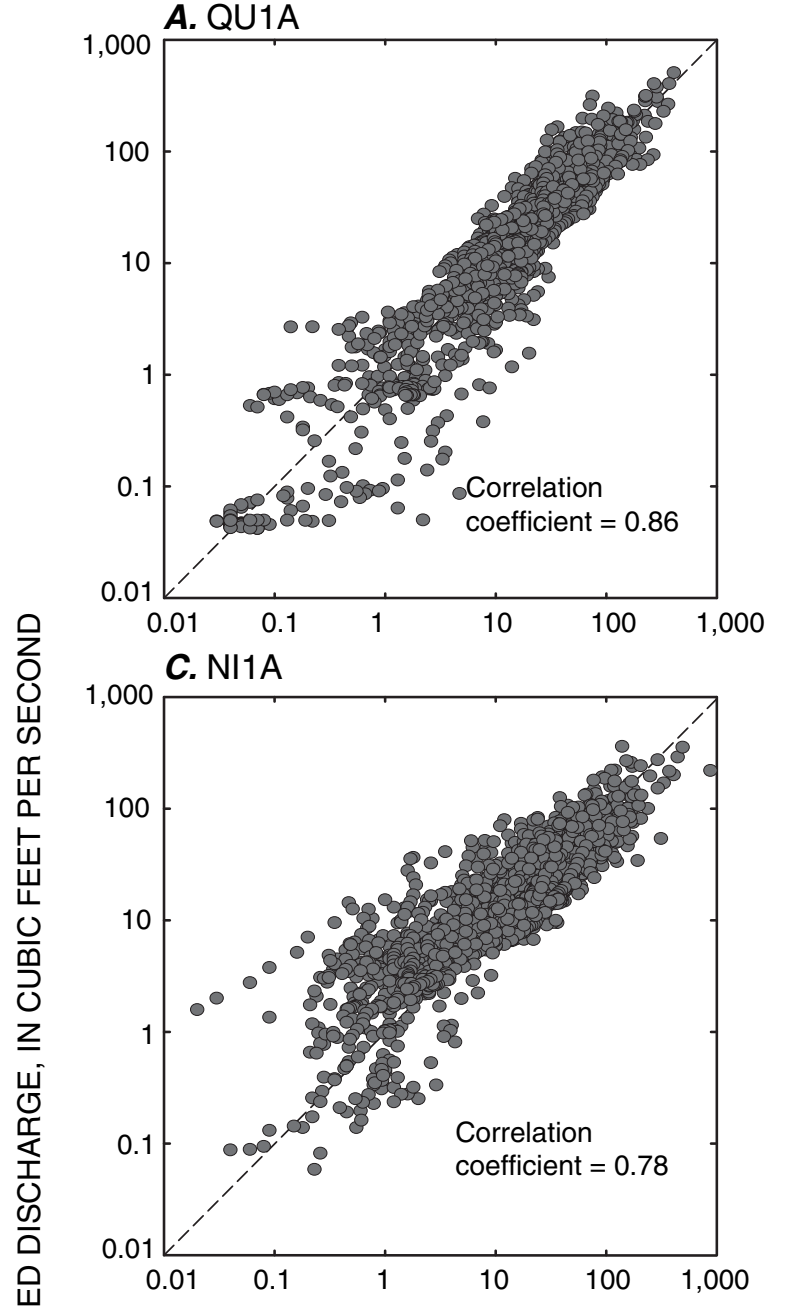

$\stackrel{5}{\stackrel{5}{5}}$

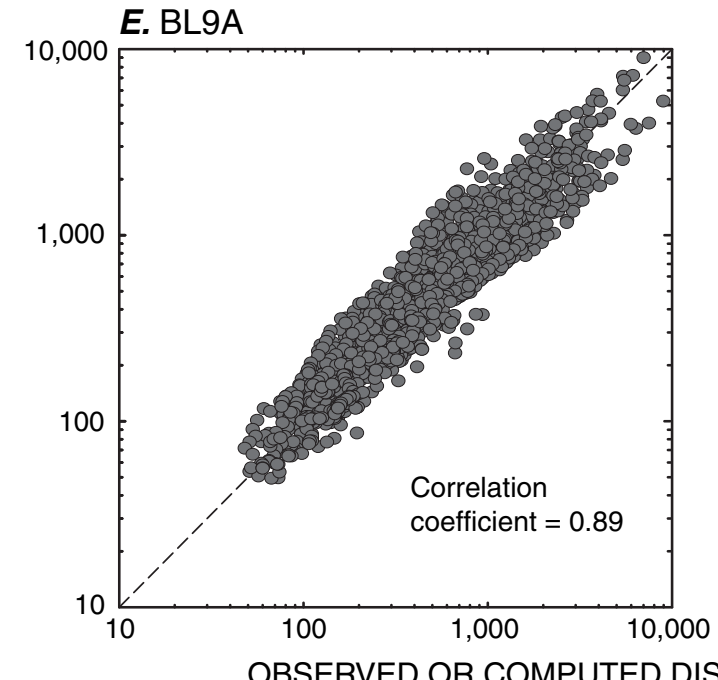

B. BL2B

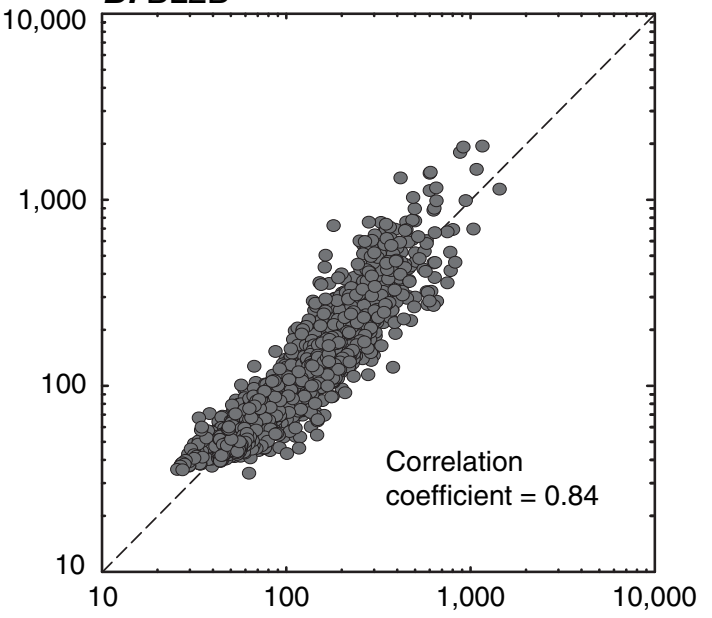

D. BR2A

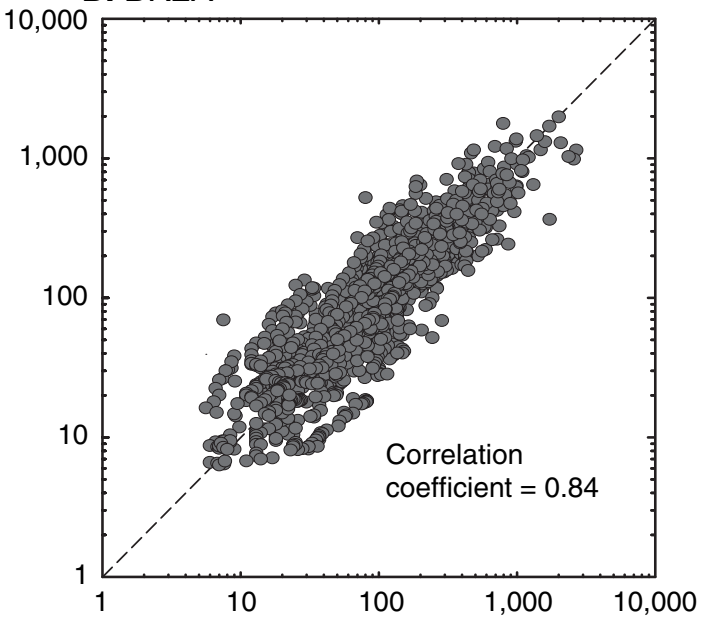

F. BL13

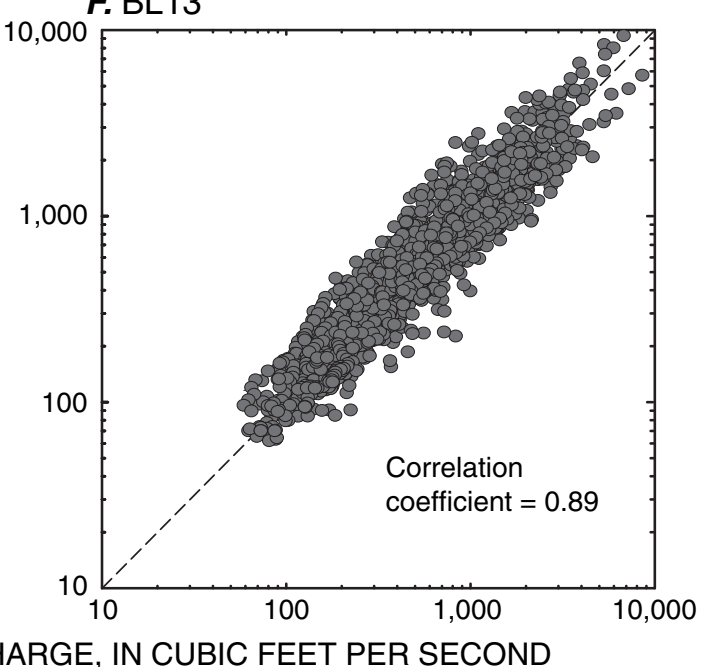

Figure 16. Relations between simulated and observed or computed daily mean discharge at streamflowgaging stations $A$, Quinsigamond River at North Grafton, Mass. (QU1A, 01110000); $B$, Blackstone River at Millbury, Mass. (BL2B, 01109730); C, Nipmuc River near Harrisville, R.I. (NI1A, 01111300); D, Branch River at Forestdale, R.I. (BR2A, 01111500); E, Blackstone River at Woonsocket, R.I. (BL9A, 01112500); and F, Blackstone River at Pawtucket, R.I. (BL13, 01113895). Dashed line shows the 1-to-1 relation between simulated and observed or computed discharge. 
A. QU1A

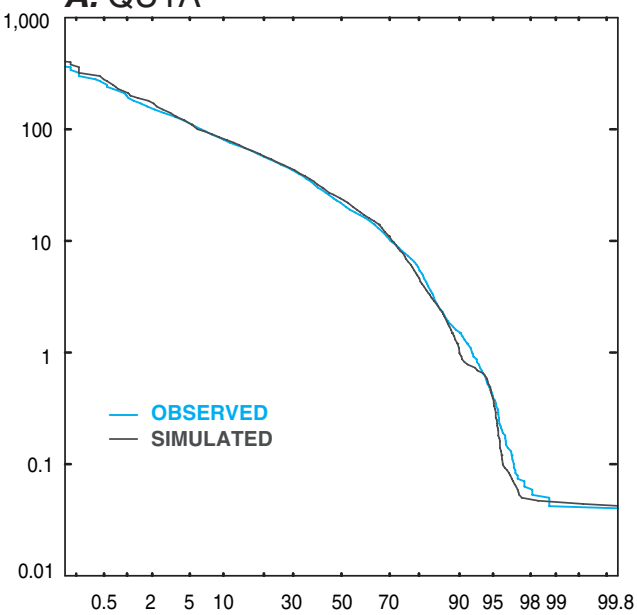

C. NI1A

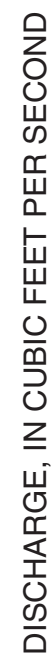

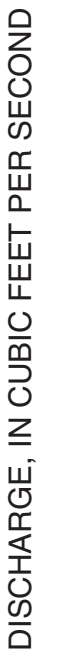

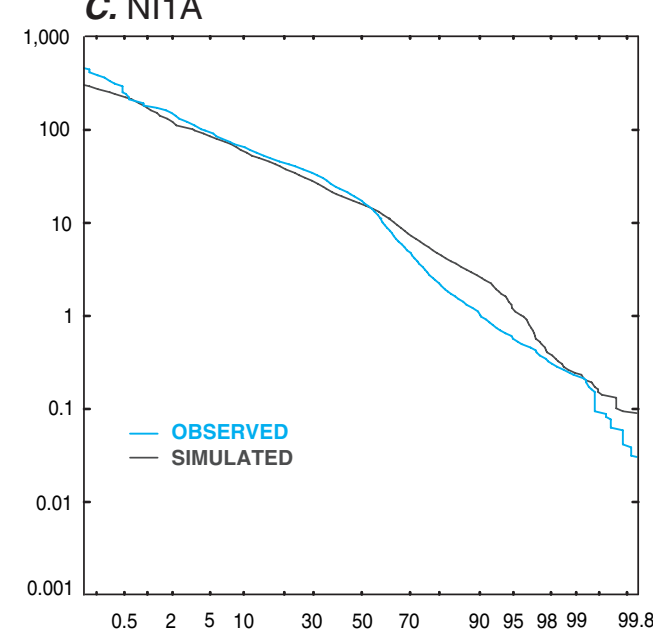

E. BL9A

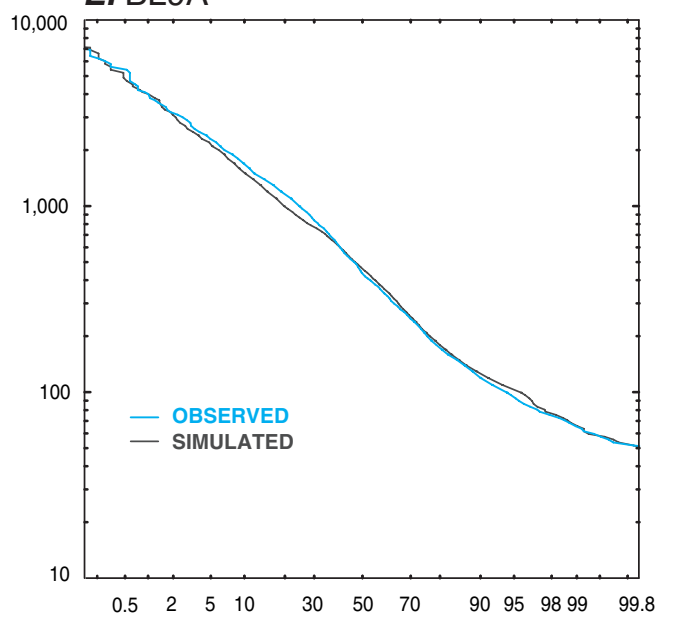

B. BL2B

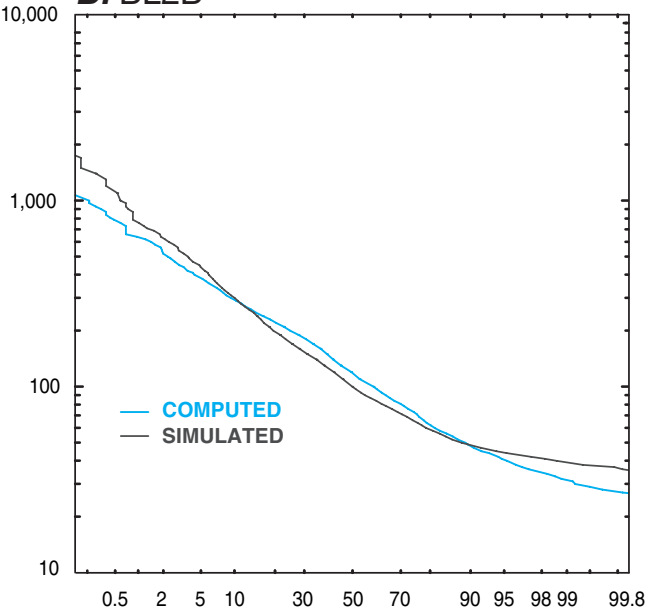

D. BR2A

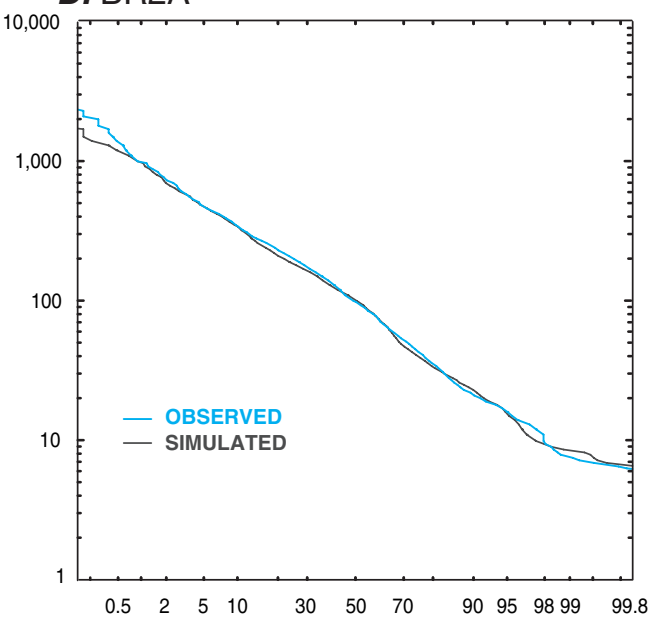

F. BL13

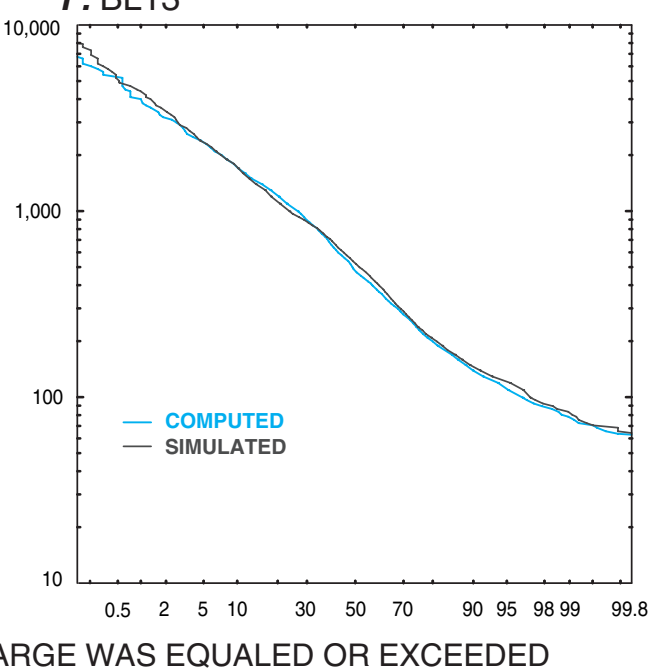

Figure 17. Flow-duration curves for simulated and observed or computed daily mean discharges at streamflow-gaging stations $A$, Quinsigamond River at North Grafton, Mass. (QU1A, 01110000); B, Blackstone River at Millbury, Mass. (BL2B, 01109730); C, Nipmuc River near Harrisville, R.I. (NI1A, 01111300); D, Branch River at Forestdale, R.I. (BR2A, 01111500); E, Blackstone River at Woonsocket, R.I. (BL9A, 01112500); and F, Blackstone River at Pawtucket, R.I. (BL13, 01113895). 
A. Water budget per unit area
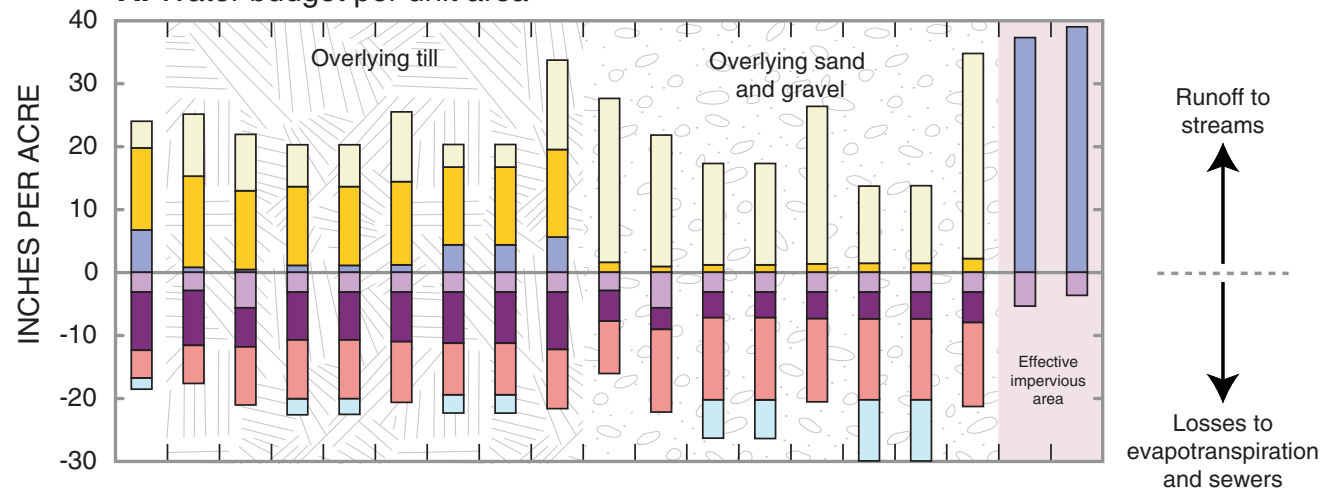

B. Basin water budget
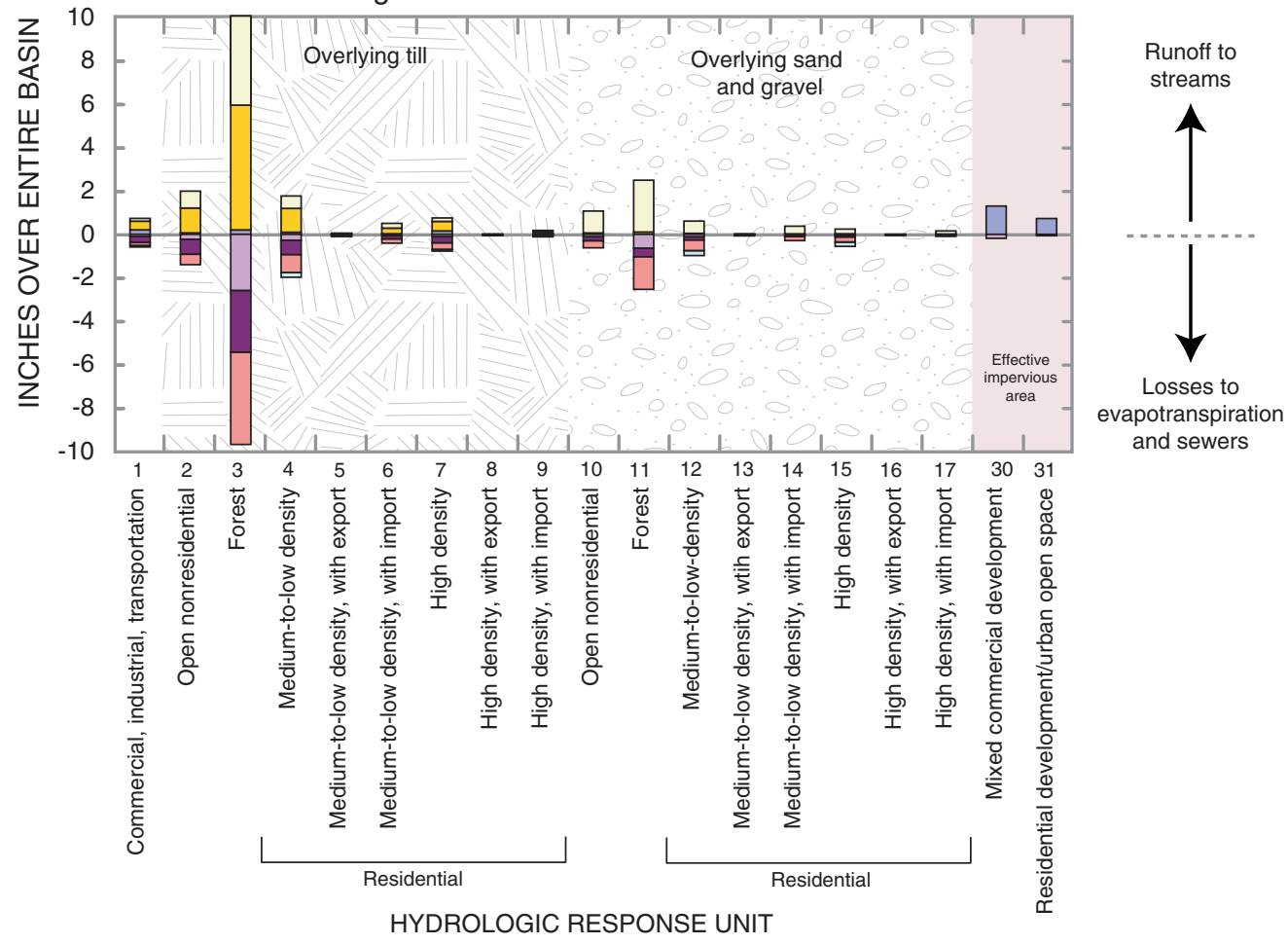

\section{EXPLANATION}

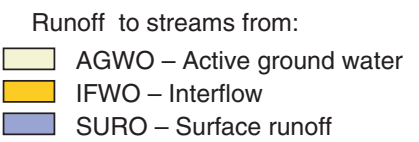

\footnotetext{
Losses to evapotranspiration from:

$\square$ CEPE - Interception

$\square$ UZET - Upper zone

$\square$ LZET - Lower zone

Losses to sewers from:

$\square$ IGWI - Deep ground-water

discharge (DEEPFR)
}

Figure 18. Mean annual water budget by component for 1997-2001 for each hydrologic response unit (HRU) simulated by the Hydrological Simulation Program-FORTRAN (HSPF) model of the Blackstone River Basin, in inches $A$, per acre; and $B$, over the entire basin. 


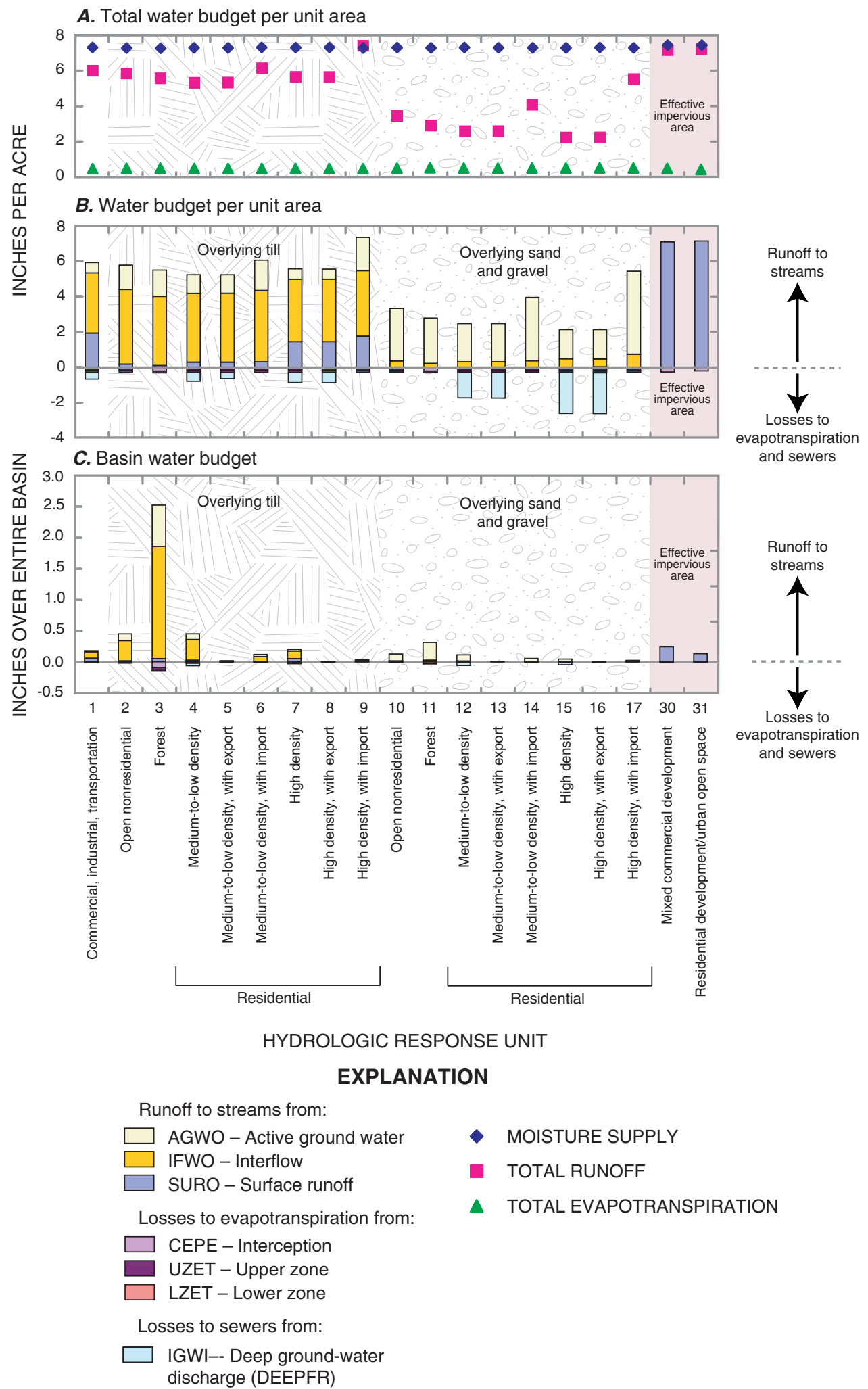

Figure 19. A wet month (March 2001) water budget for each hydrologic response unit (HRU) simulated by the Hydrological Simulation Program-FORTRAN (HSPF) model of the Blackstone River Basin, in inches $A$, per acre for moisture supply, total runoff to streams, and total losses to evapotranspiration; $B$, per acre for individual components of runoff to streams and losses to evapotranspiration and sewers; and $C$, over the entire basin for individual components of runoff to streams and losses to evapotranspiration and sewers. 
A. Total water budget per unit area
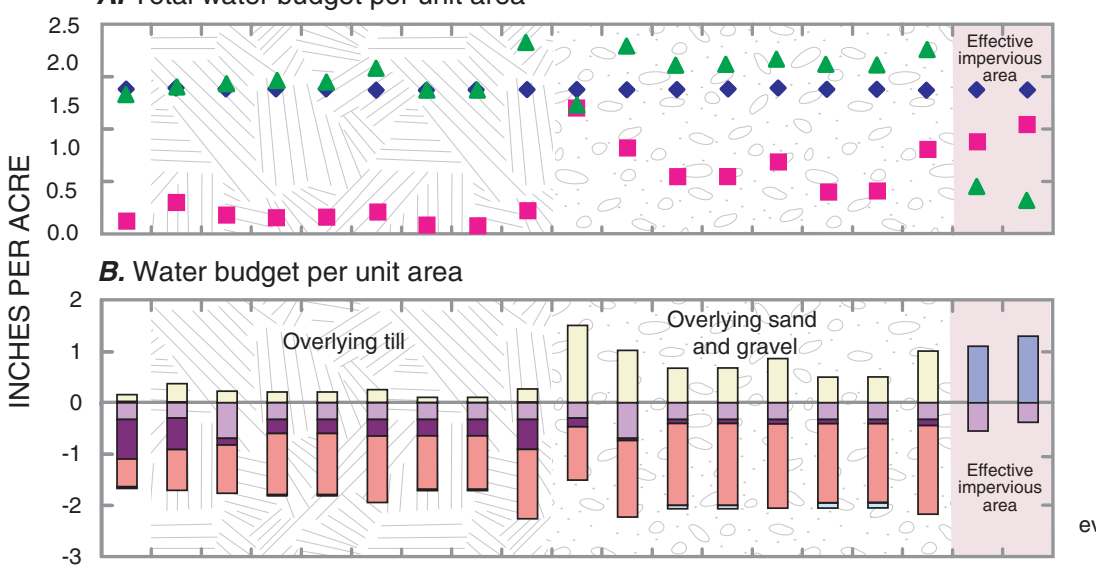

Runoff to

streams
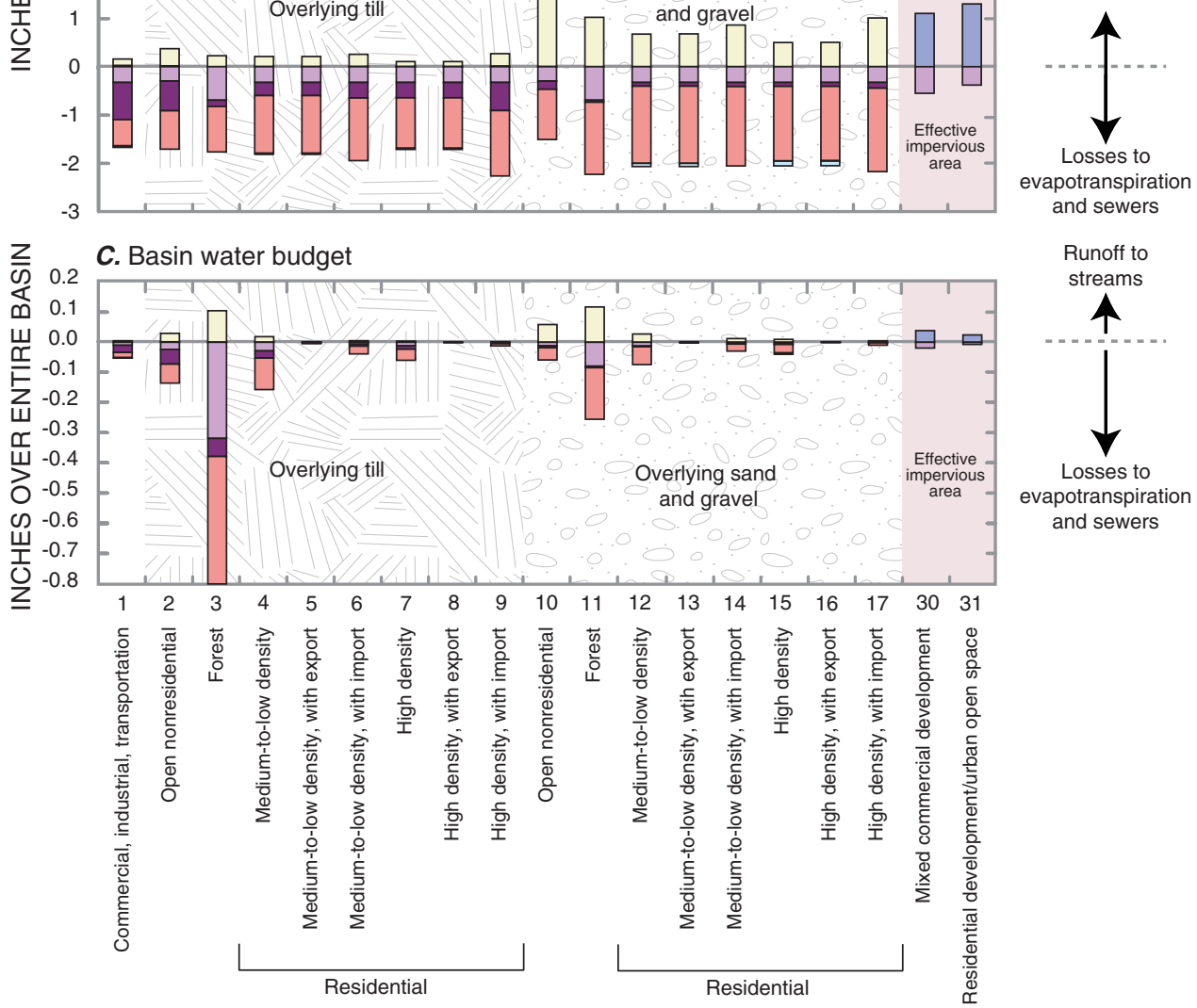

C. Basin water budget

Runoff to

streams

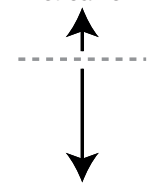

Losses to evapotranspiration and sewers

HYDROLOGIC RESPONSE UNIT

\section{EXPLANATION}

Runoff to streams from:

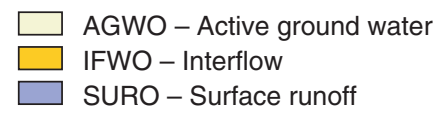

Losses to evapotranspiration from:

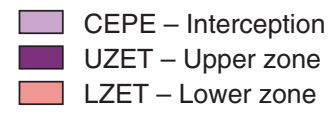

Losses to sewers from:

IGWI - Deep ground-water discharge (DEEPFR)

\author{
- MOISTURE SUPPLY \\ - TOTAL RUNOFF \\ - total EVAPOTRANSPIRATION
}

Figure 20. A dry month (September 1998) water budget for each hydrologic response unit (HRU) simulated by the Hydrological Simulation Program-FORTRAN (HSPF) model of the Blackstone River Basin, in inches $A$, per acre for moisture supply, total runoff to streams and total losses to evapotranspiration; $B$, per acre for individual components of runoff to streams and losses to evapotranspiration and sewers; and $C$, over the entire basin for individual components of runoff to streams and losses to evapotranspiration and sewers. 
a small amount of water (about 0.3 in.) was lost to evapotranspiration during March 2001. The moisture supply of 7.2 in. for the month was distributed, on average, between discharge to streams (5.0 in.), percolation to deep ground water (0.2 in.), evapotranspiration (0.3 in.), and inflow to storage (1.7 in.).

The water budget for the dry month (September 1998) (fig. 20) is substantially different than the mean annual and wet-month water budgets (figs. 18 and 19). Discharge per unit area to streams from all PERLNDs was composed almost entirely of active ground-water flow. In contrast to the wet month, there was less total discharge to streams from areas underlain by till because less water is available from groundwater storage in till relative to sand and gravel (fig. 20A). During dry periods, streamflow is generated predominantly by ground-water discharge from sand and gravel deposits. Evapotranspiration per unit area generally exceeds discharge to streams for all PERLNDs, and is dominated by losses from lower-zone storage. The moisture supply of $1.7 \mathrm{in}$. for the month was distributed, on average, between discharge to streams (0.58 in.), percolation to deep ground water (0.02 in.), evapotranspiration (1.74 in.). Because the sum of evapotranspiration and total discharge exceeded the moisture supply, water was removed from storage (0.64 in.). Evapotranspiration losses from forested areas dominate the basin water budget during the dry month (fig. 20C). This is because forests are areally extensive and have abundant deep-rooted vegetation.

The mean monthly water budgets for 1997-2001 illustrate the seasonal changes in discharges to streams and evapotranspiration losses and the corresponding gains or losses from storage. Forested areas (PERLNDs 3 and 11 in figs. 21 and 22, respectively) are characterized by high rates of evapotranspiration from lower-zone storage during the growing season resulting in rapid declines in the total discharge to streams as the summer progresses. During the first few months of the year, total discharge tracks the moisture supply closely, but begins diverging as evapotranspiration increases in the spring. From about May through September, the sum of evapotranspiration and total discharge exceeds the moisture supply, indicating that water is being removed from storage. As the growing season ends and evapotranspiration decreases, the sum of evapotranspiration and discharge fall well below the moisture supply, indicating that soil moisture is being replenished. This also is indicated by runoff which lags the total moisture supply in the fall and winter after evapotranspiration has decreased to its seasonal low. One notable difference between the forested PERLNDs is that there is a larger percentage of discharge from active ground-water flow in areas underlain by sand and gravel than in areas underlain by till, resulting in a flatter hydrograph with lower flows through the winter and higher flows through the summer and early fall (figs. 21A and 22A).

The mean monthly budget for PERLND 4 (medium- to low-density residential area overlying till; fig. 23) is very similar to PERLND 3 (forest overlying till; fig. 21). The similarity in the simulations indicates that medium- to low-density development, as represented in the model, does not significantly alter the hydrologic response to precipitation relative to undevel- oped, forested land; however, other possible changes that might accompany development, such as increased impervious area or decreased wetland area, are not represented. The net effect of low-density development is better understood by simulating the response of streamflow to changing land use in the basin.

The mean monthly water budget for commercialindustrial-transportation areas (PERLND 1) is characterized by less vigorous evapotranspiration during the summer months (fig. 24); however, because lower-zone storage is smaller, less water reaches ground-water storage. Total runoff, which is composed mainly of interflow and surface flow, declines sharply as the summer progresses. This condition also allows runoff to recover more rapidly in the fall and early winter in contrast to the forested PERLNDs. The hydrologic response of PERLND 1 generally is similar to the response of the till PERLNDs (figs. 18 through 20). A short period ( 2 months) when water is lost from storage takes place during late summer.

\section{Summary of Anthropogenic Water Use in Basin}

The magnitudes of the withdrawals and return flows compiled from external sources and included in the model provide an indication of the anthropogenic stress placed on the basin, and the overall quality and completeness of the water-use information. The total withdrawal rate for all the municipal and commercial/industrial withdrawals in the basin (table 5), minus the intrabasin transfers, averaged about $64 \mathrm{Mgal} / \mathrm{d}$ for 1997-2001. This value probably slightly underestimates the actual loss of water because minor withdrawals (for example, from agricultural water use) and consumptive losses associated with private wells were not included. The total return-flow rate for all the permitted municipal and commercial/industrial return flows in the basin (54 Mgal/d) (table 6), the transfers from the Nashua River Basin (13.7 Mgal/d; DSNs 405 and 1009), and the septic effluent in areas with public-water supplies (3.1 Mgal/d) averaged about $71 \mathrm{Mgal} / \mathrm{d}$ for 1997-2001. If the simulated flow derived from precipitation on the basin (ground-water infiltration to municipal sewers in the basin $(17.0 \mathrm{Mgal} / \mathrm{d})$ and inflows from combined-sewer areas in Worcester (4.9 Mgal/d) is subtracted from $71 \mathrm{Mgal} / \mathrm{d}$, the total return-flow rate to the basin was about $49 \mathrm{Mgal} / \mathrm{d}$ for 1997-2001. Thus, the total withdrawals exceeded the total return flows by roughly $15 \mathrm{Mgal} / \mathrm{d}$, indicating that there was a net export of water across basin boundaries.

In comparison, Barlow (2003) found that total withdrawals exceeded total returns by a factor of nearly 2 in the lower part of the basin. The significant export in the lower part of the basin is largely the result of water withdrawn by the Pawtucket Water Supply Board from the Abbott Run subbasin being used in communities that discharge their wastewater to the Narragansett Bay Commission wastewater-treatment facility at Bucklin Point, which is outside the basin. The closer balance for the basin as a whole indicates that there is a net import of water in the northern part of the basin, which is consistent with the $13.7 \mathrm{Mgal} / \mathrm{d}$ import of water from Kendall Reservoir to 


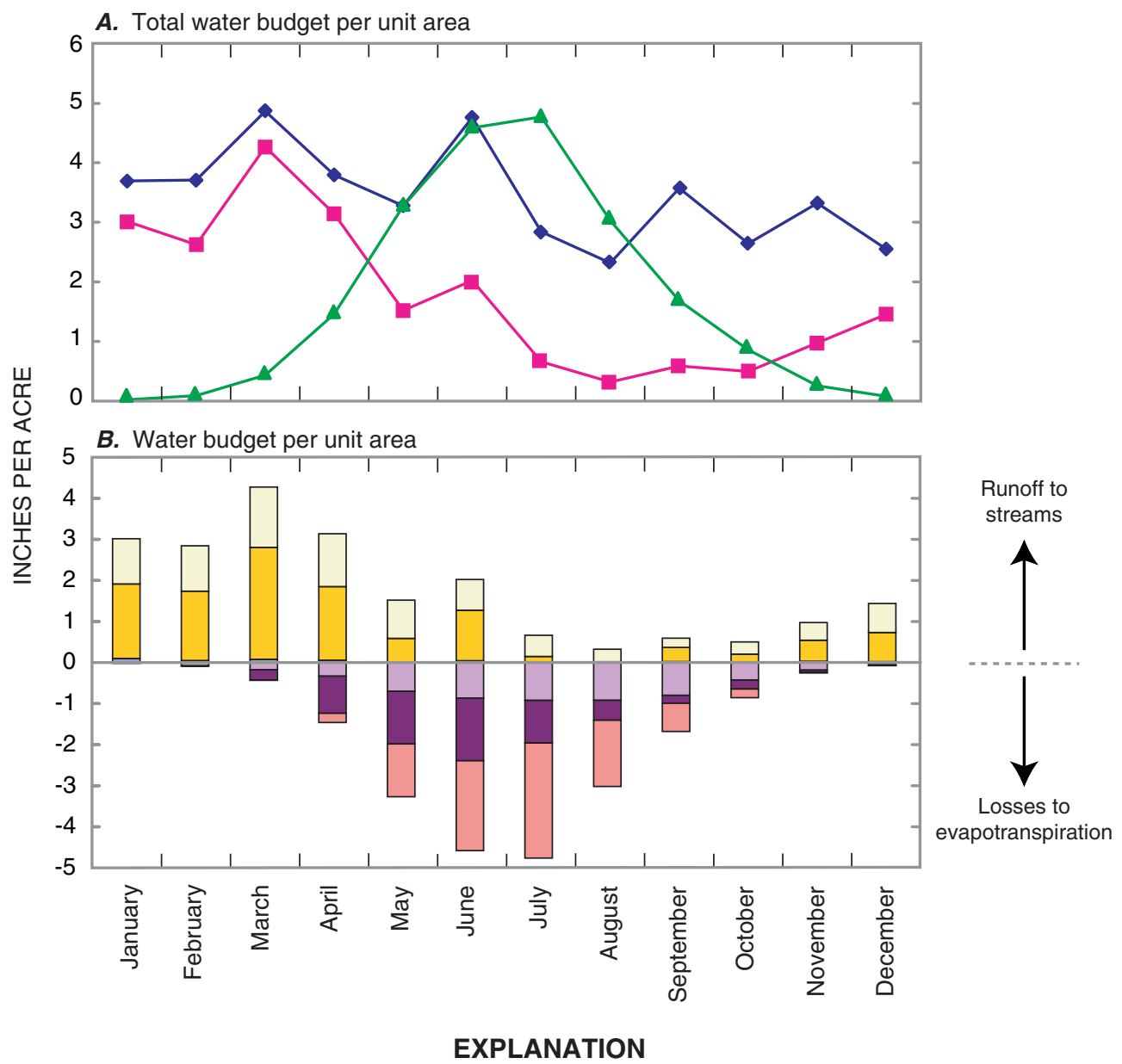

Runoff to streams from:

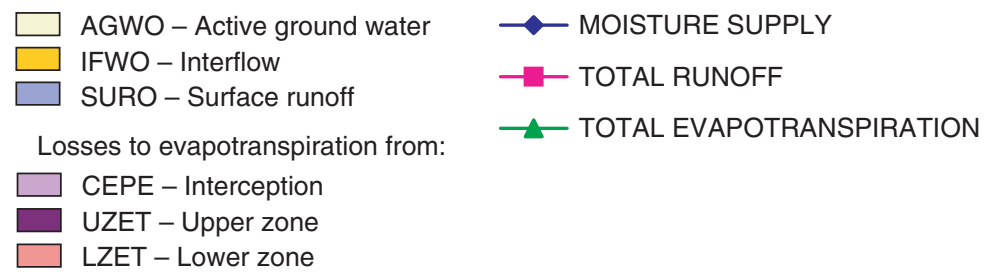

Figure 21. The mean monthly water budget for 1997-2001 for PERLND 3 (forest overlying till) simulated by the Hydrological Simulation Program-FORTRAN (HSPF) model of the Blackstone River Basin model, in inches $A$, per acre for moisture supply, total runoff to streams and total losses to evapotranspiration; and $B$, per acre for individual components of runoff to streams and losses to evapotranspiration. 


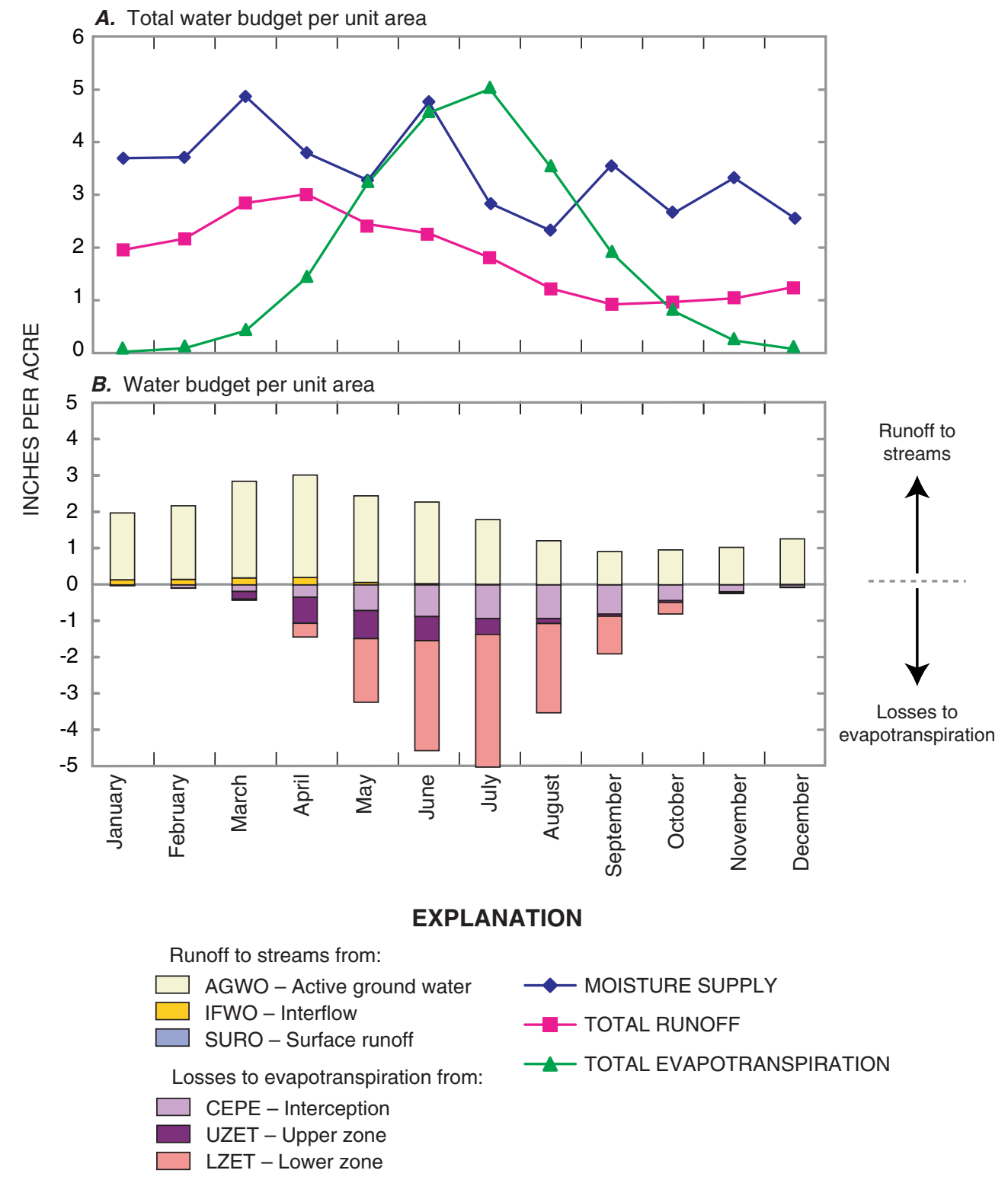

Figure 22. The mean monthly water budget for 1997-2001 for PERLND 11 (forest overlying sand and gravel) simulated by the Hydrological Simulation Program-FORTRAN (HSPF) model of the Blackstone River Basin, in inches $A$, per acre for moisture supply, total runoff to streams and total losses to evapotranspiration; and $B$, per acre for individual components of runoff to streams and losses to evapotranspiration. 


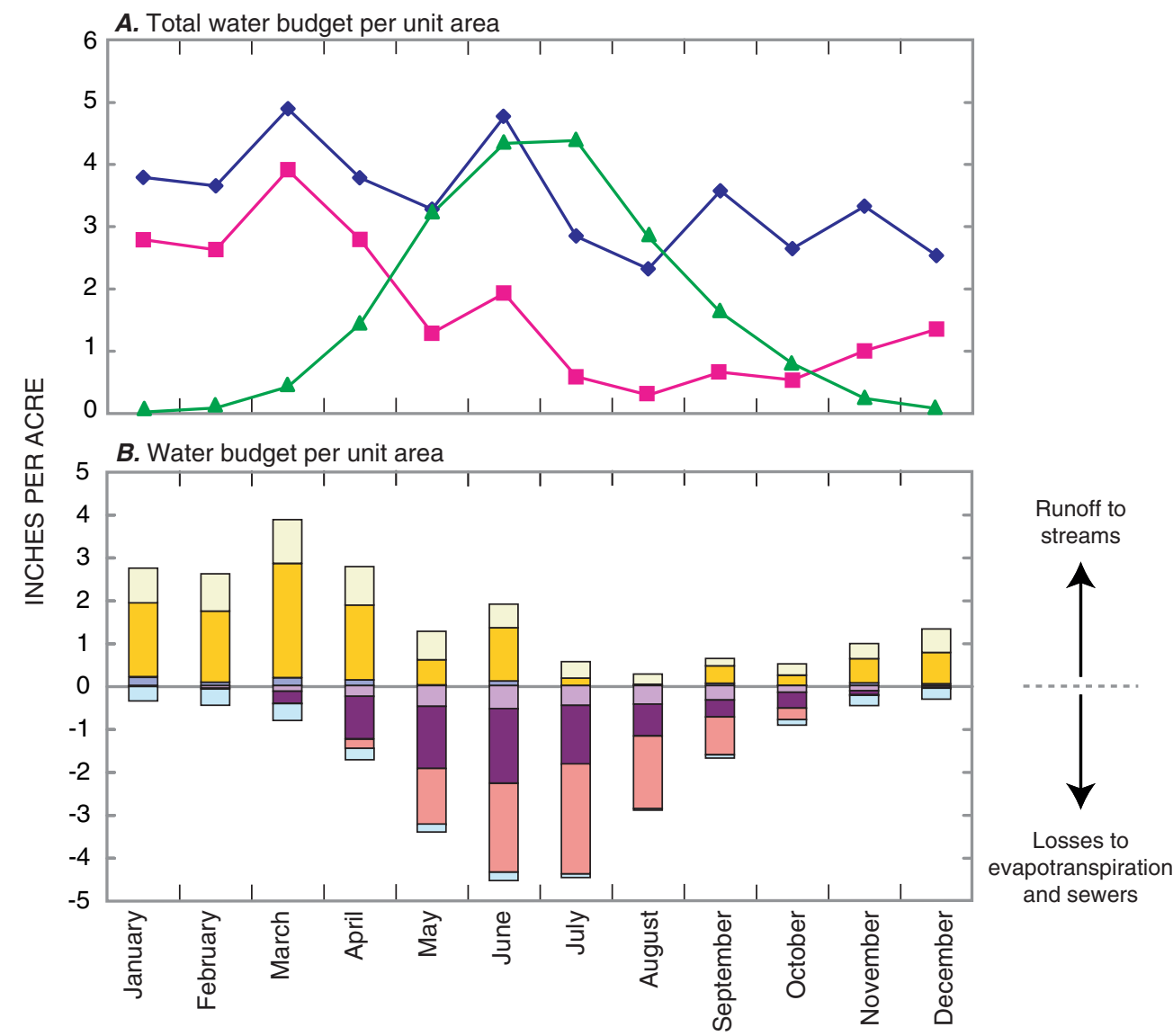

\section{EXPLANATION}

Runoff to streams from:

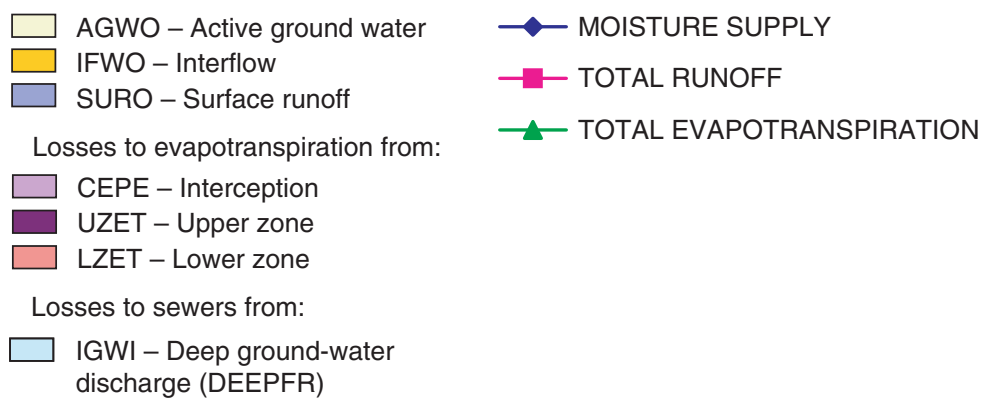

Figure 23. The mean monthly water budget for 1997-2001 for PERLND 4 (mediumto low-density residential areas with no import or export of water overlying till) simulated by the Hydrological Simulation Program-FORTRAN (HSPF) model of the Blackstone River Basin, in inches $A$, per acre for moisture supply, total runoff to streams and total losses to evapotranspiration; and $B$, per acre for individual components of runoff to streams and losses to evapotranspiration and sewers. 


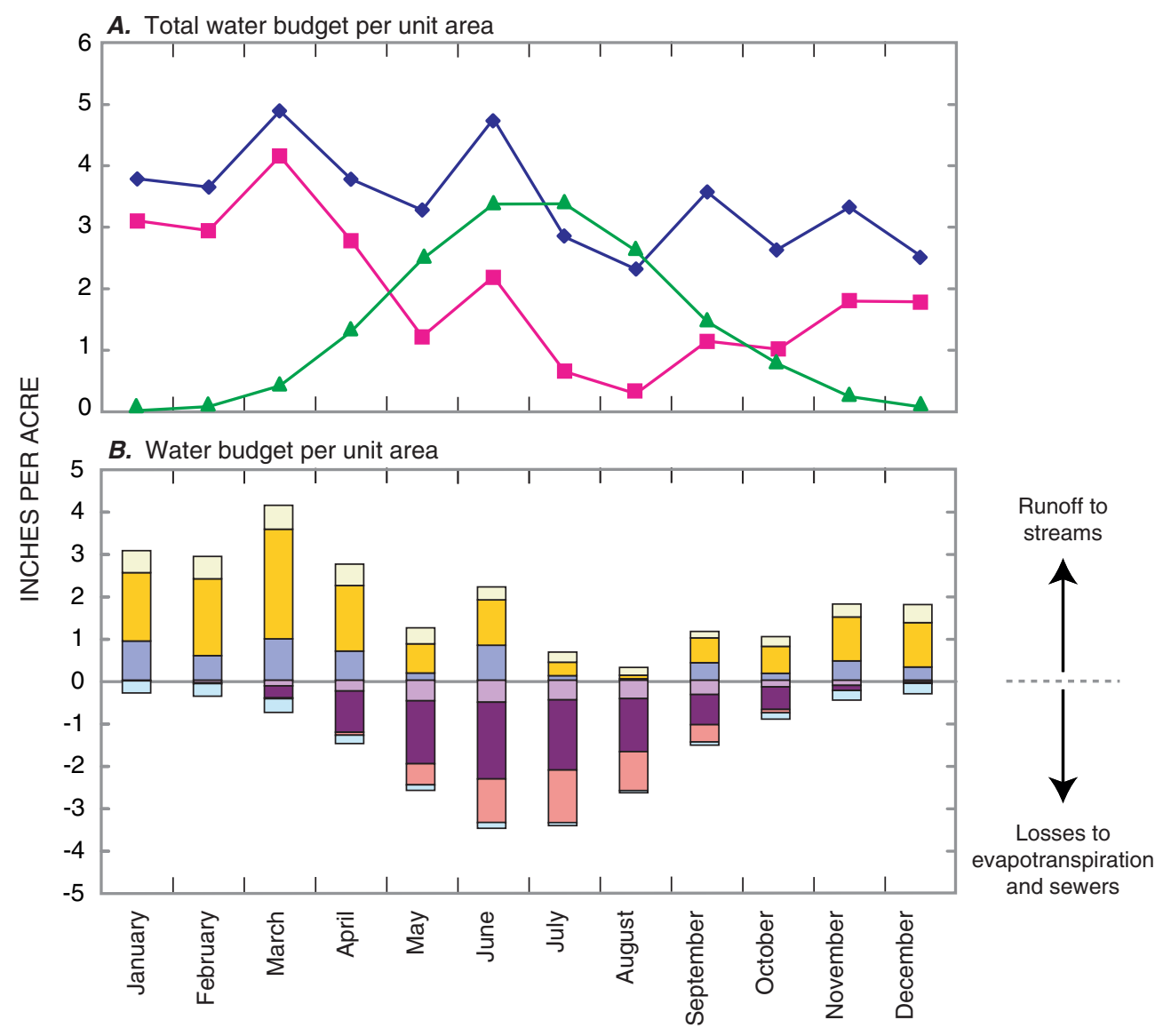

\section{EXPLANATION}

Runoff to streams from:

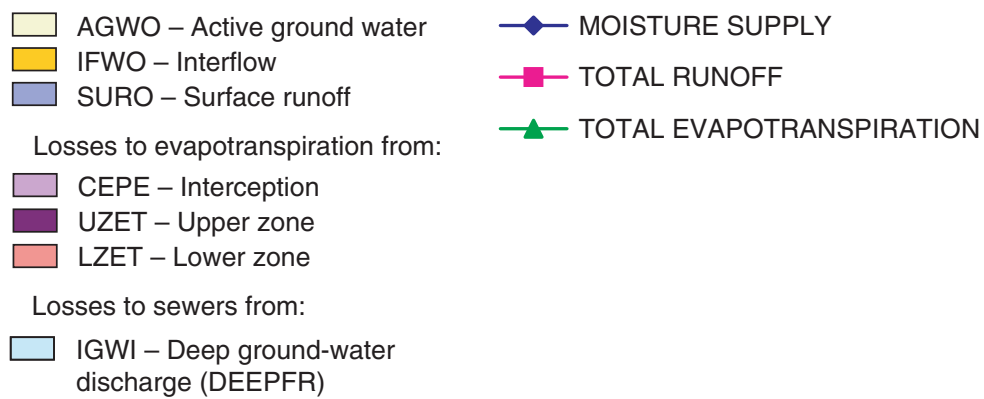

Figure 24. The mean monthly water budget for 1997-2001 for PERLND 1 (commercialindustrial-transportation areas) simulated by the Hydrological Simulation Program-FORTRAN (HSPF) model of the Blackstone River Basin, in inches $A$, per acre for moisture supply, total runoff to streams, and total losses to evapotranspiration; and $B$, per acre for individual components of runoff to streams and losses to evapotranspiration and sewers. 
the Worcester water-supply system. The imbalance in withdrawals and returns is small in comparison to the average rate of precipitation on the basin of $948 \mathrm{Mgal} / \mathrm{d}$ (42 in/yr) for the calibration period.

\section{Sensitivity of Model Results to Changes in Values of Parameters}

Sensitivity analysis determines the response of the modelsimulated discharge to changes in the values of parameters. Systematic perturbation of model parameters reveals the most influential parameters for a given model structure and set of basin characteristics. The Blackstone River Basin HSPF model is very similar in structure to the Ipswich River Basin model of Zarriello and Ries (2000). Both models represent wetlands as virtual RCHRESs and are constructed from a similar group of PERLNDs and IMPLNDs. Simulated flow budgets from both models indicate that subsurface discharge consisting of ground-water discharge (base flow) and interflow are the dominant flow components to stream reaches. The results of the sensitivity analysis conducted for the Ipswich River Basin model are therefore considered to be applicable to the Blackstone model. Overall, the Ipswich-River sensitivity analysis indicates that the changes in the parameters that affect groundwater and interflow recession cause the largest changes in various measures of model fit. These parameters include the active ground-water recession constant (AGWRC), the ground-water recession parameter that determines the degree of nonlinearity of the recession rate (KVARY), the coefficient that determines the amount of water that enters the ground from surface storage and becomes interflow (INTFLW), and the interflow recession constant (IRC). Uncertainties in these parameters will have the largest effect on model performance. Model results also are sensitive to changes in parameters that determine the amount of precipitation that eventually discharges as base flow or interflow; these include the infiltration parameter (INFILT), the lower-zone nominal storage parameter (LZSN), the upper-zone nominal storage parameter (UZSN), and the lower-zone evapotranspiration parameter (LZETP). Further explanation of these parameters can be found in Bicknell and others (2000). Zarriello and Ries (2000) found also that model results, particularly during low flows, were sensitive to the manner in which wetlands were represented in the model.

\section{Model Limitations}

Numerical watershed models necessarily simplify the complex processes and physical characteristics of a basin. Consequently, there are limitations to the types of questions that can be addressed by the model. Nonetheless, the model can be used effectively to address many water-resource management questions, provided that the limitations and uncertainties are considered. One uncertainty associated with complex watershed models such as HSPF is the possibility of constructing models with differing structures and parameter values that produce equally acceptable results; typically data needed to select the most appropriate model are lacking. Thus, the calibrated Blackstone River Basin HSPF model, which was developed to assess the effects of development and changing water and land use on streamflow, should be viewed as one of many possible representations of the basin and sets of HSPF parameters. Uncertainty also is inherent in the data used to develop and calibrate the model. These data include climatological data, water-use data, channel-geometry and other hydraulic data used to construct FTABLEs, and the geospatial data used to define the HRUs.

Uncertainty in the climatological data results from (1) the use of point measurements to represent variables that have a high degree of spatial variability, (2) the presence of regional climatic differences across the basin, (3) the presence of systematic measurement bias, or (4) some combination of these factors. Extrapolating a point measurement of precipitation over a large area of the basin disregards the spatial variability of the intensity and duration of precipitation events. The climatological data from KORH (Worcester Regional Airport) generally provided better agreement between simulated and observed flows in the northern part of the basin than the data from KPVD (T.F. Green Airport) in the southern part of the basin. Climatological conditions at KPVD, which is outside the basin, may differ appreciably from local conditions in the lower basin due to a regional gradient in weather patterns. The uncertainties in the climatological data may lead to error in simulating storms and daily streamflow in the basin; however, the model reasonably represents regional climatological conditions and therefore this error is inconsequential for long-term simulations of water-management alternatives.

Uncertainty in water-use data and simplification of the complexities of water use in the basin also affect calibrated parameter values. Known water withdrawals are removed directly from simulated streamflow. Similarly, known wastewater-return flows are added directly to simulated streamflow. For time-varying ground-water withdrawals, streamflow depletion was first calculated with the STRMDEPL program, which is subject to several simplifying assumptions; the accuracy of streamflow depletion calculated in this manner depends on the degree to which the underlying assumptions of STRMDEPL are met. For golf-course irrigation withdrawals, measured data were sparse, and the withdrawals for most courses could only be estimated. Septic effluent from households on public water supplies was added directly to lower-zone soil storage, and ground-water withdrawals from households on private wells and public sewer were subtracted directly from simulated streamflow. Residential water-use rates were based on household population densities, and per capita water-use estimates were obtained from other studies. Once these disparate water uses are accounted for in the model, the parameter values are adjusted to calibrate the model's response to precipitation and evapotranspiration. Therefore, parameter values can be skewed during calibration to compensate for inaccuracies in the water-use data (due to 
assumptions, reporting errors, or estimation of missing data) or inadvertent omission of major withdrawals or returns.

Model calibration and performance reflect the combined response of the PERLNDs, IMPLNDs, and reaches used to represent the basin. Most HSPF parameters, as well as IMPLND areas, cannot be measured independently and are obtained through the calibration process. In general, judgment based on hydrologic experience and results from previous HSPF studies are used to determine the parameter values for individual HRUs. Although agreement was good between observed and simulated flows for a wide range of flow conditions and HRU combinations, information was not available to calibrate individual HRUs. Therefore, simulation results from analyses in which one type of HRU is changed to another (such as a buildout scenario) or flow from an individual type of HRU is of interest (such as a water-quality study), have a high degree of uncertainty and should be interpreted cautiously to avoid reaching inaccurate conclusions.

Stage, storage, and discharge characteristics of stream reaches are determined from measured channel geometry to the extent possible, but the spatial variability of these characteristics cannot be measured or fully represented in the model. Similarly, stage, storage, and discharge characteristics of reservoir and wetland reaches were determined from available data to the extent possible, but for most reaches these data were not available and their values could only be estimated. Reservoirmanagement activities, such as seasonal water-level changes for recreational purposes or regulation for flood control or water-supply management, and run-of-river diversions for power generation or industrial use, also were not represented in the model. As part of the calibration process, storage-discharge relations were adjusted empirically in the 15 reaches with observed streamflow data; direct calibration of the other 35 reaches was not conducted. Thus, simulation results from ungaged areas of the basin have a high degree of uncertainty.

\section{Summary}

The 474.5 square mile Blackstone River Basin in southeastern Massachusetts and northern Rhode Island is experiencing rapid population and commercial growth throughout much of its area. This growth and the corresponding changes in landuse patterns are placing increasing stress on water resources in the basin and raising concerns about the future availability of water. Increased withdrawals needed to meet growing watersupply demand could adversely affect aquatic habitat, water quality, and the recreational value of the streams in the basin. To address these concerns, the U.S. Geological Survey, in cooperation with the Rhode Island Water Resources Board, developed a Hydrological Simulation Program-FORTRAN (HSPF) precipitation-runoff model of the Blackstone River Basin. The model will be used to study the effects of changing land and water use on streamflow and evaluate water-resources management alternatives.
In 2000, approximately 467,000 people lived in the Blackstone River Basin. Population is concentrated in Worcester, Massachusetts, and surrounding communities in the headwaters of the basin and in Woonsocket, Cumberland, and Pawtucket, Rhode Island, in the lower part of the basin. The eastern side of the basin, near the Route 495 corridor, is generally more developed and populated than the western side. State land-use data layers representing 1995-1999 indicate that land is predominantly forested (50.7 percent). The next largest land-use category is residential (21.3 percent), of which 14.7 percent is medium- to low-density residential and 6.6 percent is high-density residential; followed by open, non-residential (10.7 percent); forested and non-forested wetlands (7.7 percent); commercial-industrial-transportation (5.8 percent); and open water (3.8 percent). The hydrology of the watershed has been affected by the long history of industrial activity and development. Currently, hydrologic effects are caused by water withdrawals; wastewater-return flows; flow regulation for recreation, flood control, and hydropower; impoundments created by dams; and land-use change.

Climatological, streamflow, water-withdrawal, and wastewater-return data were collected during the study to develop the HSPF model. Climatological data included precipitation, air temperature, dew-point temperature, solar radiation, and wind speed. These data were collected at stations at Worcester Regional Airport (KORH) in Worcester, Massachusetts; and T.F. Green Airport (KPVD) in Warwick, Rhode Island. Data from both stations were used for model calibration; data from KORH were used for the northern part of the basin, and data from KPVD were used for the southern part of the basin. Data from these stations were used to calculate potential evapotranspiration by the Jensen-Haise method. Streamflow was measured at eight continuous-record streamflow-gaging stations that are part of the U.S. Geological Survey cooperative stream-gaging network, and at seven new stations installed in 2004 for this study. A continuous streamflow record was computed for the calibration period for the new stations to provide additional information for model calibration and evaluation of model performance.

Water-use data were included in the model to represent the net effect of water use on simulated hydrographs. Consequently, the calibrated values of the hydrologic parameters better represent the hydrologic response of the basin to precipitation. Water-use data compiled for 1996-2001 include municipal and commercial/industrial withdrawals, private residential withdrawals, golf-course withdrawals, municipal wastewaterreturn flows, and on-site septic effluent return flows. Irrigation withdrawals for agricultural purposes were not compiled because they are a minor component of total withdrawals in the basin (about 1 percent) and widely distributed as numerous small withdrawals throughout the basin. Total withdrawals from 129 municipal and commercial/industrial withdrawals in the basin averaged about 66 million gallons per day (Mgal/d) for the model-calibration period of 1997-2001. Stream depletion was computed for all time-varying ground-water withdrawals prior to simulation. Total municipal wastewater returns from the 10 wastewater-treatment plants and permitted commercial 
facilities averaged about $54 \mathrm{Mgal} / \mathrm{d}$ for the period. Withdrawals from private wells in areas with public sewers and returns from on-site septic systems in areas with public-water supplies represent net transfers of water in the basin. These transfers were much lower than municipal withdrawals and returns, but they were simulated to represent water use comprehensively in the model. The model parameter DEEPFR was used to represent ground-water infiltration into municipal sewers in the basin.

The HSPF model simulates runoff from precipitation and potential-evapotranspiration time-series data. Processes simulate the transport and fate of water for hydrologic response units (HRUs) and stream reaches (RCHRES) that define the hydrologic characteristics of the basin. The Blackstone River Basin was represented by HRUs composed of 17 pervious areas (PERLNDs), established from combinations of surficial geology, land-use classes, and the distribution of public water and public sewer systems, and 2 impervious areas (IMPLNDs). Wetlands were combined with open water and simulated as stream reaches that receive runoff from surrounding pervious and impervious areas. This approach was taken to achieve greater flexibility in calibrating evapotranspiration losses from wetlands during the growing season. The basin was segmented into 50 reaches to represent junctions at tributaries, major lakes and reservoirs, and drainage areas to streamflowgaging stations. Thirty-six reaches were simulated as stream reaches, and the remaining 14 as lake or reservoir reaches.

The model was calibrated for 1997-2001 to coincide with the land-use and water-use data compiled for the study. Streamflow data from a total of 15 streamflow-gaging stations were used to evaluate model performance across the watershed. Four long-term streamflow-gaging stations (Nipmuc River near Harrisville, Rhode Island [station no. 0111300]; Quinsigamond River at North Grafton, Massachusetts [station no. 0110000]; Branch River at Forestdale, Rhode Island [station no. 01111500]; and Blackstone River at Woonsocket, Rhode Island [station no. 01112500]) that monitor flow at 3.3, 5.4, 19, and 88 percent of the total basin area, respectively, provided the primary model-calibration points. Hydrographs, scatter plots, and flow-duration curves of observed and simulated discharges, along with various model-fit statistics, indicated that the model performed well over a range of hydrologic conditions and time scales. For example, the total runoff volume for the calibration period simulated at the Nipmuc River near Harrisville, Rhode Island; Quinsigamond River at North Grafton, Massachusetts; Branch River at Forestdale, Rhode Island; and Blackstone River at Woonsocket, Rhode Island streamflow-gaging stations differed from the observed runoff volume by $-8.6,3.9,-4.7$, and -5.3 percent, respectively. The Nash-Sutcliffe coefficient for daily mean flows, a goodness-of-fit measure that represents the amount of the variance in the observed flow explained by the model, ranged from 0.61 to 0.78 at these stations. The errors between the observed and simulated mean daily streamflows for the calibration period were within 10 percent at 12 stations, 15 percent at 2 stations, and 25 percent at 1 station.

Simulated flow components for mean annual water budgets indicate that active ground-water flow was about 93 percent of the discharge from PERLNDs overlying sand and gravel and 34 percent of the discharge from PERLNDs overlying till. Interflow was about 7 percent of the discharge from PERLNDs overlying sand and gravel and 56 percent of the discharge from PERLNDs overlying till. Surface runoff was less than 0.1 percent from PERLNDs overlying sand and gravel and 10 percent of the discharge from PERLNDs overlying till. All discharge to streams from IMPLNDs was from surface runoff. Evapotranspiration losses per unit area were mainly from lower-zone storage in PERLNDs overlying sand and gravel and were more equally distributed between upper-zone and lower-zone storage in PERLNDs overlying till. The simulated mean annual runoff from the basin was 23.1 inches (in.) for 1997-2001, of which about 44 percent (10.1 in.) was from forested areas overlying till, and about 11 percent (2.5 in.) was from forest overlying sand and gravel. Forested areas also accounted for about 63 percent of the mean annual evapotranspiration loss of $19.5 \mathrm{in}$. from the basin. Overall, the hydrologic response of the extensive forested areas overlying till exerts a strong influence on the basin water budget. The simulated hydrologic response of medium- to low-density residential development, one of the largest and fastest growing land uses in the basin, is similar to forested areas. Because model calibration and performance reflect the combined response of all the HRUs used to represent the basin, simulation results from analyses in which one type of HRU is changed to another have a high degree of uncertainty.

Numerical watershed models necessarily simplify the complex processes and physical characteristics of a basin. Consequently, there are limitations to the types of questions that can be addressed by the model. Nonetheless, the model can be used effectively to address many water-resource management questions, provided that the limitations and uncertainties are considered. The assumptions, estimation procedures, and data used to develop and calibrate the model, and the possible applicability of alternative model structures and parameter values should be considered when evaluating the model and using its results for water-management decisions.

\section{Acknowledgments}

The authors thank USGS employees John Eggleston for project management and the initial stages of the development of the HSPF model, Lora Barlow and Emily Wild for assistance with water-use data collection and management, Andrew Massey and Tomas Smieszek for assistance with HSPF model development and report preparation, Lance Ostiguy for guidance on GIS analysis, and Douglas Moyer and Stacey Archfield for colleague reviews of the report. Support was also provided by the USGS data-collection staff for streamflow-gaging station installation and maintenance, and by the USGS publications staff for report preparation. Student interns William Hansen, Sarah Lovell, and Rebecca Batchelder are thanked for assistance with data acquisition and processing. The authors thank the Central Massachusetts Regional 
Planning Commission for assistance with GIS information on public water and public sewer systems, and the Massachusetts Department of Environmental Protection and Rhode Island Department of Environmental Management for assistance with procuring municipal water withdrawal and wastewater return data. The authors also thank the managers of municipal water supply and sewer systems in numerous towns in the basin for data, engineering drawings and reports, and explanations of water-supply and wastewater-disposal infrastructures.

\section{References Cited}

Alley, W.M., and Veenhuis, J.E., 1983, Effective impervious area in urban runoff modeling: Journal of Hydraulic Engineering, v. 109, no. 2, p. 313-319.

Arcement, G.J., Jr., and Schneider, V.R., 1989, Guide for selecting Manning's roughness coefficients for natural channels and flood plains: U.S. Geological Survey WaterSupply Paper 2339, 38 p.

Barlow, L.K., 2003, Estimated water use and availability in the lower Blackstone River basin, Northern Rhode Island and South-Central Massachusetts, 1995-1999: U.S. Geological Survey Water-Resources Investigations Report 03-4190, 75 p.

Barlow, P.M., 2000, Documentation of computer program STRMDEPL-A program to calculate streamflow depletion by wells using analytical solutions, in Zarriello, P.J., and Ries, K.G., III, 2000, A precipitation runoff model for the analysis of the effects of water withdrawals on streamflow, Ipswich River Basin, Massachusetts: U.S. Geological Survey Water-Resources Investigations Report 00-4029, 99 p.

Bicknell, B.R., Imhoff, J.C., Kittle, J.L., Jr., Jobes, T.H., and Donigian, A.S., Jr., 2000, Hydrological Simulation Program- FORTRAN User's manual for release 12: Mountain View, Calif., AQUA TERRA Consultants, variously paged.

Camp, Dresser, and McKee, 2001, Upper Blackstone Water Pollution Abatement District, Regional wastewater treatment facilities plan: Boston, Mass., October 2001, variously paged.

Coon, W.F., 1998, Estimation of roughness coefficients for natural stream channels with vegetated banks: U.S. Geological Survey Water-Supply Paper 2441, 133 p.

Craft, P.A., Horn, M.A., and Medalie, Laura, 1990, Estimated withdrawals and use of freshwater in Rhode Island, 1990: U.S. Geological Survey Water-Resources Investigations Report 93-4150, 1 pl.

Crowe, C.T., Elger, D.F., and Roberson, J.A., 2001, Engineering fluid mechanics, $7^{\text {th }}$ ed.: Wiley, 768 p.
Denny, C.S., 1982, Geomorphology of New England: U.S. Geological Survey Professional Paper 1208, 18 p.

Doherty, J., 2003, PEST surface water utilities-Watermark Numerical Computing: University of Idaho, unpublished report, variously paged.

Donigian, A.S., Imhoff, J.C., Bricknell, B.R., Kittle, J.L., Jr., 1984, Application guide for Hydrological Simulation Program-FORTRAN (HSPF): Athens, Georgia, U.S. Environmental Protection Agency-600/3-84-065, Environmental Research Laboratory, 177 p.

Federal Emergency Management Agency, 1994, Water control infrastructure, national inventory of dams-1993-94: CD-ROM.

Flynn, K.M., Hummel, P.R., Lumb, A.M., and Kittle, J.L. Jr., 1995, User's manual for ANNIE, version 2-A computer program for interactive hydrologic data management: U.S. Geological Survey Water-Resources Investigations Report 95-4085, $211 \mathrm{p}$.

Fread, D.L., 1993, Flow routing, in, Maidment, D.R., ed., Handbook of hydrology: New York, New York, McGrawHill, Inc., variously paged.

Friesz, P.J., 2004, Delineation of areas contributing recharge to selected public-supply wells in glacial valley-fill and wetland settings, Rhode Island: U.S. Geological Survey Scientific Investigations Report 2004-5070, 57 p.

Frimpter, M.H., 1974, Ground-water management Blackstone, Moshassuck, and Woonasquatucket River Basins, Massachusetts and Rhode Island, Section 3.03: U.S. Geological Survey Open-File Report 74-1034, variously paged.

Hirsch, R.M., 1982, A comparison of four streamflow record extension techniques: Water Resources Research, v. 18, no. 4 , p. 1081-1088.

Horn, M.A., Craft, P.A., and Bratton, Lisa, 1994, Estimation of water withdrawal and distribution, water use, and wastewater collection and return flow in Cumberland, Rhode Island, 1988: U.S. Geological Survey Water-Resources Investigations Report 93-4023, 54 p.

Izbicki, J.A., 2000, Water resources of the Blackstone River basin, Massachusetts: U.S. Geological Survey WaterResources Investigations Report 93-4167, 1 pl., 115 p.

Jensen, M.E., and Haise, H.R., 1963, Estimating evapotranspiration from solar radiation: Proceedings of the American Society of Civil Engineers, Journal of Irrigation and Drainage, v. 89, no. IR4, p. 15-41.

Johnston, H.E., and Dickerman, D.C., 1974a, Availability of ground water in the Branch River basin, Providence County, Rhode Island: U.S. Geological Survey Water-Resources Investigations Report 18-74, 39 p. 
Johnston, H.E., and Dickerman, D.C., 1974b, Availability of ground water in the Blackstone River area, Rhode Island and Massachusetts: U.S. Geological Survey WaterResources Investigations Report 4-74, 1 plate.

Johnston, H.E., and Dickerman, D.C., 1974c, Geologic and hydrologic data for the Blackstone River area, Rhode Island: Rhode Island Water Resources Coordinating Board Hydrologic Bulletin 7, 42 p., 1 pl., scale 1:24,000.

Johnson, K.E., 1962, Ground-water map of Rhode Island parts of the Attleboro, Blackstone, Franklin, Oxford, and Uxbridge quadrangles: Rhode Island Water Resources Coordinating Board, GWM-19.

Kittle, J.L., Jr., Lumb, A.M., Hummel, P.R., Duda, P.A., and Gray, M.H., 1998, A tool for the analysis of model simulation scenarios for watersheds (GenScn): U.S. Geological Survey Water-Resources Investigations Report 98-4134, $152 \mathrm{p}$.

Korzendorfer, B.A., and Horn, M.A., 1995, Estimated water use in the New England States, 1990: U.S. Geological Survey Water-Resources Investigations Report 94-4252, 21 p.

Krejmas, B.E., and Wandle, S.W., 1982, Drainage divides, Massachusetts-Blackstone and Thames River basins: U.S. Geological Survey Open-File Report 82-631, variously paged.

Lang, S.M., 1961, Appraisals of ground-water reservoir areas in Rhode Island: Rhode Island Water Resources Coordinating Board Geological Bulletin 11, 38 p., 5 pl.

Legates, D.R., and McCabe, G.J., Jr., 1999, Evaluating the use of "goodness-of-fit" measures in hydrologic and hydroclimatic model validation: Water Resources Research, v. 35, no. 1 , p. 233-241.

Love, J.T., and Donigian, A.S., Jr., 2002, The Connecticut watershed model-Model development, calibration, and validation-Presented at WEF-Watershed 2002, February 23-27, 2002: Ft. Lauderdale, Fla.

Lumb, A.M., McCammon, R.B., Kittle, J.L., Jr., 1994, User's manual for an expert system (HSPEXP) for calibration of the Hydrological Simulation Program-FORTRAN: U.S. Geological Survey Water-Resources Investigations Report 94-4168, 102 p.

Massachusetts Department of Environmental Management, 1985, Blackstone River basin-Inventory and analysis of current and projected water uses: Pub. no. 14069-84-500-685-C.R., 83 p.

Massachusetts Department of Environmental Management, 1991, v. 1, Blackstone River basin-Inventory and analysis of current and projected water uses: Pub. no. 16, 623-137100-3-91-C.R., 126 p.
Massachusetts Department of Fisheries and Wildlife, 2004: Accessed 2004 at http://www.mass.gov/dfwele/dfw/dfw_ pond.htm/.

Massachusetts Geographic Information System, 2003, Data layers and metadata: Accessed periodically 2003-2005 at http://www.state.ma.us/mgis/massgis.htm

Melvin, R.L., de Lima, Virginia, and Stone, B.D., 1992a, The stratigraphy and hydraulic properties of tills in southern New England: U.S. Geological Survey Open-File Report 91-481, 53 p.

Melvin, R.L., Stone, B.D., Stone, J.R., and Trask, N.J., 1992b, Hydrogeology of thick till deposits in Connecticut: U.S. Geological Survey Open-File Report, 92-43, 43 p.

National Park Service, 2005, John H. Chaffee Blackstone River Valley National Heritage Corridor-History: Accessed November 18, 2005, at http://www.nps.gov/blac/ discover/history.htm/.

Randall, A.D., Francis, R.M, Frimpter, M.H., and Emery, J.M., 1988, Region 19, Northeastern Appalachians, in Back, W. Rosenshein, J.S., and Seaber, P.R., eds., Hydrogeology: Boulder, Colorado, Geological Society of America, The Geology of North America, v. O-2, p. 177-187.

Regan, R.S., and Schaffranek, R.W., 1985, A computer program for analyzing channel geometry: U.S. Geological Survey Water-Resources Investigations Report 85-4335, 40 p.

Rhode Island Department of Administration, Division of Planning, 1988, Water supply policies for Rhode Island, State guide plan element 721 (Parts 1 and 2): Providence, R.I., Report no. 61, variously paged.

Rhode Island Department of Administration, Division of Planning, 1991, Water supply plan for Rhode Island, State guide plan element 722: Providence, R.I., Report no. 77, variously paged.

Rhode Island Geographic Information System, 2003, Data layers and metadata: Accessed periodically 2003-2005, at http://www.edc.uri.edu/rigis/.

Rosenberry, D.O., Stannard, D.I., Winter, T.C., and Martinez, M.L., 2004, Comparison of 13 equations for determining evapotranspiration from a prairie wetland, Cottonwood Lake area, North Dakota, USA: Wetlands, v. 24, no. 3, p. 483-497.

Searcy, J.K., 1959, Flow-duration curves: U.S. Geological Survey Water-Supply Paper 1542-A, 33 p.

Socolow, R. S., Comeau, L.Y., and Murino D., 2005, Water resource data Massachusetts and Rhode Island water year 2004: U.S. Geological Survey Water-Data Report MA-RI-04-1, $310 \mathrm{p}$. 
U.S. Census Bureau, 2004a, 2000 Census Boundary FilesCensus Blocks: Digital data accessed February 9, 2004, at http://arcdata.esri.com/data/tiger2000/tiger_download.cfm

U.S. Census Bureau, 2004b, 2000 Census of Population and Housing (SF1): Digital data accessed February 9, 2004, at http://arcdata.esri.com/data/tiger2000/tiger_download.cfm

U.S. Census Bureau, 2005, 1990, and 2000 Census data by city and state: Accessed 2005 at http://quickfacts.census. gov/qfd/states/.

U.S. Department of Agriculture, 1999a, 1997 Census of Agriculture, Massachusetts State and County Data, v. 1, Geographic Area Series, Part 21, 321 p.

U.S. Department of Agriculture, 1999b, 1997 Census of Agriculture, Rhode Island State and County Data, v. 1, Geographic Area Series, Part 39, 271 p.

U.S. Environmental Protection Agency, 2000, Estimating hydrology and hydraulic parameters for HSPF, Basins Technical Note 6: EPA-823-R00-012, 32 p.

U.S. Environmental Protection Agency, 2004, Basins: Better Assessment Science Integrating Point and Nonpoint Sources: Accessed 2004 at http://www.epa.gov/ost/basins/.

U.S. Geological Survey, 2005, U.S. Geological Survey National elevation dataset: Accessed 2005 at $h t t p: / / w w w$. ned.usgs.gov/.
Walker, E.H., and Krejmas, B.E., 1986, Water resources of the Blackstone River basin, Massachusetts: U.S. Geological Survey Hydrologic Investigations Atlas HA-682, 2 pl.

Wandle, S.W., and Phipps, A.F., 1984, Gazetteer of hydrologic characteristics of streams in Massachusetts-Blackstone River Basin: U.S. Geological Survey Water-Resources Investigations Report 84-4286, 26 p.

Weinstein, M.J., Kennedy, L.E., and Colonna-Romano, J., 2001, Blackstone River Basin 1998 water quality report, Massachusetts Department of Environmental Protection: Report 51-AC-1, 102 p.

Wright, R.M., Nolan, P.M., Pincumbe, D. Hartman, E., and Viator, O.J., 2001, Blackstone River Initiative-Water quality analysis of the Blackstone River under wet and dry weather conditions: Final Blackstone River Initiative Report, May 2001, variously paged.

Zarriello, P.J., and Bent, G. C., 2004, A precipitation-runoff model for the analysis of the effects of water withdrawals and land-use change on streamflow in the UsquepaugQueen River Basin, Rhode Island: U.S. Geological Survey Scientific Investigations Report 2004-5139, 75 p.

Zarriello, P.J., and Ries, K.G., III, 2000, A precipitation runoff model for the analysis of the effects of water withdrawals on streamflow, Ipswich River Basin, Massachusetts: U.S. Geological Survey Water-Resources Investigation Report 00-4029, 99 p. 


\section{Appendix 1. Hydrological Simulation Program - FORTRAN User Control File Input for Pervious and Impervious Area Parameters}

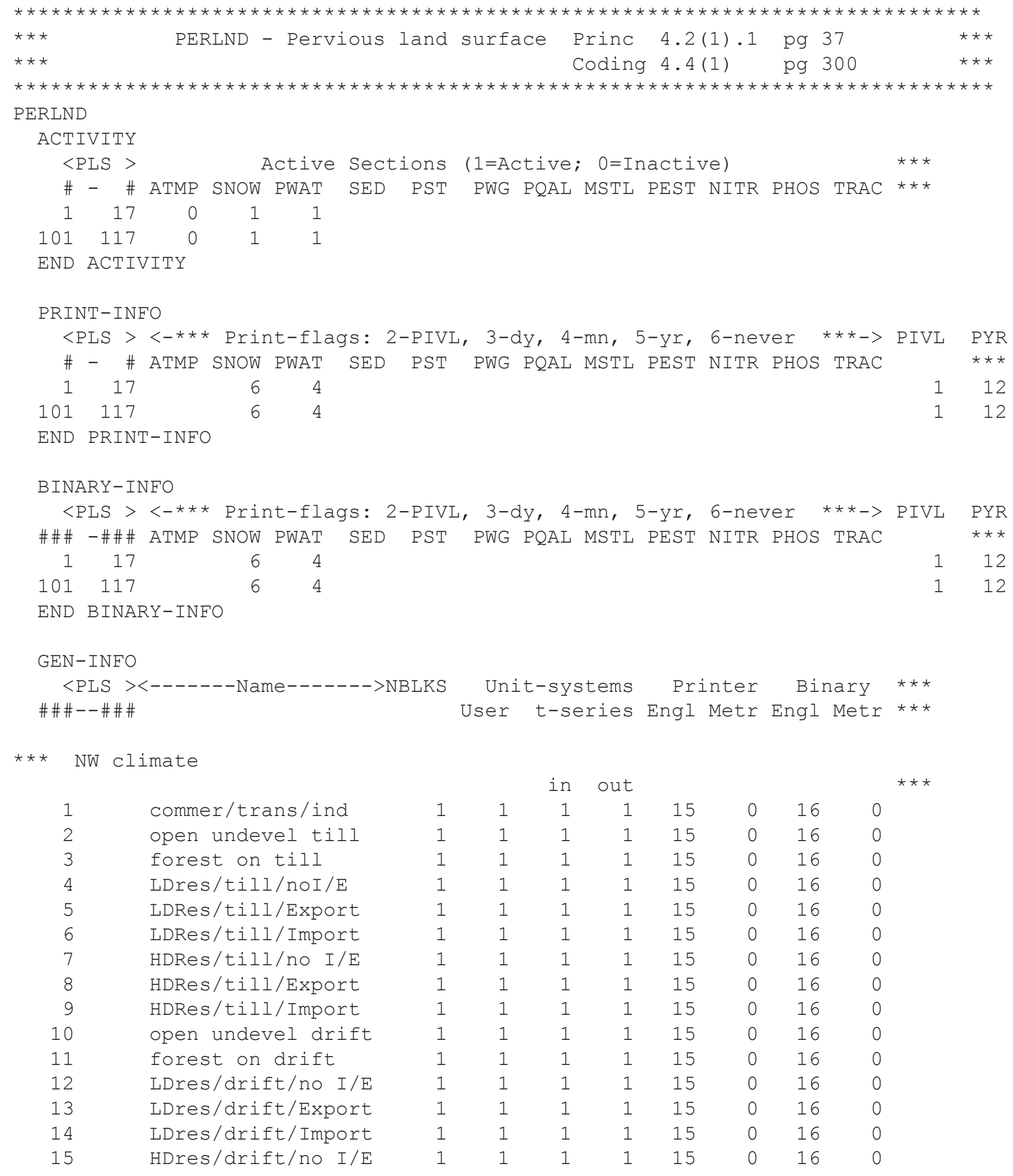


74 A Precipitation-Runoff Model for the Blackstone River Basin

\begin{tabular}{|c|c|c|c|c|c|c|c|c|}
\hline 16 & HDres/drift/Export & 1 & 1 & 1 & 1 & 15 & 0 & 16 \\
\hline 17 & HDres/drift/Import & 1 & 1 & 1 & 1 & 15 & 0 & 16 \\
\hline 101 & commer/trans/ind & 1 & 1 & 1 & 1 & 15 & 0 & 16 \\
\hline 102 & open undevel till & 1 & 1 & 1 & 1 & 15 & 0 & 16 \\
\hline 103 & forest on till & 1 & 1 & 1 & 1 & 15 & 0 & 16 \\
\hline 104 & LDres/till/noI/E & 1 & 1 & 1 & 1 & 15 & 0 & 16 \\
\hline 105 & LDRes/till/Export & 1 & 1 & 1 & 1 & 15 & 0 & 16 \\
\hline 106 & LDRes/till/Import & 1 & 1 & 1 & 1 & 15 & 0 & 16 \\
\hline 107 & HDRes/till/no I/E & 1 & 1 & 1 & 1 & 15 & 0 & 16 \\
\hline 108 & HDRes/till/Export & 1 & 1 & 1 & 1 & 15 & 0 & 16 \\
\hline 109 & HDRes/till/Import & 1 & 1 & 1 & 1 & 15 & 0 & 16 \\
\hline 110 & open undevel drift & 1 & 1 & 1 & 1 & 15 & 0 & 16 \\
\hline 111 & forest on drift & 1 & 1 & 1 & 1 & 15 & 0 & 16 \\
\hline 112 & LDres/drift/no I/E & 1 & 1 & 1 & 1 & 15 & 0 & 16 \\
\hline 113 & LDres/drift/Export & 1 & 1 & 1 & 1 & 15 & 0 & 16 \\
\hline 114 & LDres/drift/Import & 1 & 1 & 1 & 1 & 15 & 0 & 16 \\
\hline 115 & HDres/drift/no I/E & 1 & 1 & 1 & 1 & 15 & 0 & 16 \\
\hline 116 & HDres/drift/Export & 1 & 1 & 1 & 1 & 15 & 0 & 16 \\
\hline 117 & HDres/drift/Import & 1 & 1 & 1 & 1 & 15 & 0 & 16 \\
\hline
\end{tabular}

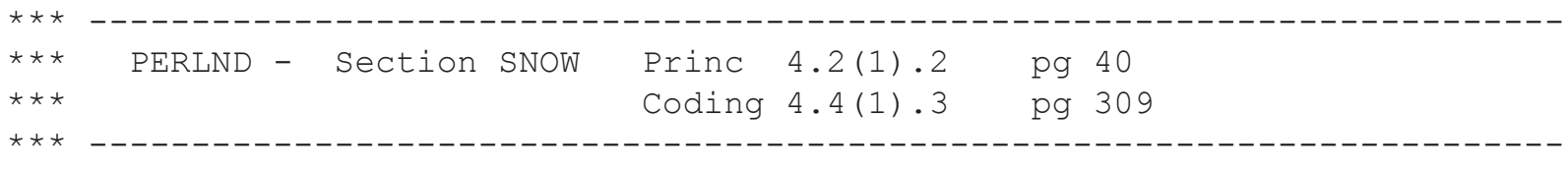

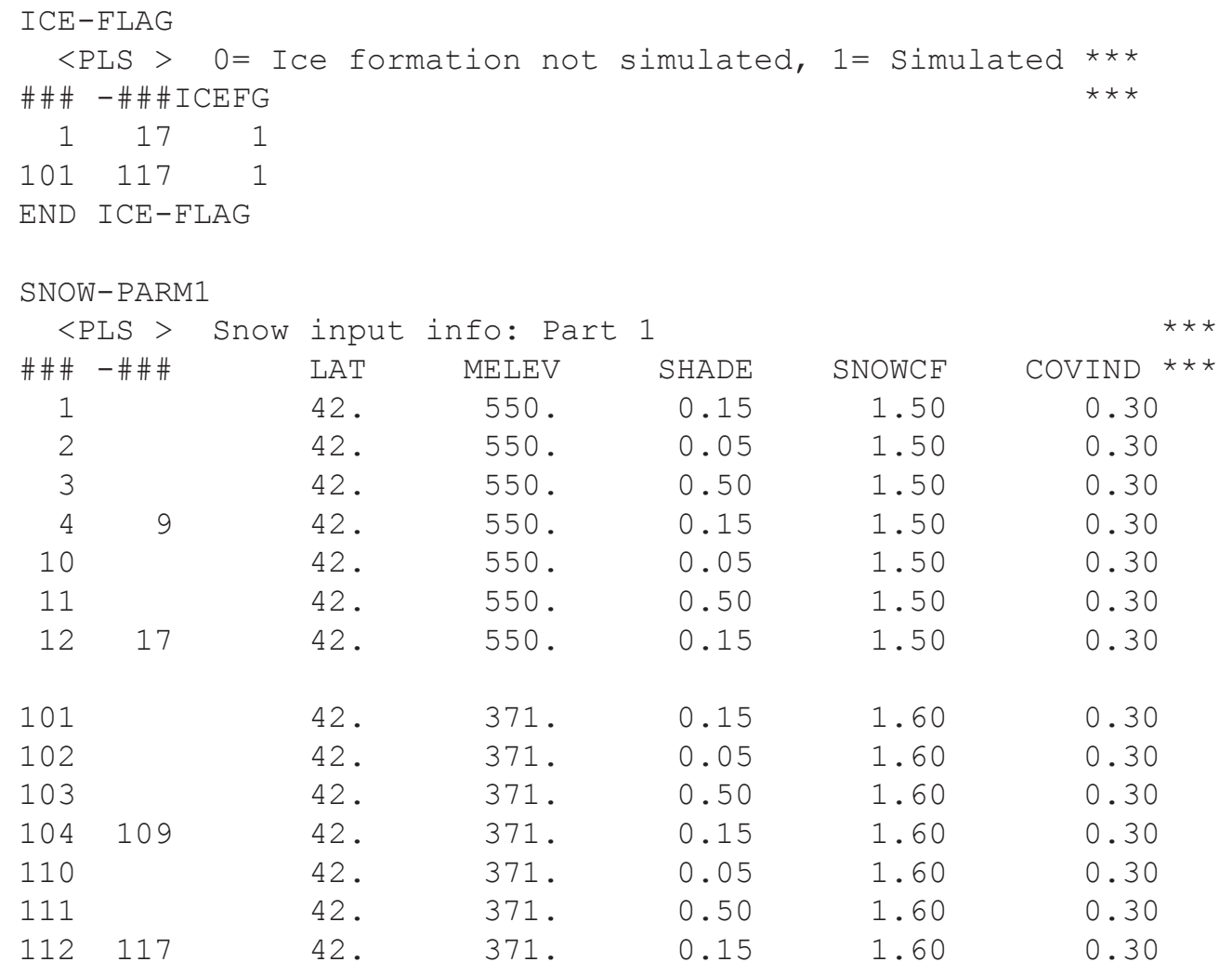

END SNOW-PARMI 


\begin{tabular}{|c|c|c|c|c|c|c|c|c|}
\hline \multicolumn{9}{|c|}{ SNOW-PARM2 } \\
\hline$<$ & $\mathrm{LSS}>$ & Snow input & info: Part & 2 & & & & $\star \star \star$ \\
\hline \#\#\# & -\#\#\# & RDCSN & TSNOW & SNOEVP & CCFACT & MWATER & MGMELT & $\star \star \star$ \\
\hline 1 & 3 & 0.15 & 32 & 0.15 & 1.00 & 0.03 & 0.0100 & \\
\hline 4 & 9 & 0.15 & 32 . & 0.15 & 1.00 & 0.03 & 0.0100 & \\
\hline 10 & & 0.15 & 32. & 0.15 & 1.00 & 0.03 & 0.0100 & \\
\hline 11 & & 0.15 & 32 . & 0.15 & 1.00 & 0.03 & 0.0100 & \\
\hline 12 & 17 & 0.15 & 32 . & 0.15 & 1.00 & 0.03 & 0.0100 & \\
\hline 101 & 103 & 0.15 & 32 . & 0.15 & 1.00 & 0.03 & 0.0100 & \\
\hline 104 & 109 & 0.15 & 32 . & 0.15 & 1.00 & 0.03 & 0.0100 & \\
\hline 110 & & 0.15 & 32 . & 0.15 & 1.00 & 0.03 & 0.0100 & \\
\hline 111 & & 0.15 & 32 . & 0.15 & 1.00 & 0.03 & 0.0100 & \\
\hline 112 & 117 & 0.15 & 32 . & 0.15 & 1.00 & 0.03 & 0.0100 & \\
\hline
\end{tabular}

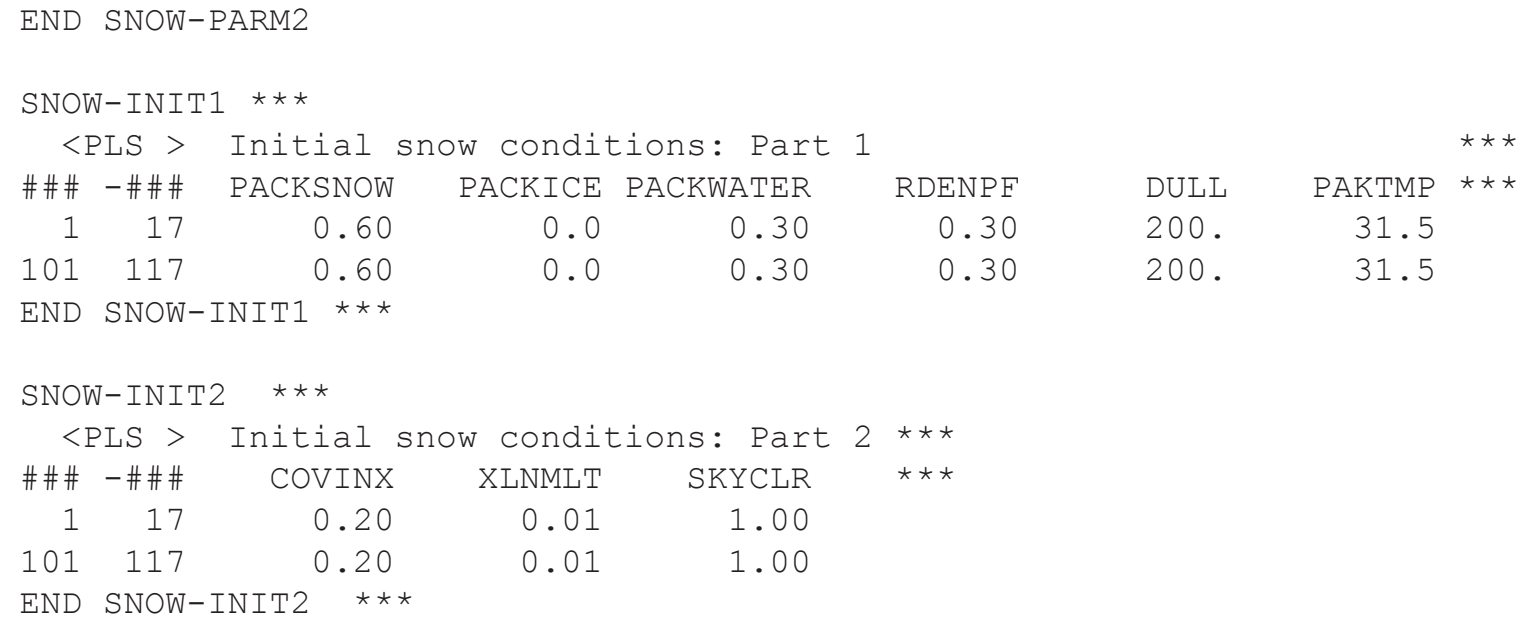




\begin{tabular}{|c|c|c|c|c|c|c|c|c|}
\hline \multicolumn{9}{|c|}{ PWAT-PARM2 } \\
\hline \multicolumn{9}{|c|}{$\langle\mathrm{PLS}>\star \star \star \quad \mathrm{PWATE}$} \\
\hline \# \# \# & -\#\#\# & $\star \star \star F O R E S T$ & LZSN & INFILT & LSUR & SLSUR & KVARY & AGWRC \\
\hline & & $\star \star \star$ (none) & $(i n)$ & (in/hr) & $(f t)$ & (none) & (1/in) & (1/in) \\
\hline 1 & & 0.010 & 3.40 & 0.020 & 100 . & 0.044 & 1.70 & 0.986 \\
\hline 2 & & 0.020 & 4.50 & 0.044 & 300 . & 0.065 & 1.70 & 0.994 \\
\hline 3 & & 0.500 & 4.50 & 0.046 & 400 & 0.077 & 1.70 & 0.994 \\
\hline 4 & 6 & 0.050 & 4.50 & 0.044 & 300 . & 0.067 & 1.70 & 0.992 \\
\hline 7 & 9 & 0.030 & 3.60 & 0.024 & 200. & 0.057 & 1.70 & 0.986 \\
\hline 10 & & 0.020 & 7.40 & 0.541 & 300 . & 0.051 & 0.70 & 0.998 \\
\hline 11 & & 0.500 & 7.40 & 0.571 & 500 & 0.065 & 0.70 & 0.998 \\
\hline 12 & 14 & 0.050 & 7.40 & 0.521 & 300 . & 0.067 & 0.70 & 0.994 \\
\hline 15 & 17 & 0.030 & 6.60 & 0.471 & 200 & 0.057 & 0.70 & 0.992 \\
\hline 101 & & 0.010 & 3.40 & 0.020 & 100 & 0.044 & 1.70 & 0.986 \\
\hline 102 & & 0.020 & 4.50 & 0.044 & 300 . & 0.065 & 1.70 & 0.994 \\
\hline 103 & & 0.500 & 4.50 & 0.046 & 400 & 0.077 & 1.70 & 0.994 \\
\hline 104 & 106 & 0.050 & 4.50 & 0.044 & 300 . & 0.067 & 1.70 & 0.992 \\
\hline 107 & 109 & 0.030 & 3.60 & 0.024 & 200 & 0.057 & 1.70 & 0.986 \\
\hline 110 & & 0.020 & 7.40 & 0.541 & 300 . & 0.051 & 0.70 & 0.998 \\
\hline 111 & & 0.500 & 7.40 & 0.571 & 500. & 0.065 & 0.70 & 0.998 \\
\hline 112 & 114 & 0.050 & 7.40 & 0.521 & 300 . & 0.067 & 0.70 & 0.994 \\
\hline 115 & 117 & 0.030 & 6.60 & 0.471 & 200 . & 0.057 & 0.70 & 0.992 \\
\hline
\end{tabular}

\begin{tabular}{|c|c|c|c|c|c|c|c|c|}
\hline \multicolumn{9}{|c|}{ PWAT-PARM3 } \\
\hline \#\#\# & -\#\#\# & $\star * \star$ PETMAX & PETMIN & INFEXP & INEILD & DEEPFR & BASETP & AGWETP \\
\hline 1 & & 40 & 35 & 2.0 & 2.0 & 0.35 & 0.00 & 0.000 \\
\hline 2 & 3 & 40 & 35 . & 2.0 & 2.0 & 0.00 & 0.00 & 0.000 \\
\hline 4 & 5 & 40. & 35 . & 2.0 & 2.0 & 0.28 & 0.00 & 0.000 \\
\hline 6 & & 40. & 35 . & 2.0 & 2.0 & 0.00 & 0.00 & 0.000 \\
\hline 7 & 8 & 40. & 35 . & 2.0 & 2.0 & 0.45 & 0.00 & 0.000 \\
\hline 9 & 11 & 40. & 35. & 2.0 & 2.0 & 0.00 & 0.00 & 0.000 \\
\hline 12 & 13 & 40. & 35. & 2.0 & 2.0 & 0.28 & 0.00 & 0.000 \\
\hline 14 & & 40. & 35 . & 2.0 & 2.0 & 0.00 & 0.00 & 0.000 \\
\hline 15 & 16 & 40. & 35 . & 2.0 & 2.0 & 0.45 & 0.00 & 0.000 \\
\hline 17 & & 40. & 35 . & 2.0 & 2.0 & 0.00 & 0.00 & 0.000 \\
\hline 101 & & 40. & 35. & 2.0 & 2.0 & 0.35 & 0.00 & 0.000 \\
\hline 102 & 103 & 40. & 35. & 2.0 & 2.0 & 0.00 & 0.00 & 0.000 \\
\hline 104 & 105 & 40. & 35 . & 2.0 & 2.0 & 0.28 & 0.00 & 0.000 \\
\hline 106 & & 40. & 35 . & 2.0 & 2.0 & 0.00 & 0.00 & 0.000 \\
\hline 107 & 108 & 40. & 35 . & 2.0 & 2.0 & 0.45 & 0.00 & 0.000 \\
\hline 109 & 111 & 40. & 35. & 2.0 & 2.0 & 0.00 & 0.00 & 0.000 \\
\hline 112 & 113 & 40. & 35 . & 2.0 & 2.0 & 0.28 & 0.00 & 0.000 \\
\hline 114 & & 40. & 35 . & 2.0 & 2.0 & 0.00 & 0.00 & 0.000 \\
\hline 115 & 116 & 40 . & 35 . & 2.0 & 2.0 & 0.45 & 0.00 & 0.000 \\
\hline 117 & & 40. & 35 . & 2.0 & 2.0 & 0.00 & 0.00 & 0.000 \\
\hline
\end{tabular}




\begin{tabular}{|c|c|c|c|c|c|c|c|c|c|c|c|c|c|c|c|}
\hline \multicolumn{16}{|c|}{ PWAT-PARM4 } \\
\hline \multicolumn{2}{|c|}{$* \star \star$ Varied } & \multicolumn{2}{|c|}{ Season Y } & \multicolumn{2}{|r|}{$\mathrm{N}$} & \multicolumn{2}{|c|}{$Y$} & \multirow{2}{*}{\multicolumn{2}{|c|}{$\mathrm{N}$}} & \multirow{2}{*}{\multicolumn{2}{|c|}{$\mathrm{N}$}} & \multirow{2}{*}{\multicolumn{2}{|c|}{ Y }} & $\star \star \star$ & \\
\hline & $\mathrm{PLS}>$ & & \multirow{2}{*}{$\begin{array}{c}\text { PWATER } \\
\text { VCS }\end{array}$} & inpu & ut inf & $=0: P \bar{c}$ & art 4 & & & & & & & $\star \star \star$ & \\
\hline \multicolumn{3}{|c|}{ Flag PARM4 } & & \multicolumn{2}{|c|}{ VUZ } & \multicolumn{2}{|c|}{ VUR } & \multicolumn{2}{|r|}{ VMN } & \multicolumn{2}{|r|}{ VIFW } & \multicolumn{2}{|r|}{ VLE } & $\star \star \star$ & \\
\hline & \multirow{2}{*}{\multicolumn{2}{|c|}{-\#\#\# }} & \multirow{2}{*}{$\begin{array}{c}\text { CEPSC } \\
\text { (in) }\end{array}$} & \multirow{2}{*}{\multicolumn{2}{|c|}{$\begin{array}{l}\text { UZSN } \\
(\text { in) }\end{array}$}} & \multirow{2}{*}{\multicolumn{2}{|c|}{$\begin{array}{c}\text { NSUR } \\
\text { (none) }\end{array}$}} & \multirow{2}{*}{\multicolumn{2}{|c|}{$\begin{array}{l}\text { INTEW } \\
\text { (none) }\end{array}$}} & & IRC & & LZETP & $\star \star \star$ & \\
\hline & & & & & & & & & & & $1 / d a)$ & & none) & $\star \star \star$ & \\
\hline 1 & & & 0.030 & & 0.56 & & 0.200 & & 4.00 & & 0.36 & & 0.20 & & \\
\hline 2 & & & 0.020 & & 0.62 & & 0.250 & & 8.00 & & 0.50 & & 0.40 & & \\
\hline 3 & & & 0.050 & & 0.65 & & 0.230 & & 9.00 & & 0.56 & & 0.70 & & \\
\hline 4 & 6 & & 0.040 & & 0.65 & & 0.210 & & 6.00 & & 0.54 & & 0.40 & & \\
\hline 7 & 9 & & 0.040 & & 0.65 & & 0.210 & & 4.00 & & 0.46 & & 0.30 & & \\
\hline 10 & & & 0.020 & & 0.75 & & 0.250 & & 10.00 & & 0.90 & & 0.40 & & \\
\hline 11 & & & 0.080 & & 0.77 & & 0.230 & & 12.00 & & 0.90 & & 0.70 & & \\
\hline 12 & 14 & & 0.040 & & 0.77 & & 0.210 & & 10.00 & & 0.86 & & 0.40 & & \\
\hline 15 & 17 & & 0.040 & & 0.77 & & 0.210 & & 9.50 & & 0.82 & & 0.30 & & \\
\hline 101 & & & 0.030 & & 0.56 & & 0.200 & & 4.00 & & 0.36 & & 0.20 & & \\
\hline 102 & & & 0.020 & & 0.62 & & 0.250 & & 8.00 & & 0.50 & & 0.40 & & \\
\hline 103 & & & 0.050 & & 0.65 & & 0.230 & & 9.00 & & 0.56 & & 0.70 & & \\
\hline 104 & 106 & & 0.040 & & 0.65 & & 0.210 & & 6.00 & & 0.54 & & 0.40 & & \\
\hline 107 & 109 & & 0.040 & & 0.65 & & 0.210 & & 4.00 & & 0.46 & & 0.30 & & \\
\hline 110 & & & 0.020 & & 0.75 & & 0.250 & & 10.00 & & 0.90 & & 0.40 & & \\
\hline 111 & & & 0.080 & & 0.77 & & 0.230 & & 12.00 & & 0.90 & & 0.70 & & \\
\hline 112 & 114 & & 0.040 & & 0.77 & & 0.210 & & 10.00 & & 0.86 & & 0.40 & & \\
\hline 115 & 117 & & 0.040 & & 0.77 & & 0.210 & & 9.50 & & 0.82 & & 0.30 & & \\
\hline END & PWAT- & -PARM & & & & & & & & & & & & & \\
\hline $\mathrm{MON}-$ & -INTER & RCEP & & & & & & & & & & & & & \\
\hline & onthly & $y$ int & ercept & ion s & storag & ye cap & pacity & & & & & & & $\star \star \star$ & \\
\hline$<\mathrm{E}$ & $\mathrm{PLS}>$ & Onl & y requ & ired & if VC & $S F G=1$ & 1 in $P h$ & WAT-E & PARM1 & & & & & $\star \star \star$ & \\
\hline \#\#\# & -\#\#\# & Int & ercept & ion $\mathrm{s}$ & storag & ye cap & pacity & ats & start & of ea & ach mo & $n t h$ & & $\star \star \star$ & \\
\hline & & JAN & $\mathrm{FEB}$ & MAR & $\mathrm{APR}$ & MAY & JUN & JUL & AUG & SEP & OCT & NOV & $\mathrm{DEC}$ & $\star \star \star$ & \\
\hline 1 & & 0.02 & 0.02 & 0.02 & 0.03 & 0.03 & 0.050 & 0.05 & 0.05 & 0.05 & 0.03 & 0.02 & 0.02 & & \\
\hline 2 & & 0.02 & 0.02 & 0.02 & 0.03 & 0.03 & 0.040 & 0.04 & 0.04 & 0.04 & 0.03 & 0.02 & 0.02 & & \\
\hline 3 & & 0.04 & 0.04 & 0.04 & 0.04 & 0.05 & 0.120 & 0.14 & 0.16 & 0.17 & 0.16 & 0.04 & 0.04 & & \\
\hline 4 & 9 & 0.02 & 0.02 & 0.02 & 0.03 & 0.03 & 0.050 & 0.05 & 0.05 & 0.05 & 0.03 & 0.02 & 0.02 & & \\
\hline 10 & & 0.02 & 0.02 & 0.02 & 0.03 & 0.03 & 0.040 & 0.04 & 0.04 & 0.04 & 0.03 & 0.02 & 0.02 & & \\
\hline 11 & & 0.04 & 0.04 & 0.04 & 0.04 & 0.05 & 0.12 & 0.14 & 0.16 & 0.17 & 0.16 & 0.04 & 0.04 & & \\
\hline 12 & 17 & 0.02 & 0.02 & 0.02 & 0.03 & 0.03 & 0.050 & 0.05 & 0.05 & 0.05 & 0.03 & 0.02 & 0.02 & & \\
\hline 101 & & 0.02 & 0.02 & 0.02 & 0.03 & 0.03 & 0.050 & 0.05 & 0.05 & 0.05 & 0.03 & 0.02 & 0.02 & & \\
\hline 102 & & 0.02 & 0.02 & 0.02 & 0.03 & 0.03 & 0.04 & 0.04 & 0.04 & 0.04 & 0.03 & 0.02 & 0.02 & & \\
\hline 103 & & 0.04 & 0.04 & 0.04 & 0.04 & 0.05 & 0.120 & 0.14 & 0.16 & 0.17 & 0.16 & 0.04 & 0.04 & & \\
\hline 104 & 109 & 0.02 & 0.02 & 0.02 & 0.03 & 0.03 & 0.050 & 0.05 & 0.05 & 0.05 & 0.03 & 0.02 & 0.02 & & \\
\hline
\end{tabular}


$\begin{array}{llllllllllllll}110 & 0.02 & 0.02 & 0.02 & 0.03 & 0.03 & 0.04 & 0.04 & 0.04 & 0.04 & 0.03 & 0.02 & 0.02\end{array}$ $\begin{array}{llllllllllllll}111 & 0.04 & 0.04 & 0.04 & 0.04 & 0.05 & 0.12 & 0.14 & 0.16 & 0.17 & 0.16 & 0.04 & 0.04\end{array}$ $\begin{array}{llllllllllllllll}112 & 117 & 0.02 & 0.02 & 0.02 & 0.03 & 0.03 & 0.05 & 0.05 & 0.05 & 0.05 & 0.03 & 0.02 & 0.02\end{array}$ END MON-INTERCEP

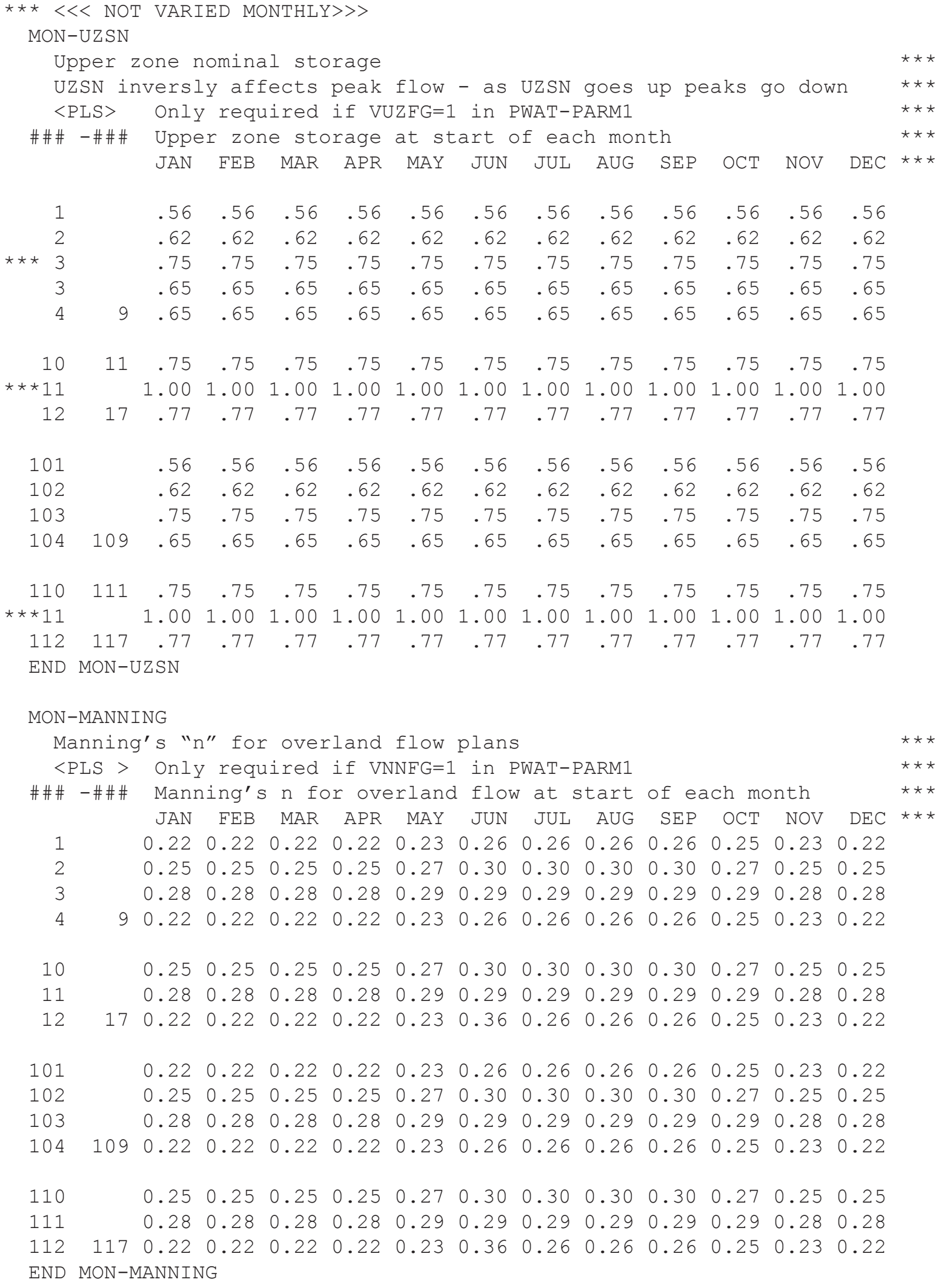




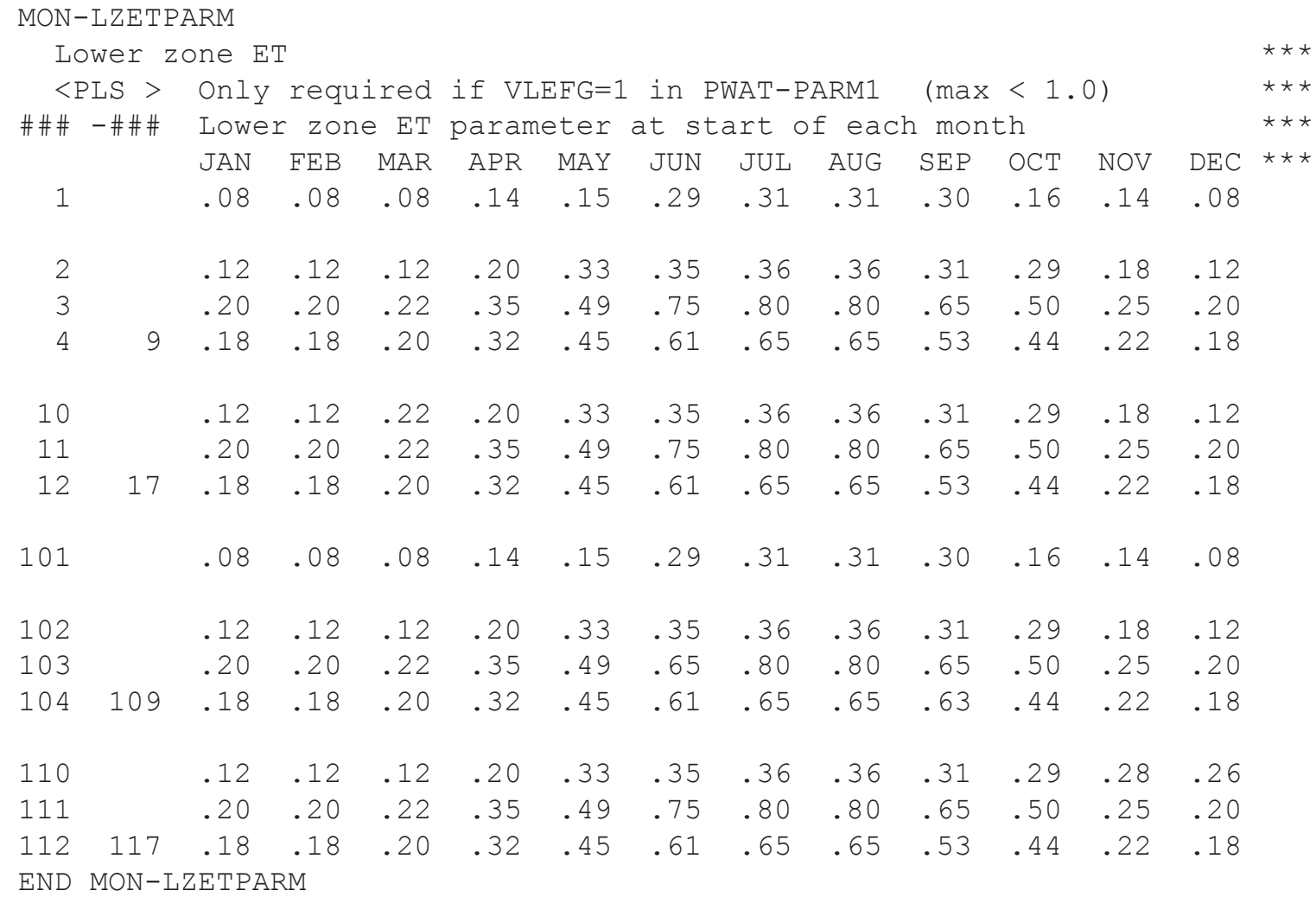

PWAT-STATE1

$\langle\mathrm{PLS}>\star \star \star$ Initial conditions at start of simulation (from Jan. 1998 values in . out file)

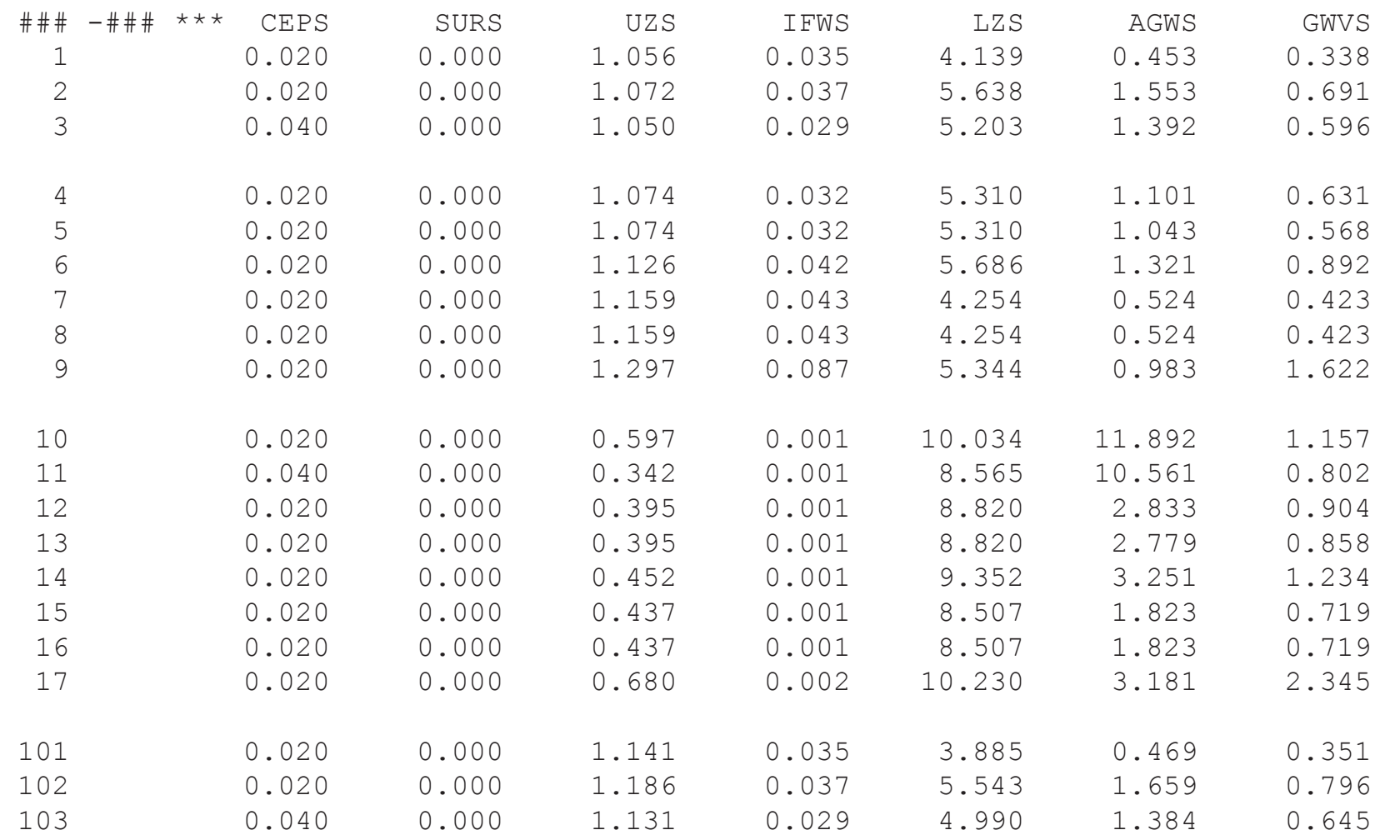




$\begin{array}{lllllllll}104 & 0.020 & 0.000 & 1.166 & 0.032 & 5.132 & 1.153 & 0.694 \\ 105 & 0.020 & 0.000 & 1.166 & 0.032 & 5.132 & 1.082 & 0.624 \\ 106 & 0.020 & 0.000 & 1.234 & 0.042 & 5.545 & 1.416 & 0.968 \\ 107 & 0.020 & 0.000 & 1.275 & 0.043 & 4.126 & 0.561 & 0.453 \\ 108 & 0.020 & 0.000 & 1.275 & 0.043 & 4.126 & 0.561 & 0.453 \\ 109 & 0.020 & 0.000 & 1.390 & 0.087 & 5.265 & 1.088 & 1.650 \\ 110 & 0.020 & 0.000 & 0.504 & 0.001 & 9.671 & 12.115 & 1.407 \\ 111 & 0.040 & 0.000 & 0.261 & 0.001 & 8.093 & 10.464 & 0.914 \\ 112 & 0.020 & 0.000 & 0.336 & 0.001 & 8.535 & 2.867 & 1.078 \\ 113 & 0.020 & 0.000 & 0.336 & 0.001 & 8.535 & 2.804 & 1.024 \\ 114 & 0.020 & 0.000 & 0.386 & 0.001 & 9.067 & 3.342 & 1.424 \\ 115 & 0.020 & 0.000 & 0.372 & 0.001 & 8.234 & 1.877 & 0.861 \\ 116 & 0.020 & 0.000 & 0.372 & 0.001 & 8.234 & 1.877 & 0.861 \\ 117 & 0.020 & 0.000 & 0.588 & 0.002 & 9.972 & 3.496 & 2.557\end{array}$

END PWAT-STATE1

END PERLND

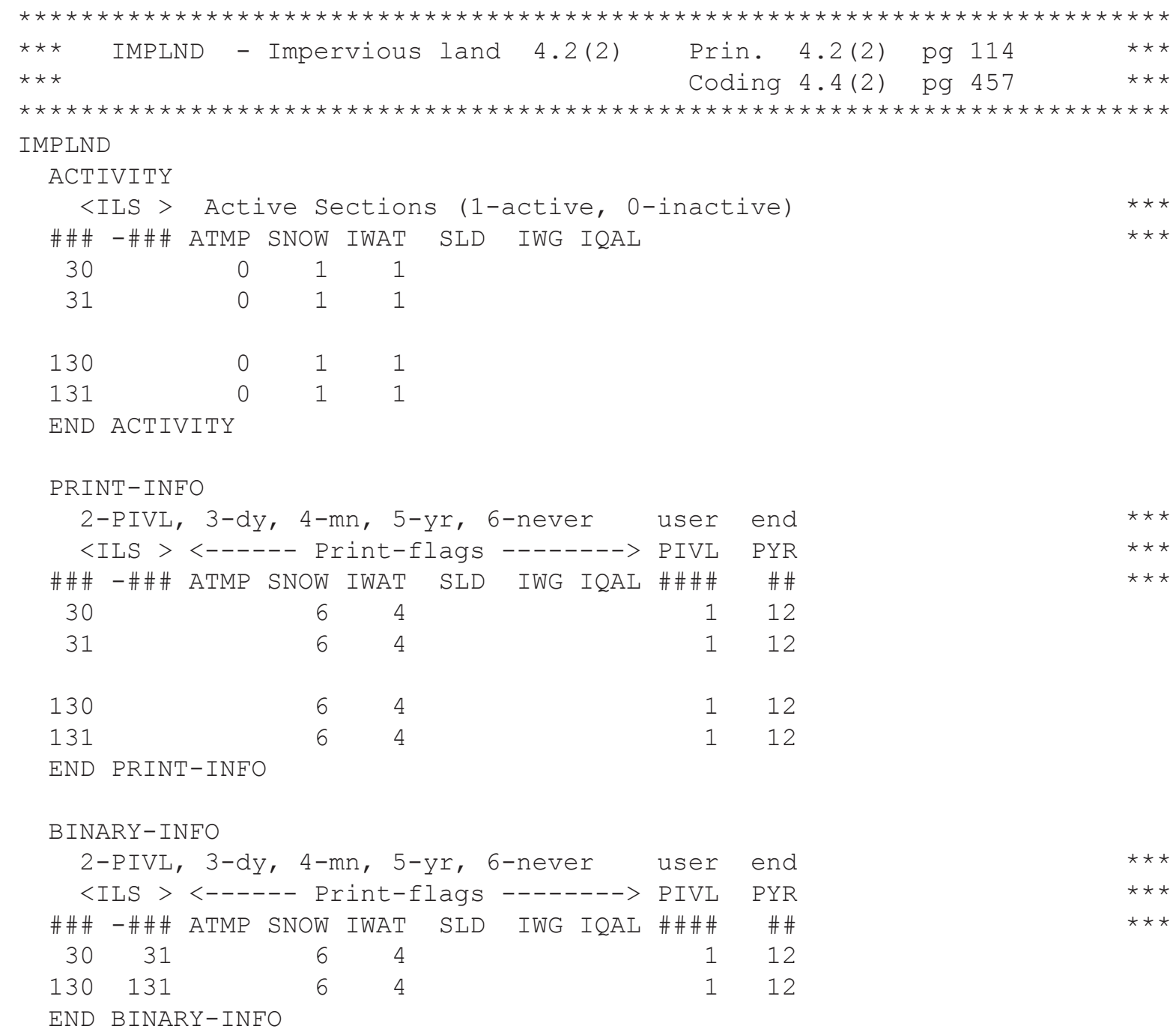


82 A Precipitation-Runoff Model for the Blackstone River Basin

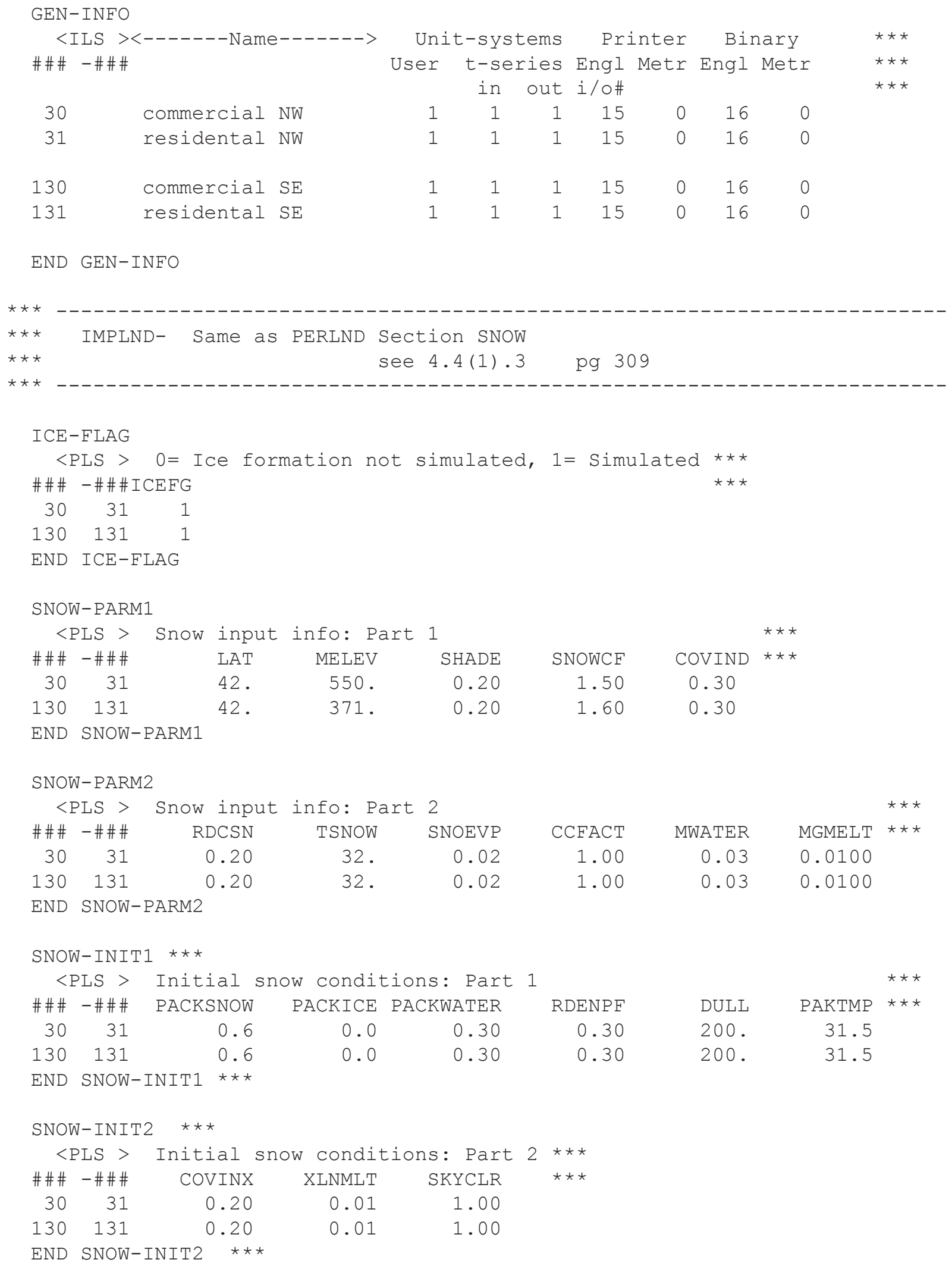




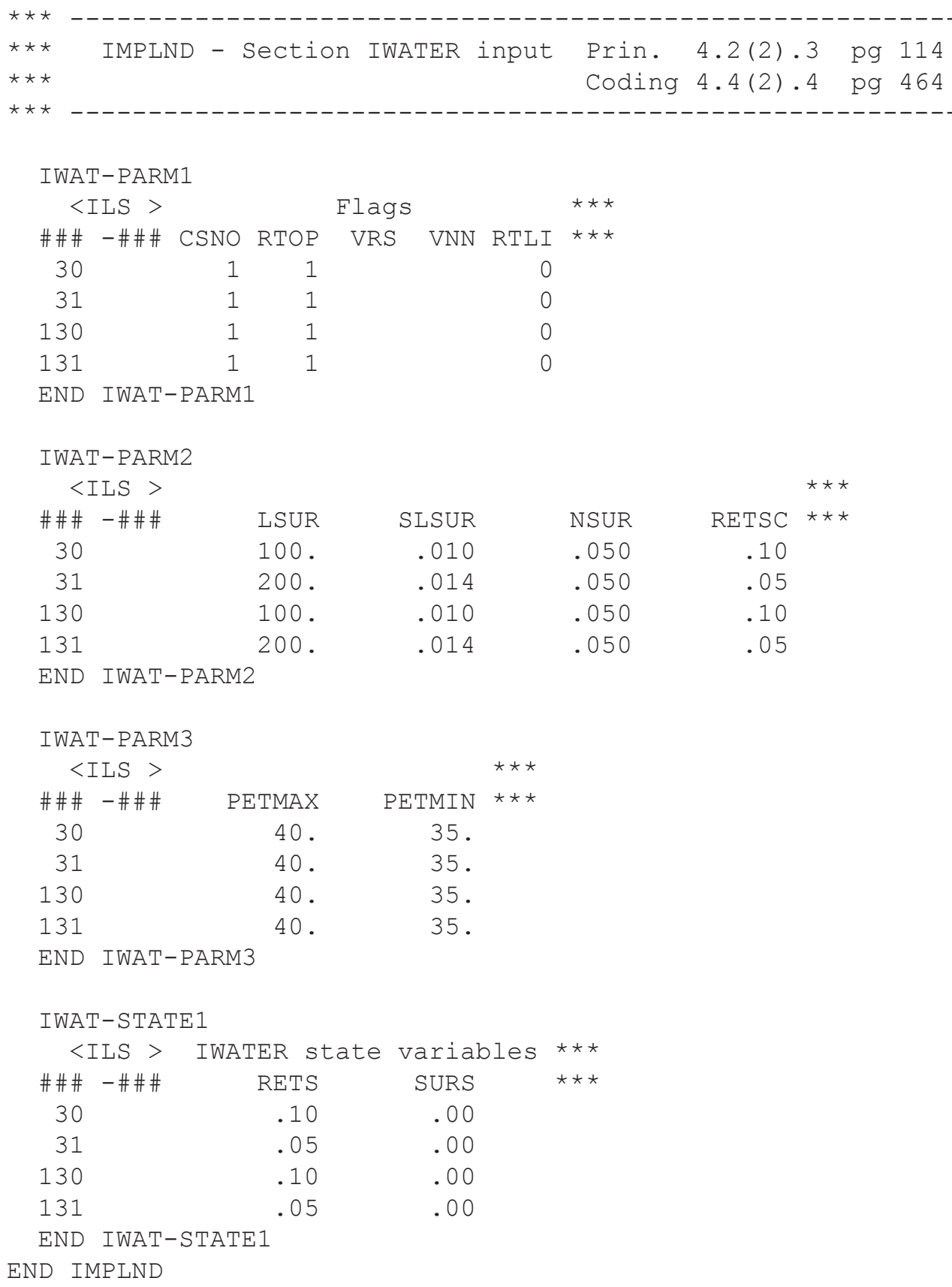

